\title{
REVISTA
}

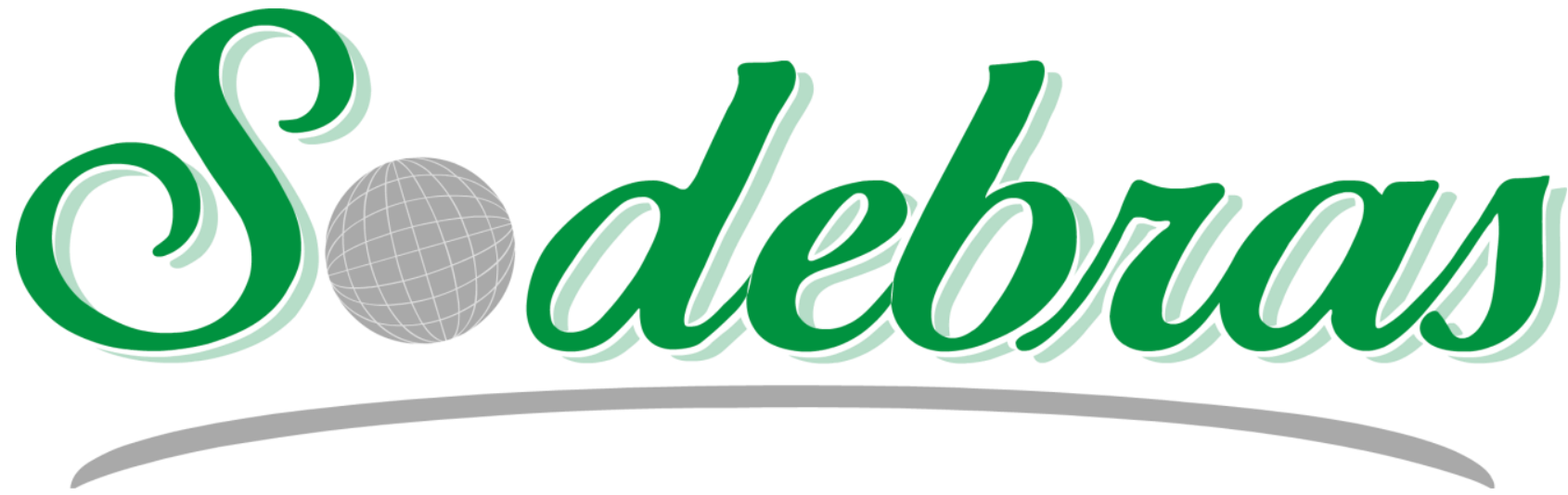

SOLUÇÕES PARA O DESENVOLVIMENTO DO PAÍS 


\title{
ARTIGOS PUBLICADOS
}

\author{
PUBLICAÇÃO MENSAL
}

Nesta edição

\section{O CLUBE DE TROCAS DA ITCP/UNIFAL-MG E A EXTENSÃO UNIVERSITÁRIA: APROXIMAÇÕES E DESDOBRAMENTOS}

THE EXCHANGE CLUB FROM ITCP/UNIFAL-MG AND THE UNIVERSITY EXTENSION PROGRAM: APPROXIMATIONS AND UNFOLDING - Kaio Lucas Da Silva Rosa; Lucas Eduardo Juventino; Dimitri Augusto Da Cunha Toledo; Ana Carolina Guerra

O PACTO NACIONAL PARA A ALFABETIZAÇÃO NA IDADE CERTA COMO AÇÃO INOVADORA PARA O LETRAMENTO DE CRIANÇAS NO BRASIL

THE NATIONAL COVENANT FOR LITERACY IN THE RIGHT AGE AS INNOVATIVE ACTION FOR THE LETTERING OF CHILDREN IN BRAZIL - Márcia Lopes Reis; Amanda Barbosa Gaspar De Lima

EDUCAÇÃO DO CAMPO: A IMPORTÂNCIA DO PROFISSIONAL PEDAGOGO NAS EDUCAÇÃO DO CAMPO

EDUCATION OF THE FIELD: AN IMPORTANCE OF THE PROFESSIONAL PEDAGOGUE IN RURAL EDUCATION - Carlos Luis Pereira; Edson Rodrigues Dos Santos

A PARTICIPAÇÃO SOCIAL NA POLÍTICA DE ASSISTÊNCIA ESTUDANTIL DA UFOP, NA PERSPECTIVA DA GESTÃO SOCIAL

SOCIAL PARTICIPATION IN UFOP STUDENT ASSISTANCE POLICY IN THE PERSPECTIVE OF SOCIAL MANAGEMENT - Priscila Sena Gonçalves; Adilene Gonçalves Quaresma

ASPECTOS RELACIONADOS À ALIMENTAÇÃO DE EDUCANDOS DA EJA DENTRO E FORA DA ESCOLA EMEF "PROF. PEDRO SIMÃO", EM ALEGRE, ESPÍRITO SANTO

FOOD NEED FOR EJA STUDENTS RELATED TO FOOD INSIDE AND OUTSIDE EMEF SCHOOL "PROF. PEDRO SIMÃO", IN ALEGRE, ESPÍRITO SANTO - Manuela Barcelos Martins; Geraldo Moreira Alves; Wanessa Soares Luiz Silva; Rutheneia Alves Santana; Marcus Antonius Da Costa Nunes; Daniel Rodrigues Silva

O TRABALHO DO ENFERMEIRO JUNTO ÀS MULHERES NA COLETA DO EXAME CITOPATOLÓGICO NA UNIDADE DE SAÚDE III - SÃO JOSÉ DO CALÇADO-ES

THE NURSE WORK TOWARD WOMEN IN THE COLLECTION OF THE CYTOPATHOLOGICAL EXAMINATION IN HEALTH UNIT III - SÃO JOSÉ DO CALÇADO-ES - Sara Castilholi Tiradentes Ramalho; Rutheneia Alves Santana; Geraldo Moreira Alves; Julianna Godoi De Souza; Juscelio Abreu Clemente; Roberto Santos Barbieri; Marcus Antonius Da Costa Nunes; Luana Frigulha Guisso; Wanessa Soares Luiz Silva; Bruno Augusto De Rezende; Daniel Rodrigues Silva

AVALIAÇÃO DO ESTRESSE NA TRIPULAÇÃO DE RESGATE AEROMÉDICO

STRESS ANALYSIS OF AEROMEDICAL RESCUE CREW - Luis Fernando Wu; Fernanda Yamashita; Letícia De Oliveira Cardoso; Nick Chang; Rafael Rick Matsuo De Carvalho; Júnia Shizue Sueoka 
PRODUÇÃO DE PÃES E MASSAS FRESCAS EMPREGANDO DIFERENTES PERCENTUAIS DE FARINHA DE CENOURA EM SUBSTITUIÇÃO À FARINHA DE TRIGO

PRODUCTION OF BREADS AND FRESH PASTS BY EMPLOYING DIFFERENT PERCENTAGES OF CARROT FLOUR IN REPLACEMENT OF WHEAT FLOUR - Betina Mariela Barreto; Ana Lúcia Becker Rohlfes; Nádia De Monte Baccar; Liliane Marquardt

ANÁLISE DA RELAÇÃO DA CULTURA MAKER, FABLABS E ROBÓTICA EDUCACIONAL NA EDUCAÇÃO

ANALYSIS OF THE RELATIONSHIP OF CULTURE MAKER, FABLABS AND EDUCATIONAL ROBOTICS IN EDUCATION - Peterson Albuquerque Lobato; Isabella Sampaio Santos; Camila Silva Pereira Jorge; Matheus Guimarães Tanure; Eduardo Manoel De Freitas Jorge; Hugo Saba; André Ricardo Magalhães

OBTENÇÃO, CARACTERIZAÇÃO E AVALIAÇÃO DA ATIVIDADE ANTIMICROBIANA DE FILME POLIMÉRICO DE GELATINA EXTRAÍDA DAS ESCAMAS DE TILÁPIA CONTENDO COMO CARGA O SALICILATO DE COBALTO(II)

OBTAINING, CHARACTERIZATION AND THE ANTIMICROBIAL EVALUATION OF THE POLYMERIC FILM OF GELATIN EXTRACTED FROM THE TILAPIA SCALES CONTAINING COBALT(II) SALICYLATE AS LOAD - Kauani Caldato; Filipe Kialil Da Silva Neves; Gabrielle Cristina Calegari; Vidiany Aparecida Queiroz Santos; Mario Antônio Alves Da Cunha; Leandro Zatta

DESENVOLVIMENTO DE UM SISTEMA AUTOMATIZADO PARA ALIMENTAÇÃO DE LINHAS DE PRODUÇÃO DE RÁDIOS AUTOMOTIVOS INTRÍNSECO À INDUSTRIA 4.0

DEVELOPMENT OF AN AUTOMATED SYSTEM FOR POWER SUPPLY OF AUTOMATIC RADIO PRODUCTION INTRINSIC TO INDUSTRY 4.0 - Erik Tavares Guedes; Manoel S. S. Azevedo; Jandecy Cabral Leite; Arlindo Messias Mendes Da Costa; Geanne Tereza Ferreira Olimpio; Will Ribamar Mendes Almeida

VIABILIDADE DE APLICAÇÃO DE ENERGIA SOLAR PARA GERAÇÃO DE ENERGIA E AQUECIMENTO DE ÁGUA

FEASIBILITY APPLICATION OF SOLAR ENERGY FOR POWER GENERATION AND WATER HEATING Fernando Da Costa Lima; Teofilo Miguel De Souza; Stephanie Caroline Machado Thomaz Da Silva Lima; Pedro Magalhães Sobrinho

DESENVOLVIMENTO DE UM PROGRAMA PARA ESTIMATIVA DE PARÂMETROS LONGITUDINAIS E TRANSVERSAIS DE LINHAS DE TRANSMISSÃO AÉREA EM CORRENTE ALTERNADA

DEVELOPMENT OF A PROGRAM FOR ESTIMATION OF LONGITUDINAL AND TRANSVERSAL PARAMETERS OF ALTERNATE CURRENT OVERHEAD TRANSMISSION LINES - Kaio Cesar Maciel Nascimento; Stefani Carolline Leal De Freitas; Priscila Da Silva Oliveira; Cleiner Da Silva Assis; Alcy Monteiro Junior; Adelicio Maxmiano Sobrinho; Sérgio Manuel Rivera Sanhueza; Marilene Andreia Mantovani

MEDIDAS PARA REDUZIR O CONSUMO DE ENERGIA NO SETOR RESIDENCIAL - UMA REVISÃO

MEASURES FOR REDUCING ENERGY CONSUMPTION IN THE RESIDENTIAL SECTOR - A REVIEW Thamyres Machado David; Teófilo Miguel De Souza; Paloma Maria Silva Rocha Rizol; Marcela Aparecida Guerreiro Machado; Luciano Lizardo De Souza Guimarães

PRODUÇÃO DE SYNGAS E SEU USO NA GERAÇÃO DE ENERGIA: UMA REVISÃO

SYNGAS PRODUCTION AND ITS POWER GENERATION USE: A REVIEW - Diogo Theodoro Lago; Teófilo Miguel De Souza; Luiz Carlos Bevilaqua Dos Santos Reis; João Andrade De Carvalho Júnior

INFLUÊNCIA DA RELAÇÃO DE PRESSÃO E FRAÇÃO DE AR EXTRAÍDA DO COMPRESSOR NO ARREFECIMENTO DAS PÁS DE TURBINAS A GÁS

INFLUENCE OF THE PRESSURE RATIO AND AIR FRACTION EXTRACTED FROM THE COMPRESSOR ON GAS TURBINE BLADES COOLING - Crystiara Paula Santos Da Silva Venâncio; Larissa Rodrigues Marconi; Filipe Arthur Firmino Monhol 
ANTROPOMETRIA E ERGONOMIA COMO FERRAMENTAS DE VANGUARDA PRODUTIVAS NAS INDÚSTRIAS DO FUTURO

ERGONOMICS AND ANTHROPOMETRY AS PRODUCTION VANGUARD TOOLS IN THE INDUSTRIES OF THE FUTURE - Natasha Martins Rodrigues De Jesus; Rafael Soares Souza; Roque Antônio Moura 


\section{Área: Ciências Humanas e Sociais}

\begin{tabular}{|c|c|}
\hline $6-2$ & $\begin{array}{l}\text { O CLUBE DE TROCAS DA ITCP/UNIFAL-MG E A EXTENSÃO UNIVERSITÁRIA: } \\
\text { APROXIMAÇÕES E DESDOBRAMENTOS } \\
\text { THE EXCHANGE CLUB FROM ITCP/UNIFAL-MG AND THE UNIVERSITY } \\
\text { EXTENSION PROGRAM: APPROXIMATIONS AND UNFOLDING } \\
\text { Kaio Lucas Da Silva Rosa; Lucas Eduardo Juventino; Dimitri Augusto Da Cunha } \\
\text { Toledo; Ana Carolina Guerra }\end{array}$ \\
\hline $7-8$ & $\begin{array}{l}\text { O PACTO NACIONAL PARA A ALFABETIZAÇÃO NA IDADE CERTA COMO } \\
\text { AÇÃO INOVADORA PARA O LETRAMENTO DE CRIANÇAS NO BRASIL } \\
\text { THE NATIONAL COVENANT FOR LITERACY IN THE RIGHT AGE AS } \\
\text { INNOVATIVE ACTION FOR THE LETTERING OF CHILDREN IN BRAZIL } \\
\text { Márcia Lopes Reis; Amanda Barbosa Gaspar De Lima }\end{array}$ \\
\hline $7-8$ & $\begin{array}{l}\text { EDUCAÇÃO DO CAMPO: A IMPORTÂNCIA DO PROFISSIONAL PEDAGOGO } \\
\text { NAS EDUCAÇÃO DO CAMPO } \\
\text { EDUCATION OF THE FIELD: AN IMPORTANCE OF THE PROFESSIONAL } \\
\text { PEDAGOGUE IN RURAL EDUCATION } \\
\text { Carlos Luis Pereira; Edson Rodrigues Dos Santos }\end{array}$ \\
\hline $7-8$ & $\begin{array}{l}\text { A PARTICIPAÇÃO SOCIAL NA POLÍTICA DE ASSISTÊNCIA ESTUDANTIL } \\
\text { DA UFOP, NA PERSPECTIVA DA GESTÃO SOCIAL } \\
\text { SOCIAL PARTICIPATION IN UFOP STUDENT ASSISTANCE POLICY IN THE } \\
\text { PERSPECTIVE OF SOCIAL MANAGEMENT } \\
\text { Priscila Sena Gonçalves; Adilene Gonçalves Quaresma }\end{array}$ \\
\hline $7-9$ & $\begin{array}{l}\text { ASPECTOS RELACIONADOS À ALIMENTAÇÃO DE EDUCANDOS DA EJA } \\
\text { DENTRO E FORA DA ESCOLA EMEF “PROF. PEDRO SIMÃO”, EM ALEGRE, } \\
\text { ESPÍRITO SANTO } \\
\text { FOOD NEED FOR EJA STUDENTS RELATED TO FOOD INSIDE AND OUTSIDE } \\
\text { EMEF SCHOOL "PROF. PEDRO SIMÃO", IN ALEGRE, ESPÍRITO SANTO } \\
\text { Manuela Barcelos Martins; Geraldo Moreira Alves; Wanessa Soares Luiz Silva; } \\
\text { Rutheneia Alves Santana; Marcus Antonius Da Costa Nunes; Daniel Rodrigues Silva }\end{array}$ \\
\hline $7-9$ & $\begin{array}{l}\text { O TRABALHO DO ENFERMEIRO JUNTO ÀS MULHERES NA COLETA DO } \\
\text { EXAME CITOPATOLÓGICO NA UNIDADE DE SAÚDE III - SÃO JOSÉ DO } \\
\text { CALÇADO-ES } \\
\text { THE NURSE WORK TOWARD WOMEN IN THE COLLECTION OF THE } \\
\text { CYTOPATHOLOGICAL EXAMINATION IN HEALTH UNIT III - SÃO JOSÉ DO } \\
\text { CALÇADO-ES } \\
\text { Sara Castilholi Tiradentes Ramalho; Rutheneia Alves Santana; Geraldo Moreira } \\
\text { Alves; Julianna Godoi De Souza; Juscelio Abreu Clemente; Roberto Santos Barbieri; } \\
\text { Marcus Antonius Da Costa Nunes; Luana Frigulha Guisso; Wanessa Soares Luiz } \\
\text { Silva; Bruno Augusto De Rezende; Daniel Rodrigues Silva }\end{array}$ \\
\hline
\end{tabular}




\title{
Revista SODEBRAS - Volume 14 $\mathrm{N}^{\circ} 157$ - JANEIRO/ 2019
}

\section{O CLUBE DE TROCAS DA ITCP/UNIFAL-MG E A EXTENSÃO UNIVERSITÁRIA: APROXIMAÇÕES E DESDOBRAMENTOS}

\section{THE EXCHANGE CLUB FROM ITCP/UNIFAL-MG AND THE UNIVERSITY EXTENSION PROGRAM: APPROXIMATIONS AND UNFOLDING}

\author{
KAIO LUCAS DA SILVA ROSA ${ }^{1}$; LUCAS EDUARDO JUVENTINO'; \\ DIMITRI AUGUSTO DA CUNHA TOLEDO ${ }^{1}$; ANA CAROLINA GUERRA ${ }^{1}$ \\ 1 - UNIVERSIDADE FEDERAL DE ALFENAS \\ kkaiorosa98@gmail.com; lukas_lej@hotmail.com; dimitritoledo@hotmail.com; \\ anacarolguerra@yahoo.com.br
}

\begin{abstract}
Resumo - Este trabalho tem como objetivo apresentar o Clube de trocas da Incubadora Tecnológica de Cooperativas Populares da Universidade Federal de Alfenas - ITCP/UNIFAL-MG enquanto projeto de extensão com decorrências no contexto contemporâneo de consumo. Para isso, foi realizada uma análise por meio das confluências entre a literatura $e$ o arsenal documental do projeto para sua caracterização extensionistas. Observou-se, a partir da pesquisa, que o Clube de Trocas tem possibilitado a ressignificação do consumo e a mitigação de suas consequências, pautando assim a construção de uma nova epistemologia benéfica e solidária. Além disso, o mesmo tem se apresentado como um espaço potencial para a formação coletiva que propicia a experimentação e a vivência de outra dinâmica de consumo, direta, critica e socializadora.
\end{abstract}

Palavras-chave: Extensão Universitária. Economia Solidária. Clube de Trocas da ITCP/UNIFAL-MG. Consumo.

\begin{abstract}
Abstract - This paper's objective is to present the Exchange Club from the Popular Cooperative's Technological Incubator from Federal University of Alfenas - ITCP/UNIFAL$M G$ as an extension outreach program with relations to contemporary consumership context. In this regard, an analysis was done by means of the confluences between literature and program documentation for his extensionist characterization. It was observed from research that the Exchange Club allows for ressignification of consumption and mitigation of its consequence, guiding the construction of a new solidary and beneficial epistemology. Also, the exchange club has presented itself as a potential space for collective formation that propitiates the experimentation and the living of another consumership dynamic, one that is direct, critical and socializing.
\end{abstract}

Keywords: Extension Program. Solidary Economy. Exchange Club from ITCP/UNIFAL-MG. Consumption.

\section{INTRODUÇÃO}

$\mathrm{O}$ propósito fundamental deste texto é traçar uma perspectiva a partir da qual seja possível demonstrar o Clube de trocas da ITCP/UNIFAL-MG enquanto projeto de extensão com decorrências no contexto contemporâneo de consumo. Para isso, além da presente sessão prévia, foram estruturadas as sessões: o clube de trocas realizado pela ITCP/UNIFAL-MG; potencialidades da extensão universitária; procedimentos; resultados e por fim, as conclusões.
No contexto marcado pela interiorização das práticas e convicções capitalistas, é facilmente observável a realidade socioeconômica vinculada a práticas como o consumo inconsciente, supervalorização das riquezas materiais, precarização do trabalho, alienação e esgarçamento das relações de consumo.

O processo de formação desse quadro generalizado é observável à medida que a hegemonia do capital e do consumo avançam portando como estandarte a cultura da conformação generalizada. Conforme Harvey (2009), a globalização junto à modernidade viabilizou o consumo desenfreado, fortalecendo o capitalismo e tornando-se assim um ciclo que o fortalece. Isso pode ser percebido através do papel desempenhado pelo consumo em meio à cultura contemporânea, fortemente marcada pela reprodução material.

Ante a cultura contemporânea, fortemente marcada pela reprodução material, “[...] o consumo surge como modo ativo de relação, de atividade sistemática e de resposta global, que serve de base a todo nosso sistema cultural" (BAUDRILLARD, 1995 p. 11). Tomando o consumo como eixo central para a investigação da sociedade, é possível interpretá-la por meio daquilo que a descreve. Neste contexto, tem-se, um elemento que revela os valores presentes no imaginário da sociedade contemporânea e dá sentido às convenções que, por meio de um processo de regularização homogênea, norteiam e organizam a vida social ante rígidos paradigmas em que "[,,,] o consumo é a própria arena em que a cultura é o objeto de lutas que lhe conferem forma" (DOUGLAS; ISHERWOOD, 2004, pp. 102-103).

A conformação da realidade, marcada pela riqueza material e o modo com o qual ele dispõe as relações sociais de consumo e de trabalho assalariado, representa em um plano amplo e coletivo, a necessidade de movimentos que repensem a lógica de consumo enquanto práticas da Economia Solidária que surgem como:

\footnotetext{
"modo de produção e distribuição alternativo ao capitalismo, criado e recriado periodicamente pelos que se encontram (ou temem ficar) marginalizados do mercado de trabalho. A Economia Solidária casa o princípio da unidade entre posse e uso dos meios de produção e distribuição (da produção simples de
} 
mercadorias) com o princípio da socialização destes meios (do capitalismo) (SINGER, 2003, p.13)."

Enquanto modos recorrentes de reprodução da Economia Solidária, os Clubes de Trocas surgem de iniciativas em meio a conjunturas de recessão econômica que alcançaram os mais diversos territórios e impactaram inúmeras conformações de mercado.

"O primeiro clube de troca no Brasil foi inaugurado
em 1998, em São Paulo, bairro de Santa Terezinha,
Santo Amaro. No começo, inspirou-se na iniciativa
francesa denominada "trocas de saber" e depois,
passou a incorporar bens e serviços, atuando de
forma parecida com o modelo argentino. Em 1999,
teve início a experiência no Rio de Janeiro, seguida
de Porto Alegre e várias outras cidades brasileiras
(SINGER. 2000, p. 290)."

Após esses seus primeiros desdobramentos, os Clubes de Trocas difundem-se como práticas por parte de diversas Incubadoras Tecnológicas de Cooperativas Populares ITCP's. Nessa perspectiva é que surge o Clube de Trocas da ITCP/UNIFAL-MG como importante proposta de ação extensionistas, caracterizando-se como um Projeto de extensão realizado desde 2011 cuja importância é verificada por meio da intervenção social realizada ante o contexto marcado pelo consumo inconsciente.

\section{O CLUBE DE TROCAS REALIZADO PELA ITCP/UNIFAL-MG}

Com edições realizadas no campus da universidade, no Centro Federal de Educação Tecnológica de Minas Gerais -

CEFET-MG e no centro da cidade de Varginha-MG. o Clube de Trocas atinge com grande efetividade o público pretendido: conta com a participação significativa da comunidade acadêmica, vai ao encontro da comunidade externa e também democratiza o acesso às dependências da universidade.

Em relação ao seu desenvolvimento, ocorre a preparação prévia ao clube, através de um processo de formação científica e interpessoal dos membros da ITCP/UNIFAL-MG. Inicialmente, os participantes são convidados a se apresentarem assim como aquilo que foi levado para troca - tanto objetos, serviços, saberes e afetividade.

Viabilizada a socialização e integração, são transmitidos dialogicamente os princípios metodológicos e científicos fundamentais, tanto a respeito da Economia solidária e seus princípios, como também, a respeito da origem dos Clubes de Trocas, sua importância e suas implicações nas relações sociais e de consumo.

Posteriormente, as trocas são realizadas entre os participantes de modo autogestionário, cooperado e solidário, permitindo a socialização e $\mathrm{o}$ crescimento coletivo, possibilitando a realização das relações de consumo conforme outra epistemologia, segundo valores não praticados na sociedade capitalista.

Discorde à constante mercantilização cultural, os clubes contam com atrações como apresentações musicais, oficinas de dança, apresentações de grupos de dança, declamações, murais literários e ainda, murais para expressão pessoal. Tudo isso sinaliza o modo com que, em meio ao ambiente agradável e descontraído, os clubes criam alternativas para democratização da cultura construída a partir de vieses populares.

As edições são sempre encerradas com uma reflexão coletiva a respeito de tudo que foi realizado, assim procurase que os participantes compartilhem conhecimentos, experiências e demais aprendizados adquiridos a respeito da formação vivenciada. É incentivado também que todos esses aprendizados continuem sendo praticados e sejam levados adiante, ansiando modificar a realidade vigente.

Atualmente, os Clubes de Trocas são importantes formas de atuação extensionista que se ligam essencialmente aos fins dessa. Por ser conforme a extensão universitária, é preciso retratá-la para ser possível indagar, compreender e significar o que tem proposto o referido Clube de Trocas. Para que seja possível fazê-lo, portanto, é mister conceber a extensão universitária a qual se reporta.

\section{POTENCIALIDADES DA EXTENSÃO UNIVERSITÁRIA}

No Brasil, como forma de resistência a submissão a métodos extensionistas externos, como também, impulsionado pelo processo de redemocratização e valorização das pautas sociais, as concepções do pensamento de Paulo Freire passam a realizar grande influência sobre o modelo extensionista no Brasil, contribuindo fortemente para o nascimento de um novo movimento de reorganização da extensão universitária:

De acordo com Serrano (2013) as ideias e práticas de Paulo Freire passaram a fundamentar os conceitos e práticas da Extensão Universitária que se institucionalizaram a partir dos anos 80. É inaugurada a discussão sobre indissociabilidade da atuação acadêmica e o conceito da extensão como via de mão dupla, como produção de conhecimento e forma de troca comum.

E, essa ligação entre universidade e sociedade configura importantes fundamentos para a extensão universitária, que, segundo o Fórum de Pró-Reitores de Extensão das Universidades Públicas Brasileiras FORPROEX, define-se como:

\begin{abstract}
"O processo educativo, cultural e científico que articula o Ensino e a Pesquisa de forma indissociável e viabiliza a relação transformadora entre Universidade e Sociedade. A Extensão é uma via de mão-dupla, com trânsito assegurado à comunidade acadêmica, que encontrará, na sociedade, a oportunidade de elaboração da práxis de um conhecimento acadêmico. No retorno à Universidade, docentes e discentes trarão um aprendizado que, submetido à reflexão teórica, será acrescido àquele conhecimento. Esse fluxo, que estabelece a troca de saberes sistematizados, acadêmico e popular, terá como consequências a produção do conhecimento resultante do confronto com a realidade brasileira e regional, [...] (FÓRUM NACIONAL, 1987).”
\end{abstract}

De acordo com Nunes e Silva (2011), para fortalecer a relação entre universidade e sociedade, se faz necessário, priorizar a superação das condições de desigualdades e exclusão existentes. Onde a universidade socializa seus conhecimentos e disponibiliza seus serviços, exercendo sua responsabilidade social. Ainda de acordo com o FORPROEX, são alguns dos objetivos da Extensão Universitária: 
"Reafirmar a extensão universitária como processo acadêmico definido e efetivado em função das exigências da realidade, indispensável na formação do aluno, na qualificação do professor e no intercâmbio com a sociedade;

assegurar a relação bidirecional entre a universidade e a sociedade, de tal modo que os problemas sociais urgentes recebam atenção produtiva por parte da universidade;

considerar as atividades voltadas para o desenvolvimento, produção e preservação cultural e artística como relevantes para a afirmação do caráter nacional e de suas manifestações regionais (FÓRUM NACIONAL, 1998)."

Devido à insustentabilidade das relações de consumo contemporâneas - marcadas pela desigualdade, superexploração de recursos naturais, distribuição desigual de conhecimentos e acumulação de capital - portanto, é que surgem movimentos alternativos como a Economia Solidária e suas consequentes manifestações significativas para o âmbito extensionista. Entre essas práticas, destacamse os Clubes de Trocas como possibilidade para se repensar as relações de consumo de modo experimentado e coletivo.

Nesse contexto, este estudo tem como objetivo analisar comparativamente os aspectos teóricos da extensão universitária e as práticas do Clube de Trocas da ITCP/UNIFAL-MG. Pretende-se ainda caracterizar o modo como o Clube de Trocas enquanto atividade extensionista entre Universidade e Sociedade visa contribuir para a constituição de mobilizações transformadoras e, portanto, fundamentais.

\section{PROCEDIMENTOS}

A metodologia empregada para esta pesquisa possui conformação qualitativa, a qual, segundo Silveira e Córdova (2009), preocupa-se com os aspectos da realidade, que por serem complexos e pragmáticos não possuem quantificação, centrando assim, na dinâmica que apresenta as relações sociais.

Houve, preliminarmente, a pesquisa e síntese em relação à extensão universitária por meio da pesquisa bibliográfica, que "é fundamentada nos conhecimentos de biblioteconomia, documentação e a bibliografia; sua finalidade é colocar o pesquisador em contato com o que já foi produzido e registrou a respeito do seu tema de pesquisa" (PÁDUA, 2007, p. 55).

Logo após, traçou-se o modo de atuação do Clube de Trocas da ITCP/UNIFAL-MG e seus desdobramentos mediante a pesquisa documental que, para Flick (2009), emprega métodos e técnicas para a apreensão, compreensão e análise de documentos dos mais variados tipos. Para isso foi examinado o referencial pertencente à ITCP/UNIFAL$\mathrm{MG}$, composto por resumos, relatórios, artigos, pesquisas e demais produções.

Por meio de categorias confluentes, como o que constitui, o que ambiciona, o que realiza e as implicações que possuem a ação extensionista e o clube de trocas da ITCP/UNIFAL-MG, o referido clube foi considerado neste trabalho sob a composição da extensão universitária, suscitando decorrências que possibilitaram atingi-lo enquanto projeto com desdobramentos recorrentes daquilo que o significa: a própria atuação dentro do continuum extensionista.

\section{RESULTADOS}

Enquanto um dos projetos do programa ITCP/UNIFAL-MG, o Clube de trocas encontra-se inserido dentre os fins da extensão universitária que pretendem um processo educativo, cultural, científico indissociável e indispensável na formação do aluno, na qualificação do professor e no intercâmbio com a sociedade. ${ }^{1}$

Esse processo apresenta-se presente desde a preparação e formação interna dos componentes da ITCP/UNIFAL-MG para realização do seu Clube de Trocas, como também, pela criação de um espaço interativo e dinâmico na universidade. Possibilitando que discentes, docentes e toda comunidade universitária interajam com a sociedade externa, realizando a nível material e formativo um processo educacional.

Participaram dos clubes de troca, a comunidade acadêmica da UNIFAL - MG, os membros dos grupos incubados, além de moradores da cidade. Em todos os encontros de troca há momentos prévios de discussão dos preceitos da Economia Solidária, numa tentativa de se dialogar acerca do modelo econômico e social existente, e o proposto pela Economia Solidária. Além disso, ocorre uma discussão sobre o consumo em si, e como ele contribui para a forma desigual que se dá o desenvolvimento nacional. ${ }^{2}$

Assim, apesar de também teórica, a formação suscitada por meio do Clube de Trocas da ITCP/UNIFAL-MG extrapola esse aspecto formal. Os docentes e discentes entram em contato direto com uma estrutura de trocas de conhecimentos informais. Portanto, todos envolvidos são inseridos em uma esfera de crescimento conjunto, onde são compartilhados saberes sobre o consumo, suas relações, implicações e, especialmente, a respeito de possibilidades para superação dessa realidade através de um modo de proceder crítico

O funcionamento do Clube de Trocas provém da confiança que existe entre as pessoas que estão participando, não é um lugar para se obter lucros e sim para se ajudar mutuamente. A atitude de cada um é que acaba por formar o todo, pois para desenvolver uma sociedade sustentável requer um consumo consciente de cada um dos indivíduos. Nesse sentido, a compreensão de outros valores, não só aqueles propostos pelo mercado capitalista, contribuem de forma significativa para a formação cidadã dos alunos. ${ }^{3}$

$O$ Clube de Trocas possui uma metodologia não “estanque", flexível, de natureza participativa, baseado no reconhecimento dos valores culturais, do saber e das demandas do público; emancipador no sentido pedagógico do termo, explorando a aplicação educativa das técnicas de dinâmica de grupo para que o público desenvolva consciência crítica a atinjam a autogestão; rejeita a reprodução de propostas de intervenção pré-concebidas que nega os valores culturais e as formas do conhecimento coletivo e individual e valoriza o diálogo, a capacidade reflexiva, a construção coletiva de novas normas de convivência social. ${ }^{4}$

Cumprindo assim com a perspectiva de extensão que por meio de seu procedimento não acomodado atue

\footnotetext{
${ }^{1}$ Fórum de Pró-Reitores de Extensão das Universidades Públicas Brasileiras (1998).

${ }^{2}$ Relatório das atividades do Clube de Trocas da ITCP/UNIFALMG (2015).

${ }^{3}$ Ibid., (2011).

${ }^{4}$ Ibid., (2013).
} 
"viabilizando a organização política do grupo, em que além da promoção de uma consciência crítica se almeja a intervenção na realidade em uma perspectiva transformadora e libertadora, da autonomia do sujeito" (JEZINE, 2004, p. 3).

Outra proposta da extensão universitária é contemplar atividades voltadas para o desenvolvimento e produção cultural, socializando-as com toda a comunidade por meio de um processo: educativo, cultural e científico. ${ }^{5}$ Concorde a esse objetivo, Há ainda, diferentes performances e atividades artísticas e culturais que são realizadas nos clubes: apresentações de grupos de dança de rua, como o DBlack Crew no ano de, oficinas de forró, declamações literárias, as mais diversificadas apresentações musicais, como o Maracatu, declamações e performances poéticas ocorridas no mesmo ano, murais livres para o exercício artístico pessoal, varais literários, palco aberto e demais possibilidades que compõe um ambiente construtivo, agradável e descontraído. ${ }^{6}$

Os clubes têm cumprido, desse modo, a extensão universitária enquanto possibilidades representadas pela finalidade de "afirmar-se como um lócus de identidade em que, tanto o conhecimento produzido na universidade como o conhecimento produzido pela comunidade, sejam considerados bases da produção cultural e social dos sujeitos em seus grupos" (DA COSTA, SANTOS, GRINSPUN, 2009, p. 359).

Em relação a sua fundamental função, é importante ressaltar como o Clube de Trocas enquanto ação de extensão permite o lançamento de bases que são meios de se reconsiderar as prática e relações de consumo e totalidades na vivência da economia solidária, tudo isso sinaliza os impactos decorrentes dos clubes para a construção de uma nova realidade, mitigando o antagonismo de classes, reavendo o sistema de consumo, exploração e concentração de riquezas.

O Clube de Trocas tem como propósito o incentivo a novas práticas de consumo entre os participantes, práticas mais solidárias, de trabalho e organização do trabalho coletivo, e sem exploração, seja do indivíduo, do capital ou mesmo dos recursos naturais. ${ }^{7}$

Conforme constatado através dos resultados anteriormente apresentados, o Clube de Trocas da ITCP/UNIFAL-MG efetiva a extensão universitária. Logo, essa afirmativa ilustra o resultado positivo obtido em relação à comparação anteriormente pretendida e agora realizada. A partir dessa implicação intuímos a importância do Clube de Trocas por meio daquilo que é por ele realizado enquanto projeto de extensão.

\section{CONCLUSÃO}

Uma vez realizada a abordagem comparativa acerca dos conceitos teóricos da extensão universitária em relação às produções sobre o Clube de Trocas da ITCP/UNIFALMG, os resultados obtidos justapõem-se com grande efeito, evidenciando o modo com que se associam e dão-se significado.

\footnotetext{
${ }^{5}$ Fórum de Pró-Reitores de Extensão das Universidades Públicas Brasileiras (1987).

${ }^{6}$ Relatório de atividades da ITCP/UNIFAL-MG (2018).

7 Relatório das atividades do Clube de Trocas da ITCP/UNIFALMG (2015).
}

Nesse sentido, o Clube de Trocas da ITCP/UNIFALMG é percebido enquanto importante projeto de extensão uma vez que produz conhecimentos de modo indissociável. $\mathrm{O}$ processo formativo interno e o contato direto com a comunidade, realizados durante as trocas são igualmente fundamentais para a construção do processo educativo transformador, pautado principalmente pela relação dialógica.

A realização dos clubes valoriza a comunidade externa enquanto propagadora de uma nova realidade e fomenta práticas artísticas para socialização cultural. Práticas essas que estimam a cultura regional e os saberes locais, valorizando em todos os aspectos a comunidade alcançada.

Em suas edições o Clube de Trocas da ITCP/UNIFALMG coletiviza o espaço da universidade, voltando-a para seu fim fundamental: ser um espaço público. Além disso, quando realizado externamente, esse Clube alcança toda a comunidade para seus fins, socializando conhecimento e disponibilizando serviços para efetivação das responsabilidades sociais pretendidas. Enquanto produtos das edições do projeto, suas implicações e vivências culminam na realização de produções que associam pesquisa e extensão dentro das ações transformadoras da realidade.

Por meio do Clube de Trocas da ITCP/UNIFAL-MG, espaços de grande abrangência tornam-se vetores propícios para reconsideração do contexto capitalista. Os Clubes assim são imprescindíveis para a ressignificação dos valores das mercadorias, das relações de consumo, das relações interpessoais e para socialização da cultura e de conhecimentos. Tudo isso possui aspectos fundamentais presentes na atribuição universitária que abriga o projeto em questão como um vetor significativo de tudo aquilo que ela pretende.

\section{REFERÊNCIAS}

BAUDRILLARD, J. A sociedade de consumo. Lisboa, Edições 70, 1995.

DA COSTA, P. M.; SANTOS, S. R. M. S.; GRINSPUN, M. P. S. Z. Extensão Universitária e o Campo da Política Cultural. Revista Meta: Avaliação, v. 1, n. 3, p. 352-368, 2009.

DOUGLAS, M.; ISHERWOOD, B. O mundo dos bens. Rio de Janeiro: UFRJ, 2004.

FLICK, U. Introdução à pesquisa qualitativa. Trad. Joice Elias Costa. 3. ed., Porto Alegre: Artmed, 2009.

BRASIL/MEC. I Fórum Nacional de Pró-Reitores de Extensão das Universidades Públicas Brasileiras. Brasília, 1987.

BRASIL/MEC. XI Fórum de Nacional de Pró-Reitores de Extensão das Universidades Públicas Brasileiras. Natal, 1998.

HARVEY, D. O. Neoliberalismo: histórias e implicações. São Paulo: Loyola, 2009.

JEZINE, E. As práticas curriculares e a extensão universitária. In: CONGRESSO BRASILEIRO DE EXTENSÃO UNIVERSITÁRIA, 2., 2004, Belo Horizonte. Anais... Belo Horizonte, 2004. Disponível em: <http://br.monografias.com/trabalhos-pdf901/as-practicas- 
curriculares/as-practicas-curriculares.pdf $>$. Acesso em: 10 set. 2018.

NUNES, A. L. P. F.; SILVA, M. B. C. A extensão universitária no ensino superior e a sociedade. Mal-Estar e Sociedade, v. 4, n. 7, p. 119-133, 2011.

PÁDUA, Elisabete Matallo Marchesini de. Metodologia da pesquisa: abordagem teórico prática. 13. ed. Campinas: Papirus Editora, 2007.

SERRANO, R. M. S. Conceitos de extensão universitária: um diálogo com Paulo Freire. Grupo de Pesquisa em Extensão Popular, v. 13, n. 8, 2013.

SILVEIRA, D. T; CÓRDOVA, F. P. A. A Pesquisa Cientifica. In: GERHARDT, T. E; SILVEIRA, D. T. (Orgs). Métodos de Pesquisa. Porto Alegre: Editora da UFRGS, 2009.

SINGER, P. Economia Solidária: um modo de produção e distribuição. In: SINGER, P. SOUZA, A.R. A Economia Solidária no Brasil: A autogestão como resposta ao desemprego. São Paulo: Contexto, 2003. p. 11-30.

SINGER, P. A economia solidária no Brasil. A autogestão como resposta ao desemprego. São Paulo, Contexto, 2000.

\section{COPYRIGHT}

Direitos autorais: Os autores são os únicos responsáveis pelo material incluído no artigo. 


\title{
O PACTO NACIONAL PARA A ALFABETIZAÇÃO NA IDADE CERTA COMO AÇÃO INOVADORA PARA O LETRAMENTO DE CRIANÇAS NO BRASIL
}

\author{
THE NATIONAL COVENANT FOR LITERACY IN THE RIGHT AGE AS \\ INNOVATIVE ACTION FOR THE LETTERING OF CHILDREN IN BRAZIL
}

\author{
MÁRCIA LOPES REIS'; AMANDA BARBOSA GASPAR DE LIMA² \\ 1; 2 - UNIVERSIDADE ESTADUAL PAULISTA “JÚLIO DE MESQUITA FILHO” (UNESP - BAURU) \\ malo.reis@uol.com.br; amanda.bglima@gmail.com
}

\begin{abstract}
Resumo - Este artigo aborda o tema dos processos de inovação na gestão da alfabetização na idade certa que representa uma ação governamental na perspectiva da formação continuada. $O$ objetivo específico foi identificar nas concepções e percepções dos coordenadores que atuam na alfabetização dos anos iniciais do ensino se houve inovação das práticas no cotidiano escolar com a introdução do PNAIC. A pesquisa etnográfica realizada permite inferir que houveram atrasos e descontinuidade na implementação desta política.
\end{abstract}

Palavras-chave: Pacto Nacional para Alfabetização na Idade Certa. Gestão Educacional. Letramento.

\begin{abstract}
This article approaches the theme of innovation processes in the management of literacy at the right age that represents a governmental action from the perspective of continuing education. The specific objective was to identify in the conceptions and perceptions of the coordinators who act in the literacy of the initial years of the teaching if there was innovation of the practices in the school routine with the introduction of the PNAIC. The ethnographic research carried out allows us to infer that there were delays and discontinuities in the implementation of this policy.
\end{abstract}

Keywords: National Pact for Literacy in the Right Age. Educational Management. Literacy.

\section{INTRODUÇÃO}

O mundo atual vem tomando a forma da globalização e do excesso desenvolvimento tecnológico. A Era da informação contrasta com a defasagem do desenvolvimento social (CASTELLS, 1999). Toda política pública educacional deveria trabalhar para o crescimento social, não meramente enfatizar os avanços tecnológicos como primordiais, mas apenas utilizá-los ou aprimorá-los quando um eleva a qualidade existencial do outro. Partindo deste princípio, escolhemos o Pacto Nacional pela Alfabetização da Idade Certa (PNAIC), uma política diretamente ligada à qualidade da formação continuada dos professores e coordenadores alfabetizadores e do esforço coletivo em promover a alfabetização de todas as crianças até os oito anos idade.

Ao se referir às ações de caráter estatal ou governamental, para a educação, Tardif (2011), analisa que os sistemas de ensino ocidentais se encontram, atualmente, diante de exigências e desafios, sem precedentes, suscitados pela universalização da escola em todos os níveis do sistema de ensino, onde os professores e formadores assumem uma posição estratégica em meio às relações complexas que unem as sociedades aos saberes que elas produzem e mobilizam.

Por isso, analisar as percepções de gestores e professores é importante a medida que auxiliará no debate acerca das ações facilitadoras para a melhoria do processo de alfabetização e da redução da distorção idade série. E ainda poderá contribuir para um mapeamento e avaliação dessa importante política pública que é o Pacto Nacional para Alfabetização na Idade Certa.

Dessa forma, tentaremos resgatar brevemente quando esta política foi criada e quem seriam os responsáveis por sua implementação. Esta política de cunho nacional, instituída com a portaria $\mathrm{N}^{\circ} 867$, de 4 de julho de 2012, teve início em 2013 e foi ofertada aos professores alfabetizadores e coordenadores pedagógicos das redes públicas, em serviço, por Instituições de Ensino Superior (IES), regularmente instituídas pelas redes públicas. No caso do estado de São Paulo, em 2016, ficou estabelecido que o Comitê Gestor Estadual seria realizado pela Universidade Estadual Paulista "Júlio de Mesquita Filho (UNESP) e a Universidade Federal de São Carlos (UFSCar), ambas localizadas no interior de São Paulo.

O Pacto foi fundamentado no programa PróLetramento, cuja metodologia de formação previa a melhoria da qualidade da aprendizagem da leitura/escrita e matemática nos anos iniciais do ensino fundamental. $\mathrm{O}$ desenvolvimento do Pacto desde a implementação até o ano de 2016, não ocorreu de maneira linear, pois apresentou tentativas de ampliações, mas também descontinuidades. Em 2013, a formação teve início com o ensino da Língua Portuguesa e, mais tarde, teve o acréscimo da formação em Matemática. Em 2014, os cadernos já traziam a importância da interdisciplinaridade. Em 2016, foi acrescentado na formação o princípio da gestão democrática. As universidades responsáveis por implementar a formação em prática buscaram orientação na garantia dos direitos de aprendizagem das crianças que devem constituir o ciclo de alfabetização. No entanto, houve um processo de descaracterização dessa proposta que, ao longo de sua implementação, parece haver perdido o compromisso com os direitos de aprendizagem, passando a ser orientanda para as avaliações externas Pacto com a Avaliação Nacional da Alfabetização (ANA), em 2016. Além disso, uma 
intercorrência na gestão nacional do PNAIC deixou indícios de que a formação seria descontinuada, colocando fim no trabalho em andamento. Expresso no próprio nome, pressupõe o envolvimento de distintos sujeitos com responsabilidades a serem compartilhadas por um período para atingir metas e objetivos.

A proposta da interdisciplinaridade estava nos cadernos de formação, mas o foco das formações permaneceu no ensino da Língua Portuguesa e Matemática focando na preparação para a avaliação externa, a ANA. Segundo Cunha (2003), as avaliações externas pressupõem a existência de uma presença paradigmática dominante que, não raras vezes, impõe a homogeneização como paradigma, sendo um fator de retração da inovação, pois estas teriam como princípios a implementação de um modelo único de qualidade, sem ao menos discutir suas condições e contextos.

O PNAIC contou, também, com a inclusão do princípio da gestão democrática na formação respondendo ao PNE (Plano Nacional de Educação) que levanta a necessidade de superação da visão fragmentada de gestão presente no sistema de ensino, de forma que, gestores, profissionais da escola, estudantes, pais, a sociedade e entes federativos, estejam comprometidos com a elaboração dos planos de educação. Com formas de participação distintas, devem estar articulados conforme previsto pela Constituição Federal (1988) no alcance dos direitos de aprendizagem.

O PNE enfatiza, ainda, que o fomento à qualidade da educação básica constitui-se um desafio complexo que se vincula a uma trajetória histórico-social e a um projeto de nação:

“[...] fomentar a qualidade da educação básica implica enfrentar a desigualdade social existente no País e assegurar a educação como um dos direitos humanos. Implica também melhor definição e articulação entre os sistemas de ensino e unidades escolares, processos de organização e gestão do trabalho escolar, melhoria das condições de trabalho e valorização, formação e desenvolvimento profissional de todos aqueles que atuam na educação (BRASIL, 2014, p. 32).”

A inclusão do princípio de gestão democrática, por lei, pode ter representado uma grande conquista em termos de direito para a nação, Constituição Federal inciso VI do art. 206, LDBEN inciso $\mathrm{n}^{\circ}$ VIII do art. $3^{\circ}$ e meta do Plano Nacional de Educação (Lei 13005 de 25 de junho de 2014). Mas o desafio em proporcionar a sua efetivação se tornou precípua, sobretudo, pela dificuldade dos professores em assumirem com outros sujeitos, o protagonismo das relações pedagógicas e administrativas que perpassam o espaço organizacional da escola.

Nesse sentido, procuramos contextualizar a implementação dessa ação como parte decorrente de uma política, cujos princípios representam parte do processo de (re) democratização no Brasil, ocorrido no final dos anos 1970, que resultaram sistematização das garantias de direitos cidadãos constitucionais entre os quais a preocupação com a educação para todos e com qualidade se fizeram presentes. A promulgação da Constituição Federal de 1988, Estatuto da Criança e do Adolescente (1990) e a Lei de Diretrizes e Bases da Educação Nacional da Educação Nacional (LDBEN) de 1996 foram os marcos legais que trouxeram o reconhecimento da criança, protagonista dos processos de letramento, como sujeito de direitos com direito à assistência, à saúde e à educação. A educação básica tornou-se obrigatória e gratuita a ser garantida dos quatro aos dezessete anos de idade, organizados em: educação infantil, ensino fundamental e ensino médio. Essas mudanças inauguraram no Brasil o dever do Estado em garantir os direitos inalienáveis à educação, ampliando o acesso, a permanência estudantil.

No entanto, garantia ao acesso e à permanência estudantil, enfrentam o problema da legitimação de ocupação desses espaços que são seus por direito. Não é novidade pra ninguém o discurso do fracasso escolar, de que estamos distantes da qualidade de ensino, com avaliações externas, com dados que apontam para o fracasso escolar, desde os momentos de alfabetização e evidenciados pelas distorções idade-série, desde os primeiros anos.

De acordo com Patto (1999), a natureza do discurso educacional sobre a reprovação escolar surgiu no século XIX, com a expressão cultural da nova ordem social que emerge do feudalismo, bem como das primeiras teorias racistas subsidiadas pelo cientificismo. De acordo com a autora, as explicações do fracasso escolar têm uma história pautada pela divisão social, não mais em servo-senhor feudal, mas em classes superiores e inferiores, tendo como critério o talento individual. A autora ressalta, ainda, que a Revolução de 1789 (Francesa) manifestou a primeira expressão oficial do nacionalismo com o advento dos sistemas nacionais de ensino, pois a burguesia defendia um regime constitucional por onde ela pudesse defender os interesses do povo, entendido como nação. Assim, teria surgido a ideia de escola universal, obrigatória e redentora da humanidade assumida como meio de obter a unidade nacional. No entanto, durante o século XX, com a Primeira Guerra Mundial, o ideal da escola redentora da humanidade foi desmentido, pois a posse do alfabeto, da constituição e da imprensa, da ciência e da moralidade não havia sido capaz de livrar os homens da tirania, da desigualdade social e da exploração. Daí, surgem as críticas à pedagogia tradicional e, assim, uma política educacional que deveria propagar a paz e a democracia. Contudo, este novo ideal baseava-se, ainda, na crença de que a escola poderia levar a construção de uma sociedade igualitária pelo mérito pessoal.

Passados esses anos iniciais, entramos no século XXI e percebemos que a gestão de políticas públicas educacionais deve enfrentar inúmeros problemas nos quais a problematização do que seria o fracasso escolar, e se ele de fato existe, que é que sofre de fato, para que seja analisada com a devida atenção e cuidado. Sobretudo, quando se notam que os processos de gestão precisam lidar tanto com o paradigma fabril de onde nasceu, tendo em sua base as teorias da administração de empresas que já não se apresentam suficientes para gerir uma escola dos novos tempos e que demanda tratamento humanizador.

No cenário atual, essa necessidade pode ser notada pela ocorrência das ocupações de escolas públicas em todo o país que, ao longo de 2016, deixou evidente a necessidade de fortalecer as relações interpessoais que levam à gestão democrática, de maior participação, bem como uma política horizontal como modelo para a escola. Esta situação vivenciada e promovida pelos estudantes colocou em questão a política vertical, bem como o método de ensino tradicional, que tem como herança as carteiras enfileiradas que não favorecem as interações sociais, como afirmou uma aluna do movimento em uma tribuna. O cenário atual parece demonstrar que a questão da gestão e da inovação de saberes 
escolares, desde a alfabetização, são necessários para que a escola usufrua do mundo tecnológico sem deixar para o aspecto fundamental humano.

Diante deste cenário, a figura do gestor que, de acordo com Amorim (2015), desempenha um papel significativo na construção de um projeto mais dinâmico para escola pública, um projeto que contemple a prática pedagógica e administrativa, comprometido com a qualidade e o sucesso educacional de todos os estudantes que passam pelas instituições de ensino. No entanto, diante da atual situação escolar, o autor ressalta que os gestores quando chegam ao ambiente educacional, encontram inúmeras dificuldades para desenvolverem suas atividades profissionais, situações que acabam contribuindo para o não fortalecimento da prática pedagógica e de valores humanos tão necessários à construção da cidadania. Nesse sentido, Paro (2010) exemplifica bem o fato de que é senso comum culpar, em grande parte, a má administração das nossas escolas, especialmente aquelas mantidas pelo poder público, quando o ensino não está bom.

Porém, existem outros fatores que contribuem para desencontros, como o próprio contexto em que a escola surge e desenvolve. No Brasil, a democratização de uma escola, tradicionalmente elitista, veio acompanhada pelo descompasso observável desde a alfabetização escolar e, consequentemente, tornou-se recorrente culpar o próprio aluno pelo fracasso, enfatizando preconceitos sociais.

Como exemplo, podemos citar a transição do ensino de Português na escola. Segundo Bezerra (2007), a tradição da escola no ensino de Língua Portuguesa, no Brasil, foi voltada para a exploração da gramática normativa que tinha como objetivo levar ao conhecimento às classes mais abastadas as regras gramaticais e de funcionamento dessa variedade linguística de prestígio. Além disso, quando a classe abastada terminava sua alfabetização iniciava seus estudos na gramática do latim ao lado da retórica e da poética. Porém, o autor destaca que quando a disciplina de Português passou a integrar os currículos escolares seguiuse o modelo conhecido e que atingia aos objetivos propostos. Dessa forma, a eleição de uma língua como correta, nada teria a ver com a sua qualidade intrínseca, mas seria determinada por fatores históricos, econômicos e sociais, que relegam as outras de formas de falar como errôneas, deselegantes, inadequadas, etc (BEZERRA, 2007).

De acordo com Geraldi (1985, p. 43) "a democratização da escola, ainda que falsa, trouxe em seu bojo outra clientela e com ela diferenças dialetais bastantes acentuadas". Obviamente, a nova clientela que passou a frequentar a escola, não falaria de acordo com a forma eleita, padrão, e enfrentaria uma transição permeada pelo preconceito linguístico, e pela culpa por não superar as barreiras impostas. Bagno (1999) em seu livro "Preconceito linguístico- o que é, como se faz, propõe uma reflexão sobre os mitos que sustentariam o embate histórico entre a língua falada e a escrita, que se torna um instrumento de manipulação da verdade e ocultação do outro. O autor cita alguns como: não reconhecer a variedade linguística existente; o mito de que o brasileiro não sabe falar bem o português, ao contrário do que acontece em Portugal; o mito de que o português é muito difícil, pois o que há é a existência de uma gramática normativa de origem portuguesa, que faria necessário uma mudança para uma gramática que fosse brasileira empregada na língua falada. Pois, como está posto, o ensino da gramática privilegia poucos. O autor cita ainda, o mito de que as pessoas sem instrução falam errado; o mito de que se fala assim por se escreve assim; é preciso saber gramática para falar e escrever bem; entre outros mitos que aliados a razões políticas, econômicas, sociais e culturais mantém o domínio da norma culta reservada a poucas pessoas no Brasil. Naturalizados, os mitos ajudam a incutir nas pessoas a ideia que escrevem e falam errado, perpetuando a própria estigmatização.

É importante que se reflita sobre estas contradições para que possamos combater estes preconceitos, por um ensino de língua, que enxerga o ser humano. A proximidade da Universidade com as escolas poderia possibilitar a superação deste grande abismo.

Por outro lado, Geraldi (1985), afirma que reconhecer e, até mesmo partilhar com os alunos tal fracasso, não significa a responsabilização do professor pelos resultados insatisfatórios, pois é conhecido as condições de trabalho enfrentadas pelos professores e a inércia administrativa com que, muitas vezes, a educação tem sido relegada com professores mal pagos e verbas escassas. Os professores não agem isolados de um processo administrativo e de fatos históricos que apresentam inúmeros problemas com a reconhecimento da diversidade e de valorização da existência humana.

Neste sentido, mais do que investimentos maciços em educação, como um clichê, é necessário investimentos na formação humana, na credibilidade no professor e nas crianças que frequentam as escolas, sejam elas de onde forem são capazes de aprender a conhecer a sua realidade sem serem alienadas.

A formação inicial de professores deve ser valorizada, e ela pode através de seus projetos alimentar o diálogo entre universidade e a escola. A formação continuada não deve pôr em xeque a capacidade do professor, mas manter o caminho aberto entre a Universidade e os profissionais que atuam na alfabetização e letramento. A gestão educacional, como uma das dimensões da prática institucionalizada escolar que caracterizam alguns dos profissionais da educação, assume relevância a ser considerada neste artigo. A LDBEN estabelece no art. 61 que a formação dos profissionais da educação em nível superior, bem como a formação continuada e a capacitação para esses profissionais no local de trabalho ou em instituições de educação básica e superior, devem ser promovidas em regime de colaboração entre a União, o Distrito Federal, os Estados e os Municípios.

Estes princípios são reforçados pelo Plano Nacional de Educação (PNE) e têm em vista que a valorização do quadro de profissionais da educação, fundamental para que seja possível o alcance de outras metas estabelecidas para a qualidade da educação brasileira. O PNE reforça, ainda, que profissionais da educação motivados e comprometidos com os estudantes são indispensáveis para o sucesso de uma política educacional que busque a qualidade referenciada na Constituição Brasileira (BRASIL, 2014).

Nesse contexto, consideramos relevante pesquisar o Pacto Nacional para Alfabetização na Idade Certa (PNAIC) como prática inovadora de gestão de políticas públicas de educação básica, tendo em vista que essa seria uma ação de formação dos professores alfabetizadores e coordenadores, em serviço. O PNAIC se apresenta como uma política de formação que integra as Universidades públicas e os professores de ensino fundamental, fator importante para o 
fortalecimento das práticas pedagógicas e de gestão escolares, que poderia também refletir nas mudanças necessárias para que as nossas escolas atendam de fato a diversidade. Sobre as mudanças colocadas em curso no setor educativo, Nóvoa (1999) ressalta a importância de novos mecanismos de formação de professores que passem pela autonomia das Universidades e das escolas que possam traduzir a diversidade de interesses e de realidades.

Ainda no sentido da importância da realidade e do contexto, Thurller (2001) considera que o estabelecimento escolar é determinante nos projetos de mudanças, pois é ali que os professores constroem o sentido de suas práticas profissionais, existindo, assim, uma relação entre as mudanças propostas e o sentido com que elas são assumidas e colocadas em prática nas escolas.

Assim, a pergunta-problema da presente pesquisa pode ser assim sistematizada: Houve práticas inovadoras implementadas pelos professores alfabetizadores e coordenadores pedagógicos nos processos de gestão como resultado da formação do PNAIC?

O objetivo foi identificar, através das concepções e percepções dos coordenadores que atuam na alfabetização dos anos iniciais do ensino fundamental, se observavam inovações, se sim, o que eles consideraram como inovações que resultaram na melhoria da qualidade do ensino dos professores entrevistados.

\section{PROCEDIMENTOS}

O método utilizado, nesta pesquisa, foi delineado a partir do objetivo que tratou de investigar através das concepções e percepções dos coordenadores que atuam na alfabetização dos anos iniciais do ensino fundamental de uma escola pública se houve, de fato, um caráter de inovação nas suas práticas e, se resultaram na melhoria da qualidade do ensino, alcançando a alfabetização na idade certa. A Instituição que aprovou a pesquisa não constará no manuscrito como forma de garantir o sigilo dos autores.

Assim, constatou-se ser mais apropriada, para a fidedignidade da pesquisa, a abordagem qualitativa do tipo etnográfico, por ter sido realizada com um grupo de professores e coordenadores de uma escola, especificamente, para essas análises, com a implementação de questionários.

A abordagem qualitativa apresenta-se como mais indicada para aproximar o pesquisador da experiência do indivíduo que é singular. De acordo com Minayo (2001), a abordagem qualitativa apresenta todos os requisitos e instrumentos para ser considerada e valorizada como um construto científico, permitindo contextualizar a experiência e a vivência de uma pessoa no âmbito da história coletiva e pela cultura do grupo em que ela se insere aspectos fundamentais para o cumprimento dos objetivos propostos nessa pesquisa. Ainda nesse sentido, a autora considera que toda compreensão guarda em si uma interpretação e isto requer o entendimento das contradições resultantes das relações de poder, das relações sociais de produção, das desigualdades sociais e de interesses.

Embora esta pesquisa possa apresentar um caráter descritivo, por termos sistematizado os dados por meio de descrições e percepções dos professores e coordenador de uma escola pública que participaram desta formação. Consideramos esta ser do tipo etnográfico por dar conta de aspectos inseridos na cultura organizacional. Dessa maneira, as categorias de análises consideraram aspectos dos conteúdos da formação, bem como dimensões das práticas de apoio à gestão dos professores alfabetizadores.

Além disso, o caráter descritivo permeia a pesquisa etnográfica que estuda a cultura de um grupo. A pesquisa etnográfica:

"abrange a descrição dos eventos que ocorrem na vida de um grupo (com especial atenção para as estruturas sociais e o comportamento dos indivíduos enquanto membros do grupo) e a interpretação do significado desses eventos para a cultura do grupo (GODOY,1995, p. 28)."

Para dar voz ao significado atribuído pela cultura escolar a esses grupos, durante formação do PNAIC em 2016, foram aplicados questionários a professores e coordenadores de uma escola do município de Bauru. O objetivo foi captar suas interpretações das ações desencadeadas no ambiente escolar depois da formação do PNAIC. A observação do processo de formação, bem como no cotidiano da escola, compõe o quadro do caráter etnográfico atribuído a esta pesquisa.

\section{RESULTADOS}

A instituição escola é datada historicamente, fruto de uma sociedade industrial visando a formação de mão de obra para a indústria. Segundo Coimbra (1989), é de fundamental importância para uma atuação mais crítica em educação repensar as funções que esta instituição exerce em nossa sociedade, e nos mitos da igualdade social e de oportunidades para todos, da neutralidade científica, mitos que colocam a escola acima da luta de classes e isolada de uma formação social específica.

Para Lombardi (2005), ao se pensar na conformação e no desenvolvimento da educação capitalista ou qualquer outra dimensão da vida social, faz-se necessário considerar o contexto em que surgem e se desenvolvem, especificamente nos movimentos contraditórios emergidos da luta entre burguesia e proletariado e que assumem as características próprias dos processos históricos de cada uma das formações sociais em articulação às relações e divisões do trabalho próprias do modo capitalista de produção de existência do homem.

Sacristán (2001), por sua vez, afirma que a escolaridade obrigatória passou a ser tomada como uma dimensão essencial e natural de nossas vidas, como qualidade acrescentada que condiciona o futuro, pois confere nova identidade social aos alunos na fase da infância ou da adolescência: crianças e adolescentes têm direitos a receber educação obrigatória, bem como referenciais para a construção da subjetividade para acreditarmos que somos e temos determinados valores em relação a outros.

Estas reflexões parecem ser necessárias considerando o fato de que a escola tem sido o lugar onde as crianças tem passado a maior do seu tempo. E, assim, da responsabilidade como educadores em refletir sobre a função da escola e os valores humanos tão necessários para uma sociedade mais democrática. Parece ser responsabilidade de todos a inquietude com as consequências de uma civilização globalizada, imersa no consumismo desenfreado e no individualismo crescente.

Percebe-se a partir de alguns autores, como Ferreira (2004), que quando se fala em gestão democrática, esta preocupação está nos valores humanos, em uma nova ética 
que se fundamente em fraternidade, solidariedade, justiça social, respeito, bondade e emancipação humana, no sentido de humanização e de formação de todas as pessoas que habitam este planeta.

Parece ser necessária a consciência de sermos cidadãos do mundo como apontado por Morin (2011), um pensamento policêntrico capaz de apontar o universalismo consciente da unidade/diversidade da condição humana, que nos leve à sabedoria de viver junto, que desenvolva a unidade, a mestiçagem e a diversidade contra a homogeneização e o fechamento, uma educação da ética planetária.

É neste cenário que carrega tanto os traços do passado como as demandas que emergem do mundo globalizado e tecnológico, que os educadores se encontram tentando pensar em como educar. Dessa maneira, como apontado por Tardif (2011), os sistemas de ensino ocidentais se encontram atualmente diante de exigências e desafios sem precedentes, exigindo-se cada mais que os professores sejam capazes de lidar com os inúmeros desafios que foram suscitados pela escolarização de massa em todos os níveis do sistema de ensino. A inovação parece ser um fator necessário à compreensão do processo histórico de democratização da escola pública e básica.

\section{1 - Inovação ${ }^{1}$ na gestão da prática pedagógica}

Para começar procuramos traçar um breve perfil, do que se dito a respeito da inovação. Ao tratar do tema das inovações educacionais observa-se que este tem sido tratado em estudos da UNESCO na América Latina norteados pelos princípios da Educação para todos e pela iniciativa "Comunidade de Aprendizagem". De acordo com um estudo desenvolvido pela UNESCO, em 2002, foram destacadas inovações vinculadas à abertura da escola para a comunidade em ações que promovem diferentes formas de participação comunitária e inovações vinculadas ao desenvolvimento de estratégias de ensino e de capacitação de docentes com a finalidade de responder às demandas colocadas pelas escolas em situação de pobreza.

No entanto, segundo Messina (2001), as pesquisas da UNESCO no âmbito da América Latina demonstram que este é um conceito complexo a ser definido, tendo sido, muitas vezes, tomada com um fim em si mesmo. Ainda, para a autora no campo educacional, o conceito e a prática da inovação tornou-se referência obrigatória a partir dos anos setenta, empregada no sentido de melhorar o estado das coisas vigente.

Este tema é adotado em grande parte como recurso nos processos de gestão e organização de empresas, um processo comum na história da gestão escolar. De acordo com a perspectiva de inovação definido pela OCDE (1992), trata-se de um termo polissêmico: "um conjunto de novos procedimentos e processos de melhoramentos de produtos e processos, novas formas de organização e gestão, novas formas e iniciativas originais na formação, qualificação, atualização e participação da mão-de-obra em todos os níveis". Esta definição abrange vários setores da sociedade desde a gestão à atualização de mão-de-obra e também o fato de ser um processo ou um novo procedimento.

Dessa maneira, parece ser consenso em tomar a inovação como algo que reorganiza o que já existe. Buscando o significado da palavra, Amorim (2015) nos

\footnotetext{
${ }^{1}$ Conceito de inovação
}

apresenta a origem da palavra inovação que vem do latim in e novare e tem como significado fazer algo novo, alterar ou renovar algo já existente, é um processo que se inicia com uma mudança naquilo que já está sendo realizado. Dessa maneira, a inovação não precisa, necessariamente, ser algo totalmente novo, pois pode ser o resultado de um processo que já vem sendo realizado.

Embora seja frequente o seu uso na administração de empresas esta também é objeto de estudo da sociologia. Buscando o significado dado pelo dicionário de Ciências Sociais observa-se que o conceito enfatiza o caráter qualitativo da inovação da seguinte forma: "qualquer pensamento, comportamento ou coisa que é nova por ser qualitativamente diferente das formas existentes" (apud REIS, 2001, p. 7). Além do caráter qualitativamente diferente que a inovação pode apresentar, é interessante notar que ela também pode ser um pensamento ou um comportamento, podendo ser algo não tangível.

Este caráter qualitativo apontado pelas Ciências Sociais talvez se aproxime da maneira como Wereber (1995, p. 266) conceitua o termo inovação, pois para o autor esta tem uma conotação valorativa "na medida em que significa: mudar para melhor, dar um aspecto novo, consertar, corrigir, adaptar a novas condições "algo" que está superado, que é inadequado, obsoleto etc.” De acordo com esta concepção, poderíamos pensar que quando a inovação acontece é porque algo que foi substituído ou modificado ficou obsoleto, por isso foi superado.

Observando as várias definições do que é a inovação ressalta-se o fato de não ser algo espontâneo, mas um processo que exige planejamento, componente estes ressaltados por Messina (2001, p.226) que identifica dois componentes que distinguem a inovação: “a) a alteração de sentido a respeito da prática corrente e b) o caráter intencional, sistemático e planejado, em oposição às mudanças espontâneas". Dessa maneira, reflete-se que existe uma prática corrente e um processo intencional que sistematiza e planeja ao contrário de mudanças espontaneístas.

No entanto, ao se falar em inovação educacional é importante destacar que, conforme apontado por Amorim (2015, p. 6), um processo inovador precisa ter "um alcance social, educacional, cultural, tecnológico e que possa ampliar as possibilidades existentes em relação à qualidade humana e material do que está em processo". Assim, a inovação é vista de acordo com a qualidade humana que se pretende melhorar no sentido de ampliar suas possibilidades.

Observa-se que é levantado a importância do fator humano do que está em processo e, sendo assim, o valor das relações sociais que produz e reproduz a existência humana e as inovações como processos socioculturais. De acordo com Maciel (2004, p. 9) "a produção, a socialização e o uso de conhecimentos e informações, assim como a conversão destes em inovações, constituem processos socioculturais e que tais práticas e relações inscrevem-se no espaço e na própria produção do espaço".

Ferretti considera que:

“a produção de inovações como a criação de respostas novas aos desafios oferecidos por um dado contexto, a partir da análise crítica do mesmo e das contribuições efetivas que tais respostas podem oferecer para enfrentar os desafios e produzir melhorias no objeto que é alvo de inovação. Por adoção crítica de inovações estamos entendendo a submissão das mesmas à análise retro-mencionada e 
sua adaptação às condições e exigências locais para fazer face aos desafios. Há que distinguir esta adoção da que também submete a inovação à crítica, mas apenas àquela crítica que se preocupa com as características eminentemente técnicas da mudança ou com suas dimensões estritamente psicopedagógica, minimizando ou desconsiderando, no todo ou em parte, as necessidades impostas pela realidade educacional ou pela realidade sóciopolítica (FERRETTI, 1995, p. 81).”

Vários fatores se inscrevem nos processos inovadores que não podem ser desconsiderados correndo o risco de permanecerem no nível da técnica e continuarem tão obsoletos quanto antes. Destaca-se a realidade educacional e a realidade sócio-política. Dessa maneira, consideramos necessária uma retomada de autores que abordam a inovação educacional e que a submetem a uma análise crítica que considera o todo.

Garcia (1995), considera que qualquer estudo sobre a inovação educacional deve estar associado a uma análise das condições de evolução histórica do país. Para este autor, nesta evolução, existe uma matriz externa que determina os rumos da educação, ficando evidente que muitas tentativas de inovações educacionais resultaram em tentativas desesperadas de modernizar, implantando no país o que dá resultados lá fora. Neste sentido, o autor aponta que estas tentativas resultam no que ele chama de transplantação cultural. Para ele, a transplantação cultural não resulta apenas em importar algo que é considerado bom, mas em atitudes e efeitos que se configuram em um contexto cultural. Ao importar modelos prontos impede-se a geração de soluções nativas, além de condicionar os educadores a esperarem por soluções mágicas.

Dessa maneira, para Garcia (1995), no Brasil a atitude clássica da inovação educacional operou mudanças apenas ao nível das metodologias de ensino, embora sem descartar a possibilidade de terem sido inovações, esta seria uma compreensão parcial do problema, pois elas precisariam ser analisadas no conjunto de outras mudanças levando-se em conta objetivos, valores e participação, e necessitam, ainda, de um clima maior de tolerância e de possibilidade de criação.

Destacam-se ainda, os estudos de Saviani (1995), no qual o autor analisa a inovação em relação às quatro concepções fundamentais de Filosofia da Educação que perpassam a evolução da organização escolar desde o momento em que a sociedade atual assume contornos definidos com a consolidação do poder burguês: (1. Concepção humanista tradicional, 2. Concepção humanista moderna, 3. Concepção analítica e 4. Concepção dialética).

$\mathrm{Na}$ concepção humanista tradicional, o autor considera sendo marcada pela visão essencialista de homem cabendo à educação conformar-se à essência imutável do homem, portanto, não há lugar para o tema inovação que acaba ocupando um lugar acidental. Saviani (idem, p. 20), coloca a seguinte questão: em relação a que algo pode ser considerado inovador? e a partir desta questão propõe o primeiro critério para se caracterizar a inovação "inovador é o que se opõe a tradicional". Contudo, o autor destaca que na concepção humanista moderna, a educação passa a centrar-se na criança e não mais no educador, naquele adulto antes considerado completo e acabado em oposição à criança considerada imatura e inacabada. Nesta perspectiva a experiência educativa ao invés de centrar-se no educador, centra-se no educando; ao invés de subordinar os métodos aos fins (o homem adulto), subordina os fins aos métodos. Portanto, nesta perspectiva, inovar será alterar essencialmente os métodos, as formas de educar.

$\mathrm{Na}$ concepção analítica de Filosofia da Educação, que trata do contexto linguístico prevalece a análise lógica da linguagem educacional, sendo assim o significado de "inovação" depende de uma análise do contexto linguístico em que ela é utilizada. Para o autor, em todos esses casos, a inovação permeia as dificuldades do processo educativo, sem referência ao contexto, sem questionar as próprias finalidades da educação. Neste sentido, na concepção dialética inovar será colocar a educação a serviço de novas finalidades, ou seja, a serviço da mudança estrutural da sociedade:

Dizer que algo é inovador porque se opõe ao tradicional significa aqui não apenas substituir métodos convencionais por outros. Trata-se de reformular a própria finalidade da educação, isto é, colocá-la a serviço das forças emergentes da sociedade (SAVIANI, 1995, p.24).

Estes autores permitem uma análise contextualizada das situações educacionais pelas quais o país passou, para que seja possível a partir do que já se realizou planejar, sistematizar inovações que visem a melhora da qualidade humana dos estudantes, professores e do país como um todo.

Consideramos relevante ressaltar que o professor brasileiro Paulo Freire trouxe conceitos inovadores para a educação tornando-se uma forte referência para os estudos educacionais entre eles sobre a importância da autonomia educativa, da humanização e da ética. Em seu livro Pedagogia da autonomia publicado no ano de 1996, Freire faz uma crítica ao ensino bancário, afirmando que ensinar não é transferir conhecimento, mas criar possibilidades para a sua construção. Freire (2011, p. 26) afirma que na relação do aprender é preciso respeitar os saberes que os educandos trazem, saberes construídos na prática comunitária, em um "processo que pode deflagrar no aprendiz uma curiosidade crescente, que pode torna-lo mais e mais criador". $\mathrm{Na}$ concepção do autor quanto mais se exerça a capacidade de aprender criticamente, mais se desenvolve a curiosidade epistemológica, o que exige a presença de educadores e educandos que tornem criadores, investigadores, inquietos, rigorosamente curiosos, humildes e também persistentes.

$\mathrm{O}$ respeito aos saberes dos educandos é um conceito inovador diante de um ensino autoritário, pois enfatiza a relação de respeito mútuo entre educador e educandos, pois ambos são sujeitos na relação do aprender. Esta questão pode ser observada por Resende (1989) que afirma que considerar o aluno, principalmente aqueles oriundos das classes populares alguém desprovido de cultura e alheio a todo espaço geográfico histórico, é consequência de um ensino baseado na 'des-historização', no estudo de um espaço geográfico em que o aluno não participa e que não ajuda a moldar, dessa forma, a verdade geográfica torna-se alheia a ele. Embora a pesquisa desta autora tenha como objeto de estudo o ensino de geografia, a atitude perante o aluno se estende a todas as disciplinas e na escola como um todo. Esta atitude reflete o histórico elitista em que a escola se firmou, pois, sendo uma vez voltada para uma determinada classe tem transformado devagar e a muito custo para outro público.

Este histórico é pertinente, pois remonta ao ensino da língua portuguesa escolar e na variedade elevada à categoria 
de norma culta em que se fundamenta. Geraldi (2006) aponta que o valor de uma variedade linguística é reflexo do poder e da autoridade que os seus falantes têm nas relações sociais e econômicas que fazem parte:

Sabemos que a forma de fala que foi elevada à categoria de língua nada a tem a ver com a qualidade intrínseca dessa forma. Fatos históricos (econômicos e políticos) determinaram a "eleição" de uma forma como a língua portuguesa. As demais formas de falar, que não correspondem à forma "eleita", são todas postas num mesmo saco e qualificadas como "errôneas, "deselegantes", "inadequadas para a ocasião etc" (GERALDI, 2006, p. 43).

No entanto, Bezerra (2007) ressalta que os avanços dos estudos linguísticos proporcionados pela Linguística contribuíram para descrever e explicar a língua e o processos de ensino/aprendizagem. Ainda, de acordo com o autor, as principais teorias que influenciam a metodologia de ensino nas últimas décadas do século $\mathrm{XX}$ e primeiros anos do século XXI são: a teoria sócio-interacionista vygotskana de aprendizagem, as de letramento e as de texto/discurso que trazem conceitos cognitivos, sóciopolíticos, enunciativos e linguísticos no processo de ensino/aprendizagem da língua. $\mathrm{O}$ autor ressalta que a concepção de aprendizagem que resulta da interação dialética de um sujeito com outros, enfatiza a importância da dimensão social no processo de desenvolvimento humano e, assim, a importância da escola no acesso ao conhecimento científico que deve proporcionar desafios, exigências e estímulos para que o intelecto conquiste estágios mais elevados de raciocínio.

A ênfase na interação social na construção do conhecimento coloca em questão, ainda, a necessidade de um currículo multiculturalmente orientado que não se baste em trabalhar conteúdos de forma isolada, mostrando apenas o produto e omitindo os processos, os conflitos envolvidos ao longo do percurso, questões importantes que poderiam ser problematizadas e discutidas em sala de maneira crítica.

Essa questão é levantada no texto publicado pelo Departamento de Políticas de Educação Infantil e Ensino Fundamental (DPE), vinculado à Secretaria de Educação Básica (SEB), do Ministério da Educação (MEC), "Indagações sobre o currículo: Currículo, Conhecimento e Cultura" ao se tratar dos conhecimentos curriculares. No texto afirma-se que um certo grau da descontextualização faz-se necessário, pois não se pode reproduzir na escola os conteúdos tais como funcionam no contexto de origem, porém uma forte descontextualização pode provocar a perda de sentido. Pois, o que se observa é que no processo de descontextualização dos saberes e das práticas costuma-se omitir o processo de produção, com todos os seus conflitos e interesses, dando uma impressão de pronto, acabado, perdendo-se a complexidade do trajeto.

No entanto, as mudanças colocadas como necessárias para a inovação educacional podem pressupor rupturas, não cabendo sempre uma reorganização do que antecede, principalmente, quando se fala em paradigmas e em emancipação. Neste sentido, Cunha (2003) considera a inovação em relação à dimensão emancipatória, dizendo que esta pressupõe a ruptura com modelos paradigmáticos. Esta ruptura não seria com a pretensão de se negar a história, mas sim, no sentido de partir desta para se trabalhar na mudança, na transformação. Ainda, para a autora, este posicionamento implica o reconhecimento da diferença para o gerir das relações sociais com os alunos.
Podemos entender que gerir as relações sociais com os alunos no sentido do respeito a diferença requer a ruptura com modelos paradigmáticos preconceituosos. Portanto, o reconhecimento da diferença é imprescindível para gerir as relações preconceituosas historicamente exigentes em nossa sociedade e que se perpetuam no ambiente escolar, seja por serem reforçados pelas próprias práticas escolares, por não serem trabalhados ou por outros motivos. De acordo com Freire (2011) as práticas preconceituosas de raça, de classe, de gênero se constituem em uma ofensa à substantividade do ser humano e negam radicalmente a democracia.

$\mathrm{O}$ fator democrático se insere neste processo de ruptura e de maior participação dos sujeitos nas decisões. Segundo Veiga (2003), a consolidação da educação básica e superior como direito de todos os cidadãos é objetivo do governo e da sociedade, não só garantindo o acesso e permanência dos estudantes, como também, deve estar articulado à construção do projeto político-pedagógico de qualidade que esteja comprometido com as necessidades sociais e culturais da população. Ainda, segundo a autora, a questão da inovação e do projeto político-pedagógico requer a preocupação fundamental enfrentada pelo sistema de ensino que seria melhorar a qualidade da educação pública para que todos aprendam mais e melhor. Dessa maneira, a questão da inovação é contextualizada com o objetivo de melhorar a educação pública do país, bem como ao nascimento de uma nova ciência não dicotomizante e fragmentada:

Considerando a inovação uma produção humana, parto da ideia de que suas bases epistemológicas estão alicerçadas no caráter emancipador e argumentativo da ciência emergente. A inovação procura maior comunicação e diálogo com os saberes locais e com os diferentes atores e realiza-se em um contexto que é histórico e social, porque humano. A ciência emergente opõe-se às clássicas dicotomias entre ciências naturais/ciências sociais, teoria/prática, sujeito/objeto, conhecimento/realidade. Tratase, portanto, de buscar a superação da fragmentação das ciências e suas implicações para a vida do homem e da sociedade (...). Os processos inovadores lutam contra as formas instituídas e os mecanismos de poder. É um processo de dentro para forma. Essa visão reforça as definições emergentes e alternativas da realidade. Assim, ela deslegitima as formas institucionais, a fim de propiciar a argumentação, a comunicação e a solidariedade (VEIGA, 2003, p. 274)

Neste sentido, que a inovação vem sendo abordada como uma demanda que deve nascer dos sujeitos como forma de emancipação. Segundo Medeiros (1997), a emancipação está intimamente ligada ao desenvolvimento da consciência moral, em um processo de desenvolvimento da heteronomia para a autonomia crítica-reflexiva. Ainda, para este autor, a emancipação envolve dimensões linguísticas, cognitivas e interativas, relaciona-se com libertação em relação a parcialidades, relaciona-se com o auto-entendimento para o ganho da autonomia, com a possibilidade de falar e ser ouvido, de expressar-se num nível comunicacional entre dois ou mais sujeitos, implica em estabelecer interação entre os diferentes agentes da fala.

Este processo de passagem da heteronomia para a autonomia é enfatizado por Rios (2007) afirmando que a formação moral se dá em meio as relações, pois a autonomia é conquistada a partir do exercício da reflexão, cabendo o recurso à ética para que a conquista da autonomia se realize. 
Dessa maneira, a inovação é enfatizada como fator emancipador que se dá em um processo de passagem da heteronomia para a autonomia e que ocorre em meio as relações sociais e, portanto, requer o domínio comunicacional para que seja possível estabelecer interações entre os agentes da fala, que podem ser um ou mais sujeitos.

Consideramos a afirmação de Freire (2011, p. 19) de que "não podemos nos assumir como sujeitos da procura, da decisão, da ruptura, da opção, como sujeitos históricos, transformadores, a não ser assumindo-nos como sujeitos éticos". Podendo complementar-se com a consideração de Ferreira (2004) de que se faz necessária a construção coletiva na escola e no mundo, de uma nova ética humana e solidária mediada pelo diálogo, a verdadeira forma de comunicação humana, para a superação das estruturas de poder autoritários.

Outro fator se faz necessário quando se fala em mudança. De acordo com Amorim (2015), a existência de uma capacidade de mudar, de transformar ou revolucionar o que está em processo é necessário para que os processos inovadores aconteçam.

O fator reflexão também é apontando como sendo necessário para a inovação, bem como a capacidade de mudar e de ser vista como uma oportunidade de melhorar a qualidade humana e profissional de todos. Segundo Libâneo (2001, p. 27), a mudança precisa ser vista como uma oportunidade de crescimento profissional e de fortalecimento da identidade profissional, desenvolvendo uma atitude "crítico reflexiva, isto é o desenvolvimento da capacidade reflexiva com base na própria prática, de modo a associar o próprio fazer e o processo do pensar". Portanto, requer a atitude de pensar sobre a própria prática de maneira que o fazer e o pensar estejam sempre associados.

No entanto, nem tudo acontece de maneira simplificada, justamente pelo fato de que os processos acontecem em meio as relações sociais com pessoas que são históricos e sociais. A gestão escolar acontece em meio a diversas situações que convivem tanto com a demanda pela mudança como com de resistência a ela, caracterizando um quadro de inércia institucional:

Especificamente no caso da instituição escolar, observa-se a convivência desses dois fenômenos - inércia e inovação -, uma vez que a necessidade de enfrentar os novos padrões de produtividade e competitividade impostos pelo avanço tecnológico vem proporcionando uma redescoberta da educação como componente essencial das estratégias de desenvolvimento. No entanto, a escola tem, em sua prática cotidiana uma estrutura cujo funcionamento reflete as grandes desigualdades na distribuição da renda e se tem apresentado ineficiente e 'injusta' na oferta de serviços educacionais (REIS, 2001, p. 57).

Neste sentido, consideramos relevante o estudo de Thurler (2011) que relaciona as estratégias de mudança com o sentido atribuído pelos professores, pois as mensagens dirigidas aos professores e aos grupos só teriam efeito quando entram em ressonância com seus pensamentos, valores, cotidiano, com toda uma cultura profissional e de estabelecimento escolar. Ainda, para o autor, o estabelecimento escolar é determinante no destino que será dado aos projetos de mudança, na construção do sentido que é acionado no momento que a mudança é proposta no campo do que é discutível, tendo como resultados fatores coerentes com à cultura e clima social que incluem aceitação, exame crítico e distanciamento cético, no qual as discussões serão estabelecidas em torno do objeto em questão.

Considera-se, ainda, que nem sempre as inovações precisam ser ações promovidas em larga escala, pois as ações do cotidiano são tão importantes para o desenvolvimento de qualquer processo. Mercado (1999, p. 34) exemplifica bem este fato afirmando que a "inovação na escola consiste em levar a cabo pequenas ações cotidianas que tornem possíveis as mudanças, a curto ou longo prazo, de maneira que beneficiem o processo de aprendizagem do aluno". Ainda, para o autor, na utilização de novas ferramentas tecnológicas, considera que o professor é quem pode provocar um processo inovador nas aulas. Para isso, o professor precisa ter interiorizado as novas tecnologias em processo pessoal, maduro e crítico e os alunos usuários com espírito crítico com a capacidade de analisar as implicações pedagógicas e reais de inovação que estes recursos possibilitam.

Especificamente sobre a formação do PNAIC, foi observado a problematização da estrutura e desenvolvimento administrativo da escola de ensino básico trazendo a gestão democrática como fator fundamental para alfabetização na idade certa. Este posicionamento em relação à importância da construção de uma gestão escolar democrática foi observado nessa Formação do PNAIC, onde foi enfatizado a importância da construção do Plano de Gestão que atenda às demandas das comunidades escolares e, por isso, a importância de ser construído. Observou-se, durante a formação, uma retomada da trajetória da administração escolar com os apontamentos das principais correntes determinantes da administração que trouxeram ao processo administrativo escolar objetivos, garantia de recursos, políticas de ação, quantidade e qualidade desejada de serviços e o uso de recursos. Estas correntes são apresentadas por Hora (2002) desde a teoria clássica criada no bojo da Revolução Industrial, representada por meio da administração científica de Taylor até a contemporânea que propõe o critério da efetividade, preocupa-se com a capacidade de promoção do desenvolvimento socioeconômico, com a melhoria das condições de vida humana, visando atingir objetivos sociais mais amplos que são externos ao sistema educacional, superando a pretensa neutralidade científica do sistema educacional.

Conforme afirma Amorim (2015), na escola ocorre uma fusão ideológica entre o planejamento administrativo, pedagógico e financeiro no qual a eficiência técnica segue preponderante à questão pedagógica, colocada em segundo plano. Conforme observado na formação do PNAIC, essa questão tem ainda como influência, o Positivismo que declara a ordem como método para se atingir o objetivo, estabelecendo hierarquias rígidas na divisão de tarefas.

Nesse conjunto de observações, notou-se a abordagem dos processos de homogeneização presente no ensino, bem como a confusão existente com os princípios de equidade, justiça, ou seja, de processos e condições igualitárias para pessoas diferentes. Isso porque, na sala de aula parece ser comum confundir equidade com igualdade e apresentar como solução um conteúdo único para todos os alunos. No entanto, a crença no mérito pessoal como ideal igualitário para a construção de uma sociedade mais justa é discutida por Patto (1999) como um discurso que surge no século XIX com a origem dos sistemas de ensino juntamente com teorias racistas baseadas no cientificismo. Sabemos que os ideais capitalistas reforçados por todo um aparato de Estado 
emergiram com o lançar o olhar para o lucro, com o produto, e não especificamente com valores humanos.

Parece que há uma insatisfação geral com os rumos tomados pela educação, bem como, conforme ressaltado por Amorim (2015), de um desejo generalizado por mudanças profundas nas concepções e no desenvolvimento das instituições de ensino de modo que se tornem dinâmicas, abertas e participativas.

Podemos observar a partir dos questionários aplicados na escola que, para todos os professores, há necessidade de inovações na escola. Os principais fatores que levaram a esta resposta foram: motivação para os estudantes, a inércia da educação; como estímulo e motivação para os alunos; pelo encantamento e motivação dos alunos; pelas dificuldades de aprendizagem; para atender à diversidade dos ritmos de aprendizagem.

Para complementar esta questão foi perguntado aos professores se sentiam dificuldades em promover algum tipo de inovação na escola. Um conjunto de seis professores declararam ter dificuldade, pois consideram haver falta de formação e comunicação; falta de material e grande número de alunos; e que as formações são descontinuadas. Outro conjunto de respostas, composta por dois professores, declararam não ter dificuldade em promover inovação devido à autonomia dentro da escola e possuir bons materiais pedagógicos; apoio de outros professores e da equipe gestora.

Ao tratar do discurso social e de resistência, Orlandi (2007) afirma que não se trata, em nenhum dos casos, de sentido de verdadeiro e sentido falso, mas, sim, do sentido imposto e do sentido recusado. Isso porque, os sentidos produzidos seriam marcados pela relação de forças, que instala o confronto, e não pela sinceridade, ou falsidade dos que os produzem.

De acordo com a percepção dos professores sobre a formação do PNAIC, foi observado que, tanto para os professores alfabetizadores quanto para o professor coordenador, trata-se de uma prática inovadora. Esses processos inovadores foram analisados pelos professores em três situações que se desdobram dentro do ambiente escolar: na prática pedagógica, na forma de abordagem dos conteúdos e, por fim, especificamente, nas metodologias e técnicas utilizadas.

Sobre a dificuldade na implementação no contexto de sala de aula do que é abordado na formação do PNAIC. Outro conjunto dos professores relataram não ter dificuldades e justificaram sua resposta alegando que a formação traz boas propostas que incentivam a ludicidade, a manipulação de objetos, a troca de experiências entre as crianças; as formações estão colaborando e inovando a prática escolar; as formações estão sendo claras; existe apoio de outros professores e gestão. Dois professores relataram terem dificuldade, devido a quantidade excessiva de alunos, a falta de material. Enquanto outro conjunto de professores respondiam e não justificavam sua resposta ou deixavam em branco.

Esse silêncio teria um significado? Orlandi (2007) afirma que, entre as formas de silêncio, existe a política do silêncio, que produz um recorte no que se diz e no que não se diz. Essa política do silêncio se inscreve na relação dito/não-dito e pode ser contextualizada sóciohistoricamente, em particular em relação ao "poder-dizer". Assumir o protagonismo nessas falas e respostas representa um caráter de reinvenção de uma prática internalizada no cotidiano dessa escola brasileira.

\section{2 - Inovação nas metodologias e técnicas utilizadas nos processos de alfabetização}

A relação observada entre a inovação e, especificamente, os processos de alfabetização decorrentes da formação do PNAIC, a gestão apontou a necessidade do uso da aula de trabalho pedagógico coletivo (ATPC) como foco para a organização do trabalho pedagógico em torno dos resultados apresentados pela Avaliação Nacional da Alfabetização (ANA). A ênfase nas avaliações externas e os resultados da ANA estão incutidas nas preocupações do gestor, apresentando-se na priorização que o planejamento do período de ATPC apresenta. No entanto, as discussões não têm como foco a análise dos resultados dessa avaliação e seus possíveis desdobramentos pedagógicos. Assim, esse espaço de formação continuada parece fazer prevalecer as questões organizacionais da escola, como os problemas relacionados à indisciplina dos alunos ou outros problemas gerenciais da escola. Amorim (2015) havia observado que a questão pedagógica é colocada em segundo plano para dar lugar a divisão de tarefas ou consolidação de tarefas que mais cuidam da aparência do que da essência da vida educacional. Trata-se de um importante espaço e lugar que tem se mostrado decisivo na criação de novas tecnologias sociais como podem ser consideradas as técnicas e metodologias do processo de ensino e aprendizagem (REIS e SENNA, 2016)

A gestão foi apontada como sendo necessária ao processo inovador das práticas cotidianas, no planejamento, acompanhamento e avaliação. Porém, esta ação tem sido focada mais para realizar a intermediação dos resultados apresentados pelas avaliações externas. Os resultados demonstram que a formação tem contribuído, especificamente, para a gestão da inovação nas práticas pedagógicas dos professores através de um processo de reorganização do seu trabalho com a alfabetização, ampliando a compreensão do próprio trabalho com alfabetização, com a utilização de jogos de alfabetização e de Matemática, por exemplo.

Essa questão pode ser verificada a partir da análise do portfólio da formação que apresenta o registro dos resultados da ANA. Foi demonstrada a realização de análise por níveis de proficiência em leitura, escrita e matemática com o detalhamento das habilidades a serem priorizadas e dos conteúdos a serem trabalhados.

\section{CONCLUSÃO}

A pesquisa foi delineada a partir do objetivo de investigar através das concepções e percepções dos coordenadores que atuam na alfabetização dos anos iniciais do ensino fundamental, se houve, de fato, um caráter de inovação nas suas práticas e, se resultaram na melhoria da qualidade do ensino, alcançando a alfabetização na idade certa.

Neste sentido, o levantamento de dados foi obtido a partir da análise dos referenciais teóricos sobre inovação, bem como um estudo aprofundado da proposta do PNAIC, leituras decorrentes dessas que tratam dos processos de alfabetização na idade certa e os resultados da ANA que servem como balizadores de conteúdo a serem desenvolvidos nos programas de formação. As observações 
dos distintos momentos, tanto de capacitação como implementação no cotidiano de um grupo de coordenador pedagógico e a equipe de professores de uma determinada escola seguiram o planejamento e foram complementadas com a realização de questionários com esse grupo de professores e coordenador de uma escola pública.

Consideramos importante dizer que serão necessárias análises mais aprofundadas para a compreensão do impacto inovador desta formação na gestão da prática pedagógica no desafio de melhorar a qualidade educacional no processo de alfabetização. Entretanto, esta pesquisa, dentro dos objetivos propostos e das possibilidades, apresentou resultados importantes para o início desta investigação.

A inovação foi apontada pelos professores e coordenadores como tendo repercussões na reorganização do trabalho pedagógico e na introdução dos materiais de jogos de alfabetização e de Matemática. A inovação apresentou-se, ainda, na introdução, no ano de 2016, com a gestão democrática implementada na Formação do PNAIC, configurando a visão de que os professores que atuam diretamente na alfabetização das crianças precisam do apoio de uma atividade-meio como fator fundamental no desafio para a alfabetização e para a melhoria da qualidade educacional e social do país.

O envolvimento da gestão nesta formação pedagógica é recente, sendo necessário percorrer um caminho no sentido da construção gestão democrática, bem como no planejamento das práticas pedagógicas com foco nas aprendizagens necessárias, observando que essas inferências foram possíveis pelas respostas dadas aos questionários, bem como pela análise do portfólio construído pela escola como modo de demonstração do que foi aprendido durante a formação.

Considerando o PNAIC como ação fundamentada no direito constitucional da criança em ter acesso à educação de qualidade, a introdução da gestão democrática como parte da formação no PNAIC/2016, analisada nesse artigo decorrente de um trabalho de conclusão de curso de graduação, implica uma expectativa de mudança. No entanto, observa-se que, na prática, persistem traços fortes da gestão tradicional e, ainda, a possibilidade de descontinuidade dessa política de formação tão importante para a garantia do cumprimento dos direitos de aprendizagem para todas as crianças e com qualidade.

\section{REFERÊNCIAS}

AMORIM, Antonio. Gestão escolar e inovação educacional: a construção de novos saberes gestores para a transformação do ambiente educacional na contemporaneidade. $37^{\text {a }}$ Reunião Nacional da ANPEd, UFSC - Florianópolis, 04 a 08 de outubro de 2015.

BAGNO, Marcos. Preconceito linguístico: o que é, como se faz. São Paulo: Edições Loyola, 1999.

BEZERRA, Maria Auxiliadora. Ensino de língua portuguesa e contextos teórico-metodológicos. In: DIONÍSIO, Ângela Paiva; MACHADO, Ana Rachel; BEZERRA, Maria Auxiliadora (Orgs.). Gêneros textuais \& ensino. Rio de Janeiro: Lucerna, p. 37-46, 2007.

CASTELLS, Manuel. A Era da Informação: economia, sociedade e cultura, vol. 3, São Paulo: Paz e terra, 1999, p. 411-439.
BRASIL. Constituição Federal de 1988. Promulgada em 5 de outubro de 1988. Disponível em <http://www.planalto.gov.br/ccivil_03/constituicao/constitui ção.htm>.

BRASIL. Estatuto da Criança e do Adolescente. Câmera dos Deputados, Lei no 8.069, de 13 de julho de 1990.

BRASIL. Lei de Diretrizes e Bases da Educação: Lei n ${ }^{\circ}$ 9.394/96 - 24 de dez. 1996. Estabelece as diretrizes e bases da Educação Nacional. Brasília: MEC, 1996.

BRASIL. Lei $\mathbf{n}^{\mathbf{0}} \mathbf{1 3 . 0 0 5}$, de 25 de junho de 2014. Aprova o Plano Nacional de Educação - PNE e dá outras providências. Diário Oficial da União, Brasília, DF, 26 jun. 2014, p. 1-7. Disponível em: <http://fne.mec.gov.br/images/doc/LeiPNE.pdf >. Acesso em: 21 dez. 2015.

Decreto Presidencial n. 6.094, de 24 de abril de 2007. Dispõe sobre a implementação do Plano de Metas Compromisso Todos pela Educação, pela União, em regime de colaboração com municípios, Distrito Federal e Estados. Diário Oficial da União, Brasília, 24 abr. 2007.

FERRETI, Celso João. A inovação na perspectiva pedagógica. In: GARCIA, Walter E. (Org.) Inovação Educacional no Brasil: problemas e perspectivas. $3^{\text {a }}$ edição. Campinas, SP: Autores Associados, p. 61-90, 1995.

GERALDI, João Wanderley. Concepções de linguagem e ensino de português. In: O texto na sala de aula - João Wanderley Geraldi, p. 39 - 46, 1985.

GARCIA, Walter E. Inovação Educacional no Brasil. $3^{a}$ edição, Campinas, São Paulo: Autores Associados, 1995.

GODOY, Arilda Schimidt. Pesquisa qualitativa: tipos fundamentais. Revista de Administração de Empresas. São Paulo, c. 35, n. 3, p. 20-29, Mai/Jun, 1995.

HAYDT, Regina Célia Cazaux. Avaliação do processo ensino-aprendizagem: as respostas das atividades encontram-se no final do livro. São Paulo: Ática, 1997.

HORA, Dinair. Leal. Gestão democrática da educação. 9 Ed. Campinas: Papirus, 2002.

LOMBARDI, José Claudinei. Educação, Ensino e Formação Profissional em Marx e Engels. Orgs: Demerval Saviani, José Claudinei Lombardi. Marxismo e Educação. Campinas, SP: Autores Associados: HISTEDBR, 2005.

MEDEIROS, Marilu Fontoura de. Paradigma de avaliação emancipatória e a ação supervisora: cidadania e espaço público. In: Nove olhares sobre a supervisão. Org: Celestino Alves da Silva Junior, Mary Rangel. Campinas, SP: Papirus, 1997.

MERCADO, Luís Paulo Leopoldo. Formação continuada de professores e novas tecnologias. Maceió: EDUFAL, 1999.

MESSINA, Graciela. Mudança e inovação educacional: notas para reflexão. Cadernos de Pesquisa, n. 114, novembro/ 2001 Cadernos de Pesquisa, n. 114, p. 225-233, novembro/ 2001.

MINAYO, Maria Cecília. Análise qualitativa: teoria, passos e fidedignidade. Ciênc. saúde coletiva vol.17 no.3 Rio de Janeiro Mar, 2012. 
MORIN, Edgar. Os sete saberes necessários à educação do futuro. Tradução de Catarina Sawaya. Revisão técnica de Edgard de Assis Carvalho. 6a edição. São Paulo: Cortez, Brasília: UNESCO, 2011.

ORLANDI, Eni Puccinelli. As formas de silêncio: nos movimentos dos sentidos. $6^{\mathrm{a}}$ edição, Campinas, SP: Editora da UNICAMP, 2007.

PARO, Vitor Henrique. A educação, a política e a administração: reflexões sobre a prática do diretor de escola. Educação e Pesquisa, São Paulo, v.36, n.3, p. 763-778, set./dez. 2010

PATTO, Maria Helena Souza. A produção do fracasso escolar: histórias de submissão e rebeldia. São Paulo: Casa do Psicólogo, 1999.

REIS, Márcia Lopes.; SENNA, Karina. Noridome. Feira de Ciências: tecnologia social para a formação do professor reflexivo. Revista SODEBRAS, v. 11, p. 166 - 170, 2016.

SACRITÁN, J. Gimeno. A educação obrigatória: seu sentido educativo e social. Porto Alegre: Artmed, 2001.

SAVIANI, Demerval. A Filosofia da educação e o problema da inovação em educação. In: GARCIA, Walter E. (Org.) Inovação Educacional no Brasil: problemas e perspectivas. $3^{a}$ edição. Campinas, SP: Autores Associados, p. 17-32, 1995.

TARDIF. Maurice. Saberes docentes e formação profissional. 12a edição. Petrópolis, RJ: Vozes, 2011.

THURLER, Monica Gather. Inovar no interior da escola. Tradução: Jeni Wolff. Porto Alegre: Artmed Editora, 2001.

VEIGA, Ilma Passos Alencastro. Inovações e projeto político-pedagógico: uma relação regulatória ou emancipatória? Cad. Cedes, Campinas, v. 23, n. 61, p. 267281, dezembro 2003.

\section{COPYRIGHT}

Direitos autorais: Os autores são os únicos responsáveis pelo material incluído no artigo. 


\title{
Revista SODEBRAS - Volume 14 \\ $\mathrm{N}^{\circ}$ 157- JANEIRO/ 2019
}

\section{EDUCAÇÃO DO CAMPO: A IMPORTÂNCIA DO PROFISSIONAL PEDAGOGO NAS EDUCAÇÃO DO CAMPO}

\section{EDUCATION OF THE FIELD: AN IMPORTANCE OF THE PROFESSIONAL PEDAGOGUE IN RURAL EDUCATION}

\author{
CARLOS LUIS PEREIRA ${ }^{1}$; EDSON RODRIGUES DOS SANTOS ${ }^{2}$ \\ 1 - UNIVERSIDADE CRUZEIRO DO SUL- SP; 2 - ESCOLA DE TEMPO INTEGRAL- MOACIR \\ AVIDOS- VITÓRIA-ES \\ carlosluispereira_331@hotmail.com; edson_es@oi.com.br
}

\begin{abstract}
Resumo - Neste estudo o objetivo foi elucidar sobre o papel primordial do profissional pedagogo em escolas da Educação do Campo. O problema de investigação foi verificar se a presença do pedagogo nos territórios educativos campesinos assegura os princípios educativos desta modalidade de ensino? Em relação à delimitação metodológica o estudo enquadra-se dentro da abordagem da pesquisa qualitativa e dentro dos procedimentos da investigação do tipo do estudo de caso. E, como técnicas de coletas de dados recorreu-se ao uso de entrevistas e observações participantes. Um dos resultados importantes mostrou que a presença deste profissional promoveu a articulação pedagógica entre as diretrizes para esta modalidade de ensino como os saberes destes sujeitos sociais coletivos. Conclui-se que a formação inicial do profissional pedagogo capacita-o para o cumprimento da legislação específica da escola do campo.
\end{abstract}

Palavras-chave: Educação do Campo. Pedagoga. Legislação.

Abstract - In this study the objective was to elucidate the primordial role of the professional pedagogue in schools of the Field Education. The research problem was to verify if the presence of the pedagogue in the peasant educational territories ensures the educational principles of this modality of education? Regarding methodological delimitation, the study falls within the qualitative research approach and within the investigation procedures of the case study type. And as data collection techniques we used the use of interviews and participant observations. One of the important results showed that the presence of this professional promoted the pedagogical articulation between the guidelines for this modality of teaching as the knowledge of these collective social subjects. It is concluded that the initial training of the educational professional enables him to comply with the specific legislation of the rural school.

Keywords: Education of the Field. Pedagogist. Students. Schools.

\section{INTRODUÇÃO}

A Educação do Campo é uma realidade na educação brasileira, esta modalidade de ensino tem respaldo nos documentos educacionais atuais, em particular da atual Lei de Diretrizes e Bases da Educação Nacional n 9394/96, nas Diretrizes Operacionais Básicas para Escolas do Campo (2002) e das Diretrizes Complementares, Normas e Princípios para Educação no Campo (BRASIL, 2008) constam nestes marcos legais que o ensino em territórios educacionais campesinos deve atender as exigências de específico e diferenciado e, ainda com processos próprios de ensino e aprendizagem ancorado na Pedagogia da Terra, onde ocorra o respeito dos saberes dos sujeitos sociais campesinos, suas memórias coletivas, ciência e cultura.

De acordo com a acepção dos teóricos de referência nacional desta modalidade de ensino a citar Roseli $\mathrm{S}$. Caldart, Mônica Molina, Gaudêncio Frigotto, Erineu Foerste, Miguel G. Arroyo, Adelar Pizzetta, Isabel B. Pereira e Laís M. Sá, todos teóricos citados defendem o projeto de educação no campo ancorado no marco conceitual da pedagogia da autonomia e do oprimido do mestre Paulo Freire, objetivando uma educação em territórios campesinos que promova uma educação: emancipadora e libertadora.

O projeto da Educação do Campo brasileira anseia por uma educação que reconheça e fortaleça as memórias coletivas dos povos campesinos em todo o processo educativo, porque estes sujeitos sociais possuem saberes que historicamente foram transmitidos pela oralidade de geração em geração com o objetivo de manutenção de suas identidades socioculturais.

$\mathrm{Na}$ afirmativa de Caldart (2012) a luta histórica destes povos pelo direito à terra e, por uma educação contra hegemônica e de resistência ao modelo capitalista e que seus saberes tradicionais sejam reconhecidos e valorizados pelo currículo, afim de reproduzir suas identidades socioculturais e educacionais

Nesta mesma direção o posicionamento político e ideológico de Molina (2017) os homens e mulheres do campo são detentores de saberes da terra e, buscam por uma escola que valoriza, reconheça e valida no currículo praticado estes conhecimentos da terra, sendo assim uma das atribuições da escola ressignificar os conhecimentos científicos escolares tendo como ponto de partida os conhecimentos do cotidiano dos alunos em todo processo educativo em toda a Educação Básica.

A centralidade deste trabalho foi em apresentar no decorrer do texto a importância do profissional pedagogo nas escolas do campo, principalmente no atual contexto em que muitas encontram-se com: precárias infraestrutura, corpo docente com formação insuficiente, falta de materiais didáticos específicos e evasão escolar sendo assim neste contexto que o profissional pedagogo desempenha o papel 
de articulador pedagógico de todo o processo de ensino e aprendizagem.

Tivemos como proposição desta comunicação visa demonstrar que o profissional pedagogo exerce função primordial no sentido de intermediar, organizar e sistematizar todo o processo educativo.

A justificativa para este trabalho está embasada nos dados do Programa Nacional da Educação do Campo (PRONACAMPO) implementado em 2013 pelo Governo Federal para dar suporte a Educação do Campo, conforme dados deste órgão há um quantitativo importante de alunos do sexo masculino que estão fora da escola e, ainda não concluíram o Ensino Fundamental II, este número é menor entre as mulheres. Dados do Pronacampo aponta que um quantitativo importante são alunos do sexo masculino que abandonam à escola devido ao trabalho com seus pais nas lavouras de café, na pesca e entre outras atividades para ajudar no sustento das suas famílias. Neste sentido o pedagogo tem inicialmente deslocado ao local de trabalho destes alunos e, propondo dentro da legislação flexibilização de horários de aulas conforme é previsto na Pedagogia da alternância para viabilizar a permanência destes alunos na escola (BRASIL, 2013).

$\mathrm{O}$ trabalho justifica-se pela presença do pedagogo na escola, porque este ator educacional tem como uma de suas atribuições estudar as legislações atuais específicas da Educação do Campo e, em seguida discutí-las com toda comunidade escolar.

A delimitação do estudo teve como abrangência investigar a relevância do profissional Pedagogo na escola do campo.

Em relação ao problema de pesquisa à delimitação foi investigar: Como a presença do profissional pedagogo nesta escola do campo tomada para pesquisa corrobora para o cumprimento dos princípios norteadores estabelecidos pelos documentos educacionais legais atuais?

Coloca-se como hipótese tendo como arcabouço teórico nas Diretrizes Curriculares para Licenciatura em Pedagogia (BRASIL,2006) que o pedagogo na Educação do Campo possibilita a articulação de todo o processo de ensino e aprendizagem.

No desdobramento do trabalho anunciamos como objetivo geral: Demonstrar no decorrer no texto a importância do profissional pedagogo na Educação do Campo.

\section{REFERENCIAL TEÓRICO}

A identidade da escola do campo é definida pela sua vinculação às questões inerentes à sua realidade, ancorandose na temporalidade e saberes próprios dos alunos e de todos dos sujeitos sociais campesinos, os homens e mulheres da terra. Estes atores sociais possuem saberes próprios usados no contexto social e cultural, os campesinos carregam consigo memórias coletivas transmitidas de geração em geração, são povos que trazem a marca da resistência contra um modelo econômico capitalista e buscam por uma escola contra hegemônica, esta que atenda suas especificidades (BRASIL, 2002; 2008) e (BRASIL, 2012).

$\mathrm{Na}$ perspectiva teórica de Caldart (2012) na qual partilhamos o mesmo pensamento a Educação do Campo não significa um contexto educativo de atraso e sim de um novo paradigma educacional de viés contra o modelo atual capitalista vigente, e para a autora somente uma educação com Projeto Pedagógico precisamente definido com uma proposta libertadora e emancipadora social através da educação poderá fortalecer a identidade dos povos campesinos.

Revisitando os documentos legais atuais avançados que respaldam a Educação do Campo, é consensual a afirmação que esta modalidade de ensino é uma ação afirmativa que visa à correção da desigualdade histórica as populações campesinas (quilombolas, ribeirinhos, meeiros, extrativistas, garimpeiros, assentados, reassentados, sem teto, etc.) ao acesso à Educação Básica de alta qualidade assegurada pela atual Constituição. Cabe ressaltar que apesar da visibilidade das escolas do campo atualmente como aponta o Pronacampo (2013) centenas de escolas de campo têm sido fechadas e seus alunos alocados em escolas do meio urbano que não assegura os saberes dos alunos campesinos.

Na vertente de Molina e Sá (2014) tem afirmado que a proposta da Educação do Campo enraíza-se na história dos movimentos sociais, das lutas das populações do campo, pelo direito à terra, ao reconhecimento de sua cultura, costumes, saberes, modos de viver, e pelo desenvolvimento dentro da sustentabilidade nos territórios campesinos.

$\mathrm{Na}$ afirmativa de Frigotto (2012) respaldada nos escritos de Freire (2017) sobre a Pedagogia da Autonomia, é que a Educação assegurada em territórios educativos campesinos tenha um projeto de educação que fortaleça a realidade específicas das populações campesinas e neste sentido a presença do pedagogo pode contribuir para elucidar a todos atores educacionais e sociais do papel de uma escola de campo no atual cenário político e capitalista brasileiro, principalmente no que tange à agricultura familiar, um dos pilares desta população.

No paradigma de Camacho (2014) um dos desafios atuais da escola do campo brasileira tem sido no descompasso entre o preceito legal e a realidade vivenciada na maioria das escolas campesinas do Brasil, para o autor ainda tem escolas que não possuem Projeto Político Pedagógico (PPP) ou as vezes no PPP praticado tem importante desacordo e o pedagogo devido à formação inicial contemplar disciplinas pedagógicas e da legislação, consegue no seu trabalho intermediar com os professores.

Seguindo o raciocínio deste mesmo autor apresentado em sua tese de doutorado, a luta contemporânea dos povos campesinos é por uma escola que contempla a emancipação humana do sujeito através do conhecimento crítico e reflexivo e contextualizado para o aluno campesino. $\mathrm{O}$ autor ainda advoga pela efetivação dos pressupostos teóricos, metodológicos, políticos e ideológicos e da produção e materiais didáticos específicos para os alunos campesinos.

Diante da afirmação de Camacho (2014) entendemos a importância do profissional pedagogo para articular todo este processo dentro do contexto escolar, porque ele é o profissional respaldado pelo Ministério da Educação com formação adequada para exercer com alta qualidade essa função.

$\mathrm{Na}$ vertente teórica de Santos (2018) atualmente no cenário educacional brasileiro a Educação do Campo tem tido importante visibilidade e documentos legais avançados de garantia para uma educação que atenda as especificidades desta modalidade de ensino em contrapartida, conforme expõe a autora ainda há baixa qualificação docente em todas as áreas, fechamento de escolas, falta recursos materiais, para a autora é diante deste quadro que se faz necessário a presença do profissional com licenciatura em Pedagogia 
para propor aos professores estratégias de ensino adequadas as particularidades do território educacional campesino e ainda que o mesmo promova para os professores cursos de formação continuada, visando assegurar uma educação inspirada na emancipação social e humana dos sujeitos campesinos.

Na acepção de Molina (2017) é emergente aos cursos de licenciatura em Educação do Campo promover políticas consistentes de formação de professores para atuar nesta modalidade de ensino sobre a discussão da presença do profissional em Pedagogia engajado nos movimentos sociais para promoção de uma educação libertadora para os povos campesinos, através de uma educação de alta qualidade.

Ainda na colocação desta teórica um dos desafios atuais tem sido a formação de professores em nível de Licenciatura em Educação do Campo comprometidos com os princípios estruturadores desta modalidade de ensino.

Seguindo essa mesma ideia Caldart (2012) advoga a favor do profissional pedagogo afirmando que o mesmo tem a intencionalidade e a formação para ajustar os problemas pedagógicos da escola do campo, entre eles um dos mais graves são que os livros distribuídos no Programa Nacional do Livro Didático (PNLD) que não tem como objetivo atender aos alunos campesinos, tem sido distribuídos para as escolas do campo, colaborando para a dissolução da identidade dos alunos do campo. Sendo assim o profissional pedagogo poderá desempenhar a função de junto com os professores a elaboração de materiais didáticos.

Dialogando com Chaves e Foschiera (2014) um dos desafios da Educação do Campo consiste na dualidade entre o cumprimento do currículo de referência nacional comum determinado pelo MEC e assegurar na parte diversificada do currículo conhecimentos específicos de acordo com a realidade de cada povo campesino, Para o autor a presença do profissional pedagogo é fundamental para auxiliar o professor apresentando metodologias variadas com adequações à Escola do Campo e o processo da transposição didática interna, quer dizer àquela realizada pelo professor em sala de aula. Essa tessitura realizada por este profissional aproxima com os princípios desta modalidade de ensino.

Parafraseando Nickel (2016) e Vighi (2013) o profissional pedagogo inserido na escola do campo atua como agente de mudança da prática educativa dos professores que tiveram na formação inicial um quantitativo insuficiente de disciplinas de cunho pedagógico em comparação com as da área específica da formação. E, para os autores na qual concordamos há carência no Brasil de professores do campo que atuam na modalidade de ensino da Educação do Campo, há um número importante de professores que nunca tiveram experiência nesta modalidade de ensino em todo processo da formação inicial, inclusive no estágio supervisionado e, estão atuando nesta modalidade de ensino por diversos motivos que não serão apresentados neste estudo.

Nessa mesma perspectiva Brabo, Cordeiro e Milanez (2012) ancorados legalmente nas Diretrizes Curriculares Nacionais para Licenciatura em Pedagogia (BRASIL, 2006) apontam sendo uma das atribuições deste profissional zelar pelo processo pedagógico e metodológico e, articular os conhecimentos científicos escolares com os culturais trazidos pelos alunos, além da sensibilização afetiva com todos alunos, visando melhoria na aprendizagem. E de acordo com estes autores o profissional pedagogo na formação inicial é assegurado na organização curricular competência humana, pedagógica, didática e metodológica.

A atual Lei de Diretrizes e Bases da Educação Nacional aponta que o profissional Pedagogo na formação inicial é assegurado saberes disciplinares e curriculares para o mesmo atuar como organizador do processo de ensino e aprendizagem, intermediando, organizando e sistematizando o cotidiano educativo escolar.

$\mathrm{Na}$ afirmativa de Saviani (2012) e Neri (2014) o profissional pedagogo nas escolas públicas, na qual está inserida a educação do campo tem como principal atribuição a organização do trabalho pedagógico na perspectiva de um trabalho coletivo entre alunos, professores, gestor e familiares. No que se refere à Educação do Campo segundo Casas e Lima (2012) acrescenta que uma de suas principais atribuições está em apresentar aos professores possibilidades de estratégias metodológicas contextualizadas com os conhecimentos cotidianos dos alunos campesinos, que trazem ao entrar na escola.

Sobre a escola do campo, na preposição de Caldart, Molina e Arroyo (2012) a sua função é valorizar, reconhecer e validar os saberes socioculturais dos alunos e usá-los como ponto de partida para o ensino dos conhecimentos científicos escolares de base nacional comum e, principalmente de uma escola que atenda as especificidades de cada território campesino.

Sobre essa questão acima colocada, na concepção de Neri (2014) da qual alinhamos nosso pensamento o profissional pedagogo no contexto é o único profissional na escola na qual a formação inicial contemplou saberes disciplinares e curriculares para organizar e intermediar o processo de ensino e aprendizagem.

$\mathrm{Na}$ posição de Casas de Lima (2012) além das atribuições citadas para este profissional, as autoras pontuam que ao pedagogo na educação do campo deve ter a intencionalidade de socializar o conhecimento científico de forma integralizada, contextualizada e, com adaptações curriculares de acordo com as especificidades da realidade do território campesino.

Conforme as autoras a educação do campo o pedagogo é o profissional que dialoga teoricamente com o marco: conceitual, pedagógico e político da escola do campo, porque o mesmo tem papel fundamental na elaboração do Projeto Político Pedagógico (PPP) no sentindo de organizar com toda à comunidade escolar a sua construção e reconstrução permanente.

Na visão de Machado (2009) o pedagogo na educação do campo é fundamental devido à falta de motivação dos alunos frente aos estudos, devido a inserção precoce no trabalho e em segundo pela falta de reconhecimento da escola de seus saberes tradicionais e, o pedagogo tem como competência assegurar práticas educativas dos professores que despertem nos alunos o incentivo e interesse para a aprendizagem.

Seguindo essa mesma direção na vertente teórica de Arroyo, Molina e Caldart (2012) o pedagogo da escola do campo deverá objetivar o desenvolvimento integral do aluno, atuando junto e assessorando o professor, avaliando, planejando e coordenando o desenvolvimento do processo de ensino e aprendizagem, ao propiciar aos docentes variadas estratégias metodológicas adaptadas com os alunos campesinos conforme indica nos documentos legais para esta modalidade de ensino. 
Concordando com os teóricos acima citados, Romani e Batista (2014) os documentos educacionais atuais, em particular na atual LDB em seu artigo 28 que na educação do campo seja assegurado as adaptações curriculares necessárias à sua adequação às peculiaridades da vida campesina de cada região. Assim sendo necessário adequações nos conteúdos curriculares, afim de atender as necessidades e interesses dos alunos campesinos.

$O$ pedagogo na educação do campo diante da autonomia prevista pela legislação (LDB) em relação à organização escolar, principalmente do calendário escolar às fases do ciclo agrícola e às condições climáticas essas adaptações como advoga Romani e Batista (2014) não são simples de serem implementadas, porém necessárias para propiciar permanência dos alunos na escola e um ensino significativo para os alunos e, compete a este profissional a organização escolar levando em consideração as particularidades citadas.

De acordo com a exposição teórica acima, Feiges (2007) aponta a centralidade do profissional pedagogo na escola do campo porque compete a este ator educacional acompanhar alunos e professores no processo de ensino e aprendizagem, visando formar cidadãos emancipados em decorrência de um ensino contextualizado para alunos campesinos.

A própria Caldart (2012) afirma que a educação do campo não é uma educação atrasada, o campo não significa atraso". Na fala da autora o ensino no contexto campesino deve atender aos princípios de um ensino específico e diferenciado, que visa a valorização da cultura dos alunos, que respeite a às organizações sociais e o conhecimento por ela produzido, de uma educação de alta qualidade; Uma educação do campo no campo; Educação no campo como produção de culturas; Educação no campo na formação dos sujeitos e Educação no campo como formação humana para o desenvolvimento sustentável e para o uso das tecnologias presentes nos territórios campesinos e a Educação no campo que respeite as características do campo e para promover o cumprimento destes princípios se faz necessário a figura do pedagogo.

\section{ENCAMINHAMENTO METODOLÓGICO}

Neste estudo teve-se como delimitação metodológica a pesquisa dentro da abordagem qualitativa; em relação aos procedimentos o estudo enquadra-se na pesquisa do tipo estudo de caso qualitativo seguindo as orientações de Yin (2015). Sobre as técnicas de coletas de dados foram selecionadas as entrevistas estruturadas e das observações participantes; Em relação aos sujeitos da pesquisa o estudo foi realizado com uma pedagoga, à pesquisa de campo ocorreu no primeiro e segundo semestre letivo de 2018, precisamente de março à novembro nos turnos matutino, vespertino e noturno. $\mathrm{O}$ ambiente da pesquisa foi numa escola estadual do Norte do Estado do Espírito Santo, Como instrumento de coleta de dados os mesmos foram transcritos em diário de bordo e, em seguida digitalizados. Sobre a análise dos dados recorreu-se a metodologia qualitativa da análise do conteúdo proposta pela Bardin (2011).

\section{APRESENTACÃO DOS RESULTADOS}

A pesquisa revelou durante as observações participantes no que se refere ao profissional pedagogo sujeito da pesquisa sua práxis estava alinhada com os documentos legais atuais para a Educação do Campo;

Verificou-se nas entrevistas com os professores que a função pedagógica desempenhada pela pedagoga está de acordo com as orientações das Diretrizes Curriculares Nacionais para a Licenciatura em Pedagogia, entendemos que estes professores conseguiram identificar a importância deste profissional na articulação do trabalho pedagógico escolar.

Ao examinar o PPP desta escola do campo pesquisada e observar sistematicamente, a pedagoga no seu ofício pude observar que sua prática alinhada com a proposta deste documento que estabelece um ensino específico e diferenciado e ainda que atenda as especificidades dos povos campesinos daquele território educativo;

Um resultado consistente verificado foi à visitação da pedagoga semanalmente as casas ou mesmo nas lavouras para tentar resgatar os alunos evadidos da escola, observouse que a mesma possui uma ficha de acompanhamento de alunos evadidos e com afetividade social têm buscado resgatá-lo. Ainda ao examinar os fichamentos individuais a pedagoga acolhe dos alunos as suas possibilidades de retornarem à escola e, nas reuniões pedagógicas socializa com os professores, estes elaboram junto com a pedagoga estratégias que atendam a estes alunos, em sua maioria do sexo masculino.

$\mathrm{Na}$ entrevista com os professores de todas as áreas de conhecimentos o discurso de $100 \%$ foi da importância da pedagoga na escola no sentido de dar suporte pedagógico e metodológico as suas necessidades;

Foi perguntado à pedagogo como a mesma havia adquirido subsídios teóricos para atuar na Educação do Campo, a mesmo revelou que realizou formação continuada algumas dela com recurso próprio e outros com apoio dos órgãos contratantes.

Ao observar a entrada na escola de um professor que revelou nunca ter tido experiência com a Educação do Campo, pedagoga inicialmente disponibiliza os documentos legais atuais desta modalidade de ensino e em seguida livros específicos entre eles o dicionário da Educação do Campo.

Foi citado pela pedagoga que a escola está em processo de elaboração de materiais didáticos contextualizados para a Educação do Campo e citou que o livro didático ainda tem sido o principal recurso didático dos professores, porém a mesma nos encontros pedagógicos semanais ,orienta aos professores para realizar adequações tendo como parâmetro o contexto social e cultural dos alunos daquele território educativo campesino, ela apontou que os professores têm mostrado dificuldade para confecção de materiais adequados aos alunos campesinos.

Nas observações realizadas verifica-se precária infraestrutura da escola com ausência de amplas salas de aula, laboratórios, quadras poliesportivas, biblioteca com número expressivo de acervos e falta de uma sala de informática.

Do discurso da professora pedagoga foi que ao examinar as atividades propostas pelos professores se faz necessário a sua intervenção no sentido de adequar conforme os princípios da Educação do Campo, ainda relata que cerca de $90 \%$ dos professores atuam em escolas do meio urbano e se faz necessário a desconstrução da prática educativa que não atende ao ensino específico e diferenciado que venha atender as necessidades e especificidades dos territórios educativos campesinos. 
No discurso dos professores na formação inicial e continuada há domínio insuficiente para trabalhar com a Educação do Campo conforme estabelece as diretrizes atuais vigentes para essa modalidade de ensino.

Nas observações sistemáticas do ofício da pedagoga, a mesma explicitou aos professores a fragilidade dos mesmos acerca do cumprimento dos princípios norteadores da Educação do Campo, observado nas atividades dos cadernos dos alunos e nas avaliações institucionais. Uma estratégia proposta e teve aceitação de $100 \%$ dos professores que teve $100 \%$ de aceitação dos professores foi o estudo da obra de Paulo Freire A Pedagogia da Autonomia e discussão da mesma em grupo, para essa atividade os alunos tiveram um mês para preparação para apresentação em grupos, no mês seguinte a obra indicada foi Pedagogia do Oprimido.

Seguindo essa mesma direção no discurso dos professores após o estudo dos escritos de Freire (2017) indica que os mesmos aumentaram os subsídios teóricos sobre o marco conceitual que sustenta essa modalidade de ensino de resistência e contra hegemônica e ainda que visa a emancipação humana, social e educacional por meio de uma educação libertadora.

\section{APRESENTAÇÃO DAS DISCUSSÕES}

Conforme estabelecido pelos documentos educacionais atuais para a Educação do Campo dentre eles destaca-se as Diretrizes Operacionais Básicas para Escolas do Campo (BRASIL,2002),(BRASIL,2008) das Diretrizes Curriculares Nacionais para a Educação Básica (BRASIL, 2012) durante as observações da prática da pedagoga investigada estava alinhada de acordo com as orientações dos referidos documentos citados;

No discurso dos professores entrevistados $100 \%$ revelaram que a ação da pedagoga na escola corrobora para o cumprimento do Projeto Político Pedagógico específico da referida escola e nos aportes teóricos de Molina (2017) uma das atuais preocupações políticas têm sido a formação de professores do campo que reconheça, valida e reproduza os saberes dos sujeitos do campo, afim da manutenção e reprodução de suas identidades socioculturais.

O Projeto Político Pedagógico de cada território educativo campesino é de responsabilidade coletiva de todos os sujeitos sociais e, conforme aponta Ramos (2013) em seus trabalhos têm mostrado o descompasso entre o currículo prescritivo com o currículo praticado, porém na observação do ofício da pedagoga nota-se inicialmente seu conhecimento advindo da formação inicial acerca dos marcos teóricos, legais e conceituais que norteiam esta modalidade de ensino que são colocados em prática na sua ação.

Os dados do Pronacampo (2013) mostram importante preocupação no que se refere a gênero da expressiva evasão dos homens da escola e poucas políticas têm sido implementadas para sanar este problema. $\mathrm{Na}$ proposição de Brabo, Cordeiro e Milanez (2012) a competência humana faz parte da formação do profissional pedagogo e nesta escola verifica-se que uma rotina da pedagoga foi $o$ deslocamento a casas dos alunos evadidos para propor alternativas para o retorno nos mesmos à escola em seguida nota-se que a mesma como defende Freire (2017) propõe a dialogicidade aos professores para propiciar novas estratégias metodológicas visando promover o interesse destes alunos para retornar as salas de aula, e esta ação tem tido resultados significativos.
As Diretrizes Curriculares Nacionais para Licenciatura em Pedagogia (BRASIL,2006) em seu artigo $n^{\circ} 2$ estabelece como uma das atribuições do Pedagogo atuar como mediador pedagógico da escola, e constata-se que a pedagoga investigada cumpriu tal orientação legal.

Os professores entrevistados revelaram que a formação continuada tem sido assegurada dentro do contexto escolar nas ações socioeducativas promovidas pela pedagoga, para responder ancorar este expressivo resultado Molina (2017) e Caldart (2012) entram em consonância na defesa de formação de professores do campo para atuar no e para o campo, para elas o cumprimento deste preceito legal desta modalidade de ensino constitui um dos atuais desafios dos 42 cursos de Licenciatura existente no Brasil e, a viabilização deste sujeito campesino se faz necessário a presença do pedagogo $\mathrm{n}$ articulação pedagógica de todo processo educativo.

\section{CONCLUSÃO}

O estudo mostrou que a Educação do Campo o objeto de estudo que norteou a investigação deste estudo trabalho que teve como foco elucidar a importância do profissional pedagogo na escola do campo, e o problema de pesquisa é resolvido ao elencar-se no decorrer no texto evidenciou que este profissional devido seus saberes disciplinares e curriculares, profissionais e experienciais contribuem significativamente para o cumprimento das diretrizes específicas para essa recente modalidade de ensino no Brasil.

Sublinhamos que este profissional na formação inicial tem como função central articular todo o processo pedagógico da escola e ainda desempenha o papel de resgatar os alunos campesinos para dentro da escola, devido a sua competência humana e afetividade social com alunos e professores.

Ainda foi destacado no trabalho que o profissional pedagogo configura-se como o elo entre aluno-professor e, todas as ações da prática educativa dos professores são coordenadas por meio dos seus saberes profissionais específicos adquiridos na formação inicial.

$\mathrm{O}$ trabalho atinge o objetivo ao decorrer do texto ao demonstrar com embasamento teórico a importância deste profissional na Educação do Campo, visando alta qualidade do processo educativo como direito dos povos campesinos assegurado pelos documentos legais atuais específicos para esta modalidade de ensino citados no decorrer do texto.

Uma das limitações para o estudo foi no deslocamento semanal do pesquisador para as pesquisas de campo e em segundo para os registros com precisão das entrevistas.

A relevância social do trabalho foi mostrar para os gestores e secretários de educação que o excelente funcionamento de uma escola do campo em muito depende deste profissional capacitado para efetivar no currículo real uma educação do campo que atenda aos interesses dos povos campesinos.

A contribuição do estudo foi apresentar aportes teóricos que discorreu especificamente sobre o papel do pedagogo nos territórios educativos campesinos e ainda que propomos que nos cursos de Pedagogia venham a discutir por meio de disciplinas ou seminários o protagonismo do profissional pedagogo nas escolas do campo. 


\section{REFERÊNCIAS}

ARROYO, M.G.; CALDART, R.S.; MOLINA, M.C. Dicionário da educação do campo. Rio de Janeiro. Editora: Expressão Popular, 2012.

BARDIN, L. Análise do conteúdo. São Paulo. Editora: Edições 70, 2011.

BRASIL. Diretrizes Operacionais Básicas para Escolas do Campo. Brasília, 2002.

Diretrizes Curriculares Nacionais para Licenciatura em Pedagogia. Brasília, 2006.

Diretrizes Curriculares Nacionais para Educação Básica. Brasília, 2012.

Programa Nacional das Escolas do Campo. Brasília, 2013.

. Lei de Diretrizes e Bases da Educação Nacional. Lei $n^{\circ}$ 9394/1996. Brasília, 1996.

Diretrizes complementares, normas e princípios para educação no campo. Brasília, 2008.

BRABO, T.S.A.M.; CORDEIRO, A.P.; MILANEZ, S.G.C. Formação do pedagogo e da pedagoga. Marília: Cultura Acadêmica, 2012.

CALDART, R.S. Dicionário da Educação do Campo. Rio de Janeiro. Editora: Expressão Popular, 2012.

CAMACHO, R.S. Paradigma em disputa na Educação do Campo. (Tese de Doutorado). Universidade Estadual Júlio Mesquita, 2014

CASAS, R.S.; LIMA,J.G. O pedagogo na educação do campo: considerações sobre a educação em Paranaguá. Paraná, 2012.

CHAVES, K.M.S.; FOSCHIERA, A.A. Prática de educação no campo no Brasil: escola família agrícola, casa família rural, e escola itinerante. Revista Pegada. v.15, n.02, p.1-19,2014.

FEIGES, M.M.F. Educação, pedagogos e pedagogia: questões conceituais, 2007.

FREIRE, P. Pedagogia da autonomia. 53.ed. Rio de Janeiro: Paz e Terra, 2017.

FRIGOTTO, G. Dicionário da Educação do Campo. Rio de Janeiro. Editora: Expressão Popular, 2012.

MACHADO, C. Educação do campo: a expressividade corporal na prática educativa. (Dissertação de Mestrado) Universidade do Tuiuti. Paraná, 2009.

MOLINA, C.M. Construção das licenciaturas em educação do campo para políticas de formação de educadores. Educação e Sociedade, Campinas. v.38 n.140, p. 587-609, 2017.

MOLINA, C.M.; SÁ, L.M. Verbete da escola do campo. 2.ed. Rio de Janeiro: Expressão Popular, 2014.

NERI, A.R.M. A função do pedagogo na escola pública: possibilidades de atuação na perspectiva do trabalho coletivo. Paraná, 2014.
NICKEL, M. Formação continuada de professores da educação do campo no município de Domingos Martins (Dissertação de Mestrado). UFES, 2016.

ROMANI, G.T.; BATISTA, C. Trabalho do professor pedagogo na escola pública, enquanto elemento articulador das relações políticas e pedagógicas. Paraná, 2014.

SANTOS, M. Educação do campo no plano nacional de educação: tensões entre a garantia e a negação do direito à educação. Rio de Janeiro. v.26, n.98, p.185-212, 2018.

SAVIANI, D. O papel do pedagogo como articulador do trabalho pedagógico na sociedade do capital. Palestra UENP, 2012

VIGHI, C.S.B. Da escola na zona urbana para escola do/no campo: os professores em foco. (Tese de Doutorado). Universidade Federal de Pelotas, 2013.

YIN, R. O estudo de caso. 2.ed. Rio Grande do Sul. Editora: Artmed, 2015.

\section{COPYRIGHT}

Direitos autorais: Os autores são os únicos responsáveis pelo material incluído no artigo.

Submetido em: 02/11/2018 Aprovado em: 11/12/2018 


\title{
Revista SODEBRAS - Volume 14 $\mathrm{N}^{\circ} 157$ - JANEIRO/ 2019
}

\section{A PARTICIPAÇÃO SOCIAL NA POLÍTICA DE ASSISTÊNCIA ESTUDANTIL DA UFOP, NA PERSPECTIVA DA GESTÃO SOCIAL}

\section{SOCIAL PARTICIPATION IN UFOP STUDENT ASSISTANCE POLICY IN THE PERSPECTIVE OF SOCIAL MANAGEMENT}

\author{
PRISCILA SENA GONÇALVES ${ }^{1}$; DRA ADILENE GONÇALVES QUARESMA ${ }^{1}$ \\ 1 - CENTRO UNIVERSITÁRIO UNA \\ priscilasenagoncalves@gmail.com; adilene.quaresma@prof.una.br
}

\begin{abstract}
Resumo - $O$ artigo discute a participação dos estudantes na Política de Assistência Estudantil e apresenta o produto técnico derivado da pesquisa que compreende a implantação de uma instância de participação social na Política de Assistência Estudantil - PAE da Universidade Federal de Ouro Preto UFOP, na perspectiva da gestão social. A pesquisa em questão foi sobre: "A Gestão da Política de Assistência Estudantil da UFOP: encontros $e$ desencontros dos sujeitos sociais envolvidos”, desenvolvida no Programa de Pós-graduação em Gestão Social do Centro Universitário Una. Com abordagem Qualiquantitativa, teve como dados a serem analisados 481 questionários de bolsistas, 8 entrevistas com técnicos $e 4$ entrevistas com gestores. Considera-que a ampliação da participação dos estudantes nos processos de decisão sobre a política de assistência estudantil traz contribuições significativas para a eficácia e eficiência da mesma.
\end{abstract}

Palavras-chave: Educação. Gestão Social; Política de Assistência Estudantil. Participação Social.

\begin{abstract}
The article discusses the participation of the scholarship holders in the Student Assistance Policy and presents the technical product derived from the research that includes the implementation of a social participation in the Student Assistance Policy - PAE of the Federal University of Ouro Preto UFOP, from the perspective management. The research in question was about "The Management of the Student Assistance Policy of UFOP: meetings and disagreements of the social subjects involved", developed in the Graduate Program in Social Management of University Center Una. With a Qualiquantitative approach, 481 scholarship questionnaires, 8 interviews with technicians and 4 interviews with managers were analyzed, and it is considered that the expansion of student participation in the decision-making processes on student assistance policy makes significant contributions to the effectiveness and efficiency of the same.
\end{abstract}

Keywords: Education. Social Management. Student Assistance Policy. Social Participation. Student Movement.

\section{INTRODUÇÃO}

A participação social ganhou destaque e força a partir da Constituição Federal de 1988 que estabelece o princípio democrático como primazia e inovou significativamente ao instituir espaços de participação e intervenção popular nas políticas sociais (BULLA e LEAL, 2006). A partir de então, a participação social vem se tornando um dos princípios organizativos nos processos de formulação de políticas públicas e de deliberação democrática (MILANI, 2008).

O Estado tem um importante papel no processo da participação social nas políticas públicas, não só como instituidor de canais de participação, mas principalmente, no incentivo e implementação de práticas participativas capazes de romper a dinâmica predominante, conscientizando e mobilizando a sociedade para uma participação mais efetiva na gestão das políticas públicas e a abertura da gestão pública à participação da sociedade civil (DIEGUES, 2012).

Ao analisar as instâncias de participação social instituídas nas políticas públicas, percebe-se que foram implantadas por um aparato ou uma obrigatoriedade legal e muitas das vezes motivadas pela condicionalidade para recebimento de recursos. Assim ocorre nos Conselhos de Saúde, Educação, Assistência Social, entre outros.

Na Política de Assistência Estudantil - PAE não há essa obrigatoriedade e ao pesquisar nos bancos de pesquisas, são raras discussões a respeito e poucas Universidades implementaram esta participação social de forma contínua.

$\mathrm{Na}$ pesquisa "A Gestão da Política de Assistência Estudantil da UFOP: encontros e desencontros dos sujeitos sociais envolvidos", da qual este artigo originou, obteve-se os seguintes resultados: $73,8 \%$ dos bolsistas apontaram a necessidade de ampliar ou criar mecanismos de participação na PAE; $19,5 \%$ sugerem o monitoramento da Política de Assistência Estudantil com a participação dos estudantes, inclusive na tomada de decisões. Os técnicos também falam sobre a dificuldade na relação Prace/Aluno, sendo que, $20,7 \%$ apontam como sugestão a participação efetiva dos estudantes, técnicos, professores e comunidade acadêmica em geral, na elaboração, execução e monitoramento da PAE.

Assim, constata-se que há mecanismo insuficiente de participação social na gestão da PAE da UFOP e compreende-se que as demandas e insatisfações apontadas pelos bolsistas e pelos técnicos, são resolvidas ou compreendidas com a implantação da instância de participação social, seja para entender os critérios, os limites da instituição e, também, para contribuírem com a construção da política, a partir das suas principais demandas.

E considerando a importância da profissão da pesquisadora, enquanto assistente social, que acumula, segundo Maia (2005, pág. 16) “competências e habilidades 
importantes no sentido de desvelar e atuar junto à realidade social e à população para a mediação da práxis da gestão social" e ainda "sobre os compromissos assumidos pelo serviço social nos referenciais ético-político, teóricometodológicos e técnico-operativos, que objetivam a afirmação dos valores da cidadania, democracia e justiça social, tanto quanto a gestão social" (MAIA, 2005, pág. 16), é que esta inquietou-se com a seguinte questão: Qual a importância da implantação da instância de participação social na gestão da Política de Assistência Estudantil da UFOP?

Os objetivos do artigo são: discutir a importância da implantação da instância de participação social na PAE da UFOP, na perspectiva da gestão social.

Este artigo está estruturado em torno de dois eixos centrais: o conceito de gestão social e a participação dos estudantes na gestão de políticas de assistência estudantil nas IFES e na UFOP e ao final, apresenta uma proposta de produto técnico da pesquisa, como exigência do Mestrado Profissional. A proposta consiste na implantação de uma instância de participação social na Política de Assistência Estudantil - PAE da Universidade Federal de Ouro Preto UFOP, na perspectiva da gestão social.

\section{METODOLOGIA}

A metodologia que orientou a pesquisa em questão foi qualitativa, mas com interatividade entre dados quantitativos e qualitativos, foi do tipo descritiva, teve como cenário a Universidade Federal de Ouro Preto e como sujeitos da pesquisa 481 estudantes/bolsistas, 8 técnicos e 4 gestores. Para a coleta de dados foi utilizado questionário on-line, via plataforma Google Formulário para os estudantes e entrevista semiestruturada com os técnicos e gestores.

Todos os entrevistados assinaram o Termo de Consentimento Livre e Esclarecido - TCLE e o termo de autorização após a aprovação da pesquisa pelos dois comitês de ética, da Universidade Federal de Ouro Preto (aprovado em 26/03/2018) e do Centro Universitário Una (aprovado em 20/08/2018)

Os dados da pesquisa foram coletados por meio de questionários e entrevistas estruturadas. Para isso, com relação a cada pergunta, foram analisadas as respectivas respostas correlacionando com a percepção dos bolsistas atendidos, técnicos e gestores sobre a gestão da política de assistência estudantil executada na Universidade Federal de Ouro Preto. Os dados obtidos foram analisados a partir da organização em categorias, geradas com base em referencial teórico previamente construído, com o objetivo de orientar e organizar as discussões e conclusões (OLIVEIRA, 2010). Os resultados quantitativos foram avaliados por estatísticas simples.

Para o desenvolvimento deste artigo foi realizado um estudo sobre gestão social e participação social, considerando os resultados da pesquisa "A Gestão da Política de Assistência Estudantil da UFOP: encontros e desencontros dos sujeitos sociais envolvidos" que aponta demanda dos bolsistas, técnicos e gestores por um maior envolvimento dos estudantes no planejamento e execução da PAE da UFOP.

Assim, indica-se como solução para a demanda apontada pelos sujeitos sociais envolvidos, a ampliação da participação social com a implantação da Comissão Permanente de Assistência Estudantil - COPAE, que terá por objetivos: elaborar, acompanhar e avaliar as atividades da PAE; atuar na aplicação e acompanhamento dos recursos orçamentários da PAE; implantar mecanismo de avaliação da PAE anual, envolvendo toda a comunidade acadêmica; promover a cada dois anos o Fórum da Política de Assistência Estudantil, como instrumento de participação da comunidade acadêmica na elaboração de programas e serviços e como instrumento de monitoramento da política e para eleição de novos membros da COPAE.

A COPAE será paritária, composta por 06 servidores da Prace, indicado pelo Pro-Reitor, 01 professor do curso de serviço social da UFOP, 01 servidor da área de planejamento da UFOP, 01 servidor da Pro Reitoria de Graduação e 9 bolsistas da PAE, e seus respectivos suplentes.

Para a designação dos bolsistas que farão parte da COPAE será realizado o I Fórum da Política de Assistência Estudantil da UFOP, cujo objetivo será difundir informações sobre esta política, com a apresentação realizada por profissional externo `a Universidade com domínio de conhecimento e atuação na área; apresentação das ações desenvolvidas pela Prace, nas suas diversas áreas; os limites institucionais; apresentação da COPAE e eleição dos membros estudantis.

O Fórum contará com momentos de formação sobre a política de assistência estudantil, momentos de grupos para elaboração de propostas, separados por áreas (moradia, bolsa, orientação estudantil, restaurante universitário, saúde) e conclusão dos trabalhos com a junção de todas as propostas em uma assembleia geral para deliberação e apreciação de todos.

Os bolsistas interessados em participar da COPAE deverão candidatar-se durante o evento, cada inscrição deverá constar um titular e seu respectivo suplente e a votação ocorrerá através de formulário on-line, na plataforma Minha UFOP, onde cada estudante poderá votar apenas uma vez em oito estudantes. Caso, o número de candidatos seja inferior ao número solicitado, ou seja, menos de 18 - nove titulares e nove suplentes será realizado campanha através da página da UFOP e envio de e-mails para os estudantes sobre a prorrogação do prazo para candidatura. A votação ocorrerá por um período de dez dias corridos, podendo ser prorrogado caso não atinja o número mínimo de votantes, que será $51 \%$ dos bolsistas ativos. Serão eleitos os 9 bolsistas com seus respectivos suplentes mais votados.

Sugere-se as seguintes ações para início das atividades da COPAE:

- Capacitação sobre a Política de Assistência Estudantil da UFOP (Histórico; Programas e Serviços Oferecidos; Normativas vigentes; Aplicação dos Recursos Orçamentários; Limites Institucionais);

- Discussão sobre a Resolução CUNI 1380 e Portaria Prace 13/2015;

- Realizar o monitoramento da Política de Assistência Estudantil a partir do resultado desta pesquisa de mestrado; - Planejamento das ações para a PAE.

\section{DISCUSSÃO TEÓRICA}

\section{1 - Gestão Social}

Gestão social é entendida como um processo dialógico onde a autoridade decisória é compartilhada entre os participantes da ação, em um espaço privilegiado de 
relações sociais onde todos têm o direito à fala, sem nenhum tipo de coação (TENORIO, 2008b).

A gestão social se efetiva, na relação sociedadeEstado, quando os governos institucionalizam formas de elaboração e implantação de políticas públicas que não se refiram ao cidadão como "alvo" de suas ações ou avaliador de resultados, mas sim como participante ativo no processo de elaboração dessas políticas, pois este processo deve ser contínuo e ocorrer desde a identificação do problema, o planejamento de sua solução e o acompanhamento da execução até a avaliação do impacto social efetivamente alcançado (TENORIO, 1998).

Desta forma a gestão social seria o caminho para a emancipação, pois incita a um "gerenciamento mais participativo, dialógico, no qual o processo decisório é exercido por meio de diferentes sujeitos sociais" (TENÓRIO, 2008a, p. 25-26).

O conceito de cidadania ou democracia deliberativa aproxima do que queremos elucidar sobre a participação dos estudantes na Política de Assistência Estudantil e esse conceito está relacionado em (TENORIO, 2008), pois contempla que a legitimidade das decisões deve ter origem a partir de processos de discussão mediados por princípios da inclusão, do pluralismo, da igualdade participativa, da autonomia e do bem comum.

Maia (2005a) aproxima e correlaciona distintos conceitos de gestão social discutidos em cinco textos, de seus respectivos autores Tenório (1998), Carvalho (1999), Singer (1999), Dowbor (1999) e Fischer (2002). Tenório (1998) define gestão social como democracia, cidadania, convívio e respeito às diferenças, que busca implementar processos sociais para ação gerencial em vista da democracia e cidadania. Carvalho (1999) discute gestão social como direitos de cidadania e equidade, que objetiva realizar ações sociais públicas para responder as demandas e necessidades da população. Singer (1999) aponta gestão social como vida, democracia e trabalho e tem como propósito desenvolver ações para o enfrentamento às necessidades da população a partir do trabalho e renda. Dowbor (1999) analisa gestão social como justiça, bemestar social, desenvolvimento humano e democracia, com vistas a transformar o desenvolvimento, atividade econômica como meio e bem-estar social fim do desenvolvimento. Finalizando com Fisher (2002) que aponta gestão social como ética da responsabilidade e democracia, gerindo processos de desenvolvimento social, com relações de poder, conflito e aprendizagem.

A partir da análise destes cinco referenciais teóricos Maia (2005a) conclui que gestão social é construção social e histórica, constitutiva da tensão entre os projetos societários de desenvolvimento em disputa no contexto atual, desenvolvimento do capital e desenvolvimento da cidadania. Essas duas referências de desenvolvimento apontam para distintas perspectivas de gestão social, que se constroem também neste movimento contraditório. Compreende gestão social como um conjunto de processos sociais com potencial viabilizador do desenvolvimento societário emancipatório e transformador, em vista ao enfrentamento às expressões da questão social, da garantia dos direitos humanos universais. Construção realizada em pactuação democrática com efetiva participação dos cidadãos historicamente excluídos dos processos de distribuição das riquezas e do poder.

A gestão contra o social apresenta-se como estratégia tecnológica e instrumental, viabilizadora da qualificação e eficiência do trabalho e organizações do campo social, afirmadores do capital e não da cidadania" (MAIA, 2005b, p. 2).

Assim, tomou-se a definição de gestão social elucidada por Maia (2005a), e as discussões de Tenório (1998; 2008) como base para as discussões acerca desta temática na pesquisa.

\section{2 - A importância da participação social nas políticas públicas}

As importantes inovações institucionais pós constituintes possibilitaram a criação de novas formas de governabilidade cujo objetivo é garantir a presença de múltiplos atores da sociedade na formulação, gestão, implementação ou no controle das políticas públicas (SILVA; BEGHIN; JACCOUD, 2005). Essas mudanças decorrem a partir dos princípios constitucionais que prescrevem a participação da sociedade na construção das políticas públicas, das regulamentações legais que condicionam o repasse de recursos federais a implantação dos Conselhos setoriais e do próprio processo de descentralização. Assim, diversas formas de participação foram se disseminando nos estados e municípios brasileiros (GOMES, 2003). Portanto, a institucionalização dos espaços de participação social não se dá apenas pelo fato de ser uma questão constitucional, mas também, como imposição legal para o recebimento dos recursos oriundos do governo federal.

Os espaços criados para a participação da sociedade no processo de tomada de decisão potencializam a eficiência das ações públicas, rompendo com os interesses corporativos da burocracia e as barganhas clientelistas, possibilitando o atendimento da real demanda da sociedade e a articulação de maneiras mais efetivas de acompanhamento e monitoramento das ações governamentais (ROCHA, 2011).

Os instrumentos de participação social são essenciais para a gestão social e podem contribuir ainda para o rompimento a tendência do poder público em servir exclusivamente aos interesses do capital (VILLELA; VIDAL; ARAUJO; COSTA; COSTA, 2016).

Assim, para o êxito da participação social é necessário a sua instrumentalização a partir de três importantes medidas. 1. Reforçar a participação, estimulando o protagonismo para que as reuniões não se constituem na forma consultiva, mas que as pessoas participem de todo o processo, desde a definição de prioridades, a aplicação e avaliação delas. 2. Buscar a participação do cidadão não organizado por meio da ampliação dos mecanismos de participação. 3. Impulsionar uma mudança em prol de uma cultura mais participativa no médio prazo, a partir de um diagnóstico mais preciso sobre as causas da omissão da participação cidadã (FONT, 2004, tradução nossa).

No caso da política de assistência estudantil há uma história construída a partir de mobilizações e reivindicações, tanto de trabalhadores da área, através do Fonaprace e Andifes, como por estudantes, através da UNE, entretanto, poucas universidades incentivam e priorizam as instâncias de participação social na gestão da política.

Nascimento e Arcoverde (2012) ressaltam a importância do envolvimento dos estudantes na construção da política de assistência estudantil, envolvendo-os no planejamento e avaliação dessa política, pois desta forma, as 
ações estariam comprometidas com os interesses do seu público.

Os estudantes não devem ser apenas vistos como público alvo da assistência estudantil, mas sim, sujeitos participativos que possam contribuir no seu planejamento e na elaboração dos programas e ações desta área, tornando-se propositores de novas alternativas e atuando de forma ativa e conjunta com as Pró-Reitorias (OLIVEIRA; VARGAS, 2012).

A UNE em seu III Seminário Nacional de Assistência Estudantil, ocorrido na Universidade Federal de Ouro Preto, em 2014, questiona a falta de uma maior participação e controle social, democracia e transparência na implementação da assistência estudantil, reivindicando a criação de instrumentos que possibilitem aos discentes participarem paritariamente da elaboração e das decisões acerca desta área em suas Instituições de ensino.

\section{3 - Participação dos estudantes na gestão de políticas de assistência estudantil da UFOP}

Um fator preponderante para o êxito de qualquer Programa/projeto/atividade/ação é a efetiva participação de todos os atores envolvidos nesta Política. A Prace estabelece diálogos com o aluno, através de atividades direcionadas e na maior parte das vezes pela área de orientação estudantil. Há ainda contato direto através da área de moradia e com menos frequência com a área de bolsas.

Os contatos Prace e Aluno por meio da área de orientação estudantil acontecem com a execução do projeto Bem-Vindo Calouro, momento no qual é apresentado os serviços e atividades da Pro-Reitoria de Assuntos Estudantis e Comunitários - Prace e os discentes são convidados a participarem de uma pesquisa sobre o perfil do ingressante. Através do workshop de diagnóstico que convoca o estudante bolsista que perdeu coeficiente para um acompanhamento, levando-o a refletir sobre seus objetivos, ações e prioridades e realiza um diagnóstico sobre fatores que estão dificultando a sua permanência na Universidade. Através dos workshops temáticos, oferecidos a todos os estudantes da Universidade, com temas relacionados às demandas apresentadas pelos estudantes no workshop de diagnóstico, abordam Estratégias de Estudo no Ensino Superior, Gestão e organização do tempo, Planejamento Financeiro, Estratégias de apresentação em público e Ansiedade. Além destes workshops há ainda acompanhamento individual e em grupo para alunos com dificuldades na gestão do tempo (Foco nas Metas) e dificuldades de falar em público (Ponto de Encontro).

Com a área de moradia há reuniões, encontros e intervenções visando ao acompanhamento dos estudantes que estão residindo nas moradias estudantis da Universidade, buscando oferecer um ambiente propício para os estudos. Além disso, a área de moradia conta com uma instância de participação que é o Comitê Permanente de Moradia Estudantil - COPEME, regulamentado pela Resolução CUNI n ${ }^{\circ}$ 1.687, de 11 de dezembro de 2014, que tem por finalidade assessoramento administrativo, visando ao aperfeiçoamento das ações institucionais referente a política de moradia estudantil. São assembleias mensais, com participação de representantes de diversos setores envolvidos na gestão das moradias da Universidade e representantes dos alunos das diversas modalidades de moradia estudantil.
O contato com a área de bolsas acontece na maior parte das vezes em entrevistas convocadas pelas assistentes sociais para verificação de alguma informação imprecisa na documentação. Devido o número de alunos da Universidade e o número reduzido de profissionais estes atendimentos são, na maior parte das vezes, de acordo com as demandas dos profissionais. As demandas dos alunos são atendidas através de orientações por e-mail e através da triagem com bolsistas treinadas para informações quanto à documentação para avaliação socioeconômica e outras dúvidas sobre o processo para obtenção das bolsas. Não há assembleias diretas com estudantes sobre esta área.

Assim, percebemos que a participação dos estudantes na gestão da política de assistência estudantil da Universidade Federal de Ouro Preto é mínima. Há participação regulamentada dos estudantes no Comitê Permanente de Moradias Estudantis - COPEME. Outras participações dos estudantes ocorrem no decorrer das atividades desenvolvidas pela área de orientação estudantil (Workshop de diagnóstico, Bem-vindo Calouro, Workshop temático) e nos atendimentos individuais.

Há participação dos estudantes no Conselho Universitário - CUNI, que é o órgão superior de deliberação nas áreas administrativas e disciplinar, e também, no Conselho de Ensino, Pesquisa e Extensão - CEPE, que delibera sobre questões relacionadas ao ensino, pesquisa e extensão. Estas duas instâncias deliberativas tratam de todos os assuntos pertinentes a Universidade, inclusive sobre a Política de Assistência Estudantil.

A UFOP conta com várias entidades estudantis como forma de organização dos estudantes para assuntos administrativos e acadêmicos da universidade, e sobre as vivências estudantis em geral. São elas o Diretório Central dos Estudantes - DCE; os Centros e diretórios Acadêmicos de cada curso; a Aliança Bíblica Universitária - ABU; Grupo de Oração Universitária - GOU, a Associação das Repúblicas Federais de Ouro Preto - REFOP.

Mas, analisando o conceito de gestão social elucidado por (TENORIO, 1998) e Maia (2005), percebe-se que a gestão da política de assistência estudantil da UFOP pode aprimorar ainda mais a efetividade de suas atividades e ações, fomentando a participação ativa dos estudantes no processo de elaboração desta política, fazendo assim uma gestão social desta política.

\section{CONSIDERAÇÕES FINAIS}

Ao longo do estudo do qual este artigo origina-se foi possível identificar que a participação social é fundamental para o êxito de qualquer política pública e no caso da Assistência Estudantil tem-se uma positividade que os usuários possuem capacidade de participar ativamente e com poucas limitações, já que se trata de estudantes universitários.

Desta forma, a implantação da Comissão Permanente de Assistência Estudantil - COPAE atenderá a lacuna encontrada na pesquisa da ausência de mecanismos de participação social. Além disso, a política de assistência estudantil da Universidade Federal de Ouro Preto será construída a partir das demandas dos próprios estudantes, eles enquanto sujeitos ativos e participantes do processo, e contará, também, com a atuação de servidores da área, com conhecimentos práticos, técnicos e professor com conhecimento específico requerido e servidor de outro setor com conhecimento geral sobre a universidade, o que 
contribui diretamente para a execução cotidiana dos serviços da Prace. Portanto, considera-se que isso trará ganhos para a política e racionalidade na destinação dos recursos, visto que os estudantes poderão participar do processo de decisão sobre as prioridades para o atendimento de suas próprias demandas.

\section{REFERÊNCIAS}

BULLA, L. C.; LEAL, M. L. M. A participação da sociedade civil no Conselho Municipal de Assistência Social: o desafio de uma representação democrática. Textos \& Contextos. Porto Alegre, v. 3, n. 1, 2006.

DIEGUES, Geraldo César. A Construção da Participação Social na Gestão das Políticas Públicas: O Protagonismo do Governo Local no Brasil. Administração Pública e Gestão Social, [S.1.], v. 4, n. 4, p. 365-380, dez. 2012. ISSN 2175-5787. Disponível em: <https://www.apgs.ufv.br/index.php/apgs/article/view/115/1 99>. Acesso em: 11 set. 2018.

FONT, J. Participación ciudadana y decisiones públicas: conceptos, experiências y metodologias. In: ZICCARDIA, A. (Coord.). Participación ciudadana y políticas sociales del ámbito local. México, DF: 2004. 23-42 p.

GOMES, E. G. M. MAIA, M. Práxis da Gestão Social nas Organizações Sociais: uma mediação para a cidadania. Tese (Doutorado em Serviço Social) - Pontifícia Universidade Católica do Rio Grande do Sul, Porto Alegre, 2005a.

Gestão Social - Reconhecendo e construindo referenciais. Revista Virtual Textos \& Contextos, n ${ }^{\circ} 4$, $2005 b$.

MILANI, C. R. S. O princípio da participação social na gestão de políticas públicas locais: uma análise de experiências latino-americanas e europeias. Revista de Administração Pública, v. 42, n. 3, p. 551 - 579, jun. 2008.

NASCIMENTO, C. M.; ARCOVERDE, A. C. B. O serviço social na assistência estudantil: reflexões acerca da dimensão político-pedagógica da profissão. In: Fórum Nacional de Pró-Reitores de Assuntos Comunitários e Estudantis - Fonaprace. Revista Comemorativa 25 anos: histórias, memórias e múltiplos olhares. Uberlândia: UFUPROEX, 2012. p. 167-79.

OLIVEIRA, S. B.; VARGAS, M. W. A assistência estudantil como espaço privilegiado de educação para os direitos. In: Fórum Nacional de Pró-Reitores de Assuntos Comunitários e 85

Estudantis - Fonaprace. Revista Comemorativa 25 anos: histórias, memórias e múltiplos olhares. Uberlândia: UFUPROEX, 2012.

ROCHA, C. V. Gestão pública municipal e participação democrática no Brasil. Revista de Sociologia e Política, v. 19, n. 38, p. $171-185$, fev. 2011.

SILVA, F. B. DA; BEGHIN, N.; JACCOUD, L. Políticas sociais no Brasil - Participação social, conselhos e parcerias. In: JACCOUD, L. (Ed.). Questão social e políticas sociais no Brasil contemporâneo. Brasília: IPEA, 2005. v. 8p. 435.

TENÓRIO, F.G. Gestão Social: uma perspectiva conceitual. Biblioteca Digital da Fundação Getúlio
Vargas. Rio de Janeiro, 1998. Disponível em: http://bibliotecadigital.fgv.br/ojs/index.php/rap/article/view File/7754/6346. Acesso em 02 de fevereiro de 2017.

Um espectro ronda o terceiro setor, o espectro do mercado. 3 Ed. Ijuí: Editora da Unijuí, 2008a.

A trajetória do programa de estudos em gestão social (PEGS). In SILVA JR, J. T.; MÂISH, R. T.; CANÇADO, A. C.; SCHOMMER, P. C. Gestão Social: Práticas em debate, teorias em construção. Fortaleza: Imprensa Universitária, 2008b.

UFOP. Aprova nova redação do Regimento Interno do Comitê Permanente de Moradia (Copeme) e revoga-se a Resolução CUNI n. 852. Disponível em http://www.soc.ufop.br/files/RESOLUCAO_CUNI_1687.pd f. Ouro Preto, 2014. Acesso em 04 de out. 2016.

VILLELA, L. E; VIDAL, M. O.; ARAUJO, A. C; COSTA, N. L. S. F.; COSTA, E. G. A conferência nacional das cidades como instrumento de políticas públicas para o desenvolvimento territorial: a percepção dos conselheiros nos processos participativos e deliberativos. Cad. EBAPE.BR, v. 14, Edição Especial, Artigo 11, Rio de Janeiro, Jul. 2016.

\section{COPYRIGHT}

Direitos autorais: Os autores são os únicos responsáveis pelo material incluído no artigo.

Submetido em: $23 / 11 / 2018$

Aprovado em: 10/12/2018 


\author{
Revista SODEBRAS - Volume 14 \\ $\mathrm{N}^{\circ} 157$ - JANEIRO/ 2019
}

\title{
ASPECTOS RELACIONADOS À ALIMENTAÇÃO DE EDUCANDOS DA EJA DENTRO E FORA DA ESCOLA EMEF "PROF. PEDRO SIMÃO”, EM ALEGRE, ESPÍRITO SANTO
}

\author{
FOOD NEED FOR EJA STUDENTS RELATED TO FOOD INSIDE AND \\ OUTSIDE EMEF SCHOOL "PROF. PEDRO SIMÃO", IN ALEGRE, \\ ESPÍRITO SANTO
}

\begin{abstract}
MANUELA BARCELOS MARTINS ${ }^{1}$; GERALDO MOREIRA ALVES ${ }^{1}$, WANESSA SOARES LUIZ SILVA ${ }^{1}$, RUTHENEIA ALVES SANTANA; MARCUS ANTONIUS DA COSTA NUNES ${ }^{2}$; DANIEL RODRIGUES SILVA ${ }^{2}$ 1 - ESTUDANTE DE MESTRADO EM CIÊNCIA, TECNOLOGIA E EDUCAÇÃO DA FACULDADE VALE DO CRICARÉ, SÃO MATEUS, ES; 2 - PROFESSOR DA FACULDADE VALE DO CRICARÉ, SÃO MATEUS, ES danfarma@bol.com.br
\end{abstract}

\begin{abstract}
Resumo - O objetivo deste estudo foi determinar os horários de alimentação de educandos da EJA antes, durante e após as aulas e relaciona-los às necessidades alimentares dos educandos. $A$ linha metodológica deste estudo foi orientada pela abordagem qualitativa, embasada na pesquisa bibliográfica e na pesquisa de campo. Como resultado constatou-se a importância da merenda escolar e que necessita ser analisada como uma refeição que aponta para a manutenção do adolescente ou do adulto da EJA alimentados, enquanto permanecem na escola, involuntariamente de suas condições socioeconômicas, pois, não é um instrumento para o desarraigamento da desnutrição. Concluiu-se que os diferentes aspectos relacionados à alimentação escolar em muito contribuem para que ocorra um melhor processo de ensino aprendizagem.
\end{abstract}

Palavras-chave: Educação de Jovens e Adultos. Alimentação Escolar. Processo de Ensino e Aprendizagem.

Abstract - The objective of this study was to determine the feeding times of EJA students before, during and after classes and relate them to the food needs of the students. The methodological line of this study was guided by the qualitative approach, based on bibliographic research and field research. As a result, the importance of school meals was verified and needs to be analyzed as a meal that aims to maintain the adolescent or adult of the EJA fed while they remain in school involuntarily from their socioeconomic conditions, since it is not an instrument for the uprooting of malnutrition. It was concluded that the different aspects related to school feeding contribute greatly to a better learning process.

Keywords: Youth and Adult Education. School Feeding. Process of Teaching and Learning.

\section{INTRODUÇÃO}

Historicamente, a Alimentação Escolar mundialmente e no Brasil está vinculada a expansão da rede pública de ensino para os segmentos da classe trabalhadora mais pobre, o que significa que, de acordo com a história a Alimentação Escolar proporcionada, dependendo das regiões do Brasil recebeu a denominação de "lanche", ou mesmo, "merenda" no qual teve um caráter compensatório e assistencialista.
Comumente ouve se falar que "o aluno só vem para escola para comer", ou que, "é a comida que atrai o aluno para escola". Afirmativas como estas têm muito de verdade devido à pobreza, miséria e fome que alcança milhões de brasileiros, cabendo, pois, a pedagogia progressista não uma simples constatação do caráter assistencialista, nem mesmo à recusa da Alimentação Escolar, sob o pretexto de que "a escola não é uma entidade assistencial". Compete, pois, à pedagogia progressista realizar um trabalho prático e significativo com a realidade objetiva.

O Programa Nacional de Alimentação Escolar (PNAE) como política social pública, atende de modo suplementar, a toda rede de educação básica no Brasil. O PNAE parte da compreensão de que se articula com o emergente direito alimentar e com os princípios que gerem a educação brasileira, notadamente o de igualdade de condições de acesso e permanência na escola e pela oferta de padrões de qualidade na educação.

Ainda por todo o mundo, há pessoas que não tem acesso a alimentos em quantidade ou qualidade indispensável para a manutenção da saúde. A desnutrição e a fome juntas são riscos para saúde mundial, uma vez que mata mais pessoas anualmente do que a AIDS, a malária e a tuberculose juntas (SAGLIOYATZIMIRSKY, 2006). Neste sentido, sabe-se que a fome é a situação em que o indivíduo não se alimenta o suficiente para suprimento dos gastos energéticos com as atividades básicas diárias. E a desnutrição é o fato do pouco ou nenhum consumo de alimentos saudáveis, fonte de minerais, vitaminas e energias imprescindíveis para que o corpo e o cérebro se desenvolvam.

Pesquisas mostram que cada vez mais os brasileiros estão mais obesos, e que outra parcela da população está desnutrida. A importância de hábitos de alimentação saudáveis na manutenção da saúde e da qualidade de vida pode ser alcançada se não houver carência de nutrientes, o que deixa o organismo suscetível a doenças e dificuldades mental. Porém, é um disparate falar que a população está engordando e ficando desnutrida 
concomitantemente, pois há um desacordo entre a quantidade e a qualidade do que se come.

Conforme a Organização das Nações Unidas para a Alimentação e a Agricultura, do inglês Food and Agriculture Organization (FAO), uma agência das Nações Unidas que conduz esforços internacionais para eliminar a fome, cerca de 925 milhões de pessoas no mundo não comem de forma adequada para serem consideradas saudáveis (FAO, 2012). No Brasil, a convivência com doenças diretamente coligadas à fome, e à desnutrição, como ainda, doenças desenvolvidas por hábitos alimentares impróprios, que comprometem não apenas a classe dos menos favorecidos, mas igualmente outros segmentos da população que não estão isentos às deformidades impostas pelas alterações do modelo de desenvolvimento econômico dominante.

Tem-se como objetivo deste estudo apresentar a importância da alimentação escolar dos educandos da Educação de Jovens e Adultos (EJA), da rede municipal de Alegre, ES, contribuindo assim para a sua aprendizagem diante das dificuldades sociais e econômicas.

A problemática no que diz respeito à importância da alimentação nutricional escolar dos educandos da Educação de Jovens e Adultos, pois se sabe que na maioria das vezes esses jovens e adultos não tem uma alimentação adequada em sua residência, uma vez que a clientela em sua maioria sai diretamente do seu trabalho profissional para a escola, e neste pensar a escola é o único local de oferta. Assim levanta-se a seguinte questão: Qual a contribuição da alimentação escolar no desenvolvimento e aprendizagem dos educandos da Escola "Professor Pedro Simão", no município de Alegre, ES?

Na concepção de Freire (2005, p. 98), “ensinar exige compreender que a educação é uma forma de intervenção no mundo" e, nesse contexto, entende-se que se aprende e se (re) constrói nas relações que é estabelecida com os semelhantes ao longo da vida. Isto posto, é na prática da merenda escolar nas escolas que se carregam significados, e se marcam as diferenças, cujo diferencial existente é o de que nas escolas públicas brasileiras o fornecimento de forma gratuita da merenda, em muito auxilia no processo de ensino e aprendizagem dos alunos.

A Constituição Brasileira, em seu art. 208, incisos IV e VII, assegura que a alimentação escolar é uma obrigação do governo federal, estadual, distrital e municipal (BRASIL, 1988). Portanto, devem-se garantir a efetivação do direito à alimentação para todos os alunos matriculados na rede pública. Esta não é uma alimentação qualquer, mas uma que seja de qualidade, cujos nutrientes sejam indispensáveis para que os alunos se sintam bem alimentados e que isso o leve a melhor compreender todo o conhecimento apresentado em sala de aula.

A política de alimentação e nutrição no Brasil teve início na década de 1930 , com a realização do primeiro inquérito sobre alimentação, orçamento familiar e condições de vida da população.

Dentre todos os benefícios do Programa, prevê-se também a contribuição para a mudança no hábito alimentar dos seus beneficiários e de suas famílias, no qual se tem por finalidade o atendimento a $15 \%$ das necessidades nutricionais diárias. Por conseguinte, a alimentação na escola pode representar acesso a alimentos que a família do estudante não pode ofertar por apresentar renda insuficiente para sua aquisição; e podem ser complementados em termos nutritivos os lanches trazidos de casa, que são em sua maioria, inadequados quantitativamente e qualitativamente, representando assim, grande importância em termos alimentares para os educandos. Deste modo, além da suplementação alimentar, a alimentação serve para o desenvolvimento de atividades educacionais (CASTRO, 1957).

Em julho de 1994, ocorreu a descentralização da merenda escolar pela Lei Federal n. 8.913 de 12/07/1994, o qual em seu artigo $4^{\circ}$ determina que a elaboração dos cardápios dos programas de alimentação escolar, sob a responsabilidade dos estados e municípios, através de nutricionista, sendo ainda desenvolvida em concordância com o Conselho de Alimentação Escolar (CAE), bem como, considerando as prioridades alimentares locais com incentivo na formação dos hábitos alimentares sadios, valorizando os espaços educativos (BRASIL, 2006a).

O CAE, em uma de suas diretrizes visa:

“[...] o apoio ao desenvolvimento sustentável, com incentivos para aquisição de gêneros alimentícios diversificados, preferencialmente produzidos e comercializados em âmbito local (BRASIL, 2006b)."

E define ainda, a composição dos CAE, primeiramente constituído por representantes da administração pública local, responsável pela área da educação; dos professores; dos pais de alunos; e de trabalhadores rurais, que teria que elaborar o seu regimento interno e cuja função fundamental seria fiscalizar e controlar a aplicação dos recursos do PNAE, formalizando denúncias no caso de irregularidades, conforme seu Artigo $2^{\circ}$ (BRASIL, 2006b).

Conforme as normas do PNAE, esse programa possui com objetivo "atender às necessidades nutricionais dos alunos e à formação de hábitos alimentares saudáveis durante a permanência em sala de aula, contribuindo para o seu crescimento, desenvolvimento, aprendizagem e rendimento escolar" (BRASIL, 2009, p. 38).

Pela Lei n.11.947/09, em seu art. $4^{\circ}$ :

“[...] O Programa Nacional de Alimentação Escolar - PNAE tem por objetivo contribuir para o crescimento e o desenvolvimento biopsicossocial, a aprendizagem, o rendimento escolar e a formação de hábitos alimentares saudáveis dos alunos, por meio de ações de educação alimentar e nutricional e da oferta de refeições que cubram as suas necessidades nutricionais durante o período letivo (BRASIL, 2009)."

Por regulamentação, a Resolução/CD/FNDE n³8/2009 estabelece valores de referência para energia, macro e micronutrientes para alimentação oferecida aos alunos matriculados em creche, pré-escola, ensino fundamental, ensino médio e ensino de jovens e adultos, com valores variáveis, dependendo do número de refeições oferecidas e o período de aula (BRASIL, 2009b). 
No Programa, a questão da merenda escolar, tem importância tal sobre a alimentação que pode utilizar o espaço educativo em que está inserido, no sentido de promover o diálogo com a comunidade escolar sobre os fatores que influenciam suas práticas alimentares diárias, possibilitando questioná-la e modificá-las, mediante temas aliados no currículo das escolas. Criando igualmente, um ambiente estimulador e adequado ao desenvolvimento de práticas alimentares que induzam a uma vida mais saudável.

Daí o PNAE ter destaque por seu caráter histórico e por sua abrangência, sendo avaliado como um dos maiores programas de alimentação escolar do mundo uma vez que seu tempo de atuação, sua continuidade e compromisso constitucional desde 1988, seu caráter universal, o número de atendimento por aluno e o volume de investimentos já alcançados.

De um modo geral, os alunos EJA são tratados como uma massa de estudantes, sem identidade, qualificados sob diferentes nomes, relacionados diretamente ao chamado "fracasso escolar".

A EJA restitui-se mais que um direito, uma vez que é a chave para a inserção no mercado de trabalho atual; portanto é consequência da prática da cidadania como condição para uma plena participação na sociedade. Enfatiza-se que a Educação de Jovens e Adultos (EJA) está prevista na Lei n. 9424/96 (BRASIL, 1996) sendo considerada como parte integrante da Educação Básica, e que precisa ser encarada com a mesma obrigação presente no Ensino Fundamental. Contudo, levantamentos evidenciam as discordâncias na aplicação deste segmento escolar.

Um discurso entre educadores, políticos, e a sociedade em geral ultimamente, volta-se para a luta por uma educação de qualidade, e para um trabalho em prol disso. É imprescindível perceber como as políticas governamentais intervêm neste meio. Com esse propósito, compete-lhes discutir quais as contribuições necessárias da alimentação escolar, para um bom desenvolvimento das crianças, e no caso dos alunos da EJA, para uma educação de qualidade, sendo, portanto, necessário compreender a importância da alimentação escolar para o desenvolvimento da aprendizagem dentro da sala de aula.

A questão da alimentação escolar é de fundamental importância no processo de ensino e aprendizagem dos educandos. Quem se alimenta manifesta melhor disposição e melhoramento no humor, para o desenvolvimento em suas habilidades e atividades. Nesta acepção a alimentação torna-se significativa na contribuição do desenvolvimento do indivíduo, tanto na escola como na sociedade.

Um dos fatores principais para a eutrofia, ou seja, a nutrição de boa qualidade e para o bom desenvolvimento físico, psíquico e social das pessoas é uma alimentação equilibrada e balanceada. Esta se refere a um padrão alimentar correspondente às necessidades biológicas e sociais dos indivíduos e conforme as etapas da vida, devendo estar embasada em práticas alimentares culturalmente referenciadas; valorizando o consumo de alimentos saudáveis regionais (como legumes, frutas e verduras); observando ainda, a qualidade e a quantidade dos alimentos nas refeições; e por fim considerando os aspectos comportamentais e afetivos pautados nessas práticas. Caso uma alimentação que não cumpra com essas condições pode ocasionar aumento de peso e/ou em deficiências de vitaminas e minerais (BRASIL, 2007).

Em termos de valor calórico e princípios nutritivos quanto à adequação da refeição, utilizam-se as recomendações propostas na Resolução/CD/FNDE $n^{\circ} 38 / 2009$, que estabelece como valor de referência para o atendimento de $20 \%$ das necessidades nutricionais para alunos de ensino fundamental, nas faixas etárias de 16 a 18 anos e para os alunos do ensino de jovens e adultos, nas faixas etárias de 19 a 30 anos e 31 a 60 anos (BRASIL, 2009b). Para tal, calcula-se a média dos valores de referência conforme as faixas etárias, e considera-se como adequadas as refeições que apresentarem, em média, $462 \mathrm{kcal}, 75,1 \mathrm{~g}$ de carboidratos, 14,4 g de proteínas e 11,6 g de lipídios (BRASIL, 2009b).

Para Valente (2002, p.104) o rendimento escolar está associado à falta de alimentação adequada na escola, pois,

“[...] uma alimentação adequada é aquela que colabora para a construção de seres humanos saudáveis, consciente de seus direitos e deveres, enquanto cidadão do Brasil e do mundo".

Assim sendo, a alimentação saudável é essencial para a saúde, pois sem se alimentar o educando pode não conseguir aprender o que o professor está ensinando na sala de aula.

Como instrumento de política pública de alimentação e nutrição, a alimentação escolar no Brasil, teve origem a partir de uma maior necessidade do Estado de buscar soluções para o problema da fome, ainda que de modo suplementar e setorial. Conforme Ana Castro (1984), já na primeira metade do século XX, a fome era um problema endêmico, e não epidêmico, pois se referia à pobreza extrema e às práticas alimentares e serviços públicos impróprios. Prontamente, sua natureza era política e econômica. Deste modo, dessa percepção, o combate à fome transcorreu como objeto de políticas governamentais, sendo elaborados vários planos e programas tendo em vista a implantação de uma política nacional de alimentação e nutrição que amenizasse, pelo menos em parte, os problemas na área social e de saúde pública.

Para Health People (2000 apud CAVALCANTI, 2009, p.17),

“[...] a alimentação desempenha papel decisivo para crescimento e desenvolvimento físico da criança em idade escolar, época que passa por processo de maturação biológica, juntamente com o desenvolvimento sociopsicomotor".

Ressalta Freitas (2002, p.15) que,

"[...] a alimentação influi em nossa disposição, em nosso estado emocional e até em nossa inteligência. Esse contexto chega a prejudicar o interesse dos educandos em frequentar a escola com isso apresenta irritabilidade, estresse, baixo rendimento, apatia entre outros".

Assim, para que se tenha uma boa aprendizagem é necessário que o aluno esteja bem alimentado com todos os nutrientes prováveis, de modo que seu organismo tenha como funcionar em todos os sentidos. 
Valente afiança categoricamente que:

“[...] o fracasso escolar seria o resultado de sequelas irreversíveis produzidas no sistema nervoso central de crianças submetidas à desnutrição nos dois primeiros anos de vida. Outros, no outro extremo, afirmam que o fracasso escolar é, em grande parte, reflexo da inadequação da escola pública. Outros ainda buscam no contexto social de vida das crianças a principal determinação (VALENTE, 2002, p.2930).”

Desta forma, todo aluno bem alimentado, com todos os nutrientes que o corpo necessita, tem uma aprendizagem mais evolvida. Ainda Valente (2002, p.32) reafirma que,

"um adulto ou criança com 'fome do dia' fica desligado do mundo, não consegue prestar atenção ao que está fazendo e muito menos no que a outra pessoa possa estar fazendo, como, por exemplo, uma professora em sala de aula".

Conclui Valente (2002, p.32) que há

“[...] importância da alimentação e da nutrição adequadas durante toda a vida, para que crianças, jovens e adultos possam desenvolver plenamente suas capacidades físicas, psíquicas e intelectuais".

Consequentemente, uma boa alimentação certamente faz parte de um rendimento escolar mais elevado, considerando que seus nutrientes desenvolvem as suas capacidades de forma que todos os órgãos dos alunos possam funcionar e especialmente o seu lado intelectual, formando pensamentos, expressando suas ideias, conquistando seus espaços e deste modo, a escola estará operando como um local que busca conhecimentos e a alimentação como uma contribuição de uma educação de qualidade. $\mathrm{O}$ objetivo do presente estudo é avaliar os aspectos relacionados à alimentação de educandos da EJA dentro e fora da escola EMEF "prof. Pedro Simão", em Alegre, Espírito Santo

\section{METODOLOGIA}

A linha metodológica determinada para encaminhar este estudo foi orientada pela abordagem qualitativa, embasada na pesquisa bibliográfica e na pesquisa de campo. Dessa forma, foram utilizados livros, revistas e artigos e periódicos científicos especializados em Educação e Nutrição e ainda, em legislações específicas sobre o tema; bem como, na pesquisa em bibliotecas virtuais como Scielo e Google Acadêmico, dentre outros, adotados como referência e que impõem o embasamento científico, buscando-se fundamentação teórica que servirá, especialmente, como aporte para encontrar respostas à indagação sobre a importância de alimentação escolar e sua contribuição no processo de ensino e aprendizagem.

A pesquisa foi realizada na Escola Municipal de Ensino Fundamental "Professor Pedro Simão", no município de Alegre, ES. O objeto de estudo foram os alunos do $1^{\circ}$ a $8^{\circ}$ ano do turno noturno da EJA. Os entrevistados responderam o questionário com questões objetivas que versa sobre as questões a serem investigadas. Os dados coletados durante o desenvolvimento da pesquisa de campo foram sistematizados e analisados para a construção de dados estatísticos, sob a forma de tabelas e gráficos.

O procedimento adotado foi de pleno acordo com o órgão responsável pela Alimentação Escolar, bem como, pela escola.

\section{RESULTADOS E DISCUSSÃO}

Para a pesquisa foram entrevistados 109 alunos, com faixa etária entre 15 a 80 anos, sendo 42 mulheres e 66 homens de $1^{\circ}$ a $8^{\circ}$ ano do turno da noite (noturno) da EJA. Os alunos iniciaram as aulas a partir de $19 \mathrm{~h} 30 \mathrm{~min}$ e finalizaram às 23 horas todas as noites da semana.

Na questão 1, sobre qual horário se arrumavam para ir à escola, responderam os alunos em sua maioria que das $17 \mathrm{~h} 30 \mathrm{~min}$ às $18 \mathrm{~h}$ e das $18 \mathrm{~h} 30 \mathrm{~min}$ às $19 \mathrm{~h}$, com um percentual concomitante de $65,5 \%$, e uma minoria das $16 \mathrm{~h} 30 \mathrm{~min}$ às $17 \mathrm{~h}(7,6 \%)$. Isto considerando o tipo de clientela (dona de casa, domésticas, trabalhadores do comércio e de mecânica e ainda, de zona rural (Tabela 1).

Ao questionar os entrevistados em relação ao horário de alimentação realizada antes de ir para escola, a maioria sendo $34,6 \%$ alimenta das $17 \mathrm{~h} 30 \mathrm{~min}$ às $18 \mathrm{~h} 30 \mathrm{~min}$ demais resultados conforme Tabela 1 .

$\mathrm{Na}$ questão 3, indagados sobre em geral que horas sente fome na escola, os entrevistados responderam que das $18 \mathrm{~h} 30 \mathrm{~min}$ às $19 \mathrm{~h} 30 \mathrm{~min} \quad(34,6 \%)$, das $20 \mathrm{~h}$ às $20 \mathrm{~h} 30 \mathrm{~min}(38,4 \%)$ e que não sente $(27 \%)$ (Tabela 1$)$.

Tabela 1 - Porcentagem de alunos de EJA relacionada aos horários que se arrumam para ir à escola, se alimentam antes de ir à escola e sentem fome na escola

\begin{tabular}{|c|c|c|c|}
\hline \multirow[b]{2}{*}{ Horários } & \multicolumn{3}{|c|}{ Questionamentos } \\
\hline & $\begin{array}{c}\text { A que } \\
\text { horas se } \\
\text { arruma } \\
\text { para ir à } \\
\text { escola }(*)\end{array}$ & $\begin{array}{c}\text { A que horas } \\
\text { se alimenta } \\
\text { antes de ir à } \\
\text { escola }(* *)\end{array}$ & $\begin{array}{c}\text { A que } \\
\text { horas } \\
\text { sente } \\
\text { fome na } \\
\text { escola } \\
(* * *)\end{array}$ \\
\hline $16: 30$ às $17: 00 \mathrm{~h}$ & $7,6 \%$ & --- & --- \\
\hline $17: 30$ às $18: 00 h$ & $65,5 \%$ & --- & --- \\
\hline $18: 30$ às $19: 00 \mathrm{~h}$ & $65,5 \%$ & --- & -- \\
\hline $12: 00$ às $15: 00 \mathrm{~h}$ & --- & $26,9 \%$ & -- \\
\hline $16: 00$ às $17: 00 \mathrm{~h}$ & --- & $26,9 \%$ & --- \\
\hline $17: 30$ às $18: 30 h$ & --- & $34,6 \%$ & --- \\
\hline Não realiza & --- & $11,6 \%$ & --- \\
\hline $18: 30$ às $19: 30 \mathrm{~h}$ & -- & --- & $34,6 \%$ \\
\hline $20: 00$ às $20: 30 h$ & --- & --- & $38,4 \%$ \\
\hline Não sente & --- & --- & $27 \%$ \\
\hline
\end{tabular}

Legenda: (*) Dados referentes a questão 1; (**) Dados referentes a questão 2 ; (***) Dados referentes a questão 3. Fonte: Próprios autores.

Observa-se que para todos os questionamentos prevalece um grande intervalo sem que os alunos tenham realizado uma alimentação adequada e satisfatória conforme se aconselha para uma alimentação saudável, ou seja, a de se alimentar de 3 em 3 horas.

No que se refere à questão 4 (faz alguma refeição antes de ir para a escola?), $50 \%$ dos alunos responderam que sim; $30,7 \%$ às vezes e $9,3 \%$, que não fazem nenhuma refeição antes de ir para a escola. Perguntados na questão 5 , sobre se merendam na escola, $76,93 \%$ disseram que 
sim; 3,84\% afirmaram que não merendam na escola e $19,23 \%$, às vezes (Figura 1).

Figura 1 - Comparativo de refeições realizadas antes do horário escolar, do número de alunos que merendam, ou que levam algum tipo de merenda e que sentem dificuldade de raciocínio antes do recreio na EMEF "Professor Pedro Simão", em Alegre, ES, 2017

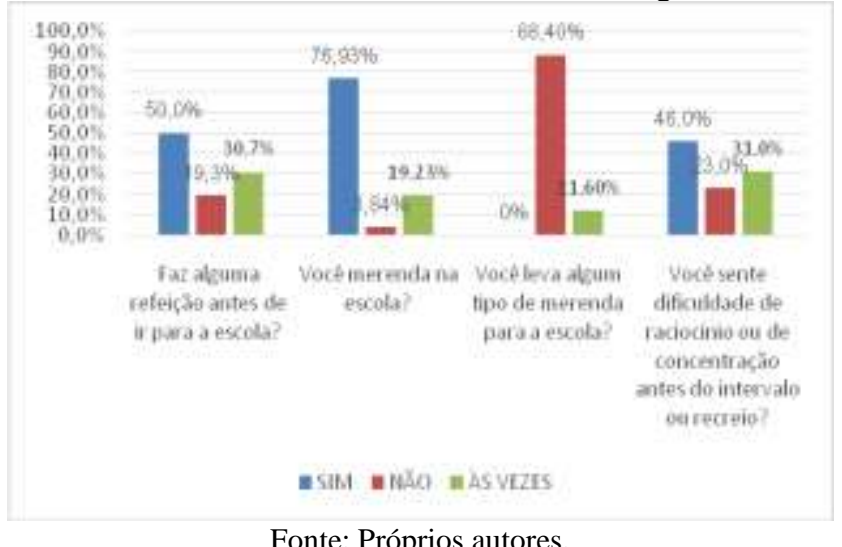

Fonte: Próprios autores.

$\mathrm{Na}$ questão 6, sobre levar algum tipo de merenda para a escola, ninguém leva merenda para a escola; $88,40 \%$ não levam nenhum tipo de merenda e às vezes $11,6 \%$ (Figura 1).

Os alunos ainda responderam à questão 7 , sobre sentir dificuldade de raciocínio ou de concentração antes do período do intervalo ou recreio. Foram categóricos em dizer que $\operatorname{sim}(46 \%)$, em não $(23,09 \%)$ e às vezes $(31 \%)$ (Figura 1).

Diante dos resultados obtidos observa-se que a maioria dos alunos faz uma refeição antes de ir para a escola, contudo os horários são muito diversificados e em um espaço de tempo muito prolongado, o que acarreta sentir muita fome antes do horário do recreio e consequentemente dificultando o processo de atenção, concentração e retenção do conhecimento. Neste sentido, cabe uma revisão por parte dos gestores, tanto da escola quanto do Programa de Alimentação Escolar municipal, no que se refere a servir as refeições (merenda escolar) no início das aulas e um desjejum posteriormente ou o inverso.

Verdadeiramente, garante Abreu (2001), se não há qualquer comprobação da desnutrição no desenvolvimento cognitivo, é sabido que a fome tem interferência na aprendizagem. Enquanto a desnutrição grave gera lesões no sistema nervoso, a fome é, contrariamente, uma situação transitória, ou virtualmente transitória, que não provoca lesões irreversíveis, mas que inibe a realização de qualquer atividade do ser humano. É fome do dia.

Por fim, para a questão 8, sobre o número de vezes por semana que os alunos merendam na escola, $18 \%$ responderam de 1 a 2 vezes, $24 \%$ entre 3 a 4 vezes e $58 \%$ para 4 a 5 vezes por semana, ou seja, a grande maioria dos alunos merendam na escola todas as noites, valendo, portanto, pelo jantar (Figura 2).
Figura 2 - Quantitativo de vezes semanais que os alunos merendam na EMEF "Professor Pedro Simão", em Alegre, ES, 2017

Quaritas vezes por semana vocé merenda na escola

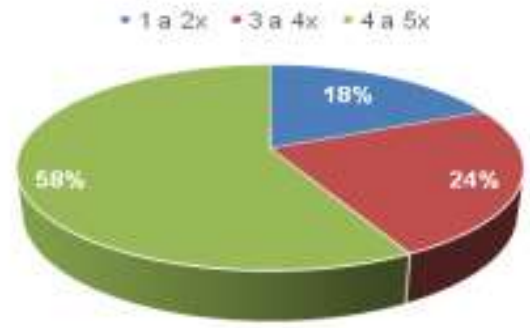

Fonte: Próprios autores.

Corroborando com os resultados apresentados acima, sabe-se que uma boa alimentação certamente faz parte de um rendimento escolar mais elevado, uma vez que seus nutrientes alargam as suas capacidades para que todos os órgãos dos alunos funcionem bem e especialmente o seu lado intelectual, formando pensamentos e expressando melhor suas ideias (RIBEIRO; PEREIRA, 2015).

Como a aprendizagem é importante na vida do ser humano, assim é a sua alimentação. A alimentação escolar vem refletir no melhor rendimento, uma vez que durante sua estada na escola, se bem alimentado estará preparado para o enfrentamento dos desafios da aprendizagem. Os alimentos são refletidos na saúde, fornecem maior resistência às doenças, cooperam para uma maior resistência, aperfeiçoando a aparência e dando capacidade para uma melhor aprendizagem e disposição para estudar. Neste contexto, ambas caminham juntas, contudo, a alimentação escolar não pode ser considerada como um dos fundamentos para uma educação de qualidade (RIBEIRO; PEREIRA, 2015).

A partir das constatações apresentadas, pode-se concluir conforme Abreu (2001) que é necessário discutir a merenda escolar. Inicialmente, é forçoso desvinculá-la dos falsos e inatingíveis objetivos de compor-se em solução para a desnutrição e o fracasso escolar. A merenda escolar necessita ser analisada como uma refeição que aponta para a manutenção do adolescente ou do adulto da EJA alimentados, enquanto permanecem na escola, involuntariamente de suas condições socioeconômicas, pois, não é um instrumento para o desarraigamento da desnutrição.

\section{CONCLUSÃO}

Com base nos resultados obtidos, conclui-se que os diferentes aspectos relacionados à alimentação escolar abordados neste estudo em muito contribuem para que ocorra um melhor processo de ensino aprendizagem. Estes foram positivamente referenciados para que a alimentação escolar adequada venha contribuir para um melhor processo de ensino e aprendizagem.

Percebeu-se, ainda, que, os alimentos são refletidos na saúde, fornecendo uma resistência maior às doenças, contribuindo para melhoria da capacidade para aprender e disposição para estudar. Ficou constatado que os alunos da EJA necessitam do atendimento do Programa de Alimentação Escolar devido às suas características peculiares, são homens, mulheres, jovens, adultos ou idosos trabalhadores que buscam a escola, e que não tiveram 
oportunidade de estudos na época própria e pertencem todos a uma mesma classe social.

\section{REFERÊNCIAS}

ABREU, M. Alimentação escolar: combate à desnutrição e ao fracasso escolar ou direito da criança e ato pedagógico? Rev. Nutr. vol.14, n.3. Sept./Dec. Campinas: 2001. Disponível em:

$<$ http://www.scielo.br/scielo.php?script=sci_arttext\&pid=S1 415-52732001000300009\&lng=in\&nrm=iso\&tlng=in>. Acesso em: 15 dez. 2007.

BRASIL. Constituição da República Federativa do Brasil de 1988. Diário oficial da República Federativa do Brasil. Brasília-DF: Imprensa Oficial da União. 1988.

BRASIL. Fundo Nacional de Desenvolvimento da Educação - FNDE. Programa Nacional de Alimentação Escolar. Brasília: FNDE, 2006a.

BRASIL. Fundo Nacional de Desenvolvimento da Educação - FNDE. Resolução FNDE/ CD n⿳ 32, de 10 de agosto de 2006. Estabelece as normas para a execução do Programa Nacional de Alimentação Escolar. Brasília: Diário Oficial da União, 2006b. Disponível em:< https://www.fnde.gov.br/fnde/legislacao/resolucoes/ item/3106-resolu\%C3\%A7\%C3\%A3o-cd-fnde-n\%C2\%BA32>. Acesso em: 02 dez. 2017.

BRASIL. Ministério da Saúde. Secretaria de Atenção Básica. Glossário temático: alimentação e nutrição. Brasília: Ed. do Ministério da Saúde, 2007.

BRASIL. Lei $\mathbf{n}^{\circ}$ 11.947, de 16 de junho de 2009. Dispõe sobre o atendimento da alimentação escolar e do Programa Dinheiro Direto na Escola aos alunos da educação básica. Brasília: Diário Oficial da União, 2009a.

BRASIL. Ministério da Educação. Resolução FNDE/CD/No 38 de 16 de julho de 2009. Brasília: Fundo Nacional de Desenvolvimento da Educação, 2009 b.

CASTRO, Josué de. Geografia da fome. $5^{\text {a }}$ ed. São Paulo, Ed. Brasiliense, 1957.

CASTRO, Ana Maria. (org.) Fome: Tema Proibido. Rio de Janeiro/RJ: Vozes, 1984.

CAVALCANTI, Leonardo de Almeida. Efeitos de uma intervenção em escolares do ensino fundamental I, para a promoção de hábitos alimentares saudáveis. Tese de Mestrado, 2009, Brasília. Disponível em: < https://www.bdtd.ucb.br:8443/jspui/bitstream/123456789/11 04/1/Texto $\% 20$ completo $\% 20$ Leonardo $\% 20$ Cavalcanti $\% 202$ 009.pdf >. Acesso em: 20 dez. 2017.

FAO. Diretrizes voluntárias em apoio à realização progressiva do direito à alimentação adequada no contexto da segurança alimentar nacional. Roma, 2004. Trad. Ministério das Relações Exteriores do Brasil. Brasília, DF, 2012.

FREIRE, Paulo. Pedagogia do Oprimido. $40^{\mathrm{a}}$ ed. Rio de Janeiro: Paz e Terra, 2005.

FREITAS, Paulo G. Saúde um Estilo de Vida. Baseado no Equilíbrio de Quatro Pilares. São Paulo: IBRASA, 2002.

RIBEIRO, Ana Cristina de Lima Andrade; PEREIRA, Denilson Diniz. Alimentação Escolar e sua contribuição para uma Educação de Qualidade. Campina Grande, Vol. 1. 4. ed. ISSN 2316-1086. Realize editora, 2015. Disponível em: $<$ http://www.editorarealize.com.br/revistas/fiped/trabalh os/TRABALHO EV050_MD1_SA6_ID726_22102015212 642.pdf>. Acesso em: 15 dez. 2017.

SAGLIO-YATZIMIRSKY, Marie-Caroline. A comida dos favelados. Em: Estudos Avançados. 2006.

VALENTE, Flávio Luiz Schieck. Direito humano à alimentação: desafios e conquistas. São Paulo: Cortez, 2002.

\section{COPYRIGHT}

Direitos autorais: Os autores são os únicos responsáveis pelo material incluído no artigo.

Submetido em:23/10/2018 Aprovado em: 07/12/2018 


\author{
Revista SODEBRAS - Volume 14 \\ $\mathrm{N}^{\circ} 157$ - JANEIRO/ 2019
}

\title{
O TRABALHO DO ENFERMEIRO JUNTO ÀS MULHERES NA COLETA DO EXAME CITOPATOLÓGICO NA UNIDADE DE SAÚDE III - SÃO JOSÉ DO CALÇADO-ES
}

\author{
THE NURSE WORK TOWARD WOMEN IN THE COLLECTION OF THE \\ CYTOPATHOLOGICAL EXAMINATION IN HEALTH UNIT III - SÃO JOSÉ DO \\ CALCADO-ES
}

\author{
SARA CASTILHOLI TIRADENTES RAMALHO ${ }^{1}$; RUTHENEIA ALVES SANTANA ${ }^{1,2}$;GERALDO \\ MOREIRA ALVES ${ }^{1,2}$; JULIANNA GODOI DE SOUZA ${ }^{1}$; JUSCELIO ABREU CLEMENTE ${ }^{2}$; ROBERTO \\ SANTOS BARBIERI ${ }^{1}$; MARCUS ANTONIUS DA COSTA NUNES ${ }^{1}$; LUANA FRIGULHA GUISSO ${ }^{1}$; \\ WANESSA SOARES LUIZ SILVA ${ }^{1,2}$; BRUNO AUGUSTO DE REZENDE ${ }^{1}$; DANIEL RODRIGUES SILVA ${ }^{1,2^{*}}$ \\ 1- MESTRANDA FACULDADE VALE DO CRICARÉ; 2- CENTRO UNIVERSITÁRIO DE CARATINGA \\ marcaonunes@hotmail.com; saracastilholi@hotmail.com \\ autor correspondente: danfarma@bol.com.br**
}

\begin{abstract}
Resumo - Entre as neoplasias femininas no Brasil, o câncer do colo de útero recebe grande empenho em um trabalho de educação de saúde pelo profissional de enfermagem em um processo de prevenção e promoção de saúde, com assistência integralizada e humanizada. Objetivou verificar a percepção de um grupo de mulheres atendidas em Unidade de Saúde, em relação à coleta de Exames Citopatológicos de colo uterino, feita pelo enfermeiro, no que se refere durante o atendimento à satisfação, confiança e esclarecimento de dúvidas. $O$ estudo foi de revisão de literatura com pesquisa de campo, sob a forma de coleta de dados, na US-III, de São José do Calçado/ES, entre 2015 a 2017. Concluiu-se que, com essa forma de atendimento, podem-se buscar soluções adequadas através de uma postura crítico-reflexiva para uma assistência mais humanizada.
\end{abstract}

Palavras-chave: Câncer de Colo do Útero. Profissional de Enfermagem. Prevenção. Atendimento. Acolhida.

Abstract - Among the female neoplasms in Brazil, cervical cancer receives a great deal of work in health education by the nursing professional in a process of prevention and health promotion, with integrated and humanized care. The objective was to verify the perception of a group of women attended at the Health Unit, regarding the collection of cervical cytopathological examinations, made by the nurse, in what refers to satisfaction, confidence and clarification of doubts. The study was a review of literature with field research, in the form of data collection, in US-III, of São José do Calçado / ES, between 2015 to 2017. It was concluded that, with this form of - seeking appropriate solutions through a critical-reflexive posture for more humanized assistance.

Keywords: Cervical Cancer. Nursing Professional. Prevention. Care. Welcomed.

\section{INTRODUÇÃO}

Os casos de câncer de colo de útero são duas vezes maior nos países subdesenvolvidos, quando se compara aos países desenvolvidos. Na população feminina, esse tipo de câncer é o mais comum, exceto aos tumores de pele não- melanoma, ficando atrás somente do câncer de mama. (BRASIL, 2010)

No Brasil, o câncer de colo de útero é a quarta causa de morte de mulheres por câncer, o que se estima um risco de 17 casos a cada 100 mil mulheres (BRASIL, 2011a). De acordo com dados do Instituto Nacional de Câncer José Alencar Gomes da Silva (INCA, 2015), no Estado do Espírito Santo existe uma estimativa de 340 novos casos, sendo destes 40, somente para a capital do estado, Vitória (BRASIL, 2011a). Entre 2012 e 2013 foram estimados em torno de 18 mil casos no país (BRASIL, 2011b). O Estado do Espírito Santo, no ano de 2016, estimou $16,05 \%$ para 100 mulheres (INCA 2015).

$\mathrm{Na}$ atuação do enfermeiro, deve-se conscientizar sobre os fatores de risco, diagnóstico e tratamento precoce da $\mathrm{Ca}$ de colo de útero, como também, valorizar ao acolhimento à paciente na consulta ginecológica, reconhecendo que há dificuldades na realização da consulta ginecológica.

Nascimento (2010) enfatiza que a equipe da saúde deve desenvolver atividades de educação em saúde objetivando prestar esclarecimentos sobre as formas de prevenção do câncer uterino, com a finalidade de conscientizar as usuárias na adoção de atitudes de cuidado com a saúde no seu dia a dia.

O estudo levanta dados do grupo de mulheres atendidas em uma Unidade de Saúde, em relação à coleta de Exames Citopatológicos de colo uterino, feita pelo Profissional de Enfermagem no período de 2015 a junho de 2017, bem como, apresentar o papel desempenhado pelos mesmos neste tipo de coleta de rastreamento.

Fundamentando-se principalmente nas leituras de Bergman et al. (2013), Soares et al. (2011), Brasil (2011) INCA (2015) dentre outros, o estudo busca a partir do quantitativo de exames realizados providenciar os encaminhamentos necessários face aos resultados em uma Unidade de Saúde, em relação à coleta de Exames Citopatológicos de colo uterino, realizada pelo Enfermeiro. 
Contudo, é importante apresentar um breve relato sobre o câncer do colo do útero.

O câncer do colo do útero, também identificado como câncer cérvico-uterino, representa aproximadamente $15 \%$ dos tipos de câncer que agridem as mulheres, é considerado o segundo tipo de câncer mais comum, chegando a atingir o $1^{\circ}$ lugar em alguns países em desenvolvimento e o $6^{\circ}$ lugar em países desenvolvidos. (SOARES et al.,2011)

Quando não adequadamente tratada, a infecção pelo Papiloma vírus humano (HPV) tem sido assinalada como um grave fator de risco para o desenvolvimento da patologia que é ainda coligada a diversos cofatores, como exposição ao agente infeccioso da Chlamydiatrachomatis e da imunodeficiência adquirida, tabagismo, uso de contraceptivos orais por longo tempo e a multiparidade (INCA 2010).

De acordo com a Agência Internacional para Pesquisa em Câncer (IARC), o impacto global do câncer alcançou mais que o dobro nos últimos 30 anos. Estimou-se que, em 2008, ocorreriam cerca de 12 milhões de novos casos e 7 milhões de óbitos (INCA,2010).

Segundo o Ministério da Saúde para este tipo de câncer a prevenção está ligada à realização de exame preventivo ginecológico, também conhecido como Papanicolau. Este exame, se realizado precocemente e corretamente, diminui em até $70 \%$ a mortalidade pelo câncer. (BRASIL, 2010)

Para um programa nacional de combate ao Câncer de Colo de Útero (CCU) é imprescindível ter quatro elementos extraordinários em sua realização: detecção precoce, prevenção primária, diagnóstico/tratamento e cuidados paliativos. Na redução do CCU, a modalidade mais eficaz é a detecção precoce, pois na concepção de Vasconcelos et al. (2011) a prevenção pode ser conseguida por meio das atividades de rastreamento, dentre elas o exame citopatológico e a educação em saúde.

Em geral, no momento em que ocorre a identificação de fatores de risco é feita a prevenção primária da doença. Já a prevenção secundária do CCU é efetuada através do exame citopatológico para a detecção da doença. O exame tem sido usado nos rastreamentos do $\mathrm{CCU}$, proporcionando uma detecção precoce para ser tratado e curado (NARCHI; FERNANDES, 2013).

Segundo o Ministério da Saúde (BRASIL, 2013) a estratégia de rastreamento indicada no Brasil é o exame citopatológico, dando preferência às usuárias de 25 a 64 anos. Portanto, é necessário garantir a integralidade, organização e a qualidade dos programas de rastreamento, assim como, o seguimento das usuárias ao programa. Ressaltando que, todas as etapas, desde os procedimentos, da coleta até os resultados e encaminhamentos, são de suprema importância para ter benefícios obtidos do exame de prevenção do CCU (MELO et al., 2009).

A infecção cervical pelo HPV em sua maioria é temporária e regride espontaneamente, entre um período de seis meses a dois anos, posteriormente à exposição (BERGMAN et al., 2013). No baixo número de ocorrências nos quais a infecção continua e, de maneira especial, é ocasionada por um tipo viral oncogênico, no qual pode ocorrer o desenvolvimento de lesões precursoras, que a identificação e tratamento adequado permitem a prevenção do carcinoma cervical invasivo (BERGMAN et al., 2013).

Além de aspectos relacionados à própria infecção pelo HPV, ou seja, o tipo e a carga viral, a infecção única ou múltipla, outros fatores vinculados à imunidade, à genética e ao comportamento sexual podem influenciar os mecanismos, ainda duvidosos, que originam a regressão ou a persistência da infecção e também a progressão para lesões prenunciadoras ou câncer. Ressalva-se ainda que, também a idade intervém nesse processo, sendo que a maior parte das infecções por HPV em mulheres com menos de 30 anos apresenta uma regressão natural, já em mulheres acima dessa idade a persistência é mais recorrente (BERGMAN et al., 2013). Também, o tabagismo amplia o risco para o desenvolvimento do câncer do colo do útero, na proporção do número de cigarros fumados por dia e ao início em idade precoce. A área de promoção à saúde realiza ações para o controle do câncer de colo de útero, prevenção da doença e qualidade de vida (BERGMAN et al., 2013).

Deste modo, o Profissional de Enfermagem ao intervir nessas ações faz atividades, como as visitas domiciliares e o enfermeiro na consulta de enfermagem de forma humanizada e integralizada, esclarece cada procedimento ao longo do exame Papanicolau. Assim, contribuem para um melhor atendimento à população feminina, encaminhando adequadamente as usuárias que apresentam alterações citológicas, e ainda, divulgam informações à população sobre os fatores de risco, as ações de prevenção e a detecção precoce do câncer. Para Silva et al. (2008) promover essas ações é diminuir os fatores de risco, diagnosticar e tratar precocemente a doença.

Estas ações envolvem todos os níveis de atenção à saúde, no entanto, é na Atenção Básica que se torna possível um maior alcance, por haver um maior contato dos profissionais da saúde com a comunidade. Dentro deste âmbito, a Estratégia de Saúde da Família (ESF) é um Programa do Sistema de Saúde Brasileiro, com objetivo de buscar a reorientação do modelo assistencial, o que inclui em sua prática uma maior articulação entre a prevenção e a promoção da saúde, mediante a expansão e a qualificação da atenção primária, o que gera então, um ambiente favorável à reorganização do modo de rastreamento do câncer de colo do útero (VALE et al., 2010; INCA, 2010).

Parada et al. (2008) explicam que o Profissional de Enfermagem tem um importante papel dentro das equipes de ESF e o seu comportamento por todo o atendimento pode ser determinante na assistência prestada. Esses profissionais estão envolvidos em todas as ações que se relacionam com o câncer de colo do útero, e, é por meio de ações educativas com a participação da comunidade, que o conhecimento sobre essa neoplasia, é transmitido, todas as dúvidas sobre o exame são esclarecidas e a comunidade percebe o quanto é significativo esta prevenção.

Diante do exposto, o objetivo desta pesquisa é identificar o conhecimento e o modo de como usuárias se comportam a respeito da prevenção do câncer de colo do útero e sua relação com os procedimentos a serem utilizados, tendo como ênfase o papel da enfermagem em um trabalho preventivo. Levanta-se então a seguinte problemática: Diante do quantitativo de coleta de exames de rastreamento citopatológico do colo, como o profissional de enfermagem contribui para o atendimento às pacientes?

\section{PROCEDIMENTOS}

Estudo de cunho exploratório, descritivo e qualitativo, em todo o seu desenvolvimento a base foi a revisão bibliográfica e a coleta de dados, no qual foram analisados os constantes da base de informações do SISCAN/Ministério da Saúde, relacionado ao número de usuárias da população alvo 
que realizaram exames de rastreamento Citopatológico do Colo, da Unidade de Saúde III, do município de São José do Calçado, no período de janeiro de 2015 a junho de 2017.

No estudo forma incluídos artigos e dissertações que abordavam o assunto. Foram ainda, incluídos no estudo, toda população alvo prevista no sistema SISCAN, a qual corresponde às usuárias entre 25 e 64 anos. No entanto, a coleta do exame Citopatológico é feita a partir de 13 anos, isto quando a jovem já possui vida sexual ativa. Assim, os exames de rastreamento Citopatológico do Colo, da Unidade de Saúde III, do município de São José do Calçado, no período de janeiro de 2015 a junho de 2017 foram analisados após coleta de dados no Sistema SISCAN.

Após dados coletados no Sistema SISCAN, foi elaborado um questionário de modo a coletar a opinião das usuárias quanto ao atendimento na coleta de material, não apenas dentro da faixa etária determinada pelo SISCAN, mas por toda a clientela que é atendida na Unidade de Saúde III. O questionário foi aplicado pela equipe de enfermagem, em um total de 100, sendo entregue às usuárias da Unidade de Saúde, quando de consulta e ou exame ginecológico.

Após coleta e tabulação dos dados realizou-se a elaboração de tabelas e gráficos para uma melhor análise e discussão dos resultados.

O estudo não foi submetido Comitê de Ética, e nem os participantes assinaram termo de consentimento livre e esclarecido., devido os dados terem sido retirados do Sistema SISCAN.

\section{RESULTADOS}

Após análise dos dados coletados sobre os exames de rastreamento Citopatológico do Colo, da Unidade de Saúde III, do município de São José do Calçado, no período de janeiro de 2015 a junho de 2017 no Sistema SISCAN, são estes apresentados na Tabela 1.

Tabela 1 - Percentual de Rastreamento de exame citopatológico da

\begin{tabular}{|c|c|c|c|c|}
\hline \multirow[b]{2}{*}{$\begin{array}{l}\text { Período } \\
\text { (Ano) }\end{array}$} & \multicolumn{3}{|c|}{ faixa etária alvo e outras } & \multirow[b]{2}{*}{$\%$} \\
\hline & $\begin{array}{l}\text { Faixa Etária } \\
(25 \text { a } 64 \text { anos) }\end{array}$ & $\%$ & $\begin{array}{l}\text { Outras } \\
\text { faixas } \\
\text { etárias }\end{array}$ & \\
\hline 2015 & 272 & 77,28 & 80 & 22,72 \\
\hline 2016 & 349 & 70,05 & 97 & 21,95 \\
\hline 2017 & 32 & 78,25 & 09 & 21,75 \\
\hline
\end{tabular}

Vale ressaltar que o SISCAN é um sistema na versão plataforma web, que integra os Sistemas de Informação do Câncer do Colo do Útero (SISCOLO) e do Câncer de Mama (SISMAMA) implantada em 30/10/2012. Este sistema tem por objetivo, enquanto ferramenta de gestão, fortalecer as ações de controle e prevenção destes cânceres, gerando dados que subsidiam seu monitoramento e avaliação.

Por meio dos relatórios, o gestor pode conhecer a distribuição dos exames de colo do útero e de mama para organizar o acesso a rede de serviços, contribuindo para a estruturação das redes de assistência à saúde e otimizando a utilização dos recursos, e verificar a distribuição dos resultados dos exames, indicando auditorias e capacitações locais, quando necessário, qualificando os dados do sistema de informação. Por fim, avaliar a qualidade dos exames por meio da análise comparativa do resultado de rastreamento e de seu resultado histopatológico, e então construir indicadores para acompanhar o desempenho do programa de controle destes cânceres e fazer análises temporal e espacial.

Importante acrescentar que, o Exame Citopatológico do Colo em sua maioria é coletado pelo Profissional de Enfermagem, ficando uma parcela menor para o médico clínico da Unidade de Saúde, uma vez que este tem por competência a realização da consulta e os encaminhamentos necessários.

Percebe-se que nesta Unidade de Saúde ocorreu uma boa demanda de exame citopatológico, tanto no que se refere à faixa etária alvo do programa, quanto nas outras faixas etárias, com ressalva para o ano de 2017, que conforme esclarecimento dado não foi possível realizar a coleta devido à falta de material na unidade. Neste sentido, pode-se atentar para a discrepância da proposta do Programa no que se refere aos seus objetivos, é oferecido, no entanto ocorre descontinuidade por falta de material.

O Programa de Atenção Integral à Saúde da Mulher (PAISM), do Ministério da Saúde, sugere amparo integral a todo e qualquer contato que a mulher tiver com os serviços de saúde, e que seja usado em prol da promoção, proteção e recuperação da sua saúde. As direções desse programa, por conseguinte, foram estabelecidas dentro da visão de uma atenção elementar, conforme o conceito de integralidade da assistência, envolvendo todas as etapas da vida, da adolescência até a velhice, respeitando-se, até mesmo, a individualidade de cada uma dessas etapas (BRASIL, 2006).

Na figura 1, é possível observar pelo rastreamento de exame citopatológico da faixa etária alvo informado pela Unidade de Saúde III, que o percentual dentre os três anos consecutivos esteve em uma média de $78 \%$ de cobertura nesta faixa etária, mesmo tendo ocorrido uma descontinuidade de programa, o que vem apresentar uma diferença dos dados retirados no Sistema SISCAN.

Figura 1 - Rastreamento de exame citopatológico da faixa etária alvo

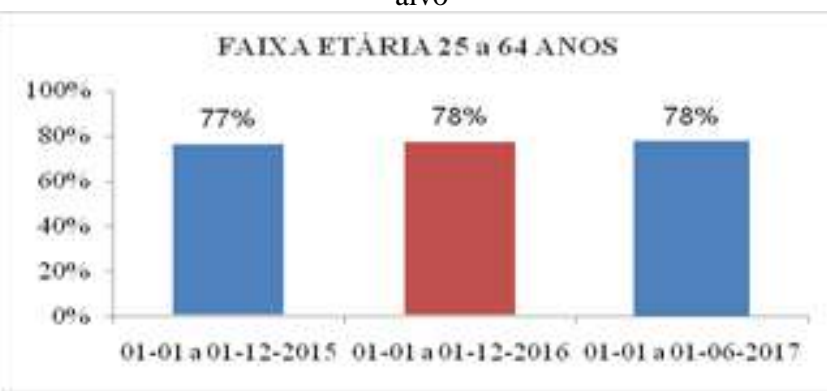

Fonte: SISCAN.

Isto considerado sabe-se que, o exame ginecológico tem seu valor epidemiológico na prevenção do câncer, com metodologia necessária também em programas de planejamento familiar, atendimento a patologias obstétricas, pré-natal, e controle de doenças sexualmente transmissíveis. Assim, a consulta ginecológica de enfermagem tende não apenas a prestar um atendimento volvido para os aspectos biológicos das usuárias, porém sobretudo inter-relacioná-los com os aspectos sociais e psicológicos, afiançando, deste modo, que a assistência prestada seja interdisciplinar, inovadora, transformadora e integral. Torna-se então, premente nesta totalidade, respeitar cada usuária perante suas singularidades, especificidades e ciclos de vida, afiançando que suas demandas biológicas, sociais e psicológicas sejam atendidas e resolvidas, respeitando continuamente a 
autonomia das usuárias frente ao seu processo de saúde e doença. (TEIXEIRA et al., 2013)

Com base no questionário apresentado às usuárias que passaram por rastreamento de exame citopatológico na Unidade de Saúde III, do município de São José do CalçadoES, foram levantadas as mais variadas faixas etárias.

O maior índice de coleta de exames ocorreu entre 46 a 56 anos $(72 \%)$, seguidos de $14 \%$ respectivamente para as faixas etárias de 13 a 34 anos. Para as demais faixas etárias apresentadas na legenda não houve nenhuma resposta. Esses dados chamam a atenção, uma vez que no SISCAN, a população alvo é de 25 a 65 anos, e constatou-se que há boa demanda entre as faixas mais jovens, devido a uma nova mentalidade das mulheres que estão iniciando sua atividade sexual mais cedo, especialmente no que diz respeito às préadolescentes. (Figura 2)

Figura 2 - Rastreamento de exame citopatológico da faixa etária na US-III- Município de São José do Calçado- ES

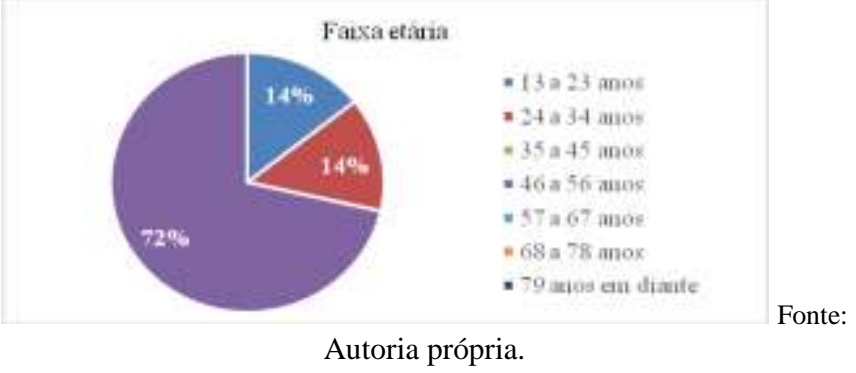

Catafesta et al. (2015) ressalta que apesar da importância do exame ginecológico, muitas mulheres não parecem considerá-lo como um procedimento habitual e isento. Normalmente, existe vergonha, reações de medo, repulsa à própria genitália e constantes adiamentos na procura do serviço de saúde. As mulheres destacam sensações de desconforto, vulnerabilidade e ansiedade quando fazem o exame ginecológico.

O profissional enfermeiro, na performance de suas ocupações em Ginecologia, não precisa valorizar os aspectos teórico-científicos, em detrimento dos aspectos psicoafetivos, na relação enfermeiro e usuária.

Assim sendo, para dirigir uma consulta inteira e perfeita, deve-se respeitar a usuária como cidadã, não podendo deixar de avaliar sobre os pontos sociais e psicossomáticos, aqueles responsáveis pela baixa de resistência e pelo aparecimento de novas patologias. $\mathrm{O}$ enfermeiro deve observar os aspectos que envolvem o dia a dia da usuária, percebendo a avaliação dos problemas relativos ao trabalho, à afetividade e à sexualidade, pesquisando, deste modo, a integralidade da assistência.

Ocorre que estudos psicossomáticos vêm confirmar que algumas queixas são vestígios de dificuldades de relacionamentos conjugais, por ocasião da falta de informação, preconceitos, ansiedade, violência sofrida, temores, imaturidade de um ou de ambos os cônjuges, provocando frigidez, vaginismo, dispareunias, impotência, ejaculação precoce ou tardia do parceiro. Isso confirma que a maior parte das mulheres só busca o atendimento clínicoginecológico para a resolução de algum problema. (BRITO; CAMARGO,2011)

Corroborando com o estudo, observou-se que a Sistematização da Assistência em Enfermagem é pouco usada na sua integralidade.
Acrescenta Catafesta et al. (2005) que a consulta de enfermagem não é apresentada como uma ferramenta indispensável para auxílio na orientação, no registro e na coordenação do atendimento de enfermagem, também não se observa apreensão com a promoção de orientações durante a consulta. Assim, é de fundamental importância que o enfermeiro esteja capacitado e possua os conhecimentos necessários para a realização do Processo de Enfermagem.

$\mathrm{Na}$ Tabela 2, pode-se observar, que as usuárias indagadas sobre a última vez de coleta de exame citopatológico de colo uterino, a maioria (43\%) não se lembra de quando ocorreu a coleta, $14 \%$ a realizou em 2015 , outras $14 \%$ no ano de 2016 e $29 \%$ no ano de 2017 , até o mês de junho, quando da interrupção do programa. Destas, 100\% não fez tratamento radioterápico, $86 \%$ não fez tratamento hormonal durante a menopausa e $14 \%$ não sabe.

Tabela 2 - Quantitativo Percentual de exames citopatológicos de colo uterino e tratamento realizados

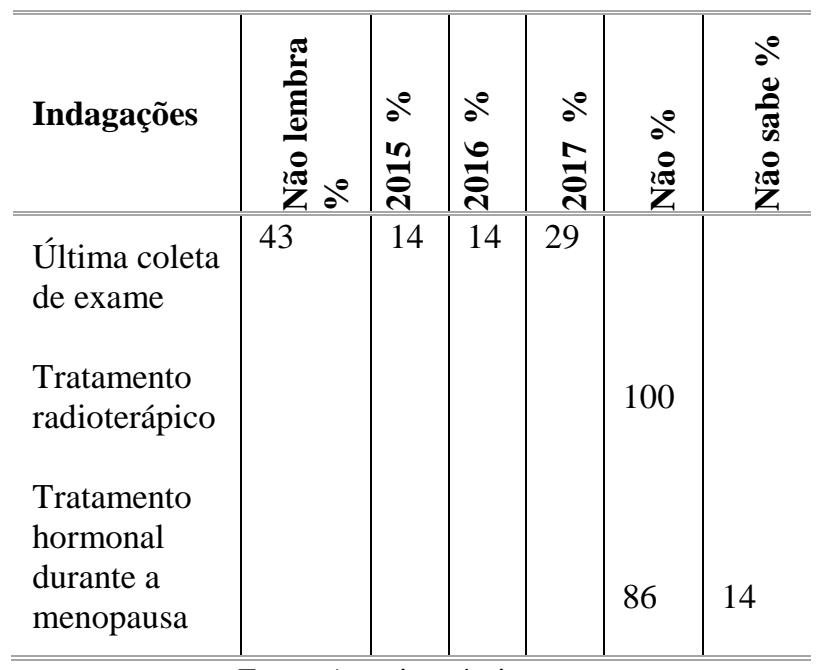

Fonte: Autoria própria.

Confirmando aos dados obtidos, sabe-se que a pouca procura à consulta ginecológica está arrolada com a vergonha que as usuárias sentem ao exibir seus genitais. De serem particularmente observadas e manuseadas por profissionais, com o medo do exame e do resultado, a demora em atendimento, o atendimento rápido e comum, a relação, despótica da equipe com a usuária, o espaço físico inapropriado, o atraso dos resultados dos exames e na marcação de consultas e a distância dos postos de saúde e sua residência. (BRITO; CAMARGO, 2011)

Para elucidar o que se pode observar acima, Catafesta $e t$ al. (2005) destaca que a consulta de enfermagem ginecológica utilizando o Processo de Enfermagem desenvolve atividades que visam melhorar a qualidade de vida e preparar a mulher para o autocuidado. Esta é de grande importância, pois possibilita ao enfermeiro desenvolver condições para sua atuação de forma direta e independente, corroborando com a autonomia profissional.

Acrescenta ainda que o acolhimento na consulta de enfermagem consente, para além da troca de saberes entre enfermeiro e usuária, a escuta atenta, na qual ela pode expor medos, ansiedades, preocupações ou dificuldades, exigindo do profissional uma percepção complexa sobre o indivíduo, o que culminará no planejamento de ações baseadas nas necessidades individuais de cada paciente. 
Portanto, deve ser trabalhada a questão da usuária como elemento participativo na prevenção das doenças, esclarecendo o exame ginecológico que, apesar de tão simples, é entendido pelas mulheres como algo vergonhoso, aflitivo e desconfortável, em razão de crenças, valores, conceitos e preconceitos estabelecidos.

A assistência clínico-ginecológica abrange o conjugado de ações e procedimentos voltados para a identificação, o diagnóstico e o tratamento imediato de patologias, por meio da anamnese e da avaliação clínica, conduzidas para a descoberta das patologias sistêmicas, especialmente, do aparelho reprodutivo, como também, prevenção das Doenças Sexualmente Transmissíveis (DST), do câncer cérvicouterino e da mama e a orientação sobre planejamento familiar. (INCA, 2010)

As pacientes ainda foram indagadas sobre qual profissional realizou a coleta de exames citopatológicos, constatando que das 56 mlheres que responderam ao questionário,71\% foi feita pelo médico e $29 \%$ pelo Enfermeiro. (Figura 3)

Figura 3 - Quantitativo Percentual dos Profissionais que realizam a coleta de exames citopatológicos de colo de útero

Coletia de exames citopatologicos de colo uterino

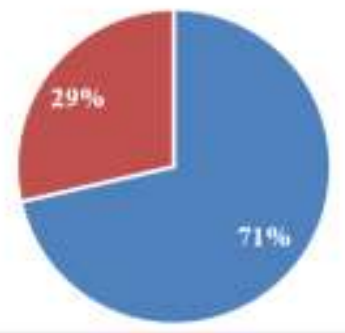

- Médico

- Profiscional de Enfemagai

Fonte: Autoria própria.

Nesta questão, observa-se a preferência das usuárias em realizar o exame com o médico. Contudo, as recomendações do Ministério da Saúde, é que ocorra com o Profissional de Enfermagem, pois a consulta de enfermagem em ginecologia é uma atividade que possibilita ao enfermeiro, situações para atuar de forma direta e autônoma com a usuária, distinguindo, sua autonomia profissional, como igualmente, favorecendo ajuda para a deliberação do diagnóstico de enfermagem e elaboração do plano assistencial, por fim, agindo como recurso para registrar sua prática.

Nota-se atualmente que existe necessidade do profissional, desde a sua formação acadêmica, desenvolver uma consciência específica relativa aos problemas de enfermagem, o que objetiva o seu descontentamento entre enfermeiro e usuária, face à consulta de enfermagem em ginecologia e seu valor, em conformidade com a Resolução COFEN-159/1993 o art. $\mathrm{n}^{\circ} 11$, inciso I da Lei $\mathrm{n}^{\circ} 7.498$, de 25 de junho de 1986, e no Decreto $n^{\circ}$ 94.406/87, que a regulamenta, validando a Consulta de Enfermagem e definindo como sendo uma atividade específica do enfermeiro (MOREIRA; SANTOS; LIMA, 2012).

De acordo com a lei do exercício profissional de enfermagem e da Lei $\mathrm{n}^{\circ} 2.604 / 55$ o profissional enfermeiro é diplomado a realizar o exame preventivo da neoplasia maligna do colo de útero desde que seja pós-graduada em obstetrícia, profissional de Saúde Pública (PSF). Percebe-se que, conforme a carência de profissionais diplomados nestas especialidades e diante da falta de informação destas leis pelos próprios enfermeiros, essa prática é desempenhada sem que haja tal especialização. Vale ressalvar que, em lugares carentes de pessoal técnico diplomado, tal prática sem a especialidade correta é prevista por legislações (MOREIRA; SANTOS; LIMA,2012).

Com base nestas legislações, a consulta de enfermagem é atividade privativa do enfermeiro com respaldo legal desde 1986, o qual incide no desenvolvimento de ações deliberadas e sistematizadas, pertinentes entre si, e que buscam promover ações de cuidado. Desta forma, comporta ao enfermeiro uma atuação direta e de maneira independente junto aos pacientes ou usuários dos serviços de saúde, atividade esta que coopera para o fortalecimento da autonomia profissional. (MOREIRA; SANTOS; LIMA,2012).

Constitui-se, pois, o acolhimento em uma importante ferramenta que permite maior acesso da usuária ao serviço de saúde, vindo a possibilitar a construção de vínculos, além de avaliação global e intervenção possivelmente mais resolutiva, consolidando-se, assim, as diretrizes do Sistema Único de Saúde (SUS). (LÍCIO; ZUFFI; FERREIRA,2013)

A Figura 4 apresenta uma lista de dificuldades encontradas pelos profissionais de Enfermagem na realização do exame de PCCU. Destes, o que apresentou maior índice referem-se à vergonha maior quando o profissional que submete ao exame é do sexo masculino (60\%), seguido da dificuldade de realização de diálogo (10\%) e dos aspectos psicológicos e culturais na realização do exame (8\%) e medo dos resultados $(8 \%)$ respectivamente. Os demais foram assinalados em menor percentual.

Figura 4 - Dificuldades encontradas pelo enfermeiro na realização do exame de PCCU

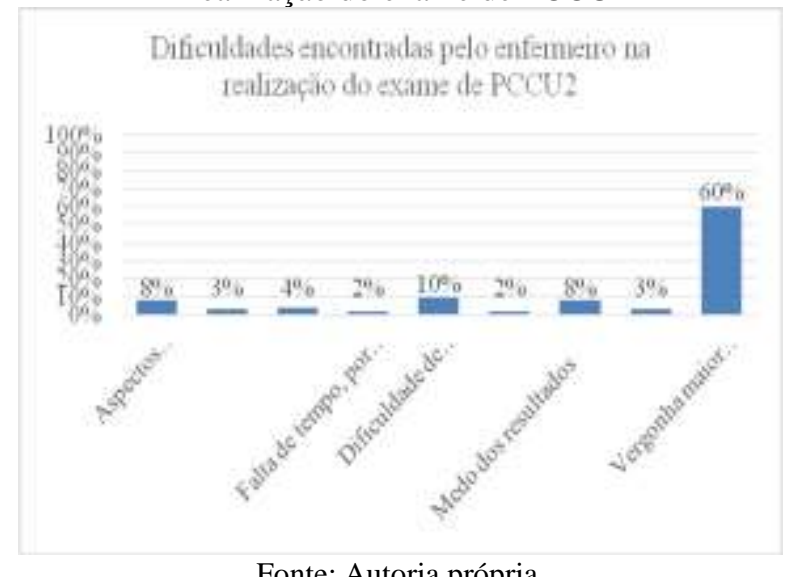

Fonte: Autoria própria.

Confirmando as dificuldades acima apresentadas, sabese que tais aspectos são influenciados pelas crenças e valores culturais, acompanhados de outras causas, como as relacionadas à organização dos serviços de saúde; a desinformação das mulheres sobre a doença; ainda a baixa escolaridade; a influência negativa do parceiro; e a falta de qualidade, de privacidade e de humanização no atendimento. Essas razões contribuem para a não adesão das mulheres à prática periódica do exame preventivo. (OLIVEIRA; ALMEIDA, 2009)

Partindo dessas premissas, cumpre relatar que o papel de educador merece destaque, pois, para uma prevenção, é imprescindível que a usuária seja estimulada a procurar os serviços de saúde de forma recorrente, ainda que não se apresentem manifestações de patologias (BRASIL,2013). Para que isso ocorra, demanda mudança de comportamento, pois a mulher não foi orientada para fazer consulta 
ginecológica buscando a preservação da saúde e, sim, para o tratamento.

Oliveira e Almeida (2009) corrobora na visão da importância do enfermeiro como membro participante da equipe de saúde nos programas de prevenção ligado à população feminina, não só como especialista, mas também como educador e conselheiro. $\mathrm{O}$ aconselhamento faz parte da atividade educativa, pelo qual se deve haver um diálogo particular do enfermeiro com a paciente, de modo que esta seja participante de todo o procedimento de prevenção e tratamento e ainda, capacitado a tomar decisões pessoais.

Por ser um aspecto extraordinário no atendimento, o aconselhamento e o diálogo devem ser mantidos, pois oportuniza ao profissional manter contato com a usuária durante a consulta, individualizando o acolhimento receptivo, informativo e integrador, o que promove o despertar da confiança e da empatia (TEIXEIRA et al., 2009). Portanto, no momento da consulta de enfermagem, deve o Profissional de Enfermagem dedicar atenção especial à comunicação.

\section{CONCLUSÃO}

A busca da usuária para a consulta ginecológica acontece, comumente, em virtude da manifestação de alguma intercorrência ginecológica, a qual pode ser de ordem orgânica, ou de ordem emocional; porém, pesquisas demonstram que a maior parte das mulheres só procura o atendimento clínico-ginecológico para a resolução de algum problema, não como uma prática de manutenção da saúde. Conclui-se que, no decorrer das atividades diárias, a atuação do profissional de saúde junto às usuárias, na expectativa de emancipá-las, vem acontecendo, e ao mesmo tempo, que a maioria dos projetos trabalhe o assunto com um enfoque meramente informativo. As abordagens devem ser educativas, com a finalidade de informá-las, para que reflitam sobre a importância da prevenção do câncer, para que assim, sejam protagonistas nesta relação.

É importante também, que se procure identificar as limitações do enfermeiro na realização da consulta ginecológica; analisando as dificuldades enfrentadas pela usuária, bem como, retratando de que forma se dá o acolhimento na consulta ginecológica, listando os passos importantes, especialmente, no que se refere a fatores de risco, diagnóstico e tratamento

O presente estudo apresenta limitações, considerando que há necessidade de mais investigações, e especialmente sugere-se a continuidade do estudo ampliando o universo do público alvo para todo o município foco do estudo, isto é, por não ter pesquisado as representações sociais das mulheres sobre prevenção do câncer cervical uterino após intervenção educativa e por sua amostra não representar os sujeitos do universo, restringindo as recomendações ao campo de estudo investigado

\section{REFERÊNCIAS}

BERGMAN, A. et al. Controle dos cânceres do colo do útero e da mama. Ministério da Saúde. Secretaria de Atenção à Saúde. Departamento de Atenção Básica. 2. ed. Cadernos de Atenção Básica, n. 13. Brasília-DF: Ministério da Saúde, 2013. Disponível em: <http://189.28.128.100/dab/docs/portaldab/publicacoes/cab1 3.pdf>. Acesso em 04 dez. 2017.
BRASIL. Ministério da Saúde. Secretaria de Atenção à Saúde. Departamento de Atenção Básica. Controle dos cânceres do colo do útero e da mama. Brasília: Ministério da Saúde, 2006.

BRASIL. Ministério da Saúde. Secretaria de Atenção à Saúde. Departamento de Atenção Básica. Rastreamento. Série A. Normas e manuais técnicos. Cadernos de Atenção Primária, n. 29. Brasília-DF: Ministério da Saúde, 2010, 95 p.

BRASIL. Ministério da Saúde. Instituto Nacional de Câncer José Alencar Gomes da Silva (INCA). Diretrizes brasileiras para o rastreamento do câncer do colo do útero. Rio de Janeiro: INCA, 2011a. Disponível em: <http://bvsms.saude.gov.br/bvs/publicacoes/inca/rastreament o_cancer_colo_utero.pdf>. Acesso em 13 jun. 2017.

BRASIL. Instituto Nacional de Câncer José Alencar Gomes da Silva (INCA). Estimativa 2012: incidência de câncer no Brasil. Rio de Janeiro: INCA; 2011b. 118 p. Disponível em: <http://portal.saude.sp.gov.br/resources/ses/perfil/gestor/hom epage/estimativas-de-incidencia-de-cancer-

2012/estimativas_incidencia_cancer_2012.pdf >. Acesso em 04 jun. 2017.

BRASIL. Ministério da Saúde. Secretaria de Atenção à Saúde. Departamento de Atenção Básica. Controle dos cânceres do colo do útero e da mama. Caderno de atenção Básica n.13. 2. ed. Brasília: Ministério da Saúde. 2013. Disponível em: <http://189.28.128.100/dab/docs/portaldab/publicacoes/cab1 3.pdf>. Acesso em 13 jun. 2017.

BRITO, A.M.M; CAMARGO, B.V. Representações sociais, crenças e comportamentos de saúde: um estudo comparativo entre homens e mulheres. Temas em psicologia. v. 29, p.283-303, 2011.

CATAFESTA, Gabriela et al. Consulta de Enfermagem Ginecológica na Estratégia Saúde da Família. Arquivos de Ciências da Saúde, v. 22, n. 1, p. 85-90, mar. 2015. Disponível em <http://www.cienciasdasaude.famerp.br/index.php/racs/articl e/view/32>. Acesso em: 12 dez. 2018.

INCA. Instituto Nacional de Câncer (BRASIL). Plano de ação para redução da incidência e mortalidade por câncer do colo do útero: sumário executivo. Rio de Janeiro: 2010. 40 p. Disponível em: <http://bvsms.saude.gov.br/bvs/publicacoes/plano_acao_red ucao_cancer_colo.pdf>. Acesso em 15 dez. 2017.

INCA - Instituto Nacional de Câncer. Estimativa 2016: incidência de câncer no Brasil. Rio de Janeiro: 2015. Disponível

<http://www.inca.gov.br/wcm/dncc/2015/estimativa2016.asp>. Acesso em 15 dez. 2017.

LÍCIO, F.C; ZUFFI, F.B; FERREIRA, L.A. Concepção de enfermeiros de saúde da família sobre a consulta de enfermagem ginecológica. Rev Pesqui Cuid Fundam.v.5, n.4, p.566-573, 2013.

MELO, S. C. C. S. et al. Alterações citopatológicas e fatores de risco para a ocorrência do câncer de colo uterino. Revista gaúcha de enfermagem, Porto Alegre, v. 30, n. 4, p. 602608, 2009. Disponível em: <http://www.scielo.br/pdf/rgenf/v30n4/a04v30n4.pdf>. Acesso em 28 jun. 2017. 
MOREIRA, M.S., SANTOS, S.M.C.; LIMA, M.K.C. Consulta de enfermagem no ambulatório de HIV/AIDS: a percepção dos usuários. Revista gaúcha de enfermagem, Porto Alegre, v. 33, n.33, p.52-75, 2012.

NARCHI, N. Z; FERNANDES, R. A. Enfermagem e saúde da mulher. 2. ed. São Paulo: Manole, 2013.

NASCIMENTO, L. C. Representações sociais da prevenção do câncer de colo cervico-uterino elaboradas por mulheres. 2010. 92f. Dissertação (Mestrado em Enfermagem) - Universidade Federal do Piauí. Terezina: 2010.

OLIVEIRA, S.L.; ALMEIDA A.C.H.A. Percepção das mulheres frente ao exame de papanicolau: da observação ao atendimento. Cogitare Enferm. v. 14, p..518-2526, 2009.

PARADA, R. et al. A política nacional de atenção oncológica e o papel da atenção básica na prevenção e controle do câncer. Rev. APS, Juiz de Fora, v.11, n. 2, p.199 - 206, abr./jun. 2008.

SILVA, S. E. D. et al. Representações sociais de mulheres amazônicas sobre o exame Papanicolau: implicações para a saúde da mulher. Esc. Anna Nery. Rev. Enferm., Rio de Janeiro, v. 12, n. 4, p. 685-692, 2008. Disponível em: <http://www.scielo.br/pdf/ean/v12n4/v12n4a12.pdf>. Acesso em 15 mai. 2017.

SOARES, M.C. et al. Câncer de colo uterino: atenção integral à mulher nos serviços de saúde. Revista Gaúcha de Enfermagem, v.32, p. 502-508, 2011.

TEIXEIRA CAB, SILVA RM, RODRIGUES MSP, LINARD AG, DIÓGENES MAR, MENDONÇA FAC. Comunicação interpessoal como instrumento que viabiliza a qualidade da consulta de enfermagem ginecológica. Rev. APS; v.12 n.1. p. 16-28, 2009.

TEIXEIRA, E.H.M., QUEIROZ, A.B.H., MOTA, M.S.C., CARVALHO, M.C.M.P.; COSTA, E.P.S. Saúde da mulher na perspectiva a assistência prestada pela enfermagem ginecológica: um relato de experiência. Cad. Espaço Fem. v.6, n.1, p. 179-89, 2013.

VALE, D. B. A. P. et al. Avaliação do rastreamento do câncer do colo do útero na Estratégia Saúde da Família no Município de Amparo, São Paulo. Cad. Saúde Pública, Rio de Janeiro, v. 26, n. 2, p. 383-390, 2010. Disponível em: <http://www.scielo.br/pdf/csp/v26n2/17.pdf>. Acesso em 23 jun. 2017.

VASCONCELOS, C. T. M. et al. Revisão integrativa das intervenções de enfermagem utilizadas para detecção precoce do câncer cérvico-uterino. Revista LatinoAmericana, Fortaleza, v. 19, n. 2, p.1-8, mar./abr., 2011. Disponível

em:<http://www.scielo.br/pdf/rlae/v19n2/pt_28.pdf>. Acesso em 21 jun. 2017.

\section{COPYRIGHT}

Direitos autorais: Os autores são os únicos responsáveis pelo material incluído no artigo. 


\section{Área: Ciências Agrárias e Biológicas}

\begin{tabular}{|c|c|}
\hline $4-1$ & $\begin{array}{l}\text { AVALIAÇÃO DO ESTRESSE NA TRIPULAÇÃO DE RESGATE AEROMÉDICO } \\
\text { STRESS ANALYSIS OF AEROMEDICAL RESCUE CREW } \\
\text { Luis Fernando Wu; Fernanda Yamashita; Letícia De Oliveira Cardoso; Nick } \\
\text { Chang; Rafael Rick Matsuo De Carvalho; Júnia Shizue Sueoka }\end{array}$ \\
\hline $5-7$ & $\begin{array}{l}\text { PRODUÇÃO DE PÃES E MASSAS FRESCAS EMPREGANDO DIFERENTES } \\
\text { PERCENTUAIS DE FARINHA DE CENOURA EM SUBSTITUIÇÃO À FARINHA DE } \\
\text { TRIGO } \\
\text { PRODUCTION OF BREADS AND FRESH PASTS BY EMPLOYING DIFFERENT } \\
\text { PERCENTAGES OF CARROT FLOUR IN REPLACEMENT OF WHEAT FLOUR } \\
\text { Betina Mariela Barreto; Ana Lúcia Becker Rohlfes; Nádia De Monte Baccar; Liliane } \\
\text { Marquardt }\end{array}$ \\
\hline
\end{tabular}




\title{
Revista SODEBRAS - Volume 14 \\ $\mathrm{N}^{\circ} 157$ - JANEIRO/ 2019
}

\section{AVALIAÇÃO DO ESTRESSE NA TRIPULAÇÃO DE RESGATE AEROMÉDICO}

\section{STRESS ANALYSIS OF AEROMEDICAL RESCUE CREW}

\author{
LUIS FERNANDO WU ${ }^{1}$, FERNANDA YAMASHITA ${ }^{1}$, LETÍCIA DE OLIVEIRA CARDOSO ${ }^{1}$, NICK \\ CHANG, RAFAEL RICK ${ }^{1}$ MATSUO DE CARVALHO ${ }^{1}$, JÚNIA SHIZUE SUEOKA ${ }^{1}$ \\ 1 - UNIVERSIDADE DE MOGI DAS CRUZES \\ luis.wu75@gmail.com; fernanda.yamashita@outlook.com; leticia_oliveiracardoso@hotmail.com; \\ nickchang_nike@hotmail.com; rafaelrickmatsuo@yahoo.com.br; jsueoka@yahoo.com.br
}

\begin{abstract}
Resumo - Este estudo teve como objetivo avaliar o estresse nas equipes de resgate aeromédico das cidades de São Paulo (SP), Maringá (PR) e Varginha (MG). A pesquisa foi realizada com 72 participantes, divididos por funções (tripulação, piloto, enfermeiro e médico). Para obtenção dos objetivos foi realizado um estudo de abordagem quantitativa e transversal consistindo na aplicação de dois questionários: Caracterização do perfil sociodemográfico e o Inventário de Sintomas de Stress para Adultos de Lipp na equipe de resgate aeromédico; e realizado o tratamento estatístico dos dados. Os resultados revelaram que $26 \%$ dos participantes apresentavam estresse, sendo que $84 \%$ situam-se na fase resistência, $5 \%$ na fase alerta e $11 \%$ na fase quase-exaustão. Em pilotos e enfermeiros o estresse físico predominou, enquanto que nos tripulantes e médicos foi o psicológico. Conclui-se que é necessário investigar os níveis de estresses desses profissionais.
\end{abstract}

Palavras-chave: Estresse. Resgate. Aeromédico.

Abstract - This article aims to evaluate stress in the aeromedical rescue crews in the cities of São Paulo (SP), Maringá (PR)e Varginha (MG). The survey was performed with 72 participants, divided by functions (crew, pilot, nurse and doctor). To obtain the results, we performed a transversal and quantitative study consisted of the application of two questionnaires: Characterization of the biodemographic profile and the Inventory of Symptoms of Stress for Adults of Lipp to the aeromedical rescue crew with statistical analysis of the data. The results revealed that $26 \%$ of the participants were diagnosed with stress, with $84 \%$ of the cases occurring in the resistance phase, $5 \%$ in the alert phase and $11 \%$ in the near-exhaustion phase. In pilots and nurses the physical stress predominated, whereas in the crew and doctors it was the psychological. In conclusion, it is necessary to investigate the levels of stress of these professional's.

Keywords: Stress. Rescue. Aeromedical

\section{INTRODUÇÃO}

Atualmente existem diversos significados para o estresse, Helman (2009) o define como um conjunto de reações do organismo às agressões de origens diversas, capazes de perturbar o equilíbrio interno; quando intensificado, há um desequilíbrio no organismo, evidenciando que a reação ao estresse é uma atitude biológica necessária para uma adaptação do indivíduo às situações novas.

A adaptação desenvolvida pelo organismo humano é descrita por Selye (1956) apresentando três fases distintas, sendo elas: (1) fase do alarme, a qual se inicia após o confronto com o estressor, podendo ser consciente ou não, é uma mobilização química como uma reação comum do corpo que necessita atender às exigências, ou seja, o preparo da ação; (2) fase da resistência, sendo este o estágio em que o corpo luta para a sobrevivência e para a adaptação; (3) fase da exaustão, caracterizada pelo momento em que o estressor e o corpo não conseguiram o equilíbrio, não ocorrendo à adaptação, tendo como consequência o possível surgimento de doenças diversas (úlcera, hipertensão arterial, artrites e lesões miocárdicas) ou ocasionando até mesmo a morte (HELMAN, 2009). Entretanto Lipp (2013) ao validar o Inventário de Sintomas de Stress para Adultos (ISSL) identificou, tanto clínica como estatisticamente, uma fase transitória entre resistência e exaustão, denominada fase quase-exaustão, período em que o corpo não consegue resistir ou adaptar-se ao estressor, tornando-se vulnerável às doenças preestabelecidas na fase de exaustão.

As missões de resgate aeromédico são de alto risco associado, por diversos motivos como: caráter de urgência do socorro a uma vítima com risco de morte iminente, no qual o tempo é um agravante da sua condição de saúde; vôo em áreas urbanas; pouso em locais não preparados e a auto pressão imposta pela equipe para executar a missão (CARDOSO et al., 2017).

Segundo Kessler (2015), observou que o uso de helicópteros nas missões de resgate aeromédico está entre os quatro primeiros na lista de acidentes com helicópteros. E neste panorama aeronáutico, as causas dos acidentes aéreos ocorrem principalmente por perda de controle em vôo, e dentre os fatores contribuintes destaca-se o julgamento do piloto e o erro humano que está fortemente associado ao estresse (ALMEIDA et al., 2016).

Em relação aos profissionais da área da saúde, o estresse é um dos principais fatores que ocasionam erros na conduta decidida, nos procedimentos e avaliações pré-hospitalares (PHTLS, 2016). Os estressores com que essas profissões lidam são explicados pela experiência de trabalhar com pessoas que estão enfermas e em condições críticas de saúde, alta exigência do local de trabalho, longas jornadas de trabalho devido ao regime de turnos e plantões, permitindo os duplos empregos (PAFARO \& MARTINO, 2004; SCHOLZE et al., 2017), a maior chance de sofrerem psicologicamente, tendo em vista a complexidade das ações ali realizadas, o estresse 
gerado durante a sua abordagem e a ocorrência de morte de pacientes durante o resgate de pacientes críticos (MACÊDO et al., 2018).

Esta pesquisa parte do pressuposto que a tripulação que realiza o aero resgate com helicóptero sofre com os fatores estressantes ocupacionais que exigem do organismo uma reação ou adaptação (LIPP, 2013) e que as funções exercidas por cada profissional (médico, piloto, enfermeiro e tripulação) e outros estressores (físico e ambiente) possam gerar sintomatologia física ou psicológica (TAJVAE et al., 2015).

O objetivo da presente pesquisa foi avaliar o estresse da tripulação que realiza o resgate aeromédico, uma vez que, em níveis acentuados, além dos problemas de saúde físicos e mentais, as probabilidades da ocorrência de erros são maiores, comprometendo a segurança da tripulação e a eficácia no tratamento do paciente.

\section{PROCEDIMENTOS}

A metodologia do estudo foi quantitativa e transversal. Participaram do estudo 72 profissionais das seguintes localidades: Grupamento de Radiopatrulha Aérea da Polícia Militar (ÁGUIA) e Grupo de Resgate e Atendimento a Urgências (GRAU) do estado de São Paulo, do SAMU aéreo do município de Maringá - PR e do Corpo de Bombeiro aéreo do município de Varginha - MG, de ambos os gêneros e faixa etária entre 25 e 60 anos, obrigatoriamente participantes da tripulação do resgate aeromédico, que apresentaram disponibilidade para responder o questionário e concordaram em assinar o Termo de Consentimento Livre Esclarecido (TCLE), mantendo em sigilo a identidade dos participantes. O projeto foi aprovado pela Comissão de Ética e Pesquisa pelo CEP (CAAE 59172416.5.0000.5497).

Para a coleta de dados foi utilizado o Inventário de Sintomas de Stress para Adultos de LIPP (ISSL), validado e padronizado pelo Conselho Regional de Psicologia (LIPP \& GUEVARA, 1994). O questionário permite a identificação de quadros característicos do estresse, possibilitando diagnosticar o estresse em adultos e a fase em que a pessoa se encontra (alerta, resistência, quase-exaustão e exaustão). Baseia-se em um modelo quadrifásico e propõe um método de avaliação do estresse que enfatiza a sintomatologia somática e psicológica etiologicamente a ele ligada. O teste é composto por três subitens, sendo o primeiro quadro referente aos sintomas físicos ou psicológicos que o indivíduo tenha experimentado nas últimas 24 horas; o segundo, relacionado aos sintomas experimentados na última semana; e o terceiro quadro, referente a sintomas experimentados no último mês. De acordo com o resultado obtido, o indivíduo pode ser classificado como apresentando ou não estresse. Em caso positivo, é apontada a fase na qual se encontra e se a sintomatologia é predominantemente física ou psicológica. Houve também a utilização do questionário de caracterização sociodemográfico com um total de quatro perguntas, com o objetivo de verificar alguns dados complementares como: idade, tempo profissional, tempo de serviço na atividade aérea e se tem outro trabalho.

O procedimento para a aplicação do teste "Inventário de Sintomas de Stress para Adultos de LIPP" (ISSL) seguiu todas as regras e orientações citadas no manual do referido teste psicológico, inclusive a presença de um psicólogo para sua aplicação. Destaca-se que todos os participantes receberam explicação prévia da pesquisa e esclarecimento de eventuais dúvidas.
Após a obtenção dos dados através dos questionários, as informações coletadas foram organizadas e processadas em um banco de dados, sendo realizado o tratamento estatístico qualitativo a partir da análise das respostas de cada participante. Assim sendo, verificou-se a prevalência do estresse na tripulação, a fase em que se encontrava cada profissional e uma correlação do estresse com a função exercida no resgate aéreo.

\section{RESULTADOS E DISCUSSÃO}

Do total da população analisada, cuja amostra é composta de 72 profissionais do resgate aeromédico, a prevalência de participantes é do sexo masculino $82 \%(n=59)$ e as características sociodemográficas estão apresentadas na Tabela 1.

Em relação a ter outro emprego além do resgate, verificou-se que $46 \%(n=33)$ exerciam sua profissão em outro local. Destaca-se que desses 33 profissionais, 17 eram médicos e 16 enfermeiros. Em contrapartida, os pilotos e tripulantes trabalhavam apenas no resgate aeromédico.

Tabela 1 - Identificação dos participantes, conforme faixa etária, tempo profissional e tempo no resgate aéreo

\begin{tabular}{|c|c|c|}
\hline Variáveis & $\mathbf{n}$ & $\%$ \\
\hline \multicolumn{3}{|l|}{ Faixa Etária (anos) } \\
\hline $25-34$ & 21 & $29 \%$ \\
\hline $35-44$ & 35 & $49 \%$ \\
\hline $45-54$ & 15 & $21 \%$ \\
\hline $55-65$ & 1 & $1 \%$ \\
\hline Total & 72 & $100 \%$ \\
\hline \multicolumn{3}{|l|}{ Tempo profissional (anos) } \\
\hline $0-4$ & 3 & $4 \%$ \\
\hline $5-9$ & 13 & $18 \%$ \\
\hline $10-14$ & 17 & $24 \%$ \\
\hline $15-19$ & 12 & $17 \%$ \\
\hline $20-24$ & 17 & $24 \%$ \\
\hline $25+$ & 10 & $14 \%$ \\
\hline Total & 72 & $100 \%$ \\
\hline \multicolumn{3}{|c|}{ Tempo no resgate aéreo (anos) } \\
\hline $0-4$ & 40 & $56 \%$ \\
\hline $5-9$ & 14 & $19 \%$ \\
\hline $10-14$ & 7 & $10 \%$ \\
\hline $15-19$ & 7 & $10 \%$ \\
\hline $20-25$ & 4 & $6 \%$ \\
\hline Total & 72 & $100 \%$ \\
\hline
\end{tabular}

O resultado do ISSL revela que $26 \% \quad(n=19)$ dos participantes apresentaram o sintoma de estresse, portanto foi elaborada a Tabela 2 que consistiu no diagnóstico de estresse em diferentes variáveis (faixa etária, tempo profissional e tempo no resgate aéreo).

Ao realizar o teste de Qui-quadrado para avaliar uma possível relação entre as variáveis pesquisadas, foi possível verificar que não houve associação estatisticamente significativa entre estresse e as variáveis faixa etária e tempo profissional $(\mathrm{p}>0,05)$. 
Entretanto observou-se que nos profissionais com menos tempo no serviço de resgate aéreo foram mais suscetíveis a apresentarem sintomas de estresse $(\mathrm{p}<0,05)$, uma vez que, o recém profissional precisa se adaptar a equipe e ao ambiente de trabalho podem gerar um estresse nesses profissionais. Segundo Cardoso et al. (2017) realizando um questionário na equipe de resgate aeromédico de São Paulo verificou que a interação entre a tripulação é fundamental para a segurança operacional e para que se atinja um alto grau de desempenho e sinergia na equipe. Outro fator que pode estar relacionado ao estresse dos recém admitidos é a instabilidade profissional e na carreira (GOMES et al., 2009).

Tabela 2 - Presença ou ausência de estresse (n/\%) em relação à faixa etária, tempo profissional e tempo no resgate aéreo de profissionais do resgate aéreo da cidade de São Paulo, Maringá e Varginha

\begin{tabular}{lllll}
\hline \multirow{2}{*}{ Variáveis } & \multicolumn{5}{c}{ Presença de estresse } \\
\cline { 2 - 6 } & Sim & Não \\
\hline Faixa Etária (anos) & $\mathrm{n}$ & $\%$ & $\mathrm{n}$ & $\%$ \\
$25-34$ & 4 & 19 & 17 & 81 \\
$35-44$ & 14 & 40 & 21 & 60 \\
$45-54$ & 1 & 7 & 14 & 93 \\
$55-65$ & 0 & 0 & 1 & 100 \\
\hline Total & 19 & & 53 & \\
\hline
\end{tabular}

Tempo profissional (anos)

\begin{tabular}{lllll}
$0-4$ & 1 & 33 & 2 & 67 \\
$5-9$ & 3 & 23 & 10 & 77 \\
$10-14$ & 3 & 18 & 14 & 82 \\
$15-19$ & 6 & 50 & 6 & 50 \\
$20-24$ & 5 & 29 & 12 & 71 \\
$25+$ & 1 & 10 & 9 & 90 \\
\hline Total & 19 & & 53 \\
\hline
\end{tabular}

Tempo no resgate aéreo (anos)

\begin{tabular}{lllll}
$0-4$ & 12 & 30 & 28 & 70 \\
$5-9$ & 3 & 21 & 11 & 79 \\
$10-14$ & 3 & 43 & 4 & 57 \\
$15-19$ & 1 & 14 & 6 & 86 \\
$20-25$ & 0 & 0 & 4 & 100 \\
\hline Total & 19 & 53 \\
\hline
\end{tabular}

Fonte: Autores, 2018.

De acordo com o diagnóstico do estresse por caracterização da fase em que se encontram os participantes sintomáticos, $84 \%(n=16)$ situaram-se na forma prevalente, a fase de "resistência"; $5 \%(\mathrm{n}=1)$ na fase de "alerta" e $11 \%$ $(\mathrm{n}=2)$ na fase de "quase-exaustão" (Figura 1).

Diniz et al. (2006) aplicando o ISSL em 15 pilotos de helicóptero da equipe de resgate de São Paulo verificou que 6 pilotos apresentavam estresse sendo $83 \%(n=5)$ na fase resistência e $17 \%(\mathrm{n}=1)$ na fase quase exaustão.

Apesar dos resultados estarem próximos dos valores obtidos desse estudo, destaca-se que o presente trabalho avaliou outras profissionais que estão envolvidas no resgate aéreo, portanto foi realizada uma análise de outros trabalhos envolvendo esses profissionais.
Macêdo et al. (2018) analisando o estresse em médicos e enfermeiros de duas UTIs do Ceará, verificou que $17 \%$ e $8 \%$, respectivamente, médicos e enfermeiros apresentaram estresse e todos estavam na fase resistência. No entanto Kestenberg et al. (2015) avaliando o estresse da equipe de enfermagem de diferentes unidades de um hospital universitário, cerca de $56,5 \%$ apresentaram estresse e desses enfermeiros apenas $4,7 \%$ encontraram-se na fase quase exaustão e $49,4 \%$ na fase resistência.

Outro estudo avaliando o nível de estresse de médicos em uma unidade de emergência psiquiátrica verificou-se que $66 \%$ da equipe médica apresentavam estresse na fase resistência do tipo psicológico, sendo o principal sintoma a insônia podendo resultar na diminuição da memória, sentimento de insatisfação constante, baixo rendimento profissional e aumento do risco de acidentes de trabalho (ZACHARIAS et al., 2016). De acordo com Cardoso (2013), estudando o nível de estresse dos tripulantes que participavam do resgate aéreo do Corpo de Bombeiro de Santa Catarina, verificou-se que $22 \%$ dos profissionais manifestavam sintomas psicológicos e estavam na fase de resistência.

Embora o estresse seja considerado um dos problemas que mais afeta o ser humano, interferindo na homeostase, podemos observar que nas fases de resistência e alerta o corpo possui mecanismos de adaptação que, ao intensificarem a função do sistema parassimpático, diminuem o estresse para níveis basais (FINK, 2016; BRULÉ \& MORGAN, 2018).

Por outro lado, quando os estressores são intensos e os mecanismos de defesa insuficientes para manter o equilíbrio, os indivíduos evoluem para a fase quase exaustão ou exaustão, podendo apresentar sintomas físicos e psicológicos que comprometem negativamente sua função cognitiva, favorecendo a ocorrência de erros (KUPRIYANOV \& ZHDANOV, 2014).

Figura 1 - Porcentual dos profissionais do resgate aéreo da cidade de São Paulo, Maringá e Varginha que apresentaram estresse representado em cada fase do estresse, segundo avaliação do ISSL e

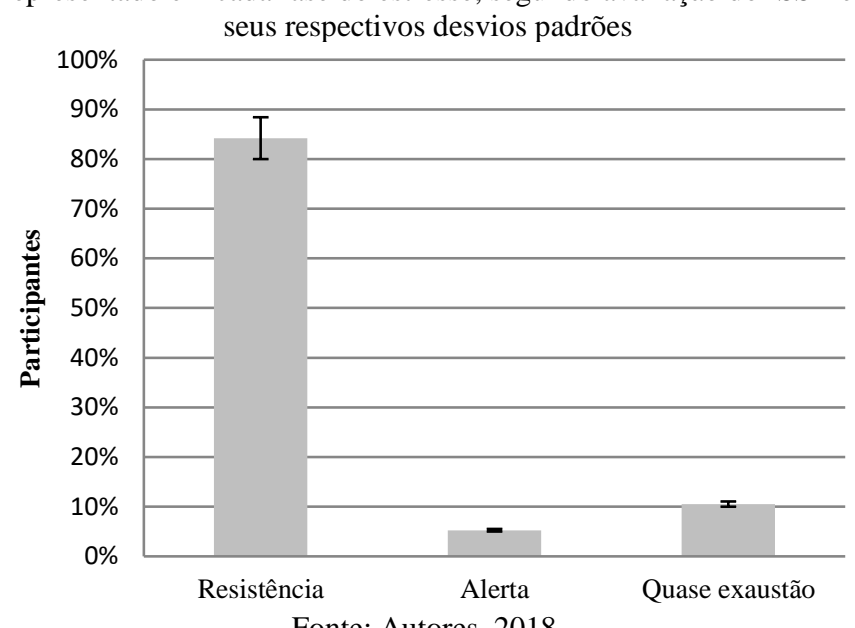

Fonte: Autores, 2018.

A Figura 2 apresenta a sintomatologia de estresse nos participantes diagnosticados. Observa-se que em $47 \%$ dos participantes com estresse há a apresentação de sintomas físicos e em $10 \%$ verifica-se a presença de sintomas psicológicos e físicos, entretanto esses profissionais são mais afetados pelos sintomas psicológicos, uma vez que a prevalência é de $63 \%$ dos entrevistados. Corroborando com os resultados, Diniz et al. (2006) observou que $57 \%$ da sua amostra apresentaram sintomatologia psicológica, sugerindo o desgaste mental da profissão. 
Figura 2 - Porcentual dos profissionais do resgate aéreo da cidade de São Paulo, Maringá e Varginha que apresentaram estresse representado quanto a sua sintomatologia e seus respectivos desvios padrões.

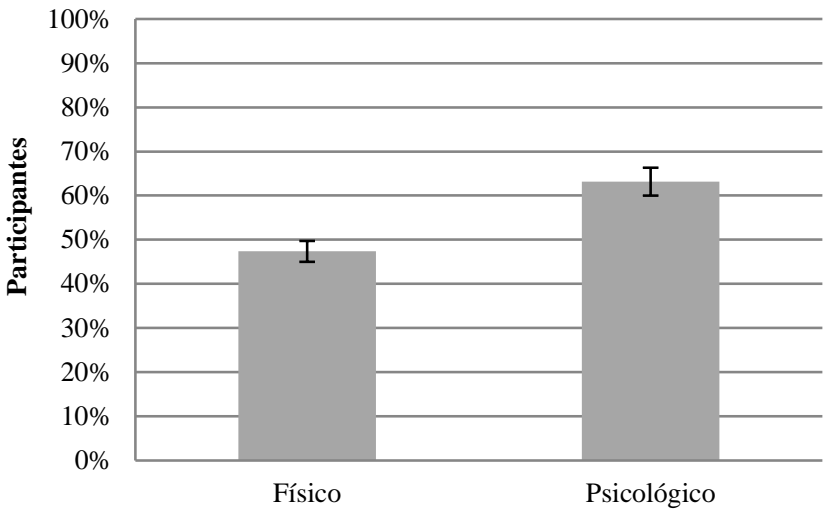

Fonte: Autores, 2018.

Uma vez que diferentes ocupações possuem estressores ocupacionais específicos, como os pilotos de helicópteros, que têm como função principal pilotar a aeronave e, quando em solo, garantir a segurança da aeronave enquanto a equipe médica estiver realizando o atendimento à vítima. $\mathrm{O}$ tripulante é responsável pela comunicação das equipes de controle e coordenação aeronáutica, como as equipes e viaturas em solo, além de auxiliar o piloto na navegação. $\mathrm{O}$ médico, geralmente um tripulante civil, é responsável pelo atendimento a vítima e pela segurança do lado direito do helicóptero durante pousos e decolagens. $\mathrm{O}$ enfermeiro auxilia o médico no atendimento ao paciente, é responsável pela segurança do lado esquerdo da aeronave e da navegação visual da base até o local da ocorrência (KUBE, 2010; CARDOSO et al., 2017). Portanto, elaborou-se a Tabela 3 correlacionando o tipo de estresse (físico ou psicológico) em cada ocupação avaliada.

Tabela 3 - Avaliação dos sintomas físicos e psicológicos dos profissionais do resgate aéreo da cidade de São Paulo, Maringá e Varginha conforme a ocupação que exerce no resgate aéreo.

\begin{tabular}{lcccccc}
\hline \multirow{2}{*}{ Ocupação } & \multicolumn{5}{c}{ Sintomas } \\
\cline { 2 - 7 } & \multicolumn{2}{c}{ Frico } & \multicolumn{2}{c}{ Psicológico } & \multicolumn{2}{c}{ Assintomáticos } \\
\cline { 2 - 7 } & 3 & 33 & 1 & 8 & 9 & 17 \\
\hline Piloto & 1 & 11 & 4 & 33 & 19 & 36 \\
Tripulante & 3 & 33 & 3 & 25 & 12 & 23 \\
Enfermagem & 2 & 22 & 4 & 33 & 13 & 25 \\
Médico & 9 & 100 & 12 & 100 & 53 & 100 \\
\hline Total & \multicolumn{7}{c}{ Fonte: Autores, 2018. }
\end{tabular}

Observa-se que os pilotos e enfermeiros manifestam principalmente sintomas físicos. Provavelmente a postura assimétrica e estática desses profissionais reflete diretamente quadros dolorosos em regiões musculares (Diniz et al., 2006). Para os médicos e tripulantes verifica-se a prevalência de sintomas psicológicos, relacionados às funções que exercem uma pressão psicológica, uma vez que toda coordenação e comunicação entre equipes é de responsabilidade do tripulante. Enquanto o médico, durante todo o trajeto, com as informações adquiridas, necessita prever as condições do paciente e elaborar uma abordagem eficaz para a vítima, além de monitorar as condições vitais do paciente (PHTLS, 2017).
Apesar dos estudos revelarem que os atendimentos de urgência, pré hospitalar e resgate aeromédico serem atividades potencialmente estressoras, dado confirmado pela alta incidência de estresses nesses profissionais (MENDES, et al., 2011; CARDOSO et al., 2017). Nosso estudo apresentou baixa ocorrência de estresse, com os indivíduos estando, em sua maior parte, na fase de resistência. Esses dados sugerem que os profissionais avaliados, de maneira consciente ou inconsciente, utilizam-se de mecanismos cognitivos e/ou comportamentais que diminuem o estresse (BURTON et al., 2016). Ressalta-se ainda de que o estresse é um fenômeno singular que está associado à percepção de cada indivíduo, ou seja, os fatores potencializadores de estresse nem sempre são os mesmos para todas as pessoas (SOUZA et al., 2014).

\section{CONCLUSÃO}

Constatou-se que uma minoria dos profissionais que atuam no resgate aeromédico da cidade de São Paulo, Maringá e Varginha apresentou estresse.

Foi verificado também que a fase de resistência é prevalente nos participantes com o diagnóstico de estresse. Sabendo-se que em tal fase o corpo gasta energia para tentar restabelecer o equilíbrio interno, existe a predisposição de cometerem erros.

Portanto, é necessário investigar os estressores presentes na vida desses profissionais, uma vez que em níveis acentuados de estresse, podem comprometer a segurança da tripulação e a qualidade do trabalho.

Evidenciou-se, assim, a necessidade de políticas voltadas à realização de trabalhos preventivos e/ou de tratamento destinados a essas equipes de resgate aeromédico, bem como de ações que venham contribuir para sua motivação e autoestima, e tornando-as mais capacitadas e preparadas para os desafios dessa profissão.

Por fim, sobre as limitações deste estudo, ressalta-se que os resultados encontrados não podem ser generalizados para outros serviços com alta incidência de estresse, uma vez que se diagnosticou um serviço específico. Outra limitação é que a pesquisa que se limitou a 3 cidades que possuem o serviço de resgate aeromédico, não contemplando outras localidades.

Futuros estudos necessitam expandir os dados obtidos para outras regiões, para caracterizar os níveis de estresse, as fases em que se encontram e a qualidade de vida dos profissionais de outras localidades.

\section{REFERÊNCIAS}

ALMEIDA, C. A.; FARIAS, J. L.; SANTOS, L. C. B.; SANTOS, F. F.; AZEVEDO, C. P. C.; MATHEUS, F. L.; SERRA, L. A. Ocorrências aeronáuticas: Panorama Estatístico da aviação. Centro de Investigação e Prevenção de Acidentes Aeronáuticos (CENIPA), 2016.

BRULÉ, G.; MORGAN, R. Working with stress: can we turn distress into eustress? Journal of Neuropsychology \& Stress Management, v.3, p.1-3, 2018.

BURTON, A.; BURGESS, C.; DEAN, S.; KOUTSOPOULOU, G.Z.; JONES, S.H. How effective are mindfulness-bases interventions for reducing stress among healthcare professionals? A systematic reviem and metaanalysis. Stress and Health, v. 33 (1), p. 3-13, 2016.

CARDOSO, C. Avaliação do nível de estresse psicológico das tripulações e da equipe de apoio de solo do arcanjo - 
01. Trabalho de conclusão de curso em Gestão Pública, Florianópolis, 2013.

CARDOSO, R.G.; ABREU, B.S.M.; ZATTA, D.; BASTIANI, G.; ANDARDE, D. Análise da Aplicação dos Conceitos de Corporate Resource Management (CRM) Nas missões de Resgate Aeromédico no Grupamento de Radiopatrulha Aérea João Negrão (GRPAE). Revista Conexão Sipaer, v. 8 (2), p. 13-20, 2017.

DINIZ, K. C.; GONZALEZ, T. O.; ARANTES, J. P.; PANHISA, E. L. S.; JÚNIOR, C. G. Correlação entre estresse e dor em pilotos de helicóptero do Grupamento de Rádio Patrulha Aérea da Policia Militar na cidade de São Paulo. Fisioterapia Brasil, v. 7 (1), p. 44-48, 2006.

FINK, G. Stress: Concepts, Cognition, Emotions, and Behavior. Edition Handbook of stress Series volume 1, 2016.

GOMES, A. R.; CRUZ, J. F.; CABANELAS, S. Estresse ocupacional em profissionais de saúde: um estudo com enfermeiros portugueses. Psicologia: Teoria e Pesquisa, v. 25 (3), p. 307-318, 2009.

HELMAN, C. G. Cultura, Saúde e Doença, $5^{\circ}$ ed., Ed. Artmed, 2009.

KESSLER, C. Helicopter emergency medical service: motivation for focused research. CEAS Aeronautical Journal, v. 6, (3), p. 337-394, 2015.

KESTENBERG, C.C.F.; FELIPE, I.C.V.; ROSSONE, F.O.; DELPHIM, L.M.; TEOTONIO, M.C. O estresse do trabalhador de enfermagem: estudo em diferentes unidades de um hospital universitário. Revista de enfermagem da UERJ, v. 23 (1), p. 45-51, 2015.

KUBE, L.C. Fisiologia da fadiga, suas implicações na saúde do aviador e na segurança na aviação. Revista Conexão Sipaer, v. 2 (1), p. 35-57, 2010.

KUPRIYANOV, R.; ZHDANOV, R. The eustress concept: problems and outlooks. World Journal of Medical Sciences, v.11 (2), p.179-185, 2014.

LIPP, M. E. N. Stress na atualidade: qualidade de vida na família e no trabalho. Instituto de Psicologia e controle de Stress (IPCS), 2013.

LIPP, M.E.N.; GUEVARA, A.J.H. Validação empírica do inventário de sintomas de stress (ISS). Estudos Psicologia, v. 11(3), p. 43-49, 1994.

MACÊDO, A.T.S.; SOUSA, M.T.D.; GOMES, L.M.; ROLIM, M.A.B.; BASTO, J.E.P.; DANTAS, R.S.A.; BATISTA, H.M.T, LEITE, E.S. Estresse laboral em profissionais da saúde na ambiência da unidade de terapia intensiva. Revista Multidisciplinar e de Psicologia, v. 12 (42), p. 524-547, 2018.

MENDES, S.S.; FERREIRA, L.R.C.; MARTINO, M.M.F.; Identificação dos níveis de stress em equipe de atendimento pré-hospitalar móvel. Estudos de Psicologia, v. 28 (2), p199208, 2011.

PHTLS, Atendimento Pré Hospitalar ao Traumatizado: Comitê do PHTLS da National Association of Emergency Medical Technicions, GRUPO A, 8ºd., 2016.

SCHOLZE, A.R.; MARTINS, J.T.; ROBAZZI, M.L.C.C.; HADDAD, M.C.F.L.; GALDINO, M.J.Q.; RIBEIRO, R.P.
Estresse ocupacional e fatores associados entre enfermeiros de hospitais públicos. Cogitare Enfermagem, v. 22 (3), 2017.

SELYE, H. The stress of life. New York: Longmans, 1956.

SOUZA, D. J. D.; SOARES, J. C. C.; SANTOS, R. A.; ARAÚJO, T. C. C.; LEITE, T. S.; NAGAMINE.; V.H. S. O estresse e a qualidade de vida no ambiente de trabalho em organizações do semento de call Center. Psicologia v. 1, p. 123, 2014.

TAJVAE, A.; SARAJI, G. N.; GHANBARNEJAD, A.; OMIDI, L.; HOSSEINI, S. S. S.; Occupational stress and mental health among nurses in a medical intensive care unit of a general hospital in Bandar Abbas. Electronic Physician, v. 7 (3), p. 1180-1113, 2015.

ZACHARIAS, R.; SILVA, K.C.; CORREA, T.F.; DIAS, G.M.S.; MANSÃO, C.S.M.; BURIOLA, A.A. Avaliação do nível de estresse em equipe médica e de enfermagem em uma unidade de emergência psiquiátrica. Revista Uningá, v. 25 (3), p. 07-13, 2016.

\section{COPYRIGHT}

Direitos autorais: Os autores são os únicos responsáveis pelo material incluído no artigo.

Submetido em: 05/10/2018 Aprovado em: 26/11/2018 


\title{
Revista SODEBRAS - Volume 14 $\mathrm{N}^{\circ} 157$ - JANEIRO/ 2019
}

\section{PRODUÇÃO DE PÃES E MASSAS FRESCAS EMPREGANDO DIFERENTES PERCENTUAIS DE FARINHA DE CENOURA EM SUBSTITUIÇÃO À FARINHA DE TRIGO}

\author{
PRODUCTION OF BREADS AND FRESH PASTS BY EMPLOYING DIFFERENT \\ PERCENTAGES OF CARROT FLOUR IN REPLACEMENT OF WHEAT FLOUR
}

\author{
BETINA MARIELA BARRETO; ANA LÚCIA BECKER ROHLFES; NÁDIA DE MONTE BACCAR; \\ LILIANE MARQUARDT \\ UNIVERSIDADE DE SANTA CRUZ DO SUL - UNISC \\ bbarreto@mx2.unisc.br; albecker@unisc.br; nadia@unisc.br; liliane@unisc.br
}

\begin{abstract}
Resumo - A cenoura (Daucus carota L.) é um dos vegetais mais cultivados no Brasil, possui elevado teor de fibras e minerais e é uma matéria-prima de baixo custo. Objetivou-se desenvolver produtos com características funcionais $e$ posteriormente avaliar sua preferência de consumo. Foram elaboradas três formulações de pães e massas frescas, nas quais a farinha de trigo foi parcialmente substituída por farinha de cenoura $(10 \%, 15 \%$ e 20\%). Os produtos elaborados apresentaram maior teor de proteínas $e$ um baixo teor de gordura. A análise sensorial evidenciou a preferência dos provadores pelos pães elaborados com $15 \%$ de farinha de cenoura e massa fresca com $10 \%$ de farinha de cenoura. A elaboração de farinhas, a partir de vegetais in natura é uma alternativa para diminuir o desperdício de alimentos, bem como de vegetais não conformes.
\end{abstract}

Palavras-chave: Cenoura. Produtos Funcionais. Pães e Massas Frescas.

\begin{abstract}
The carrot (Daucus carota L.) is one of the most cultivated vegetables in Brazil, has high fiber and mineral content and is a low-cost raw material. The objective was to develop products with functional characteristics and later to evaluate their consumption preference. Three formulations of breads and fresh pasta were prepared, in which the wheat flour was partially replaced with carrot flour $(10 \%, 15 \%$ and $20 \%)$. The processed products had a higher protein content and a lower fat content. The sensorial analysis showed the preference of the tasters for the breads made with $15 \%$ of carrot flour and fresh pasta with $10 \%$ of carrot flour. The preparation of flours from fresh vegetables is an alternative to reduce the waste of food as well as non-compliant vegetables.
\end{abstract}

Keywords: Carrot. Functional Products. Breads and Fresh Pasts.

\section{INTRODUÇÃO}

A cenoura (Daucus carota L.) é uma importante fonte de carboidratos, fibras, minerais e uma das melhores fontes vegetais de carotenoides. Apresenta adaptabilidade a diferentes condições de cultivo e é considerada como uma das mais importantes hortaliças, devido ao elevado consumo mundial, extensão de área plantada e desenvolvimento socioeconômico dos produtores rurais. No Brasil encontra-se entre as cinco hortaliças mais cultivadas, com consumo per capita $1,25 \mathrm{~kg} / \mathrm{ano}$, sendo cultivada em todo o território nacional. Em 2016, a produção brasileira de cenoura foi de aproximadamente 800 de toneladas por ano (SANTOS et al., 2017). É uma planta da família das umbelíferas, produz uma raiz aromática e comestível, caracterizando-se como uma das mais importantes olerícolas (PEREIRA et al., 2014).

Destaca-se das outras hortaliças pela grande quantidade de vitamina A que possui, nutriente muito importante para a visão, na prevenção da cegueira noturna e xeroftalmia e no crescimento saudável das crianças. É rica em vitaminas como B1 e B2, $\beta$-caroteno (substância que lhe confere a cor laranjaavermelhada) e em sais minerais. As fibras, importantes para o funcionamento do intestino e a pectina, capaz de baixar a taxa de colesterol do organismo, são abundantes na cenoura e constituem mais uma razão para o seu uso na alimentação diária (RESENDE et al., 2016).

O $\beta$-caroteno é bom para a saúde dos olhos e da pele. Em razão da presença de vitamina $\mathrm{A}$, o consumo de cenoura reduz o risco de câncer e retarda o envelhecimento. Já, os sais minerais, contribuem para o bom equilíbrio do organismo e as vitaminas do complexo B ajudam a regular o sistema nervoso (JUNIOR \& OLIVEIRA, 2013).

A cenoura pode ser comercializada na forma de cubos, fios, palito, ralada e mini cenouras na preparação de saladas, sopas, refogados, bolos, cremes, suflês, doces, pães e massas (SILVA et al., 2016).

Conforme Correa et al. (2018), as cenouras começam a deteriorar poucos dias após a colheita quando mantidas sob condições ambientais.

Os alimentos são desperdiçados quando, em boas condições físicas, não são aproveitados para consumo, destacando-se as sobras de refeições nos pratos em domicílios e restaurantes, o não aproveitamento integral de frutos, raízes e folhas, o descarte dos produtos in natura com boas condições fisiológicas, em razão de prazo de validade expirado e, até mesmo pela falta de outras alternativas de aproveitamento. Por outro lado, ainda existem os fatores relacionados à depreciação da qualidade dos produtos, devido à deterioração, causada por amassamentos, cortes e podridões (VILELA et al., 2003). A política de doação de alimentos no Brasil não é incentivada, fato que poderia ser mudado com o projeto Lei 4747/1998, que incentiva a doação de alimentos para instituições cadastradas, protegendo o doador dos alimentos de responsabilidades legais, caso o produto tenha 
sido doado de boa fé e venha a causar danos à saúde do beneficiado (SCHVEITZER et al., 2016).

Segundo AGNES et al. (2018), cascas, talos e sementes provenientes de resíduos de frutas e hortaliças podem ser empregados como ingredientes de produtos já existentes ou no desenvolvimento de novos produtos. As folhas da cenoura, por exemplo, são pouco utilizadas na alimentação habitual, porém as mesmas podem ser uma boa fonte de fibras, vitamina $B 1$, vitamina $B 2$, vitamina $B 6$, vitamina $C$, vitamina $\mathrm{K}$, biotina, potássio e tiamina (JUNIOR \& OLIVEIRA, 2013).

A utilização das farinhas mistas pode ser direcionada para a melhoria da qualidade sensorial e nutricional de produtos alimentícios, visando benefícios à saúde do consumidor, bem como o desenvolvimento de produtos alimentícios com emprego total de hortaliças e sua inclusão na elaboração de produtos industrializados possibilitando a disponibilidade de nutrientes (proteínas, fibras, vitaminas e minerais) (AGNES et al., 2018).

Amorim (2014) também afirma que utilizar subprodutos ou resíduos de vegetais e frutas como matéria-prima pode ser uma excelente opção para o enriquecimento nutricional de novos produtos, além de serem responsáveis pelo melhor funcionamento do organismo e atuarem na prevenção de diversas patologias.

Neste sentido, considerando os benefícios do reaproveitamento dos alimentos, objetivou-se analisar nutricionalmente e sensorialmente pães e massas, elaborados com substituição parcial da farinha de trigo por farinha de cenoura, contribuindo com a redução do desperdício deste vegetal.

\section{METODOLOGIA}

\section{1- Elaboração da farinha de cenoura}

As cenouras in natura empregadas foram, inicialmente, lavadas em água corrente e selecionadas, descartando-se as partes que apresentavam algum dano visual. Após, passaram por um processo de higienização, em água corrente e, com o auxílio de escova de limpeza e faca, foram removidas sujidades, partes danificadas e as pontas. Em seguida, foram colocadas em imersão em uma solução de hipoclorito de sódio $150 \mathrm{mg} \mathrm{L}^{-1}$, por 15 minutos, para completa sanitização, lavadas novamente com água corrente e processadas com casca, em multiprocessador Philips Walita ${ }^{\circledR}$.

Para o processo de secagem, utilizou-se desidratadora com controle de temperatura Marconi ${ }^{\circledR}$, com circulação de ar à temperatura de $45^{\circ} \mathrm{C}$ por $9 \mathrm{~h}$. Para secagem mais efetiva, a cenoura ralada foi disposta de forma espalhada sobre uma rede de nylon. Após a secagem, as cenouras foram analisadas quanto ao teor percentual de umidade, através da balança de umidade OHAUS $®$, trituradas em moinho de facas Solab® e a farinha obtida foi acondicionada em embalagens herméticas e protegidas da ação da luz.

\section{2- Produção de pães e massas frescas}

Para a elaboração dos pães e da massa fresca, utilizouse a farinha de cenoura (FC) obtida após o processo de secagem e foram elaborados pães tipo bisnaguinha e massa fresca tipo macarrão, com substituições percentuais de 10, 15 e $20 \%$ da farinha de trigo (FT) por FC. A proporção de substituição foi definida a partir de ensaios prévios de formulações, sendo que percentuais superiores a $20 \%$ levaram a produtos com textura quebradiça. A Tabela 1 apresenta a formulação dos pães e a Tabela 2, a formulação das massas frescas.

Tabela 1 - Formulações dos pães

\begin{tabular}{ccccc}
\hline Ingredientes & Padrão & $\mathbf{1 0 \%}$ FC & $\mathbf{1 5 \%}$ FC & $\mathbf{2 0 \%}$ FC \\
\hline $\begin{array}{c}\text { Farinha de } \\
\text { trigo (g) }\end{array}$ & 500 & 450 & 425 & 400 \\
Farinha de & - & 50 & 75 & 100 \\
cenoura (g) & & & & \\
Fermento & 10 & 10 & 10 & 10 \\
biológico (g) & 10 & 10 & 10 & 10 \\
Açúcar (g) & 5 & 5 & 5 & 5 \\
$\quad$ Sal (g) & 300 & 300 & 300 & 300 \\
Água morna & & 50 & 50 & 50 \\
$\quad$ (mL) & 50 & 2 & 2 & 2 \\
Margarina (g) & 50 & & \\
Ovos (un.) & 2 & 2018 &
\end{tabular}

Fonte: Autores, 2018.

Para a produção dos pães tipo bisnaguinha, os ingredientes foram pesados em balança semi-analítica e misturou-se a água morna, fermento, ovo, açúcar, leite, sal, farinha de cenoura e o óleo, sequencialmente. Homogeneizou-se, adicionou-se a farinha de trigo e, em seguida, a massa foi sovada e deixada para descansar em um recipiente coberto, durante $60 \mathrm{~min}$. A massa foi dividida em partes pequenas e os pães foram moldados em formato de bisnaguinha. Após repouso por $20 \mathrm{~min}$, foram distribuídos em forma untada e levados ao forno pré-aquecido à temperatura de $190^{\circ} \mathrm{C}$ por $30 \mathrm{~min}$.

Tabela 2 - Formulações das massas frescas

\begin{tabular}{ccccc}
\hline Ingredientes & Padrão & $\mathbf{1 0 \%}$ FC & $\mathbf{1 5 \%}$ FC & $\mathbf{2 0 \%}$ FC \\
\hline $\begin{array}{c}\text { Farinha de } \\
\text { trigo }(\mathrm{g})\end{array}$ & 250 & 225 & 212,5 & 200 \\
$\begin{array}{c}\text { Farinha de } \\
\text { cenoura }(\mathrm{g})\end{array}$ & - & 25 & 37,5 & 50 \\
$\quad$ Sal $(\mathrm{g})$ & 3 & 3 & 3 & 3 \\
$\begin{array}{c}\text { Óleo de soja } \\
\text { (mL) }\end{array}$ & 20 & 20 & 20 & 20 \\
Ovos (um.) & 3 & 3 & 3 & 3 \\
\hline
\end{tabular}

Fonte: Autores, 2018.

Para a produção das massas frescas, foram seguidos os seguintes procedimentos: pesar os ingredientes em balança semi-analítica, misturar e homogeneizar os ovos, óleo, sal e a farinha de cenoura para então adicionar a farinha de trigo, sovar, laminar e cortar a massa e, por fim, secar a massa fresca à temperatura ambiente por $30 \mathrm{~min}$, acomodada em embalagens plásticas.

\section{3-Composição centesimal}

A determinação da composição centesimal foi realizada, em triplicata, para cada uma das amostras obtidas das diferentes formulações, tanto para os pães tipo bisnaguinha quanto para as massas frescas tipo macarrão e também para a farinha de cenoura.

Determinaram-se, segundo as metodologias descritas pelo Instituto Adolfo Lutz (IAL, 2008), os teores percentuais de umidade, com secagem em estufa à $105^{\circ} \mathrm{C}$ até peso constante; cinzas por incineração em mufla $\left(550-600^{\circ} \mathrm{C}\right)$, até peso constante; fibra bruta, pelo método de Weender; lipídios, pelo método de Soxhlet e proteínas por meio da determinação do teor de nitrogênio total e conversão em proteína bruta pelo fator 6,25 (método Kjeldahl). O teor de carboidratos foi determinado por diferença e o valor calórico 
foi calculado considerando que, em média, $1 \mathrm{~g}$ de proteína fornece 4 calorias (4 Kcal), $1 \mathrm{~g}$ de gordura fornece 9 calorias ( $9 \mathrm{Kcal})$ e $1 \mathrm{~g}$ de carboidratos fornece 4 calorias $(4 \mathrm{Kcal})$ segundo a regulamentação da ANVISA RDC no 360, de 23 de dezembro de 2003.

\section{4 - Análise sensorial}

Os produtos elaborados (pães tipo bisnaguinha e massas frescas) com os diferentes percentuais de farinha de cenoura foram avaliados no primeiro dia após a elaboração dos mesmos, nos turnos tarde e noite, por 66 provadores não treinados, de ambos os sexos, da comunidade acadêmica da Universidade de Santa Cruz do Sul/RS, no Laboratório de Tecnologia de Alimentos. As amostras foram codificadas com letras e números (ANJOS et al., 2017), conforme apresentado na Tabela 3 .

Tabela 3 - Códigos das amostras para análise sensorial

\begin{tabular}{cc}
\hline Código & Produto elaborado \\
\hline BC301 & Pão bisnaguinha - 10\% FC \\
BC305 & Pão bisnaguinha - 15\% FC \\
BC302 & Pão bisnaguinha - 20\% FC \\
MF141 & Massa fresca - 10\% FC \\
MF145 & Massa fresca - 15\% FC \\
MF142 & Massa fresca - 20\% FC \\
\hline
\end{tabular}

Cada provador pode avaliar as amostras quanto à preferência e aceitação segundo Minim (2010). A análise de aceitação foi realizada com base nas características organolépticas dos pães e das massas como cor, aroma, sabor, textura e aparência.

Os pães e as massas frescas foram elaborados seguindo as normas de boas práticas na fabricação de alimentos e, servidos, durante a análise sensorial, à temperatura ambiente, em porções individuais em pratos plásticos descartáveis. Entre o intervalo de cada amostra o avaliador recebeu água para enxágue da boca.

A pesquisa de análise sensorial foi aprovada pelo Comitê de Ética em Pesquisa (CEP) da universidade sob número CAAE 57129816.2.0000.5343.

\section{5 - Análise estatística}

A análise estatística foi realizada com os resultados da composição centesimal dos produtos elaborados, pães tipo bisnaguinha e massa fresca tipo macarrão, através do teste de Tukey para verificação da existência de diferenças estatísticas entre as médias no nível de $1 \%$ e $5 \%$ de significância, utilizando o Software Statistic ${ }^{\circledR}$ versão 12.0.

\section{RESULTADOS}

\section{1- Tempo de secagem para elaboração da farinha de} cenoura

Com base no emprego da temperatura de $45^{\circ} \mathrm{C}$ por $9 \mathrm{~h}$, obtiveram-se produções de farinha de cenoura com percentuais de umidade de $12 \%$ (primeiro lote) e 9,4\% (segundo lote), atendendo à regulamentação da ANVISA RCD n ${ }^{\circ} 263$, de 22 de setembro de 2005, na qual o percentual de umidade máximo para a farinha de cenoura é de $15 \%$. Álvares et al. (2013), afirmam que níveis de umidade superiores a $13 \%$ podem favorecer o crescimento microbiano e deterioração em curto tempo.
Os percentuais de umidade obtidos para a farinha de cenoura são mais elevados que os teores encontrados por Rohlfes et al. (2017), que foram de 5,35\% para a farinha da casca da cenoura e de $6,02 \%$ para a farinha da polpa da cenoura.

\section{2 - Composição centesimal}

\subsection{1 - Composição centesimal dos pães tipo bisnaguinhas}

São apresentados, na Tabela 4, os resultados da determinação da composição centesimal dos pães elaborados com os diferentes percentuais de farinha de cenoura em substituição à farinha de trigo. As amostras receberam as seguintes codificações: PB10 (pão bisnaguinha com 10\% FC), PB15 (pão bisnaguinha com 15\% FC) e PB20 (pão bisnaguinha com $20 \%$ FC).

Tabela 4- Composição centesimal $\left({\left.\mathrm{g} 100 \mathrm{~g}^{-1}\right) \text { dos pães }}^{2}\right.$

\begin{tabular}{cccc}
\hline PARÂMETRO & PB10 & PB15 & PB20 \\
\hline Umidade & $28,16^{\mathrm{c}} \pm 0,04$ & $34,93^{\mathrm{b}} \pm 0,25$ & $39,87^{\mathrm{a}} \pm 0,16$ \\
Cinzas & $1,58^{\mathrm{b}} \pm 0,42$ & $1,50^{\mathrm{b}} \pm 0,23$ & $2,41^{\mathrm{a}} \pm 0,20$ \\
Fibras & $0,94^{\mathrm{b}} \pm 0,11$ & $1,30^{\mathrm{b}} \pm 0,10$ & $2,70^{\mathrm{a}} \pm 0,43$ \\
Lipídios & $5,07^{\mathrm{a}} \pm 0,05$ & $2,60^{\mathrm{b}} \pm 0,56$ & $2,59^{\mathrm{b}} \pm 0,03$ \\
Proteínas & $11,13^{\mathrm{a}} \pm 0,01$ & $9,42^{\mathrm{b}} \pm 0,04$ & $8,64^{\mathrm{c}} \pm 0,09$ \\
Carboidratos & $53,12^{\mathrm{a}}$ & $50,26^{\mathrm{b}}$ & $44,68^{\mathrm{c}}$ \\
Valor calórico & $302,63^{\mathrm{a}}$ & $262,12^{\mathrm{b}}$ & $236,59^{\mathrm{c}}$ \\
(Kcal) & & &
\end{tabular}

Desvio padrão para $n=3$

a,b,c Letras iguais na mesma linha indicam não haver diferença estatística significativa de acordo com o teste de Tukey a 5\% de probabilidade. Fonte: Autores, 2018.

A análise estatística aplicada demonstrou que há diferença significativa $(p>0,05)$ entre as formulações de pães elaboradas com os diferentes percentuais de farinha de cenoura, em relação à umidade. Apenas a amostra PB20 apresentou valores que não se enquadram no limite definido pela RDC n ${ }^{\circ} 90$, de 18 de outubro de 2000 que estabelece teor máximo de 38\% (BRASIL, 2000). Silva et al. (2014) afirmam que a presença de umidade influencia a qualidade, estabilidade e composição dos alimentos, proporcionando alterações nas estruturas, aspecto e sabor dos mesmos.

Quanto aos teores percentuais de cinzas, observa-se um incremento proporcional à substituição de farinha de trigo. Comportamento semelhante foi encontrado por Agnes et al. (2018) e Soares et al. (2017) na elaboração de pães com substituição parcial de farinha de trigo por farinha de beterraba e de resíduos de goiaba, respectivamente.

Da mesma forma, observou-se incremento nos teores percentuais de fibras, proporcionalmente à substituição de farinha de trigo. As substituições realizadas não levaram à obtenção de produtos alimentícios classificados como rica

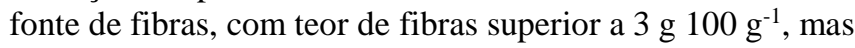
a amostra PB20 apresentou um teor dentro do mínimo

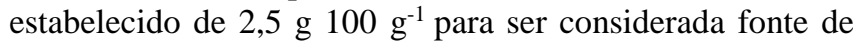
fibras (BRASIL, 1998).

Por sua vez, ocorreu diminuição dos percentuais de proteínas e lipídios, proporcional à substituição da farinha de trigo. Em relação ao teor de lipídios, as formulações apresentaram uma redução de $48,9 \%$ em relação ao percentual de substituição. Os teores percentuais de proteínas tiveram redução significativa entre as formulações, sendo de $15,4 \%$ entre PB10 e PB15, e de 8,3\% entre PB15 e PB20. 
A diminuição de $15,9 \%$ dos teores de carboidratos foi proporcional ao percentual de substituição da farinha de trigo, bem como para os valores calóricos encontrados. As bisnaguinhas elaboradas possuem 7,3\% de calorias a menos, quando comparadas com os valores encontrados por Tavares et al. (2017), que obtiveram média de $288,1 \mathrm{Kcal} 100 \mathrm{~g}^{-1}$.

\subsection{2 - Composição centesimal das massas frescas tipo macarrão}

São apresentados, na Tabela 5, os resultados encontrados na determinação da composição centesimal das massas frescas elaboradas com os diferentes percentuais de farinha de cenoura em substituição à farinha de trigo. As amostras receberam as seguintes codificações: MF10 (massa fresca tipo macarrão com 10\% FC), MF15 (massa fresca tipo macarrão com $15 \%$ FC) e MF20 (massa fresca tipo macarrão com $20 \%$ FC).

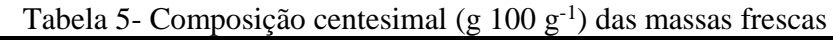

\begin{tabular}{cccc}
\hline PARÂMETRO & MF10 & MF15 & MF20 \\
\hline Umidade & $30,83^{\mathrm{a}} \pm 0,14$ & $30,08^{\mathrm{a}} \pm 0,43$ & $31,58^{\mathrm{a}} \pm 0,28$ \\
Cinzas & $1,62^{\mathrm{c}} \pm 0,11$ & $2,17^{\mathrm{a}} \pm 0,08$ & $1,97^{\mathrm{b}} \pm 0,49$ \\
Fibras & $0,40^{\mathrm{c}} \pm 0,10$ & $0,84^{\mathrm{b}} \pm 0,40$ & $1,17^{\mathrm{a}} \pm 0,15$ \\
Lipídios & $1,47^{\mathrm{c}} \pm 0,74$ & $4,22^{\mathrm{a}} \pm 0,94$ & $3,00^{\mathrm{b}} \pm 1,07$ \\
Proteínas & $11,99^{\mathrm{a}} \pm 0,05$ & $11,94^{\mathrm{a}} \pm 0,04$ & $11,71^{\mathrm{a}} \pm 0,04$ \\
Carboidratos & $53,69^{\mathrm{a}}$ & $50,76^{\mathrm{b}}$ & $50,89^{\mathrm{b}}$ \\
Valor calórico & $275,95^{\mathrm{b}}$ & $288,78^{\mathrm{a}}$ & $277,40^{\mathrm{b}}$ \\
(Kcal) & & &
\end{tabular}

Desvio padrão para $n=3$

${ }^{a, b, c}$ Letras iguais na mesma linha indicam não haver diferença estatística significativa de acordo com o teste de Tukey a $5 \%$ de probabilidade. Fonte: Autores, 2018.

Os valores obtidos na determinação do percentual de umidade de todas as amostras de massas frescas analisadas atenderam à legislação, que preconiza um teor máximo de $35 \%$ de umidade. Ainda, os teores de proteínas foram superiores ao mínimo de $8 \%$, ambos predeterminados pela RDC N $\mathrm{N}^{\circ}$ 93, de 31 de outubro de 2000, que rege os padrões de identidade e qualidade de massa alimentícia (ANVISA, 2000).

Os teores de gordura são inferiores aos valores reportados por Nicoletti et al. (2007), na qual analisaram macarrão elaborado com subprodutos (farelo de soja integral, farinha de arroz e farinha de arroz pré-gelatinizada). Os autores encontraram teores percentuais de lipídios de 5,67\% para o macarrão padrão e de 5,55\% para o macarrão testado com os subprodutos.

Os teores percentuais de fibras determinados nas massas frescas, assim como os encontrados na análise dos pães, não permitem a classificação dos mesmos como um produto alimentício fonte de fibras, mas há um aumento de 92,5\% quanto aos percentuais de substituição de farinha de cenoura.

Os valores calóricos das amostras de massas frescas foram inferiores aos encontrados por Agnes et al. (2018) no estudo da substituição de farinha de trigo por diferentes percentuais de farinha de beterraba $(326,78 \mathrm{Kcal}, 314,67$ Kcal e 299,38 Kcal, para substituições de 10,15 e $20 \%$, respectivamente) e de Pereira et al. (2017) na análise de massa alimentícia fresca incorporada de farinha de coquinhoazedo (Butia capitata) que foi de 410,49 Kcal $100 \mathrm{~g}^{-1}$.

\section{3 - Análise sensorial}

As massas frescas e os pães tipo bisnaguinha foram preparados com $24 \mathrm{~h}$ de antecedência à analise sensorial e armazenados em recipientes plásticos. As massas foram cozidas durante a análise sensorial sem adição de sal e os pães foram fatiados e disponibilizados.

A Figura 1 apresenta, o gráfico dos resultados obtidos quanto ao teste de preferência dos pães tipo bisnaguinha (PB10, PB15 e PB20) e das massas frescas (MF10, MF15 e MF20) elaborados com diferentes percentuais de substituição da farinha de trigo por farinha de cenoura.

Figura 1 - Gráfico referente ao resultado percentual de preferência dos provadores

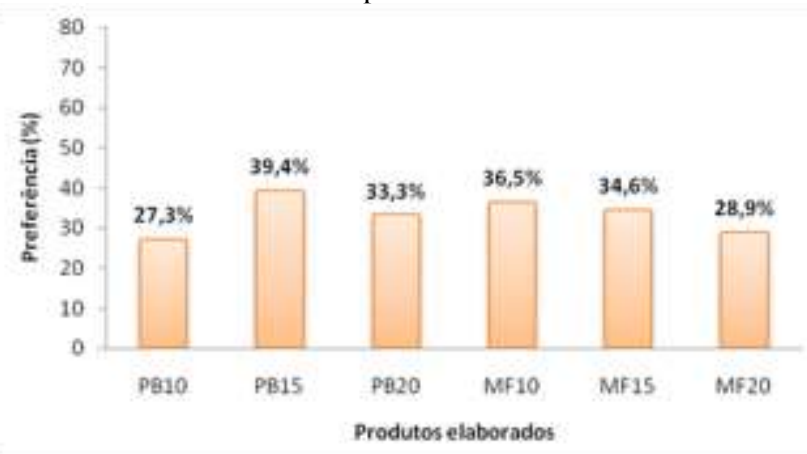

Fonte: Autores, 2018

Os 66 provadores não treinados manifestaram preferência pelo pão bisnaguinha com $15 \%$ de substituição da farinha de trigo, num percentual de $39,4 \%$ entre homens e mulheres e pela massa fresca com $10 \%$ de percentual de farinha de cenoura, com $36,5 \%$ de preferência por ambos os sexos.

Quanto à aceitação dos produtos elaborados, os provadores expressaram suas impressões quanto aos quesitos cor, aroma, sabor, textura e aceitação, utilizando escala hedônica de 9 pontos, com escores variando de 9 "gostei extremamente" a 1 "desgostei extremamente" (MINIM, 2010). O resultado desta análise para os pães pode ser observado no gráfico da Figura 2, ocorrendo maior percentual de aceitação nos quesitos aparência, cor e aroma. 37,8\% dos provadores gostaram muito da aparência dos pães tipo bisnaguinhas, 34,6\% gostaram muito do seu aroma e 35,7\% gostaram extremamente da cor.

Figura 2 - Gráfico referente ao percentual de aceitabilidade dos pães tipo bisnaguinhas

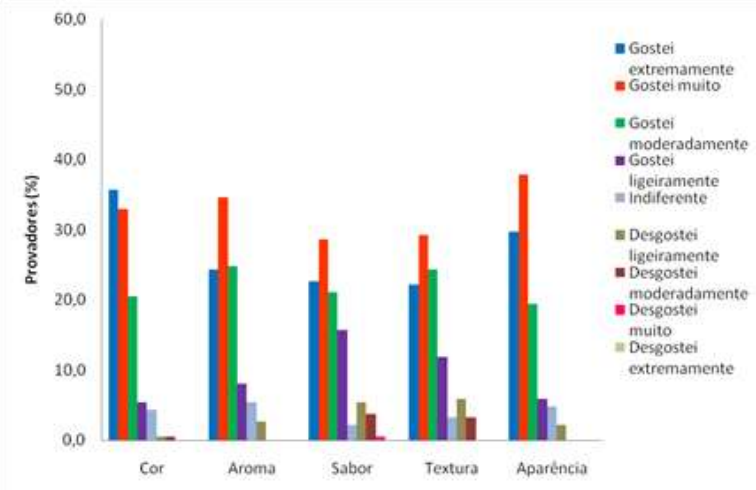

Fonte: Autores, 2018. 
A adição de $15 \%$ de farinha de cenoura na formulação provocou uma maior aceitação nos quesitos sabor e textura, onde os avaliadores se mantiveram na região dos quesitos "gostei extremamente" e "gostei muito" dessa formulação, que possuia um sabor bem caracteristico da cenoura e uma textura não tão seca (PB10) e nem tão pesada (PB20).

$\mathrm{Na}$ avaliação do gráfico (Figura 3), a aceitabilidade das massas frescas, demonstrou que os provadores gostaram muito da cor $(34 \%)$, sabor $(33,3 \%)$ e gostaram extremamente da aparência $(35,3 \%)$.

Figura 3 - Gráfico referente ao percentual de aceitabilidade das massas frescas

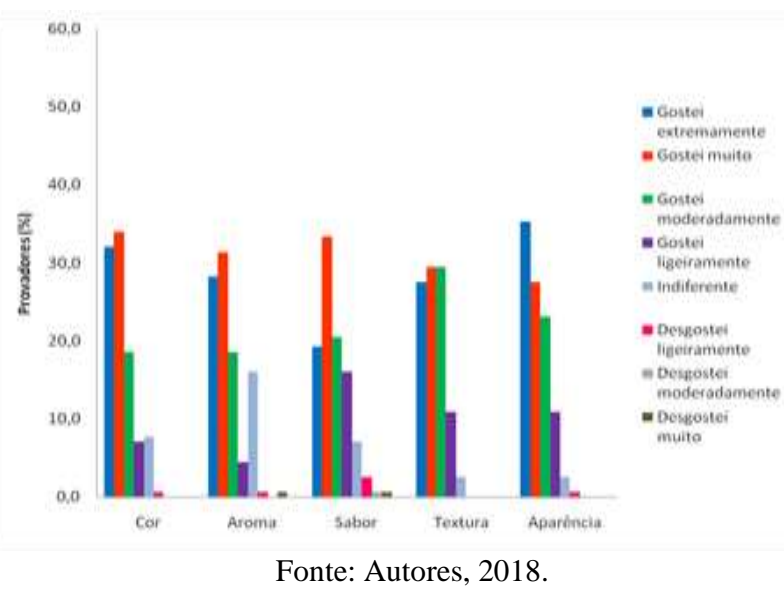

IV. CONCLUSÃO

A substituição da farinha de trigo por diferentes percentuais de farinha de cenoura demonstrou a viabilidade em elaborar produtos como pães bisnaguinhas e massas frescas. Apesar não terem os teores exigidos para serem considerados produtos alimentícios de alta fonte de fibras, as amostras apresentaram um valor proteico muito significativo, e teores de gorduras relativamente baixos quando comparados com os produtos convencionais disponibilizados para consumo e os elaborados em outros estudos com farinhas funcionais.

A análise sensorial demonstrou que as pessoas estão dispostas a consumir produtos alimentícios funcionais, e que as formulações propostas tanto para os pães bisnaguinhas quanto para as massas frescas, tiveram bons resultados de aceitação.

De forma geral, os produtos elaborados tiveram boa aceitação perante os provadores, com percentuais elevados nos diferentes quesitos, salientando-se a aparência e a cor. Ainda, diferentes formas de se apresentar um produto, podem ser alternativas para incorporar cada vez mais as farinhas funcionais no dia a dia da população.

\section{AGRADECIMENTOS}

À Secretaria da Ciência, Inovação e Desenvolvimento Tecnológico do estado do Rio Grande do Sul (SDECT/RS) pelo financiamento da pesquisa, realizada no Projeto "Uso de resíduos vegetais na produção de farinhas funcionais e bioativas", Convênio DCIT 75/2015, aos Laboratórios de Ensino do Curso de Química da Universidade de Santa Cruz do Sul e aos professores orientadores deste presente trabalho.

\section{REFERÊNCIAS}

AGNES, F. et al. Elaboração de massas frescas e pães com diferentes percentuais de farinha de beterraba (Beta vulgaris esculenta), em substituição à farinha de trigo. Revista SODEBRAS, v.13, n. 155, p. 51-56, nov., 2018.

ÁLVARES, V. S. et al. Atributos físicos e físico-químicos da farinha de mandioca artesanal em Rio Branco, Acre. Revista Caatinga, Mossoró, v. 26, n. 2, p. 50-58, abr.-jun., 2013.

AMORIM, E. G. Elaboração alternativa de produtos a partir de resíduos alimentares. Veredas Revista Eletrônica de Ciências, v. 7, n. 1, p.50-60, 2014

ANJOS, C. N. dos et al. Desenvolvimento e aceitação de pães sem glúten com farinhas de resíduos de abóbora (Cucurbita moschata). Arq. Ciênc. Saúde, v. 24, n. 4, p. 58-62, out-dez, 2017.

ANVISA. Agência Nacional de Vigilância Sanitária. Resolução RDC $\mathbf{n}^{\circ}$ 93, de 31 de outubro de 2000. Regulamento técnico para fixação de identidade e qualidade de massa alimentícia. Diário oficial da República Federativa do Brasil, Poder Executivo, Brasília-DF, 01 novembro 2000. Seção I.

ANVISA. Agência Nacional de Vigilância Sanitária. Resolução RDC no 263, de 22 de setembro de 2005 . Regulamento técnico para produtos de cereais, amidos, farinhas e farelos. Disponível em: $<$ http://portal.anvisa.gov.br/documents/33916/394219/RDC _263_2005.pdf/e9aa3580-f130-4eb5-91cb-8b8818bcf6b2> Acesso em 23 mai. 2018.

ANVISA. Agência Nacional de Vigilância Sanitária. Resolução RDC no 360, de 23 de dezembro de 2003. Regulamento técnico para rotulagem nutricional de alimentos embalados. Disponível em: http://portal.anvisa.gov.br/documents/33880/2568070/res03 60_23_12_2003.pdf/5d4fc713-9c66-4512-b3c1afee $57 \mathrm{e} 7 \mathrm{~d} 9 \mathrm{bc}>$ Acesso em 17 jun. 2018.

BRASIL. Ministério da Saúde. Agência Nacional de Vigilância Sanitária. Resolução RDC $\mathbf{n}^{\circ}$ 90, de 18 de outubro de 2000. Regulamento técnico para fixação de identidade e qualidade de pão. Disponível em: <http://www.anvisa.gov.br/anvisalegis/resol/2000/90_00rdc. htm>. Acesso em 23 mai. 2018.

BRASIL. Ministério da Saúde, Agência Nacional de Vigilância Sanitária. Portaria no 27, de 13 de janeiro de 1998. Regulamento técnico referente à informação nutricional complementar (declarações relacionadas ao conteúdo de nutrientes). Diário Oficial da União, de 16 de janeiro de 1998. Disponível em: < http://portal.anvisa.gov.br/documents/33916/394219/PORT ARIA_27_1998.pdf/72db7422-ee47-4527-9071859f1f7a5f29>. Acesso em 17 jun. 2018

CORRÊA, I. M. et al. Farinha de cenoura em estágio de maturação avançada como alternativa à redução do desperdício de alimentos. Multi-Science Journal, v. 1, n. 10, p. 61-68, 2018.

INSTITUTO ADOLFO LUTZ. Normas Analíticas do Instituto Adolfo Lutz. Métodos físico-químicos para análises de alimentos. $4^{\mathrm{a}}$ ed. (1 ${ }^{\mathrm{a}}$ Edição digital), 2008. 1020 p. 
JUNIOR, O. M. C.; OLIVEIRA, A. P. Caracterização físicoquímica da farinha da folha de cenoura (Daucus carota) e a aplicação na elaboração de produtos alimentícios. Revista Brasileira de Tecnologia Agroindustrial, v. 07; n.02; 2013

MINIM, Valéria Paula Rodrigues. Análise sensorial: estudos com consumidores. 2. ed. Viçosa: Ed. UFV, 2010. 308 p.

NICOLETTI, A. M. et al. Uso de subprodutos agroindustriais no desenvolvimento de macarrão nutricionalmente melhorado. ALIM. NUTRI. Araraquara. v.18, n.4, p.421429, out/dez. 2007.

PEREIRA, F. et al. Desenvolvimento de farinha de folhas de cenoura e aplicação na elaboração de produto alimentício. RIES, Caçador, v.3, n.2, p. 145-154, 2014

PEREIRA, G. S. L. et al. Análises físico-químicas e tecnológicas em massa alimentícia fresca incorporada de farinha de coquinho-azedo (Butia capitata). Cad. Ciênc. Agrá., v. 9, n. 3, supl. 1, p. 01-05, 2017.

RESENDE, G. M. et al. Desempenho de cultivares de cenoura em sistema orgânico de cultivo em condições de temperaturas elevadas. Hortic. Bras., Vitória da Conquista, v. 34, n. 1, p. 121-125, Mar. 2016. Available from $<$ http://www.scielo.br/scielo.php?script=sci_arttext\&pid=S0 102-05362016000100121\&lng=en\&nrm=iso >. access on 26 Nov. 2018. http://dx.doi.org/10.1590/S0102053620160000100018 .

ROHLFES, A. L. B. et al. Caracterização de pães elaborados com substituição parcial de farinha de trigo por farinha funcional de cenoura (Daucus carota). Revista Sodebras [online]. v. 12, n. 134, fev/2017, p. 127-132. ISSN 18093957.

Disponível em: $\langle$ http://www.sodebras.com.br/edicoes/N134.pdf $>$.

Acesso em 23 mai. 2018.

SANTOS, A-K. et al. Caracterização física e química de biscoito salgado enriquecido com farinha de resíduos do processamento da cenoura e especiarias. R. Bras. Tecnol. Agroindustr., Ponta Grossa, v. 11, n. 02: p. 2368-2381, jul./dez. 2017. DOI: 10.3895/rbta.v11n2.3062

SCHVEITZER, B. et al. Caracterização química das farinhas de hortaliças e de descarte agrícolas. Revista da Jornada de Pós-Graduação e Pesquisa. Vol.13, 2016, p.4. ISSN 1982 2960. Disponivel em trabalhos.congrega.urcamp.edu.br/index.php/jpgp/article/do wnload/1020/993.

SILVA, J. P. et al. Avaliação físico-química e sensorial de pães produzidos com substituição parcial de farinha de trigo por farinha de banana verde. Revista Brasileira de Pesquisa em Alimentos, v. 5, n. 3, p. 1-7, 2014.

SILVA, A. C. B. et al. Qualidade nutricional e físico-química em cenoura (Daucus carota L.) in natura e minimamente processada. DEMETRA: alimentação, nutrição \& saúde, v.11, n. 2, p. 355-367, 2016.

SOARES, D. J. et al. Utilização de farinha de resíduos de goiaba na elaboração de pães. Revista CIENTEC. Vol. 9, n. 1, 97-103, 2017.

TAVARES, J. S. et al. Composição nutricional de pães do tipo bisnaguinha e comparação com a legislação de rotulagem nutricional. Revista visa em debate - sociedade, ciência \& tecnologia, v. 5, n. 1, p. 45-51, 2017.

VILELA, N. J. et al. O peso da perda de alimentos para a sociedade: o caso das hortaliças. HORTIC. BRAS. v.21, n. 2, p. 142-144, abr/jun 2003.

\section{COPYRIGHT}

Direitos autorais: Os autores são os únicos responsáveis pelo material incluído no artigo.

Submetido em: $28 / 11 / 2018$

Aprovado em: 07/12/2018 


\section{Área: Ciências Exatas e Engenharias}

\begin{tabular}{|c|c|}
\hline $1-3$ & $\begin{array}{l}\text { ANÁLISE DA RELAÇÃO DA CULTURA MAKER, FABLABS E ROBÓTICA } \\
\text { EDUCACIONAL NA EDUCAÇÃO } \\
\text { ANALYSIS OF THE RELATIONSHIP OF CULTURE MAKER, FABLABS AND } \\
\text { EDUCATIONAL ROBOTICS IN EDUCATION } \\
\text { Peterson Albuquerque Lobato; Isabella Sampaio Santos; Camila Silva Pereira } \\
\text { Jorge; Matheus Guimarães Tanure; Eduardo Manoel De Freitas Jorge; Hugo } \\
\text { Saba; André Ricardo Magalhães }\end{array}$ \\
\hline $1-6$ & $\begin{array}{l}\text { OBTENÇÃO, CARACTERIZAÇÃO E AVALIAÇÃO DA ATIVIDADE } \\
\text { ANTIMICROBIANA DE FILME POLIMÉRICO DE GELATINA EXTRAÍDA } \\
\text { DAS ESCAMAS DE TILÁPIA CONTENDO COMO CARGA O SALICILATO } \\
\text { DE COBALTO(II) } \\
\text { OBTAINING, CHARACTERIZATION AND THE ANTIMICROBIAL EVALUATION } \\
\text { OF THE POLYMERIC FILM OF GELATIN EXTRACTED FROM THE TILAPIA } \\
\text { SCALES CONTAINING COBALT(II) SALICYLATE AS LOAD } \\
\text { Kauani Caldato; Filipe Kialil Da Silva Neves; Gabrielle Cristina Calegari; Vidiany } \\
\text { Aparecida Queiroz Santos; Mario Antônio Alves Da Cunha; Leandro Zatta }\end{array}$ \\
\hline $3-3$ & $\begin{array}{l}\text { DESENVOLVIMENTO DE UM SISTEMA AUTOMATIZADO PARA ALIMENTAÇÃO } \\
\text { DE LINHAS DE PRODUÇÃO DE RÁDIOS AUTOMOTIVOS INTRÍNSECO A } \\
\text { INDUSTRIA 4.0 } \\
\text { DEVELOPMENT OF AN AUTOMATED SYSTEM FOR POWER SUPPLY OF } \\
\text { AUTOMATIC RADIO PRODUCTION INTRINSIC TO INDUSTRY 4.0 } \\
\text { Erik Tavares Guedes; Manoel S. S. Azevedo; Jandecy Cabral Leite; Arlindo } \\
\text { Messias Mendes Da Costa; Geanne Tereza Ferreira Olimpio; Will Ribamar Mendes } \\
\text { Almeida }\end{array}$ \\
\hline $3-4$ & $\begin{array}{l}\text { VIABILIDADE DE APLICAÇÃO DE ENERGIA SOLAR PARA GERAÇÃO DE } \\
\text { ENERGIA E AQUECIMENTO DE ÁGUA } \\
\text { FEASIBILITY APPLICATION OF SOLAR ENERGY FOR POWER GENERATION } \\
\text { AND WATER HEATING } \\
\text { Fernando Da Costa Lima; Teofilo Miguel De Souza; Stephanie Caroline Machado } \\
\text { Thomaz Da Silva Lima; Pedro Magalhães Sobrinho }\end{array}$ \\
\hline $3-4$ & $\begin{array}{l}\text { DESENVOLVIMENTO DE UM PROGRAMA PARA } \\
\text { PARÂMETROS LONGITUDINAIS E TRANSVERSAIS DE LINHAS }\end{array}$ \\
\hline
\end{tabular}




\begin{tabular}{|c|c|}
\hline 3-4 & $\begin{array}{l}\text { MEDIDAS PARA REDUZIR O CONSUMO DE ENERGIA NO SETOR } \\
\text { RESIDENCIAL - UMA REVISÃO } \\
\text { MEASURES FOR REDUCING ENERGY CONSUMPTION IN THE RESIDENTIAL } \\
\text { SECTOR - A REVIEW } \\
\text { Thamyres Machado David; Teófilo Miguel De Souza; Paloma Maria Silva Rocha } \\
\text { Rizol; Marcela Aparecida Guerreiro Machado; Luciano Lizardo De Souza Guimarães }\end{array}$ \\
\hline 3-5 & $\begin{array}{l}\text { PRODUÇÃO DE SYNGAS E SEU USO NA GERAÇÃO DE ENERGIA: UMA } \\
\text { REVISÃO } \\
\text { SYNGAS PRODUCTION AND ITS POWER GENERATION USE: A REVIEW } \\
\text { Diogo Theodoro Lago; Teófilo Miguel De Souza; Luiz Carlos Bevilaqua Dos } \\
\text { Santos Reis; João Andrade De Carvalho Júnior }\end{array}$ \\
\hline 3-5 & $\begin{array}{l}\text { INFLUÊNCIA DA RELAÇÃO DE PRESSÃO E FRAÇÃO DE AR EXTRAÍDA } \\
\text { DO COMPRESSOR NO ARREFECIMENTO DAS PÁS DE TURBINAS A GÁS } \\
\text { INFLUENCE OF THE PRESSURE RATIO AND AIR FRACTION EXTRACTED } \\
\text { FROM THE COMPRESSOR ON GAS TURBINE BLADES COOLING } \\
\text { Crystiara Paula Santos Da Silva Venâncio; Larissa Rodrigues Marconi; Filipe Arthur } \\
\text { Firmino Monhol }\end{array}$ \\
\hline 3-8 & $\begin{array}{l}\text { ANTROPOMETRIA E ERGONOMIA COMO FERRAMENTAS DE VANGUARDA } \\
\text { PRODUTIVAS NAS INDÚSTRIAS DO FUTURO } \\
\text { ERGONOMICS AND ANTHROPOMETRY AS PRODUCTION VANGUARD TOOLS } \\
\text { IN THE INDUSTRIES OF THE FUTURE } \\
\text { Natasha Martins Rodrigues De Jesus; Rafael Soares Souza; Roque Antônio Moura }\end{array}$ \\
\hline
\end{tabular}




\title{
Revista SODEBRAS - Volume 14 $\mathrm{N}^{\circ} 157$ - JANEIRO/ 2019
}

\section{ANÁLISE DA RELAÇÃO DA CULTURA MAKER, FABLABS E ROBÓTICA EDUCACIONAL NA EDUCAÇÃO}

\author{
ANALYSIS OF THE RELATIONSHIP OF CULTURE MAKER, FABLABS AND \\ EDUCATIONAL ROBOTICS IN EDUCATION
}

\author{
PETERSON ALBUQUERQUE LOBATO ${ }^{1}$; ISABELLA SAMPAIO SANTOS ${ }^{2}$; CAMILA SILVA PEREIRA \\ JORGE $^{1}$, MATHEUS GUIMARÃES TANURE ${ }^{1}$, EDUARDO MANOEL DE FREITAS JORGE ${ }^{1}$, HUGO $^{2}$ \\ SABA $^{1}$, ANDRÉ RICARDO MAGALHÃES ${ }^{1}$ \\ 1 - UNIVERSIDADE DO ESTADO DA BAHIA, UNEB, SALVADOR, BAHIA; 2 - UNIVERSIDADE \\ FEDERAL DA BAHIA \\ peterson.lobato@gmail.com, isabellassampaio@gmail.com,camilaspjorge@gmail.com, \\ tanure.matheus@gmail.com,emjorge1974@gmail.com,hugosaba@gmail.com,andrerm@gmail.com
}

\begin{abstract}
Resumo - Está acontecendo uma revolução através do Movimento Maker, onde várias pessoas conectadas, trabalhando colaborativamente, são protagonistas dessa nova onda. Neste sentido, apoiando o Movimento Maker, laboratórios de Fabricação Digital, estão sendo criados em diversos países, como exemplo dos FabLabs equipados com impressoras $3 D$ e que desenvolvem projetos de robótica. Na educação esse movimento tem um papel importante na implementação de novos métodos educacionais. Este artigo desvela esses temas e apresenta uma pesquisa documental com base no portal de periódicos da CAPES, buscando a correlação destes temas com a educação. Como resultado da análise, observou-se que no Brasil há uma crescente implantação de FabLabs, contudo apesar desta tendência ainda existem poucas ações que utilizam a robótica aliada a impressão 3D com finalidade educacional.
\end{abstract}

Palavras-chave: Cultura Maker. FabLab. Impressão $3 D$. Robótica Educacional.

\begin{abstract}
A revolution is happening through the Maker Movement, where several people connected, working collaboratively, are protagonists of this new wave. In this sense, supporting the Maker movement, Digital Fabrication laboratories are being created in several countries, such as FabLabs, which is equipped with $3 D$ printers and enables the development of robotics projects. In education this movement plays an important role in the implementation of new educational methods. This article unveils these themes and presents a documentary research based on the CAPES journal portal, seeking the correlation of these themes with education. As a result of this analysis, it was observed that in Brazil there is a growing deployment of FabLabs, although in spite of this trend there are still few actions that use robotics allied to $3 D$ printing for educational purposes.
\end{abstract}

Keywords: Maker Culture. FabLab. 3D Printing. Educational Robotics.

\section{INTRODUÇÃO}

A revolução digital trouxe um impacto enorme na sociedade e agora está chegando às oficinas através de ferramentas de fabricação digital, como a impressora 3D, mudando a forma de como as coisas são produzidas e possibilitando que pessoas comuns possam empreender utilizando a criatividade como fator principal nesse processo.

Neste cenário, a Federação das Indústrias do Estado do Rio de Janeiro (FIRJAN), realizou o mapeamento da Indústria Criativa no Brasil no período de 2013 a 2016 dividindo os segmentos criativos em quatro áreas: Consumo (Design, Arquitetura, Moda e Publicidade), Mídias (Editorial e Audiovisual), Cultura (Patrimônio e Artes, Música, Artes Cênicas e Expressões Culturais) e Tecnologia (P\&D, Biotecnologia e TIC). Na produção, a área criativa gerou 155,6 bilhões de reais em 2016. A participação do PIB Criativo estimada no PIB Brasileiro cresceu de 2,56\% para 2,64\% entre 2013 e 2016. Isso demonstra que mesmo durante um cenário econômico complicado para o País, o setor criativo traz resultado significativo, aumentando também a participação de profissionais criativos no mercado de trabalho. As áreas de consumo e tecnologia absorveram mais de $80 \%$ desses profissionais, que têm médias salariais acima do dobro da média salarial do trabalhador formal (FIRJAN, 2016).

Um dos fatores que contribuem para este advento é a difusão de práticas profissionais mais autônomas, que colocam o indivíduo como protagonista na construção de sua carreira. Nesse contexto observa-se o crescimento do número de pessoas que usam o processo criativo para construir, consertar, modificar, criar e produzir objetos com as mãos, chamados de makers, presentes em vários segmentos da economia como os artesãos, costureiras, inventores em garagens, programadores, artistas, hobbistas, dentre outros.

No passado essas criações ficavam escondidas no local da criação. Com a conectividade da internet e a possibilidade de makers estarem conectados em âmbito global, houve crescimento na disseminação da cultura maker. Este movimento teve início na década de 90 e foi se fortalecendo na primeira década do século XXI pelas mídias digitais. Com conteúdos do tipo "Faça Você Mesmo" (do it yourself = DIY) ou "mão na massa" disponíveis para todos que possuem acesso à Internet. Isso encoraja muitos a entrarem nesse universo, formando grupos com interesses 
em comum que compartilham ideias, as quais somadas, podem aperfeiçoá-las (GAVASSA, 2016).

Pesquisas realizadas na área de educação demonstram que a capacidade de entender e resolver problemas pode ser estimulada por meio do ensino da computação e raciocínio lógico desde o ensino básico (SICA, 2011, apud REIS, 2017). Aliado a este fato percebe-se também que está em voga a temática do uso dos dispositivos eletrônicos na sala de aula, para ajudar no processo de aprendizagem. Contudo existe a dificuldade de acompanhar o ritmo acelerado de um mundo tecnológico e globalizado. No mercado de produtos educacionais diversos recursos estão disponíveis para utilização com os alunos, desde aplicativos (ex. jogos educativos digitais) até a robótica educacional. Mesmo com o suporte tecnológico inovador, muitas vezes este revela-se ineficaz para o aprendizado, por utilizar métodos inadequados ou antigos, caracterizados como herança da escola tradicional enraizada na mente da maioria dos educadores. É necessária uma discussão sobre novas formas de ensino e aprendizagem para elaborar novos métodos para a utilização dessas ferramentas.

Este artigo apresenta uma pesquisa documental com base no portal de periódicos da CAPES, buscando a correlação entre a Cultura Maker e seus Laboratórios de Fabricação Digital com a educação. É analisado, também, como o uso das impressoras 3D aliadas a componentes eletrônicos podem potencializar o ensino de robótica nas escolas.

É contextualizada na seção II deste trabalho o movimento que impulsionou a Cultura Maker, formado por pessoas criativas chamadas makers e os laboratórios de fabricação digital que as apoiam. Na seção III apresenta-se a utilização da impressora 3D e a sua importância na educação. A robótica educacional é retratada na seção IV com exemplos de aplicações na sala de aula. $\mathrm{Na}$ seção seguinte é discutida a metodologia utilizada para alcançar o objetivo deste trabalho. Na seção VI são divulgados os dados analisados, a discursão e os resultados obtidos. Por fim, a seção VII apresenta a conclusão deste trabalho.

\section{CULTURA MAKER}

No modelo industrial do século $\mathrm{XX}$, quem tinha o poder era quem controlava os meios de produção. Um pequeno inventor, dificilmente conseguiria colocar seu invento no mercado, pois não conseguia criar uma fábrica em sua casa. Para chegar ao mercado ele teria que convencer um fabricante e provavelmente perder grande parte dos direitos sobre a invenção. Empreender era difícil e poucos inventores tiveram sucesso. Os que conseguiram, ou já eram membros da classe dominante, ou aprenderam com ela (ANDERSON, 2012).

A Revolução Digital inicialmente foi associada à computação, e em seguida, à comunicação com o advento dos dispositivos móveis. Uma ideia e um computador, por intermédio da Internet, mesmo com pouco conhecimento técnico, um garoto pôde ganhar milhões, como o caso de Mark Zuckerberg do facebook. A distância que existia entre ser um inventor e um empreendedor foi tão encurtada que praticamente não existe mais. No mundo globalizado, um produto digital pode entrar facilmente em um mercado global de bilhões de pessoas (ANDERSON, 2012).

A próxima revolução será no campo da fabricação digital (GERSHENFELD, 2005 apud PINTO, 2016). Esta revolução já está acontecendo por meio do Movimento
Maker, onde várias pessoas conectadas, trabalhando colaborativamente, são protagonistas dessa nova onda.

Por ser livre, o Movimento Maker vem se fortalecendo e crescendo, disseminando suas ideias e filosofia, como pode ser observado através do Manifesto Maker lançado em 2004, que postula:

\begin{abstract}
"Faça - Fazer é a maior característica dos seres humanos. Nós temos que fazer, criar, e nos expressarmos, para nos sentirmos completos e felizes; Compartilhe - Compartilhando o que você faz e o que você aprendeu sobre o que fez é a forma pela qual esta satisfação de fazer é percebida; Presenteie - Há poucas coisas mais desprendidas e prazerosas do que presentear com coisas que você mesmo fez; Aprenda - Você deve aprender para fazer o melhor possível. Você deve sempre buscar aprender mais sobre os seus feitos; Equipe-se Você deve ter acesso às ferramentas adequadas para os seus projetos; Divirta-se - Divirta-se com o que você estiver fazendo, e você vai se surpreender, e se orgulhar com o que vai descobrir; Participe - Juntese ao Movimento Maker e espalhe para todos a sua volta, o prazer de fazer; Apoie - Este é um movimento que exige apoio emocional, intelectual, financeiro, político e institucional; Mude - Aceite as mudanças que naturalmente vão ocorrer enquanto você for avançando nesta missão; Permita-se errar - Seja tolerante com os seus erros, aprenda com eles e recomece (HATCH, 2014)."
\end{abstract}

Neste sentido, apoiando o Movimento Maker, laboratórios de Fabricação Digital, estão sendo criados em diversos países. Como exemplo, temos os FabLabs, os quais são espaços de prototipagem para inovação e invenção, fornecendo estímulos para o empreendedorismo local. Conectando-se a uma comunidade global de alunos, educadores, tecnólogos, pesquisadores, criadores e inovadores (FABLAB, 2018).

O primeiro FabLab, foi criado em 2001 nos Estados Unidos pelo Massachusetts Institute of Technology (MIT), fazendo parte do Center for Bits and Atoms (CBA), hoje, presente na maioria dos países do mundo (MIT - FABLAB, 2016, apud PINTO, 2016). Esses espaços são compostos basicamente por uma impressora $3 \mathrm{D}$, um cortador a laser que faz estruturas $2 \mathrm{D}$ e $3 \mathrm{D}$, uma fresadora $\mathrm{CNC}$ que fabrica placas de circuitos e peças de precisão e uma série de componentes eletrônicos e ferramentas de programação para microcontroladores de baixo custo para prototipagem de circuitos (FABLAB FOUNDATION, 2018). Nos FabLabs, os usuários aprendem projetando e criando objetos de interesse pessoal, obtendo conhecimento profundo sobre as máquinas, os materiais, o processo de design e a engenharia. Em contextos educacionais, o aprendizado acontece em uma experiência pessoal autêntica, envolvente, em que os alunos passam por um ciclo de imaginação, design, prototipagem, reflexão e interação, podendo encontrar soluções inovadoras para problemas do nosso cotidiano (FABLAB, 2018).

\section{IMPRESSÃO 3D NA EDUCAÇÃO}

No contexto dos FabLabs a Impressora 3D é um equipamento fundamental, graças a possiblidade de criação de protótipos ou mesmo produtos de forma rápida e com um custo reduzido. As impressoras 3D permitem que uma pessoa possa criar um objeto singular para o próprio uso. Não é preciso inventar algo original. Pode-se participar do aprimoramento colaborativo de projetos existentes 
(ANDERSON, 2012) ou se utilizar um Scanner 3D para gerar modelos $3 \mathrm{D}$, por meio da leitura digital de objetos físicos e até mesmo seres vivos (SOARES, et al, 2016). O acesso a esta tecnologia pode facilitar o surgimento de novas oportunidades de negócio para empreendedores, inventores, artesãos ou até mesmo uma pequena indústria, que com pouco recurso consiga lançar novos produtos.

$\mathrm{Na}$ educação, a impressão 3D pode ter um papel importante no desenvolvimento e implementação de novos métodos educacionais ou servindo como um meio de aprendizagem. O crescimento intelectual do aluno pode ocorrer baseado em sua experiência pessoal, e na produção personalizada de artefatos através do uso de uma impressora $3 \mathrm{D}$. Isso pode potencializar este crescimento motivando-os a expressar suas ideias (KOSTAKIS, NIAROS E GIOTITSAS, 2014 apud AGUIAR, 2016).

Para imprimir em 3D é necessário ter um desenho feito em três dimensões, que pode ser criado a partir de um software de modelagem 3D ou pode ser baixado em repositórios de modelos 3D disponíveis na Internet, como o Thingiverse criado pela Makerbot (THINGIVERSE, 2017). Neste portal encontra-se uma variedade de arquivos prontos para impressão, desde brinquedos, ferramentas, utensílios, até mesmo arquivos mais complexos como uma prótese de mão (Figura 1), ou até modelos para a construção de uma impressora 3D. Assim, os repositórios podem ser recursos fundamentais para a aplicação da impressão 3D, principalmente para quem não domine a modelagem 3D.

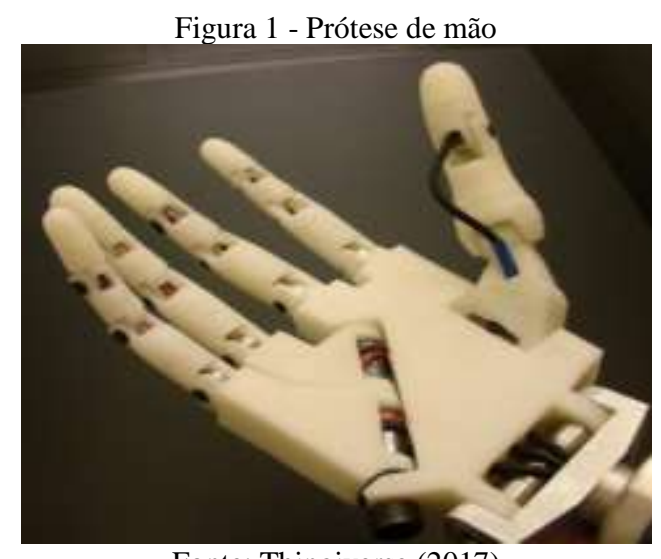

Fonte: Thingiverse (2017)

\section{ROBÓTICA EDUCACIONAL}

A Robótica Educacional (RE) permite levar para o mundo físico, o resultado do que foi desenvolvido no mundo virtual, por meio da programação (BORDINI, 2016). Ela tenta desvelar o que está escondido nas "caixas pretas" tecnológicas, desconstruindo conceitos para que se compreenda seu funcionamento. As pessoas, em seu dia a dia, não estão realmente atentas ao que estão fazendo. Elas "simplesmente estão trabalhando, falando, etc. mais ou menos cegas para a pervasividade das dimensões essenciais de comprometimento" (WINOGRAD, 1987, apud SILVA, 2012). Nesse contexto, a Robótica Educacional pode ajudar na compreensão desses artefatos tecnológicos. Através da robótica, o aprendiz utiliza artefatos físicos (placas, sensores, motores, engrenagens e diversos outros componentes eletrônicos) e artefatos lógicos (software para desenvolvimento de programas) para a construção do conhecimento (GOMES, 2010).
Segundo Bordine (2016), “os dispositivos robóticos respondem a estímulos (entradas), que são captadas por sensores; e respondem (saídas) por meio de atuadores (motores, rodas, engrenagens)". A captura das entradas e as saídas dos atuadores são realizadas por meio da programação. A Robótica Educacional, além de envolver conhecimentos básicos de mecânica, cinemática, automação, hidráulica, informática e inteligência artificial, utiliza recursos pedagógicos para que se estabeleça um ambiente de trabalho escolar agradável (GOMES, 2010).

Melo (2009) faz uma abordagem relacionando a Robótica educacional e a Resolução de Problemas utilizando o sistema LEGO MINDSTORMS para alunos do $12^{\circ}$ ano. Foi realizada uma experiência em que os sujeitos tinham de resolver um conjunto de problemas de robótica durante $o$ ano letivo. Foi realizada uma abordagem comparativa entre um grupo experimental e um grupo de controle. Os resultados da investigação revelaram que o grupo experimental sofreu uma evolução significativa em relação ao outro. Quanto a análise do processo, ainda segundo Melo (2009) "os sujeitos usam uma estratégia que corresponde à sequência: representação do problema, estabelecimento do plano, experimentação da proposta de solução, observação/análise do comportamento do robô e tomada de uma decisão sobre a reformulação do plano ou o avanço para uma nova etapa"

Assim como o trabalho de Melo (2009), Maliuk (2009) utilizou o sistema LEGO MINDSTORM como recurso pedagógico para aplicação dos experimentos em robótica educacional. Em sua metodologia, a turma foi dividida em grupos com quatro componentes: um líder/coordenador, um organizador, um construtor e um programador. As funções são trocadas em cada encontro, possibilitando que todos trabalhem em cada função. Pode-se destacar o trabalho em equipe, onde os alunos puderam, de forma colaborativa, realizar os experimentos propostos.

Pinto (2011), propõe a utilização do Arduino e componentes eletrônicos de baixo custo. Para ele, a robótica aplicada à educação pode contribuir para a motivação de professores e alunos e no desenvolvimento de habilidades importantes, como a autonomia, o raciocínio lógico e o trabalho cooperativo. Propõe o uso de hardwares e softwares abertos (open source), permitindo mais facilmente, o acesso em instituições públicas de ensino. $\mathrm{O}$ foco foi a formação de professores na área de robótica. O autor Pinto (2011) conclui que “... o trabalho proposto nesta pesquisa colaborou significativamente para a inserção da robótica educacional no cotidiano dos professores participantes".

O trabalho de Silva (2013), utilizou componentes eletrônicos acoplados ao Arduino para criar um Carro Segue Linha. Com o custo total de $\mathrm{R} \$ 224,80$, adquirindo uma placa Arduino, Sensores, Motores, Chassi de plástico e outros componentes foi possível realizar o teste do carro em um circuito oval.

Existem vários projetos, facilmente encontrados na Internet, os quais utilizam a impressora 3D para imprimir objetos que ganham vida através do acoplamento de componentes eletrônicos em suas partes utilizando a plataforma Arduino. Pode-se ver diversos modelos de drones, carros controlados remotamente, robôs e tantos outros, compartilhados na rede e na maioria gratuitos.

Por exemplo, o Robô Otto, figura 2, cujo projeto é aberto, está disponível para download e é compatível com o Arduino, imprimível em 3D e personalizável. Este robô 
pode ser programado para andar, desviar de obstáculos, dançar, emitir som e até simular em sua face um sentimento, podendo ser controlado através de um dispositivo móvel (OTTO, 2018). Os arquivos dos modelos 3D para serem impressos em uma impressora 3D podem ser baixadas no repositório do Thingiverse (THINGIVERSE, 2017).

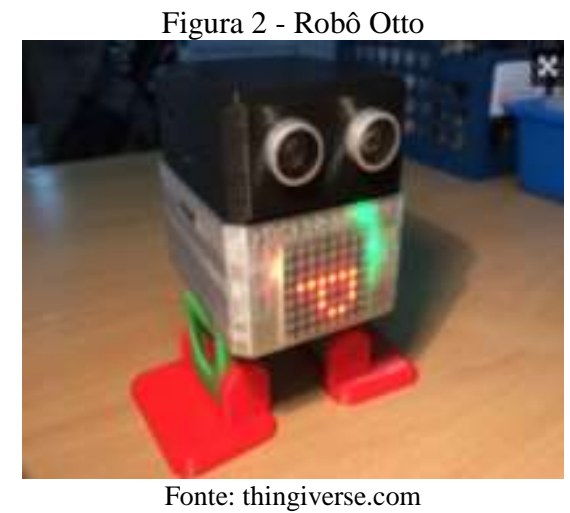

Esta pesquisa visa estimular pesquisadores, professores e alunos na utilização dos recursos educacionais apresentados e na participação do Movimento Maker, utilizando impressoras 3D, colocando a "mão na massa" e criando novos produtos.

\section{METODOLOGIA}

O percurso metodológico utilizado para atingir o objetivo deste trabalho foi a realização de uma pesquisa documental no portal oficial da rede FabLab de todos os laboratórios de fabricação digital do Brasil com certificação pelo MIT, levantando o seu ranking em relação a outros países e sua distribuição entre os estados brasileiros. Os dados obtidos são comparados a um trabalho similar realizado em 2016, analisando o crescimento da quantidade de laboratórios implantados.

Também foi realizada uma busca documental no portal de periódicos CAPES, dos trabalhos que aplicaram a robótica na educação com ênfase na utilização de impressora 3D, do sistema LEGO MINDSTORMS e do Arduino, uma placa de microprocessamento de baixo custo, analisando suas ações e os artefatos. Por fim, foi realizado um cotejamento dos dados e as suas relações entre a cultura Maker e a educação.

\section{RESULTADOS E DISCURSÕES}

\section{A. FabLabs}

No Brasil, há uma crescente implantação de FabLabs. Esta seção traz o resultado do levantamento dos FabLabs brasileiros, o seu grau de importância em sua rede e faz um comparativo com o trabalho de Pinto (2016), que também realizou uma pesquisa similar em 2016.

Foram identificados através do portal da rede FabLab (FABLAB FOUNDATION, 2018), 1305 FabLabs em todo o Mundo, dentre eles, 180 estão nos Estados Unidos, país com maior número de Laboratórios, em seguida aparece a França com 162 unidades e a Itália com 139. O Brasil aparece na sétima colocação com 49 FabLabs, conforme a Tabela 1. Em 2016, o Brasil tinha 17 FabLabs (PINTO, 2016), sendo verificado um crescimento de 32 Laboratórios em apenas dois anos. Com isso, sua colocação no ranking subiu do $8^{\circ}$ lugar para o $6^{\circ}$, considerando a quantidade de unidades por país se igualando com a Alemanha.

Tabela 1 - Países x Quantidades de FabLabs

\begin{tabular}{|c|c|c|c|}
\hline $\begin{array}{l}\text { Ranking } \\
\text { em } 2018\end{array}$ & País & $\begin{array}{c}\text { Qt FabLabs } \\
2016 \\
\text { (PINTO, 2016) }\end{array}$ & $\begin{array}{c}\mathrm{Qt} \\
\text { FabLabs } \\
\mathbf{2 0 1 8}\end{array}$ \\
\hline $1^{\circ}$ & Estados Unidos & 120 & 180 \\
\hline $2^{\circ}$ & França & 84 & 162 \\
\hline $3^{\circ}$ & Itália & 69 & 139 \\
\hline $4^{\circ}$ & Espanha & 47 & 53 \\
\hline $5^{\circ}$ & Índia & 16 & 50 \\
\hline $6^{0}$ & Brasil & 17 & 49 \\
\hline $6^{\circ}$ & Alemanha & 31 & 49 \\
\hline $7^{\circ}$ & Inglaterra & 28 & 42 \\
\hline
\end{tabular}

No Brasil, observa-se que São Paulo continua sendo o estado que apresenta o maior número de FabLabs com 18 unidades em 2018 contra 4 em 2016 (PINTO, 2016), seguido do Rio Grande do Sul com 6 FabLabs. A Figura 2 ilustra o número de FabLabs no Brasil, distribuídos por estado. Observa-se que os estados do Piauí, Ceará, Bahia, Sergipe, Mato Grosso e Goiás adquiriram laboratórios após 2016.

$\mathrm{Na}$ Bahia, em 2017 (figura 3), foram implantados 2 laboratórios de fabricação digital com o selo do FabLab, um na cidade de Camaçari e outro em Itabuna (FABLAB FOUNDATION, 2018). Apesar de só existirem dois FabLabs no estado, existem outros espaços makers similares aos filiados ao MIT, como o IHAC Lab da Universidade Federal da Bahia (UFBA) e o Mandacaru Lab da Universidade do Estado da Bahia (UNEB), ambos disseminando a cultura maker entre a comunidade acadêmica.

Figura 3 - FabLabs no Brasil - Qt 2018 e Qt 2016

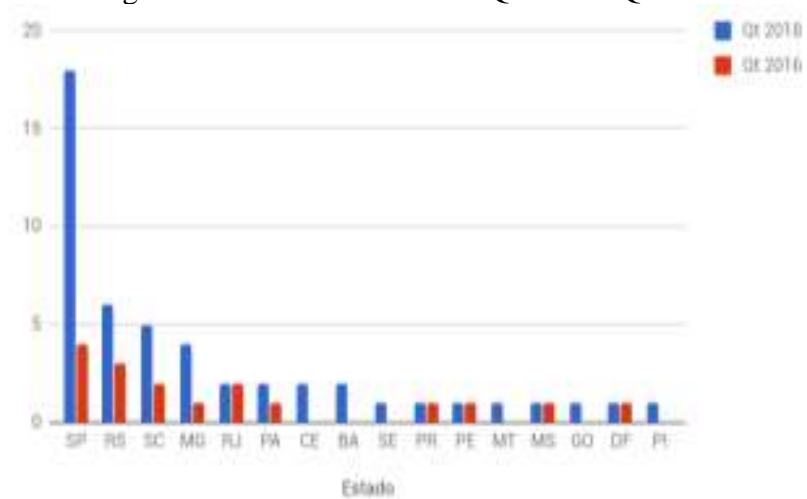

Fonte: Autores, 2017.

A cultura Maker está disseminada através das mídias digitais e oferece elementos para a criação de uma nova escola centrada no aluno, onde ele pode ser o protagonista no processo de aprendizagem por meio da experimentação. É neste contexto que a adoção de uma nova proposta educacional, segundo um ambiente de aprendizagem lúdico que adote conceitos de fabricação digital e robótica educacional podem ser considerados importantes elementos no direcionamento à inovação na educação.

Neste contexto, os FabLabs vêm colaborando para repensar a educação convencional dentro das universidades e da comunidade em seu entorno. Estes estão presentes em vários países do mundo, chegando a 1305 unidades. O 
Brasil está em sexto lugar em quantidade de laboratórios filiados a rede $F a b L a b$, ficando atrás dos Estados Unidos, França, Itália, Espanha e Índia. Houve um grande crescimento em relação a 2016, passando de 17 para 49 unidades. O levantamento demonstrou que as regiões sudeste e sul possuem 36 FabLabs. Esse crescimento demonstra o interesse pela cultura Maker no Brasil.

\section{B. Robótica Educacional}

Através de uma pesquisa no portal de periódicos da CAPES, foram encontrados: 63 trabalhos com as palavraschave "robótica educacional", 24 com as palavras-chave "Arduino" e "educação" e 31 publicações com as palavraschave "impressão 3D" e "educação". Todavia, quando foi realizada a pesquisa com as palavras-chave "impressão 3D" e "Arduino", apenas uma publicação foi encontrada, não sendo relacionada com educação. Pode-se supor que existem poucas ações que utilizam a robótica aliada a impressão 3D com finalidade educacional.

A maioria dos trabalhos pesquisados utilizaram o sistema LEGO MINDSTORM. A LEGO criou em 1985 o seu primeiro kit de robótica o LEGO TECHNIC e em 1998 o LEGO MINDSTORMS (LEGO, 2018). Seus kits de robótica educacional podem ser adquiridos em diversas lojas online por qualquer pessoa interessada. Em sua loja oficial "lego.com", o modelo LEGO MINDSTORM EV3 (figura 4) é vendido por $\mathrm{R} \$ 1.999,99$, contendo vários blocos de montar, uma estação programável, um sensor de cores, um sensor de toque, um sensor infravermelho, dois motores grandes e um motor médio. Além disso, na mesma loja, existem uma variedade de opções, dependendo da escolha do produto, o valor pode ultrapassar os R \$ 5.000,00 (LEGO, 2018).

Figura 4 - Lego Mindstorm EV3

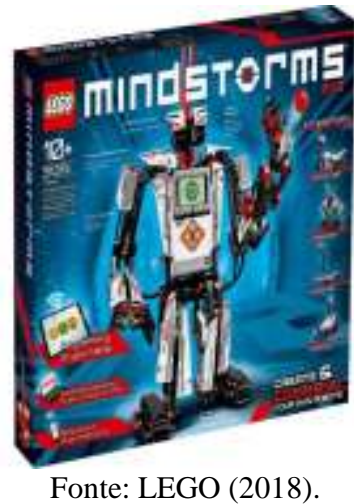

Alguns dos trabalhos pesquisados utilizaram componentes eletrônicos acoplados a uma placa de prototipação chamada Arduino, muito utilizada pelos Makers em todo o planeta e amplamente difundido pela comunidade na internet. De baixo custo, comparado ao sistema LEGO MINDSTORMS, um kit (figura 5) contendo uma placa Arduino e diversos componentes como sensores, motores, display LCD (Liquid Crystal Display), LEDs (Light Emitting Diode), teclado e botões, na loja online "baudaeletronica.com.br" pode ser adquirido por R $\$ 260,36$ (BAÚ, 2018), possibilitando que as escolas apliquem oficinas de robótica abordando temas relacionados à eletrônica, geração e transformação de energia, sensores e componentes eletromecânicos, linguagem de programação, lógica, comunicação, língua estrangeira, etc (FABRI, 2014).

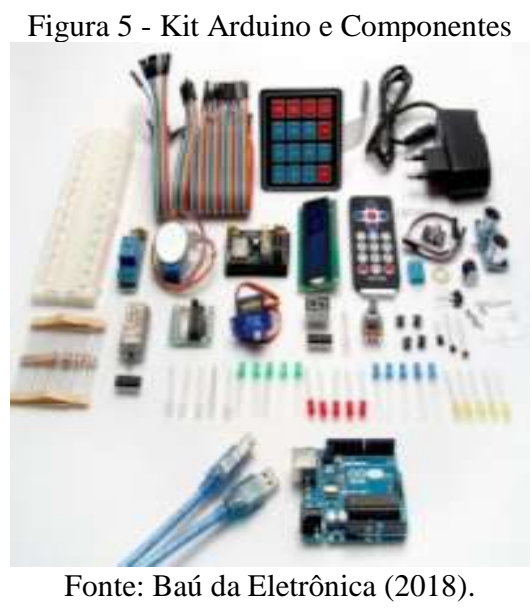

\section{CONCLUSÃO}

Este artigo apresentou aspectos da Cultura Maker e dos laboratórios de fabricação digital, detalhando como o uso da impressora 3D e da Robótica Educacional está sendo aplicados na educação. Observou-se uma tendência do crescimento de novos laboratórios abertos no Brasil através de uma pesquisa realizada no portal oficial da rede FabLab. Outra pesquisa realizada, através dos periódicos CAPES, foram as publicações que aplicaram a robótica na educação com ênfase na utilização de impressora 3D.

A correlação entre estas duas pesquisas trousse um cenário que apesar da crescente implantação de FabLabs no Brasil ainda existem poucas ações que utilizam a robótica aliada a impressão 3D com finalidade educacional.

Apesar disso, existem projetos abertos na internet (como o Robô Otto apresentado no final da seção IV. ROBÓTICA EDUCACIONAL) que trazem a junção de objetos criados através da impressora 3D com componentes eletrônicos. Projetos acadêmicos podem se beneficiar de atividades de modelagem 3D, impressão e automação para reduzir as questões abstratas inerentes a alguns conteúdos. A Robótica Educacional associada a Impressão 3D em ambientes de fabricação digital visa estimular a criatividade através da realização de práticas onde o aluno coloca a mão na massa, e assim trabalha à construção do conhecimento através da resolução de problemas do seu cotidiano.

\section{REFERÊNCIAS}

AGUIAR, Leonardo De Conti Dias. Um Processo Para Utilizar A Tecnologia De Impressão 3d Na Construção De Instrumentos Didáticos Para O Ensino De Ciências. Faculdade De Ciências - Campus De Bauru. Programa De Pós-Graduação Em Educação Para A Ciência. Ano 2016.

ANDERSON, Chris. Makers, A Nova Revolução Industrial. Editora Elsevier. Ano: 2012

BAÚ, da eletrônica. Loja online. Disponível em: <www.baudaeletronica.com.br>. Acesso em: 20/10/2018.

BORDINI, Adriana. Computação na Educação Básica no Brasil: o Estado da Arte. RITA, Revista de Informática Teórica e Aplicada. V.23, n 2. Ano: 2016.

CAPES. Portal de Periódicos CAPES. Disponível em: <www.periodicos.capes.gov.br/>, acesso em: 20/07/2018.

FABLAB FOUNDATION. Disponível em: <http://www.fabfoundation.org/> acesso em 04/09/2018. 
FABRI JUNIOR, Luiz A. et al. Usando a Plataforma Arduino para Criação de Kit Pedagógico Baseado em Oficinas De Robótica para Introdução à Engenharia no Ensino Médio. Perspectivas em Ciências Tecnológicas, v. 3, n. 3, p. 68-77. Ano 2014.

FIRJAN, Sistema. Mapeamento da Indústria Criativa no Brasil. Disponível em: https://www.firjan.com.br/economiacriativa/download/mape amento-industria-criativa-sistema-firjan-2016.pdf $>$ Ano 2016.

GAVASSA, Regina C. F. B. et al. Cultura Maker, Aprendizagem Investigativa por Desafios e Resolução de Problemas na SME-SP (Brasil). FLBrazil. Ano 2016.

GOMES, Cristiane Grava, et. al. PIROLA, NA. org. Ensino de ciências e matemática, IV: temas de investigação. São Paulo: Editora UNESP; São Paulo: Cultura Acadêmica, 2010.

HATCH, Mark. The Maker Movement Manifesto. McGraw-Hill Education eBooks. Ano: 2014

LEGO. A história do LEGO Group. Disponível em: <www.lego.com>. Acesso em: 27/05/2018.

MALIUK, Karina Disconsi. Robótica Educacional como cenário investigativo nas aulas de matemática. Universidade Federal do Rio Grande do Sul, Programa de Pós Graduação do Ensino de Matemática. Ano: 2009.

MELO, Mário Marcelino Luís de. Robótica e Resolução de Problemas: Uma Experiência com o Sistema Lego Mindstorms no $12^{\circ}$ ano. Universidade De Lisboa, Faculdade De Psicologia E De Ciências Da Educação. Ano: 2009.

OTTO, Robot. Build your own robot. Disponível em: https://www.ottodiy.com/. Acesso em: 04/09/2018

PINTO, Marcos de Castro. Aplicação de arquitetura pedagógica em curso de robótica educacional com hardware livre. 2011. 158 f. Dissertação (Mestrado em Informática) - Instituto de Matemática, Núcleo de Computação Eletrônica, Universidade Federal do Rio de Janeiro, Rio de Janeiro, 2011.

PINTO, Sofia L. U., et al. O Movimento Maker: Enfoque nos Fablabs Brasileiros. ANPROTEC, 26 ${ }^{\mathrm{a}}$ Conferência. Ano: 2016.

REIS, Caroline Dias Paim de Souza. Conhecimento em Computação como Fator Preponderante para Definição da Área de TI como Curso Superior. Universidade Salvador - Unifacs, Programa de Pós-graduação em Sistema e Computação. Ano 2017.

SILVA, Rodrigo Barbosa. Abordagem crítica de robótica educacional: Álvaro Vieira Pinto e Estudos de Ciência, Tecnologia e Sociedade. Universidade Tecnológica Federal do Paraná, Programa De Pós-graduação em Tecnologia. Ano: 2012

SILVA, Francisco Ioneiton da Silva, et al. Praxedes: Protótipo de Um Kit Educacional de Robótica Baseado na Plataforma Arduino. Revista: EaD e Tecnologias Digitais na Educação, Dourados, MS, n 1, v..1. Ano: 2013.

SOARES, Juliana Maria Moreira, et al. Design e prototipagem de um dispositivo de mobilidade com uso de tecnologias de impressão e escaneamento $3 \mathrm{D} .18^{\circ}$
Congresso Brasileiro de Ergonomia. ISSN 2358-5463. Ano: 2016.

\section{COPYRIGHT}

Direitos autorais: Os autores são os únicos responsáveis pelo material incluído no artigo.

Submetido em: $14 / 09 / 2018$

Aprovado em: 11/12/2018 


\author{
Revista SODEBRAS - Volume 14 \\ $\mathrm{N}^{\circ} 157$ - JANEIRO/ 2019
}

\title{
OBTENÇÃO, CARACTERIZAÇÃO E AVALIAÇÃO DA ATIVIDADE ANTIMICROBIANA DE FILME POLIMÉRICO DE GELATINA EXTRAÍDA DAS ESCAMAS DE TILÁPIA CONTENDO COMO CARGA O SALICILATO DE COBALTO(II)
}

\author{
OBTAINING, CHARACTERIZATION AND THE ANTIMICROBIAL \\ EVALUATION OF THE POLYMERIC FILM OF GELATIN EXTRACTED FROM \\ THE TILAPIA SCALES CONTAINING COBALT(II) SALICYLATE AS LOAD
}

\author{
KAUANI CALDATO; FILIPE KIALIL DA SILVA NEVES; GABRIELLE CRISTINA CALEGARI; VIDIANY \\ APARECIDA QUEIROZ SANTOS; MARIO ANTÔNIO ALVES DA CUNHA; LEANDRO ZATTA \\ UNIVERSIDADE TECNOLÓGICA FEDERAL DO PARANÁ - CÂMPUS PATO BRANCO \\ kauani96caldato@gmail.com,lipe-kalil@hotmail.com,gabrielleccalegari@gmail.com, \\ vidianyqueiroz@yahoo.com.br,mcunha@utfpr.edu.br,leandrozatta@utfpr.edu.br
}

\begin{abstract}
Resumo - Este trabalho mostra a síntese e caracterização por diferentes técnicas, de um filme polimérico de gelatina extraída das escamas de tilápia contendo como carga o salicilato de cobalto(II). O trabalho se destaca por empregar uma rota alternativa e pouco reportada na literatura para a obtenção da carga empregada. O filme obtido apresentou boa atividade antimicrobiana frente às bactérias Staphylococcus aureus $e$ Escherichia coli. Devido às propriedades apresentadas, o material apresenta potencialidade de ser aplicado como bandagem de feridas.
\end{abstract}

Palavras-chave: Nanocompósito. Filme de gelatina. Salicilato de cobalto (II).

Abstract-The work shows the synthesis and characterization of
a polymeric film of gelatin extracted from tilapia scales. Different
production techniques were used and Cobalt salicylate (II) was
used as the charge. An alternative, method not reported in the
literature, was studied to obtain the charge. The film obtained
presented antimicrobial activity against the bacteria
Staphylococcus aureus and Escherichia coli. The results suggest
that the film presents potential for application in the
pharmacological area, especially as a wound dressing.

Keywords: Nanocomposite. Gelatin film. Cobalt (II) salicylate.

\section{INTRODUÇÃO}

A gelatina consiste em uma mistura de proteínas solúveis em água, compostas por aminoácidos de cadeias longas interconectadas por ligações peptídicas. É obtida a partir da hidrólise parcial do colágeno (AL-SAIDI et al., 2012; HUANG et al., 2016; LIU; HUANG, 2014; NURUL; SARBON, 2015; PIASEK; URBANSKI, 1962).

A gelatina é comumente empregada nas indústrias de alimentos, cosméticos, embalagens e farmacêutica (HUANG et al., 2016). Atualmente, estudos têm mostrado a potencialidade de aplicar a gelatina como fonte precursora de diferentes materiais alternativos aos obtidos a partir de derivados de petróleo, como compósitos, biocompósitos e polímeros biodegradáveis (IMANIEH; AGHAHOSSEINI, 2013; MERINA et al., 2017), os quais se destacam por apresentarem propriedades como não toxicidade, não irritabilidade e compatibilidade com corpos vivos (XIAO et al., 2002).

Aproximadamente $95 \%$ da gelatina comercial é extraída a partir de derivados de animais mamíferos (SOCKALINGAM; ABDULLAH, 2015), como pele e ossos de bois e porcos (AL-SAIDI et al., 2012; HUANG et al., 2016), porém, essas fontes apresentam problemas relacionados à questões religiosas, sociais e doenças, como a vaca louca ou Spongiform encephalopathy bovina (GHALY et al., 2013; MERINA et al., 2017), os quais, juntamente com a demanda global por colágeno e seus derivados, motivam o estudo e desenvolvimento de processos de extração a partir de fontes alternativas não mamíferas (SILVA; PENNA, 2012), como peixes e seus resíduos.

Os resíduos gerados a partir da produção e processamento de peixes é um problema crescente, principalmente por desencadear impactos ambientais (MERINA et al. 2017; SOCKALINGAM; ABDULLAH, 2015). Na indústria do processamento de peixes são gerados de 20 à $80 \%$ de resíduos, dependendo do nível de processamento e tipo de peixe (BHAGWAT; DANDGE, 2016; PICKLER; FILHO， 2017; SOCKALINGAM; ABDULLAH, 2015). As escamas correspondem de 2 à $4 \%$ do resíduo seco (GHALY et al., 2013). Na atividade pesqueira, as escamas de peixe geralmente são descartadas no lixo (SANTOS et al., 2009) ou jogadas no mar (GHALY et al., 2013).

As escamas de peixes são biocompósitos compostos por duas fases, uma orgânica, contendo alto teor de proteínas como colágeno (HUANG et al., 2016), queratina e mucina, sendo que os teores desses compostos são diferentes para cada espécies de peixe (SOCKALINGAM; ABDULLAH. 2015). A segunda fase, de natureza inorgânica, é composta por hidroxiapatita e teores de carbonato de cálcio (MARTINS et al., 2015; SOCKALINGAM; ABDULLAH, 2015).

A tilápia é uma das espécies de peixe de água doce mais produzidas mundialmente e se destaca pela 
durabilidade, rápido crescimento e resistência à doenças (MOHAMMAD; KUMAR; BASHA, 2014; PICKLER; FILHO, 2017). Em termos de resíduos da produção da carne, cerca de $1 \%$ da massa se deve às escamas, as quais, geralmente são descartadas em efluentes ou destinadas para a fabricação de ração animal (CHAGURI, 2010; PICKLER, FILHO, 2017).

Com os dados anteriormente relatados, verifica-se a importância da pesquisa e desenvolvimento de tecnologias para aproveitar o colágeno presente nas escamas de peixes. A gelatina obtida de resíduos de peixe pode ser aplicada como precursor na obtenção de filmes poliméricos e (nano)compósitos.

Filmes poliméricos de gelatina apresentam boas propriedades mecânicas (WENG; ZHENG, 2015) e baixa permeabilidade de oxigênio. Estas propriedades possibilitam diferentes aplicações, como embalagem de alimentos, entre outras, sendo que as propriedades dos materiais podem ser melhoradas com a incorporação de aditivos (cargas) (AVENA-BUSTILLOS et al., 2006).

É conhecido que compostos de cobalto, além de apresentarem uma alta estabilidade estrutural, são amplamente estudados e aplicados na área de nanotecnologia. Se destacam por apresentarem atividades biológicas (antifúngica e antioxidante) e boas propriedades ópticas e magnéticas (DAS et al., 2011; NETHRAVATHI et al., 2007; SHALASH; ABU, 2017).

Materiais baseados em salicilatos de metais de transição são amplamente empregados na medicina por possuírem efeitos múltiplos em processos metabólicos e biológicos (KISHORE; NAGARAJAN, 1981; PRAVEEN ET AL., 2016). Apresentam alta porosidade e área superficial (DAS ET AL., 2011) e quando aplicados em polímeros como aditivos (cargas), conferem melhoras nas propriedades térmicas, como maior retardo ao processo de ignição (KISHORE; NAGARAJAN, 1981).

Este trabalho objetivou, inicialmente, a obtenção do hidroxisalicilato lamelar de cobalto(II), porém, a partir de análises preliminares, verificou-se que foi obtido o composto salicilato de cobalto(II) por um método alternativo ao comumente relatado na literatura. $\mathrm{O}$ material obtido foi aplicado como carga na obtenção de um filme polimérico de gelatina extraída de escamas de tilápia, contendo o glicerol como plastificante. Os materiais foram caracterizados por diferentes técnicas. Dentre os resultados obtidos, destaca-se a boa atividade antimicrobiana do filme contendo o salicilato como carga.

\section{MÉTODOS}

\section{1- Extração da gelatina}

As escamas de tilápia foram fornecidas por um produtor do município de Pato Branco - PR. Assim que extraídas, as escamas foram lavadas em água corrente para remover o excesso de resíduos, peneiradas e congeladas em freezer até o processo de extração da gelatina.

$\mathrm{O}$ processo de extração foi adaptado de um procedimento reportado na literatura (MARTINS et al., 2015). Após descongeladas, as escamas foram secas em estufa à $40{ }^{\circ} \mathrm{C}$ durante $40 \mathrm{~h}$, em seguida, $100 \mathrm{~g}$ das escamas foram separadas e misturadas a uma solução de concentração $10 \%(\mathrm{~m} / \mathrm{v})$ de cloreto de sódio $(\mathrm{NaCl}$, Reatec, $99 \%)$, na proporção $1: 10(\mathrm{~m} / \mathrm{v})$ durante $24 \mathrm{~h}$ à temperatura ambiente. Em seguida, as escamas foram lavadas com água destilada, peneiradas e misturadas, na proporção 1:10 (m/v), a uma solução de ácido clorídrico ( $\mathrm{HCl}$, Reatec, 37\%) de concentração 0,4 mol. $\mathrm{L}^{-1}$ durante $24 \mathrm{~h}$. O material resultante foi lavado com água destilada, seco em estufa à $40{ }^{\circ} \mathrm{C}$ durante $24 \mathrm{~h}$ e trituradas em um liquidificador.

As escamas desmineralizadas e secas foram misturadas a uma solução de ácido acético $\left(\mathrm{CH}_{3} \mathrm{COOH}\right.$, Reatec, $\left.99,7 \%\right)$ de concentração de $0,1 \mathrm{~mol} . \mathrm{L}^{-1}$ na proporção $1: 10(\mathrm{~m} / \mathrm{v})$ durante $1 \mathrm{~h}$ à temperatura ambiente. Em seguida, o material resultante foi misturado à solução de hidróxido de sódio $\left(\mathrm{NaOH}\right.$, Reatec, 99\%) de concentração $0,1 \mathrm{~mol}^{-L^{-1}}$ na proporção de $1: 3(\mathrm{~m} / \mathrm{v})$ durante $1 \mathrm{~h}$, seguido de tratamento com solução 0,1 mol.L $\mathrm{L}^{-1}$ de ácido sulfúrico $\left(\mathrm{H}_{2} \mathrm{SO}_{4}\right.$, Reatec, $98 \%$ ) na proporção de $1: 3(\mathrm{~m} / \mathrm{v})$ durante $1 \mathrm{~h}$. Para cada etapa de troca de solução anteriormente descrita, o material sólido foi filtrado e lavado com água destilada.

A extração da gelatina se deu pela imersão do material em água destilada, na proporção de 1:4 (m/v) durante $2 \mathrm{~h}$ sob agitação e aquecimento a $60{ }^{\circ} \mathrm{C}$. O resíduo sólido (escamas) foi separado e descartado, e a solução obtida (colágeno hidrolisado) foi armazenada em geladeira até ser submetida ao processo de liofilização.

A solução de gelatina foi transferida para um recipiente de poliestireno, congelada em freezer durante 24 h e liofilizada em um equipamento marca LIOTOP, modelo L108. O processo ocorreu durante $76 \mathrm{~h}$, sob temperatura de $-53{ }^{\circ} \mathrm{C}$ e pressão de $54 \mu \mathrm{mHg}$.

\section{2 - Síntese do salicilato de cobalto(II)}

Inicialmente foi realizada a síntese do precursor baseado no hidróxiacetato lamelar de cobalto(II) (HACo) pela síntese hidrotérmica com a ureia.

Em um reator tipo autoclave, foram misturados 4,5 g de acetato de cobalto(II) $\left(\mathrm{Co}\left(\mathrm{CH}_{3} \mathrm{COO}\right)_{2}\right.$, Reatec, $\left.98,1 \%\right)$ com 7,5 mL de água destilada e $1,08 \mathrm{~g}$ de ureia $\left(\mathrm{CH}_{4} \mathrm{~N}_{2} \mathrm{O}\right.$, Proquímios, 98,2\%). A mistura foi aquecida à $140{ }^{\circ} \mathrm{C} \mathrm{em}$ uma estufa durante $1 \mathrm{~h}$. O material obtido foi lavado com água destilada e seco à $60^{\circ} \mathrm{C}$ durante $24 \mathrm{~h}$.

Para a síntese do salicilato de cobalto (Co-S) a massa de $0,2 \mathrm{~g}$ do precursor HACo foi dispersada em $20 \mathrm{~mL}$ de uma solução de etanol $\left(\mathrm{C}_{2} \mathrm{H}_{5} \mathrm{OH}\right.$, Neon, 99,8\%) de concentração $0,8 \mathrm{~mol} \cdot \mathrm{L}^{-1}$, sob agitação e aquecimento de $60^{\circ} \mathrm{C}$. Foram adicionados $2,76 \mathrm{~g}$ de ácido salicílico $\left(\mathrm{C}_{7} \mathrm{H}_{6} \mathrm{O}_{3}\right.$, Isofar, $\left.99 \%\right)$ e o $\mathrm{pH}$ foi ajustado para 8 com a adição de gotas de uma solução 1 mol.L ${ }^{-1}$ de $\mathrm{NaOH}$ (Reatec, $99,0 \%)$. O sistema foi mantido sob agitação e temperatura de $60{ }^{\circ} \mathrm{C}$ durante $5 \mathrm{~h}$ em seguida mantida, novamente, sob agitação, porém à temperatura ambiente durante 19 horas. $\mathrm{O}$ material resultante foi lavado com água destilada e seco em estufa a $60{ }^{\circ} \mathrm{C}$ por $24 \mathrm{~h}$.

\section{3 - Síntese do filme polimérico}

O filme sem (FG) e com adição de carga (FG-Co-S) foram obtidos pelo método casting.

Para a obtenção do filme FG, o preparo da solução filmogênica ocorreu com a solubilização da gelatina em água ultra purificada a uma proporção de $4 \%(\mathrm{~m} / \mathrm{v})$ sob agitação e aquecimento de $40 \quad{ }^{\circ} \mathrm{C}$ até completa homogeneização. Em seguida, o glicerol $\left(\mathrm{C}_{3} \mathrm{H}_{8} \mathrm{O}_{3}\right.$, Reatec, $99,5 \%$ ) foi adicionado à solução na proporção de $20 \%$ em relação à massa de gelatina, sendo a solução resultante submetida a agitação por 20 minutos sob $40^{\circ} \mathrm{C}$. 
Para o filme FG-Co-S, foi realizado o preparo da solução filmogênica da mesma maneira que para o filme FG, porém, após o preparo da mistura (gelatina-águaglicerol) a carga $\mathrm{Co}-\mathrm{S}$ foi adicionada $(4 \%$ em relação à massa de gelatina) e a solução resultante foi submetida ao banho de ultrassom (Cristofoli, $42 \mathrm{kHz}$ ) sob temperatura de $60{ }^{\circ} \mathrm{C}$ durante $30 \mathrm{~min}$.

As soluções precursoras dos filmes FG e FG-Co-S foram transferidas para formas de silicone com $4 \mathrm{~cm} \mathrm{de}$ diâmetro. Os materiais foram secos em estufa de circulação de ar a uma temperatura constante de $40{ }^{\circ} \mathrm{C}$, durante 48 horas. Os filmes obtidos foram retirados das placas com o auxílio de uma pinça e deixados em um dessecador contendo sílica gel.

\section{4 - Caracterizações}

Análise por difratometria de raios $\mathrm{X}$ método pó (DRX): As análises por DRX, foram realizadas em um difratômetro Rigaku, modelo MiniFlex 600, operando com fonte de radiação de cobre $\left(\mathrm{CuK}_{\alpha}\right.$ de $1,5418 \AA$ A ) a $40 \mathrm{kV}$ e corrente de $15 \mathrm{~mA}$. As análises foram realizadas com velocidade de varredura de $4,0^{\circ} \min ^{-1}$ na faixa de $3^{\circ}$ a $70^{\circ}(2 \theta)$. As amostras foram depositadas em porta amostras de vidro.

Espectroscopia no Infravermelho por Transformada de Fourier (IVTF): Análises de IVTF foram realizadas em equipamento Perkim-Elmer, modelo Frontier, pelo método de refletância total atenuada (ATR) em cristal de diamante. As leituras foram realizadas na faixa de 4000-400 $\mathrm{cm}^{-1}$, resolução de $4 \mathrm{~cm}^{-1}$ e acúmulo de 32 varreduras.

Espectrometria de refletância difusa (UV-Vis): Os espectros de refletância difusa foram obtidos em um espectrômetro Avantes, modelo AVASPEC-ULS3648-2USB2 com lâmpada de tungstênio-halogênio e sonda de fibra óptica.

Solubilidade do filme: Filmes com $1 \mathrm{~cm}^{2}$ de área foram recortados e inseridos em placas de petri (previamente taradas), e aquecidos a $45{ }^{\circ} \mathrm{C}$ durante $1 \mathrm{~h}$. As massas dos filmes após o aquecimento prévio foram determinadas. Em seguida, adicionou-se um volume de $10 \mathrm{~mL}$ de água destilada em cada placa de petri, o sistema foi mantido coberto e em repouso durante $24 \mathrm{~h}$, após este tempo, toda a água foi retirada com o auxílio de uma pipeta e os filmes foram secos sob $45{ }^{\circ} \mathrm{C}$ durante 6 horas. As massas dos filmes após a nova secagem foram determinadas e a solubilidade dos filmes foram obtidas pela Equação (1):

$$
\%_{\text {solubilidade }}=\frac{m_{f}-m_{i}}{m_{i}} \times 100 \%
$$

Onde: $\%_{\text {solubilidade }}=$ porcentagem de massa solubilizada em água; $\mathrm{m}_{\mathrm{f}}=$ massa final do filme; $\mathrm{m}_{\mathrm{i}}=$ massa inicial do filme .

Atividade antimicrobiana: A capacidade antimicrobiana foi determinada pelo método de difusão em ágar frente a Staphylococcus aureus (ATCC 25923) e Escherichia coli (ATCC 25922).

\section{RESULTADOS E DISCUSSÃO}

\section{1 - Síntese do salicilato de cobalto - Co-S}

A Figura 1 mostra os difratogramas de DRX dos precursores ácido salicílico HACo, ácido salicílico (AS) e da amostra Co-S.

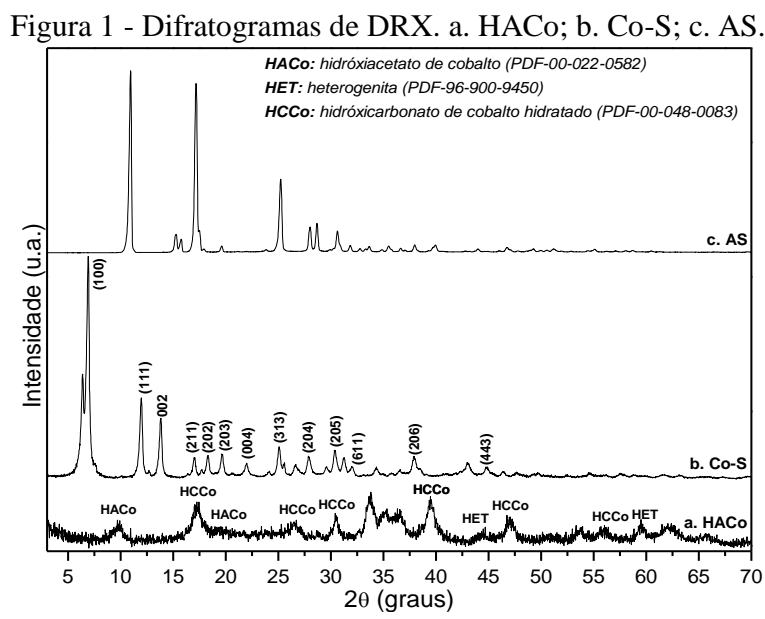

Fonte: Autores, 2018.

Inicialmente foi realizada a tentativa de síntese do precursor hidróxiacetato lamelar de cobalto (HACo), porém, pelo difratograma de DRX da amostra verificou-se que o material apresenta baixa cristalinidade e consiste em uma mistura das fases lamelares como hidróxiacetato de cobalto(II) (HACo), hidróxicarbonato de cobalto(II) (HCCo) e heterogenita (HET). Mesmo que a amostra HACo consistiu numa mistura de fases, a mesma foi submetida à tentativa de intercalação do ânion salicilato a partir do ácido salicílico objetivando um material lamelar mais cristalino.

Por comparação dos difratogramas de DRX dos precursores HACo (Figura 1 a.) e ácido salicílico (Figura 1 c.), verifica-se que a amostra Co-S (Figura 1b.) apresenta perfil de difração completamente distinto. De acordo com a literatura, os picos (indexados) se referem à fase salicilato de cobalto(II) obtido pelo método de precipitação (KISHORE; NAGARAJAN, 1981; PRAVEEN ET AL., 2016). Curiosamente, foi obtida uma fase não esperada, pois a rota de síntese empregada é comumente aplicada para o processo de intercalação em materiais lamelares, o que não ocorreu na modificação do precursor HACo. Vale destacar que não foram encontrados relatos na literatura empregando o procedimento de síntese proposto neste trabalho para a síntese do salicilato de cobalto(II) (Co-S).

As amostras HACo, AS e Co-S foram caracterizadas por IVTF e os espectros são mostrados na Figura 2.

A formação de salicilatos de metais é acompanhada pela análise da região entre $1700-1300 \mathrm{~cm}^{-1}$, nesta, são verificadas as vibrações antissimétrica e simétrica do grupamento carboxila $\left(\mathrm{COO}^{-}\right)$, as quais, para o ácido salicílico (Figura 2 a.), são observadas em 1652 e $1386 \mathrm{~cm}^{-1}$, respectivamente (TRIVEDI et al., 2015). Na amostra Co-S as vibrações anteriormente descritas são verificadas em 1600 e $1400 \mathrm{~cm}^{-1}$, indicando a coordenação do grupamento $\mathrm{COO}^{-}$ao íon $\mathrm{Co}^{2+}$, as quais estão de acordo com relatos da literatura (DAS et al., 2011). A diferença entre valores dos números de onda das vibrações antissimétrica e simétrica na amostra $\mathrm{Co}-\mathrm{S}$ é de $200 \mathrm{~cm}^{-1}$ o que indica que o ânion salicilato está coordenado ao centro metálico $\left(\mathrm{Co}^{2+}\right)$ (DEACON; PHILLIPS, 1980; NAKAMOTO, 2009). 
Figura 2 - Espectros de IVTF. a. HACo; b. Co-S; c. AS.

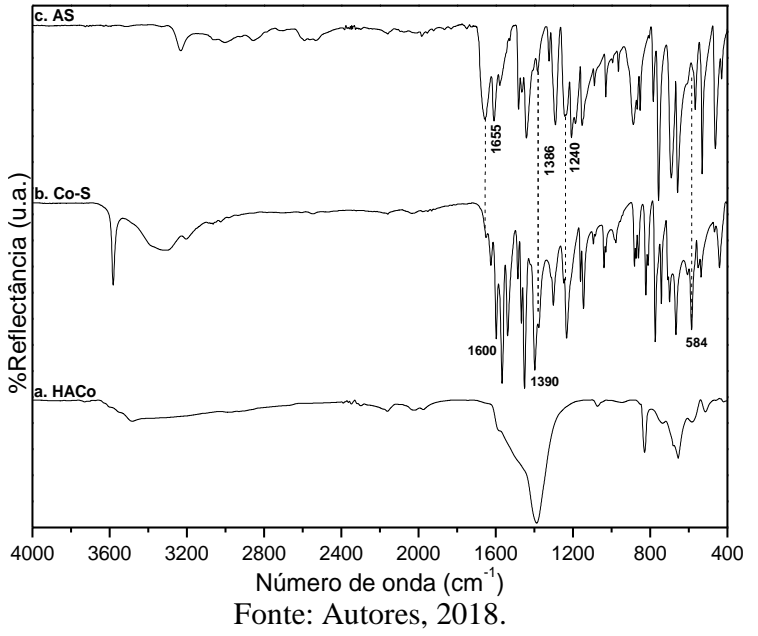

A vibração $\mathrm{C}-\mathrm{OH}$ em $1240 \mathrm{~cm}^{-1}$ do ácido salicílico também apresenta deslocamento quando da formação de salicilatos metálicos. $\mathrm{Na}$ amostra $\mathrm{Co}-\mathrm{S}$ essa é deslocada para $1234 \mathrm{~cm}^{-1}$, indicando interação do grupamento $\mathrm{C}-\mathrm{OH}$ com o íon $\mathrm{Co}^{2+}$. Comportamentos semelhantes são relatados na literatura (ALVAREZ-ROS; SÁNCHEZ-CORTÉS; GARCÍA-RAMOS, 2000).

\section{Caracterização do filme de gelatina contendendo o Co-S como carga}

A Figura 3 mostra os difratogramas de DRX dos filmes de gelatina sem adição de carga (FG) (Figura 3 a.) e do nanocompósito (FG-Co-S) contendo o Co-S (Figura 3 b.).

Figura 3 - Difratogramas de DRX. a. FG; b. FG-Co-S; c. Co-S.

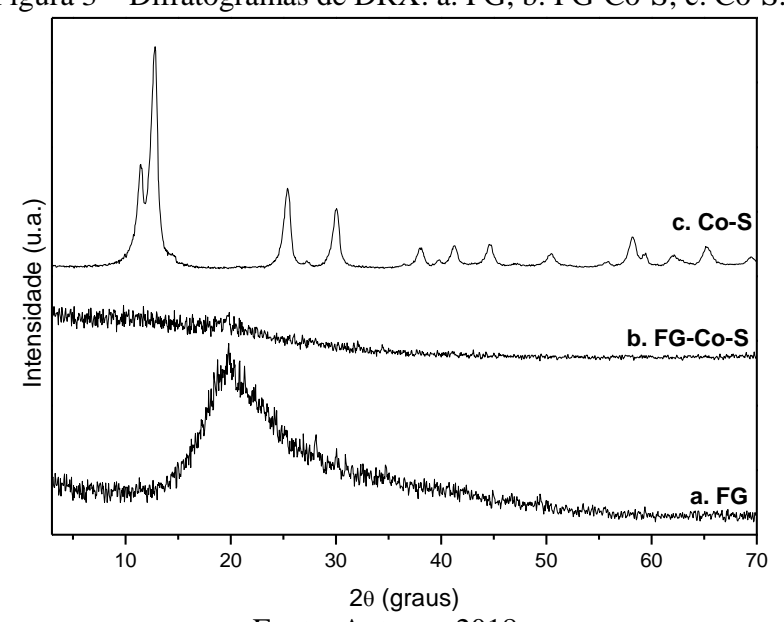

Fonte: Autores, 2018.

Observa-se no difratograma do filme FG (Figura 3 a.) um pico em torno de $20^{\circ}(2 \theta)$ indicando regiões onde ocorrem uma boa organização das cadeias do polímero. Comportamentos semelhantes são conhecidos na literatura (NOR; NAZMI; SARBON, 2017). Não são observados picos de difração quando da adição da carga Co-S no filme FG-Co-S (Figura 3 c.), indicando uma boa dispersão da carga na matriz polimérica.

A Figura 4 mostra os espectros de IVTF dos filmes FG e FG-Co-S e da carga Co-S.

Pela comparação do espectro de IVTF do filme sem adição da carga (FG) com o compósito (FG-Co-S), Figuras 4 a. b., respectivamente, verifica-se que a adição da carga Co-S não provocou alterações significativas nas vibrações características da matriz polimérica $(\mathrm{FG})$. A presença de ombros de vibrações em 584 e $1390 \mathrm{~cm}^{-1}$ no espectro da amostra FG-Co-S (Figura 4 b.) se destacam por serem vibrações características do salicilato de cobalto(II) (Co-S) e se devem e ao estiramento $\mathrm{Co}-\mathrm{O}$ e ao grupo $\mathrm{COO}^{-}$ coordenado ao íon $\mathrm{Co}^{2+}$, respectivamente (DAS et al., 2011; YANG et al., 2010).

Figura 4 - Espectros de IVTF. a. FG; b. FG-Co-S; c. Co-S.

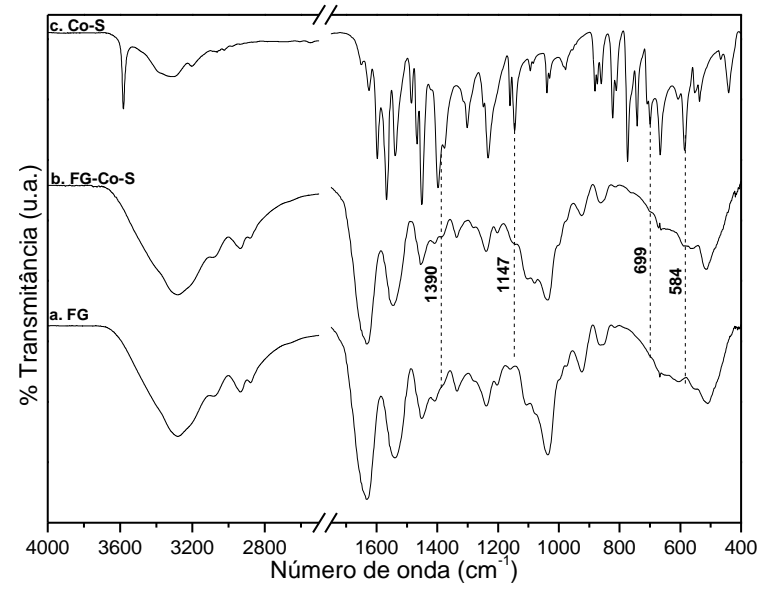

Fonte: Autores, 2018.

A Figura 5 mostra os espectros de refletância difusa na região do visível (UV-Vis) dos filmes.

Figura 5 - Espectro de refletância difusa de UV-Vis. a. FG; b. FGCo-S; c. Co-S

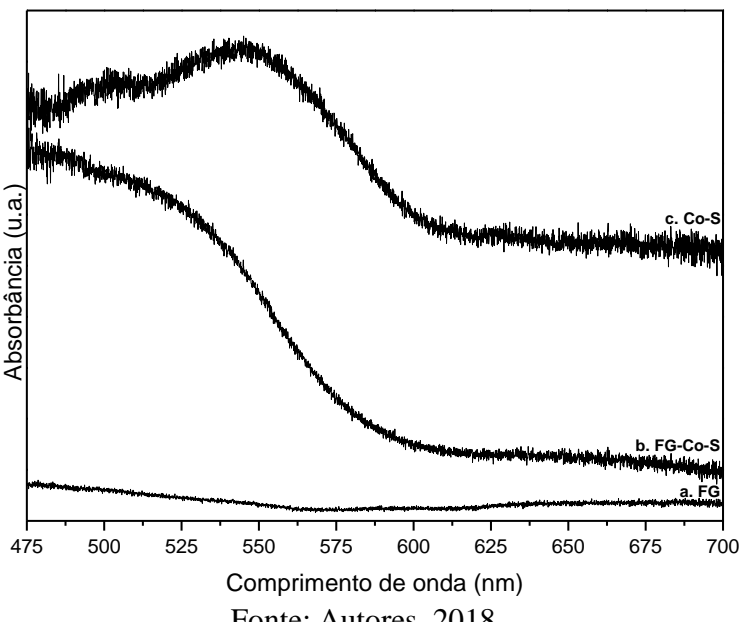

A amostra FG (Figura 5 a.) não apresenta picos de absorção na região do visível, possivelmente pela sua cor branca. Em relação à carga (amostra $\mathrm{Co}-\mathrm{S}$ - Figura 5 c.), a mesma apresenta um pico de absorção máxima em $545 \mathrm{~nm}$, a qual é característica para compostos de cobalto com coordenação octaédrica, os quais apresentam coloração rosa, a qual também é a cor do material Co-S (DAS et al., 2011; WANG et al., 2011). Para o filme polimérico contendo a carga (amostra FG-Co-S - Figura 5 b.), o perfil de absorção se mostra diferente quando comparado ao filme puro (FG). O material passa a ter absorção na região do visível, apresentando em seu espectro (Figura 5 b.) um ombro em $542 \mathrm{~nm}$, o qual é característico da carga Co-S, atestando a presença desta na matriz polimérica, o que influenciou na propriedade óptica do filme.

Os filmes FG e FG-Co-S foram submetidos ao teste de solubilidade em água e os resultados foram de 31,32 $\pm 4,65$ 
$\%$ e $9,36 \pm 3,15 \%$, respectivamente. Verifica-se que quando da presença da carga na matriz polimérica, o filme tem maior resistência à solubilidade em água nas condições empregadas.

\section{Avaliação da atividade antimicrobiana dos filmes}

Os resultados para a avaliação da inibição do crescimento das bactérias Escherichia coli e Staphylococcus aureus são mostrados na Tabela 1. A Tetraciclina foi usada como controle, a fim de comparação.

Tabela 1 - Avaliação da atividade antimicrobiana - halo de inibição (mm)

\begin{tabular}{ccc}
\hline Amostra & Escherichia coli & Staphylococcus aureus \\
\hline Tetraciclina* & $310 \pm 30$ & $435 \pm 15$ \\
FG & Não houve & $174 \pm 14$ \\
FG-Co-S & $245 \pm 45$ & $242 \pm 13$ \\
\hline
\end{tabular}

*empregada como controle

Fonte: Autores, 2018.

O filme sem carga (FG) não apresentou inibição frente a Escherichia coli enquanto que frente a Staphylococcus aureus sua inibição foi consideravelmente abaixo do antibiótico Tetraciclina. Quando da presença da carga na matriz polimérica (filme FG-Co-S) o valor do halo observado para a inibição frente a Escherichia coli está próximo ao obtido para o controle com a Tetraciclina, considerando-se os desvios padrões. Em relação à Staphylococcus aureus o compósito mostrou maior inibição que o filme FG.

Os resultados obtidos indicam uma boa atividade antimicrobiana da carga Co-S no sistema avaliado, potencializando a aplicação do filme polimérico obtido como bandagem ou até mesmo como embalagem de alimentos.

\section{CONCLUSÃO}

O presente trabalho descreveu a obtenção do salicilato de cobalto(II), por um método alternativo. A obtenção do material foi confirmada pelas técnicas de DRX e IVTF.

Quando da aplicação do salicilato de cobalto(II) (Co-S) na matriz polimérica obtida a partir da gelatina extraída das escamas de tilápia, a carga conferiu ao filme melhoras significativas nas propriedades óptica, resistência à solubilidade e atividade antimicrobiana, propriedades estas, que são de interesse tecnológico e possibilitam aplicações em diferentes áreas, destacando a produção de materiais empregados como bandagem.

\section{AGRADECIMENTOS}

À UTFPR campus Pato Branco e ao CNPq (processo 404392/2016-4).

\section{REFERÊNCIAS}

AL-SAIDI, G. S.; AL-ALAWI, A.; RAHMAN, M. S.; GUIZANI, N. Fourier transform infrared (FTIR) spectroscopic study of extracted gelatin from shaari (Lithrinus microdon) skin: Effects of extraction conditions. International Food Research Journal, v. 19, n. 3, p. 1167-1173, 2012.

ALVAREZ-ROS, M. C.; SÁNCHEZ-CORTÉS， S.; GARCÍA-RAMOS, J. V. Vibrational study of the salicylate interaction with metallic ions and surfaces. Spectrochimica Acta - Part A: Molecular and Biomolecular Spectroscopy, v. 56, n. 12, p. 2471-2477, 2000.

AVENA-BUSTILLOS, R. J.; OLSEN, C. W.; OLSON, D. A.; CHIOU, B.; YEE, E.; BECHTEL, P. J.; MCHUGH, T. $\mathrm{H}$. Water vapor permeability of mammalian and fish gelatin films. Journal of Food Science, v. 71, n. 4, p. 202 - 207, 2006.

BHAGWAT, P. K.; DANDGE, P. B. Isolation, characterization and valorizable applications of fish scale collagen in food and agriculture industries. Biocatalysis and Agricultural Biotechnology, v. 7, p. 234-240, 2016.

CHAGURI, M. P. Utilização de escamas e Eichhornia crassipes no tratamento de efluente de curtume de peles de tilápias Utilização de escamas e Eichhornia crassipes no tratamento de efluente de curtume de peles de tilápias. Disponível em: https://repositorio.unesp.br/bitstream/handle/11449/86744/c haguri_mp_me_jabo.pdf?sequence=1>. Acesso em 12 set 2018.

DAS, S. K.; BHUNIA, M. K.; SEIKH, M. M.; DUTTA, S.; BHAUMIK, A. Highly porous Co(ii)-salicylate metalorganic framework: Synthesis, characterization and magnetic properties. Dalton Transactions, v. 40, n. 12, p. 2932-2939, 2011.

DEACON, G. B.; PHILLIPS, R. J. Relationships between the carbon-oxygen stretching frequencies of carboxylato complexes and the type of carboxylate coordination. Coordination Chemistry Reviews, v. 33, n. 3, p. 227-250, 1980.

GHALY A. E.; RAMAKRISHNAN, V. V.; BROOKS M. S.; BUDGE S. M.; DAVE D. Fish Processing Wastes as a Potential Source of Proteins, Amino Acids and Oils: A Critical Review. Journal of Microbial \& Biochemical Technology, v. 05, n. 04, p. 107-129, 2013.

HUANG, C. Y.; KUO, J. M.; WU, S. J.; TSAI, H. T. Isolation and characterization of fish scale collagen from tilapia (Oreochromis sp.) by a novel extrusion-hydroextraction process. Food Chemistry, v. 190, p. 997-1006, 2016.

IMANIEH, H.; AGHAHOSSEINI, H. Synthesis and character investigation of new collagen Hydrolysate/polyvinyl alcohol/hydroxyapatite PolymerNano-Porous Membranes: I. Experimental design optimization in thermal and structural properties. Systems and Synthetic Biology, v. 7, n. 4, p. 175-184, 2013.

KISHORE， K.; NAGARAJAN， R. Structure-thermal behaviour studies on the salicylato complex of cobalt. Journal of Thermal Analysis, v. 22, n. 1, p. 25-32, 1981.

LIU, H.; HUANG, K. Structural Characteristics of Extracted Collagen from Tilapia (Oreochromis mossambicus) Bone: Effects of Ethylenediaminetetraacetic Acid Solution and Hydrochloric Acid Treatment. International Journal of Food Properties, v. 19, n. 1, p. 63-75, 2016.

MARTINS, M. E. O.; CLAUDINO, R. L.; MORAIS, J. P. S.; CASSALES, A. R.; ALEXANDRE, I. C.; SOUZA, B. W. S.; ALCÂNTARA, L. O. ; SOUSA, J. R.; SOUZA FILHO, M. S. M. Obtenção de Gelatina a partir de Escama de Tilápia (Oreochromis niloticus): Características 
Químicas e Físico-químicas. Boletim de Pesquisa Embrapa, n. 108, 2015. Disponível em: < https://ainfo.cnptia.embrapa.br/digital/bitstream/item/13724 4/1/BPD15013.pdf>. Acesso em 12 set 2018.

MERINA, P. D.; SUGUNA, P. R.; KARPURAM, P.; VIJAYLAKSHMI, J.; RENUKA, M. Extraction and characterization of gelatin: A funcional biopolymer. International Journal of Pharmacy and Pharmaceutical Sciences, v. 9, n. 9, p. 239-242, 2017.

MOHAMMAD, A. W.; KUMAR, A. G.; BASHA, R. K. Optimization of enzymatic hydrolysis of tilapia (Oreochromis Spp.) scale gelatine. International Aquatic Research, v. 7, n. 1, p. 27-39, 2014.

NAKAMOTO, K. Infrared and Raman Spectra of Inorganic and Coordination Compounds Part B: Applications in Coordination, Organometallic, and Bioinorganic Chemistry. sixth edit ed. Hoboken: John Wiley \& Sons, 2009.

NETHRAVATHI, C.; RAVISHANKAR, N.; SHIVAKUMARA, C.; RAJAMATHI, M. Nanocomposites of $\alpha$-hydroxides of nickel and cobalt by delamination and co-stacking: Enhanced stability of $\alpha$-motifs in alkaline medium and electrochemical behaviour. Journal of Power Sources, v. 172, n. 2, p. 970-974, 2007.

NOR, M. H. M.; NAZMI, N. N. M.; SARBON, N. M. Effects of plasticizer concentrations on functional properties of chicken skin gelatin films. International Food Research Journal, v. 24, n. 5, p. 1910-1918, 2017.

NURUL, A. G.; SARBON, N. M. Effects of $\mathrm{pH}$ on functional, rheological and structural properties of eel (Monopterus sp.) skin gelatin compared to bovine gelatin. International Food Research Journal, v. 22, n. 2, p. 572 $583,2015$.

PIASEK, Z.; URBANSKI, T. The Infrared Absorption Spectrum and Structure of Urea. Bulletin de L'Academie Polonaise des Scinces, Série des Sciences Chimiques, v. 10, p. 113-120, 1962.

PICKLER, E.; FILHO, J. E. R. V. Evolução Da Piscicultura No Brasil: Diagnóstico E Desenvolvimento Da Cadeia Produtiva De Tilápia. Textos para Discussão - IPEA, agosto de 2017. Disponível em: < http://www.ipea.gov.br/portal/images/stories/PDFs/TDs/td_ 2328.pdf $>$. Acesso em 12 set 2018.

PRAVEEN, K.; MADHAVI, D. S. S.; KUMAR, K. A.; KUMAR, Y. K. Coordination Chemistry of Salicylic Acid. International Journal of Engineering and Science Invention, v. 5, n. 9, p. 2319-6734, 2016.

SANTOS, E. D. B.; VIEIRA, E. F. S.; CESTARI, A. R.; BARRETO, L. S. Caracterização de escamas do peixe piau (Leporinus elongatus) e sua aplicação na remoção de $\mathrm{Cu}(\mathrm{II})$ de meio aquoso. Quimica Nova, v. 32, n. 1, p. 134-138, 2009.

SHALASH, A. M.; ABU ALI, H. I. Synthesis, crystallographic, spectroscopic studies and biological activity of new cobalt(II) complexes with bioactive mixed sulindac and nitrogen-donor ligands. Chemistry Central Journal, v. 11, n. 1, 2017.

SILVA, T. F. D.; PENNA, A. L. B. Colágeno:
Características químicas e propriedades funcionais. Revista Instituto Adolfo Lutz, v. 71, n. 3, p. 530-9, 2012.

SOCKALINGAM, K.; ABDULLAH, H. Z. Extraction and characterization of gelatin biopolymer from black tilapia (Oreochromis mossambicus) scales. AIP Conference Procedings, 2015. Disponível em: <http://aip.scitation.org/doi/abs/10.1063/1.4919191>.

TRIVEDI, M. K.; BRANTON, A.; TRIVEDI, D.; SHETTIGAR, H.; BAIRWA, K.; JANA, S. Fourier Transform Infrared and Ultraviolet-Visible Spectroscopic Characterization of Biofield Treated Salicylic Acid and Sparfloxacin. Natural Products Chemistry \& Research, v. 03, n. 05, p. 3-5, 2015.

WANG, L.; LU, S.; ZHOU, Y.; GUO, X.; LU, Y.; HE, J.; EVANS, D. G. Facile synthesis of metal-organic cobalt hydroxide nanorods exhibiting a reversible structural transition. Chemical communications (Cambridge, England), v. 47, n. 39, p. 11002-11004, 2011.

WENG, W.; ZHENG, H. Effect of transglutaminase on properties of tilapia scale gelatin films incorporated with soy protein isolate. Food Chemistry, v. 169, p. 255-260, 2015.

XIAO, C.; Lu, Y.; Jing, Z.; Zhang, L. Study on physical properties of blend films from gelatin and polyacrylamide solutions. Journal of Applied Polymer Science, v. 83, n. 5, p. 949-955, 2002.

YANG, J.; LIU, H.; MARTENS, W. N.; FROST, R. L. Synthesis and characterization of Cobalt hydroxide, cobalt oxyhydroxide, and cobalt oxide nanodiscs. Journal of Physical Chemistry C, v. 114, n. 1, p. 111-119, 2010.

\section{COPYRIGHT}

Direitos autorais: Os autores são os únicos responsáveis pelo material incluído no artigo.

Submetido em:28/09/2018 Aprovado em: 05/12/2018 


\title{
DESENVOLVIMENTO DE UM SISTEMA AUTOMATIZADO PARA ALIMENTAÇÃO DE LINHAS DE PRODUÇÃO DE RÁDIOS AUTOMOTIVOS INTRÍNSECO À INDUSTRIA 4.0
}

\author{
DEVELOPMENT OF AN AUTOMATED SYSTEM FOR POWER SUPPLY OF \\ AUTOMATIC RADIO PRODUCTION INTRINSIC TO INDUSTRY 4.0
}

\author{
ERIK TAVARES GUEDES ${ }^{1}$; MANOEL S. S. AZEVEDO ${ }^{2}$; JANDECY CABRAL LEITE ${ }^{1}$; ARLINDO \\ MESSIAS MENDES DA COSTA ${ }^{2}$; GEANNE TEREZA FERREIRA OLIMPIO ${ }^{2}$, \\ WILL RIBAMAR MENDES ALMEIDA ${ }^{3}$ \\ 1 - PPGEP/ITEC/UFPA/ITEGAM; 2 - UNIVERSIDADE DO ESTADO DO AMAZONAS (UEA); \\ 3 - UNIVERSIDADE CEUMA
}

erik.automacao@hotmail.com; mazevedo@uea.edu.br; jandecycabral@hotmail.com; ammc.eng17@uea.edu.br; geanneolimpio@hotmail.com; will75@gmail.com

\begin{abstract}
Resumo - Este artigo tem como objetivo desenvolver um sistema automatizado de linhas de produção de Rádios Automotivos intrínsecos à Indústria 4.0. A motivação principal para realização deste trabalho reside no fato da Internet permitir que os usuários acessem informação em qualquer momento e lugar. Com isso, permite que empresas, públicas ou privadas, conduzam negócios e compartilhem informações ou dados em uma base global. Para isto foi necessário o desenvolvimento de um software de supervisão de chamadas de materiais com status de cada pedido tempo da chamada e previsão de término do atendimento e alimentador responsável pelo pedido (chamado). Os resultados foram gerados automaticamente utilizando-se um leitor de código de barras para otimizar uma Empresa do Pólo Industrial de Manaus (PIM) e ao final da implementação verificou-se que proposta otimizou o tempo de execução processo fabril em $50 \%$ permitindo a redução de horas extras, dos gastos da empresa, mão-de-obra e energia elétrica, refletindo diretamente no custo de produção.
\end{abstract}

Palavras-chave: Sistema Automatizado. Indústria 4.0. Linha de Produção.

\begin{abstract}
This paper aims to develop an automated system of production lines of Automotive Radios intrinsic to Industry 4.0. The main motivation for this work comes from the fact that the Internet allows users to access information at any time and place. This allows companies, public or private, to conduct business and share information or data on a global basis. For this, it was necessary to develop a software for the supervision of materials calls with the status of each request time of the call and forecast of the termination of the service and the feeder responsible for the request (called). The results were generated automatically using a barcode reader to optimize a company in the Industrial Hub of Manaus (PIM) and at the end of the implementation, it was verified that the proposal optimized the manufacturing process time by $50 \%$, allowing the reduction of overtime, company expenses, labor and electricity, directly reflecting the cost of production.
\end{abstract}

Keywords: Automated System. Industry 4.0. Production Line.

\section{INTRODUÇÃO}

O fenômeno da Indústria 4.0 foi mencionado pela primeira vez em 2011 na Alemanha como uma proposta para o desenvolvimento de um novo conceito da política econômica alemã baseada em estratégias de alta tecnologia (ROBLEK et al., 2016).

As tecnologias de identificação por radiofrequência (RFID) desfrutam de enorme interesse no momento atual, não apenas do ponto de vista da pesquisa, mas também da prática corporativa. Empresas de diversos ramos estão esperando soluções para uma ampla gama de problemas de gerenciamento através de RFID, desde aumentos simples na eficiência de processamento para o recebimento e despacho de mercadorias nos centros de distribuição até melhorias na disponibilidade de mercadorias nas prateleiras e na luta contra a falsificação de produtos. Após muitos anos de divulgação da tecnologia, no entanto, torna-se cada vez mais evidente que a adoção real de RFID está aquém das expectativas otimistas dos primeiros anos (MATTA e MOBERG, 2006), por exemplo, afirmam que, além de toda a atenção dada à tecnologia RFID, o ritmo de adoção de RFID real ou planejado pelas empresas em suas cadeias de suprimentos permanece baixo a moderado (SCHMITT et al., 2007).

Atualmente a globalização tem como principal desafio de atender à crescente demanda mundial por capital e consumo de bens, assegurando uma evolução sustentável de forma a atender as dimensões sociais, ambientais e econômicas, ou seja, realização de manufatura sustentável. Para lidar com esse desafio, a criação de valor industrial deve ser focada na sustentabilidade. Atualmente, a criação de valor industrial nos primeiros países industrializados é moldada pelo desenvolvimento em direção à quarta etapa da industrialização, a chamada Indústria 4.0.

$\mathrm{Na}$ segunda seção deste trabalho é apresentada uma revisão sobre a Indústria $4.0 \mathrm{com}$ base nas recentes pesquisas e práticas, além de uma visão geral das 
oportunidades de manufatura sustentável oriunda da Indústria 4.0. Haverá também um caso de uso para a adaptação de equipamentos de fabricação como uma oportunidade específica para a manufatura sustentável na Indústria 4.0 (STOCK e SELIGER, 2016).

Uma visão mais abrangente do importante papel da Computação Visual como Key Enabling Technology na materialização das diferentes visões globais da nova geração de soluções de TIC na Indústria e na Indústria em geral. Uma tendência mundial nos países de manufatura avançada está definindo Industria 4.0, a Internet Industrial bem como, uma nova onda que pode revolucionar a produção e seus serviços associados, com base no surgimento da Internet das Coisas e Serviços nas fábricas, permitindo a configuração de sistemas ciberfísicos de combinação com outras tecnologiaschave. A computação visual desempenha um papel importante como "fator de adesão" em soluções completas (POSADA et al., 2015).

Segundo Bahin, (2016), a indústria 4.0 corresponde a quarta revolução industrial que foi introduzida pela primeira vez na Alemanha. Várias empresas, centros de pesquisa e universidades declaram que a robótica e a automação são a base da fabricação industrial e também um importante direcionador para a Indústria 4.0. Permitiu-se que, a partir deste trabalho, estudantes de engenharia sejam expostos a novas invenções de revolução tecnológica, bem como criar a mente de negócios para um futuro melhor (BAHRIN et al., 2016).

Recentemente ocorreram muitos avanços nas tecnologias de comunicação sem fio, mais precisamente na área de redes de sensores sem fio. Estas passaram por um rápido desenvolvimento tecnologico e foram largamante aplicadas com sucesso no mercado de eletrônicos de consumo. Diante disso, percebeu-se que as redes sem fio (WNs) atraim mais atenção das comunidades acadêmicas e de outros domínios. Do ponto de vista industrial, os WNs apresentam muitas vantagens, dentre elas: flexibilidade, baixo custo, fácil implantação e baixa manutenção. Portanto, os WNs podem desempenhar um papel vital na estrutura do Industria 4.0 fomentando para fábricas inteligentes e sistemas inteligentes de manufatura.

Neste artigo, é apresentada uma visão geral dos WNs industriais (IWNs), discutindo seus recursos e as técnicas relacionadas e, em seguida, apresentou-se uma nova arquitetura baseada na qualidade do serviço e na qualidade dos dados para os IWNs. Também foi proposto algumas aplicações para os padrões IWNs e IWN. Em seguida, utilizou-se um caso prático para explicar como projetar um IWN na Indústria 4.0. Finalmente, destacamse alguns dos desafios de design e de questões abertas que ainda necessitam ser abordadas para tornar os IWNs realmente onipresentes para uma ampla gama de aplicações (LI et al., 2017).

Hoje, a Ethernet em Tempo-Real (RTE) se tornou um padrão no domínio de automação industrial. Infelizmente, não há atualmente um padrão único, mas muitas implementações mutuamente incompatíveis. As soluções RTE existentes são baseadas em Fast Ethernet e podem ser divididas em três classes, que diferem no desempenho em tempo real alcançado e nas extensões necessárias dos padrões IEEE 802 (WOLLSCHLAEGER et al., 2017).

\section{A AUTOMAÇÃO NA INDUSTRIA 4.0}

A situação da economia mundial urge por soluções emergentes e imediatas para se resolver problemas de automação que possibilitem alavancar a produção de vários produtos, desde a agricultura, bem como, linhas de produção industrial nos vários tipos de produtos que são fabricados. Então sistemas de automação apoiadas nas tomadas de decisões e que faz um setup automático das variáveis de controle de produção, alterando parâmetros dos Controladores Lógicos Programáveis (CLPs) ou DCS, puxando a produção para contingenciar as chuvas previstas, direciona o aumento da produção por exemplo, de $10 \%$ de etanol sob contrato de governo brasileiro, direciona caldo primário para elevação de produção de açúcar visto elevação do preço da oferta, contingencia compra de insumos de fornecedor alternativo, faz uma parada programada para manutenção baseada em eventos, contingenciada para suportar a demanda, numa eventual chuva já prevista, essas decisões foram tomadas, todas de forma automática, baseada num banco de dados Big Data. Essa é a indústria do futuro, essa é a Indústria 4.0 (JAIMES et al., 2017).

Para Venturelli (2014), a Internet das Coisas (IoT) na indústria, refere-se a um ambiente em que todos os equipamentos e máquinas estão conectadas em redes e que disponibilizam informações de forma única. $\mathrm{O}$ mesmo autor ainda reforça informando esmo a Indústria 4.0 sendo ainda mais um conceito do que uma realidade, ela está sendo motivada por três grandes mudanças no mundo industrial produtivo:

- Avanço exponencial da capacidade dos computadores;

- Imensa quantidade de informação digitalizada;

- Novas estratégias de inovação (pessoas, pesquisa e tecnologia).

Para Azevedo (2017) a Indústria 4.0 como uma evolução dos sistemas produtivos industriais, sendo" caracterizada pelo "uso intensivo de tecnologias digitais com o intuito de fabricar novos produtos de forma rápida, com uma ágil resposta à demanda e otimização em tempo real da produção e da cadeia de suprimentos" (AZEVEDO, 2017, p. 20). Este mesmo autor, em sua tese de doutorado, página 53, ainda corrobora listando alguns benéficos previstos e baseados no impacto nas fábricas industriais, inclusive ao PIM:

- Redução de Custos;

- Economia de Energia;

- Aumento da Segurança;

- Conservação Ambiental;

- Redução de Erros;

- Fim do Desperdício;

- Transparência nos Negócios;

- Aumento da Qualidade de Vida;

- Personalização e Escala sem Precedentes.

Assim, essa tecnologia de base é responsável por este conceito é o IoT e o M2M - Machine to Machine (Máquina para Máquina). A Internet das Coisas, permite a conexão lógica de todos os dispositivos e meios relacionados ao ambiente produtivo em questão, os sensores, transmissores, computadores, células de 
produção, sistema de planejamento produtivo, diretrizeß estratégicas da indústria, informações de governo, clima, fornecedores, tudo sendo gravado e analisado em um banco de dados. A ideia de Máquina para Máquina é a interconexão entre células de produção, os sistemas passam a trocar informações entre si, de forma autônoma, tomando decisões de produção, custo, contingencia, segurança, através de um modelo de inteligência artificial, complementado pela IoT.

De acordo com Tassi (2017), isso só é possível com convergência destes dois mundos, o surgimento de novas Tecnologias da Informação (TI) aplicadas a Automação Industrial. A mesma autora corrobora citando as principais tecnologias, como segue:

- Protocolo IPV6 (ampliação dos pontos de conexão IP de todos Devices);

- Wireless (ampla utilização de redes sem fio);

- Virtualização (criação de diversos computadores a partir de softwares);

- Cloud (as informações estarão na Nuvem compartilhada)

- Big Data (todas as informações reunidas, de forma dinâmica para tomada de decisões);

- RFID (todo movimento de materiais é rastreado com todas as informações).

A partir das principais tecnologias citadas, percebese que haverá uma nova realidade produtiva, tudo estará conectado para que as melhores decisões de produção, custo e segurança sejam tomadas, tudo sob demanda e em tempo real (SOUZA, 2016).

Atualmente, vive-se uma transição entre a Terceira e a Quarta Revolução Industrial, a Indústria 4.0 e, para que se estabeleça um caminho para a implantação, é importante entender este momento em que os sistemas de automação devem estar orientados a aumento da produção, redução de custos e visão nas mudanças tecnológicas. Assim, a plataforma técnica deve estar estruturada com redes industriais, sistemas de otimização e banco de dados (PEREIRA e DE OLIVEIRA SIMONETTO, 2018).

Entendendo que a partir do uso das premissas anteriores, o amadurecimento operacional, levará a esta nova demanda, em que a visão da Indústria 4.0 estará orientada a eficiência energética, integração da cadeira produtiva e orientação produtiva via Business Intelligence (BI), onde a estruturação técnica levará ao controle de processos descentralizado, todos os ativos estarão on-line e as tomadas de decisões serão baseadas no Big Data (YOON et al., 2014).

De acordo com Venturelli (2014), a Indústria 4.0, a partir do momento atual, remete-se a entender sua tendência no meio produtivo e propõe-se a observar as seguintes tendências que já estão em movimento no meio industrial:

- Interconexão "Das Coisas" numa Única Rede (Internet) através do IPv6 na Nuvem - Cloud;

- Geração, envio, acúmulo e análise de dados no Big Data - modelagem para tomada de decisões autônomas;

- Onipresença da Informação, não importa onde você esteja, a interação é em tempo real. mesmo autor ainda corrobora afirmando que a Indústria 4.0 é um novo conceito que seguramente será uma realidade, mudará a forma como lidar hoje com a produção de bens de consumo e materiais, tendo uma melhor distribuição de riquezas e um planeta mais sustentável.

\section{MATERIAIS E MÉTODOS}

Para aprimorar o funcionamento da linha de produção, foi implementado o projeto de automação da seção da linha de uma fábrica, sendo esta modernização aplicada na etapa de alimentação, com a finalidade, deste sistema integrado, determinar e informar o tipo de material ou peça que devem ser inseridos na linha, evitando possíveis adversidades, como contratempos gerados por parada na produção, por falta de alimentação da linha, e por conseguinte, resultando na criação de um gargalo na produção.

$\mathrm{O}$ projeto foi subdividido em hardware (componentes utilizados) e software (programa com interface gráfica). Primeiramente, a seção correspondente ao software foi desenvolvida definindo-se uma interface gráfica, que realiza interações com os operadores da linha, solicitando pelo painel interligado entre diferentes setores, o material ou peça a ser inserido naquela linha, por meio de um leitor de código de barras, para que o pedido seja realizado com eficiência, depois de inserida um senha de autorização para liberação do material, pode-se seguir para uma tela de status que apresentará por meio da identificação do funcionário, quem será o alimentador.

Num segundo momento, já interligando a seção de software com a de hardware, os painéis de exibição da conjuntura da seção de alimentação estão incluídos, também incorporando ao sistema, o espelhamento da aplicação por meio do programa Virtual Network Computing -VNC viewer, protocolo que permite controlar remotamente um computador por meio de uma interface gráfica, sendo o mesmo utilizado na sala denominada "supermarket", nesta, após a solicitação explícita no painel, o funcionário deve acionar os botões de status na tela para que as linhas que almejam a alimentação estejam iteradas, e logo, os materiais solicitados sejam deslocados para as mesmas, abastecendo-as.

Finalmente, essa solicitação realizada de forma automatizada, substitui o uso um tanto obsoleto de rádios de comunicação, que muitas das vezes apresentavam interferências no sinal, gerando falhas na interlocução dos responsáveis, e por consequência, um gargalo na produção, devido à alimentação ineficiente dessas mesmas linhas. O diagrama ilustrado na figura 1, demonstra o funcionamento do sistema proposto. 


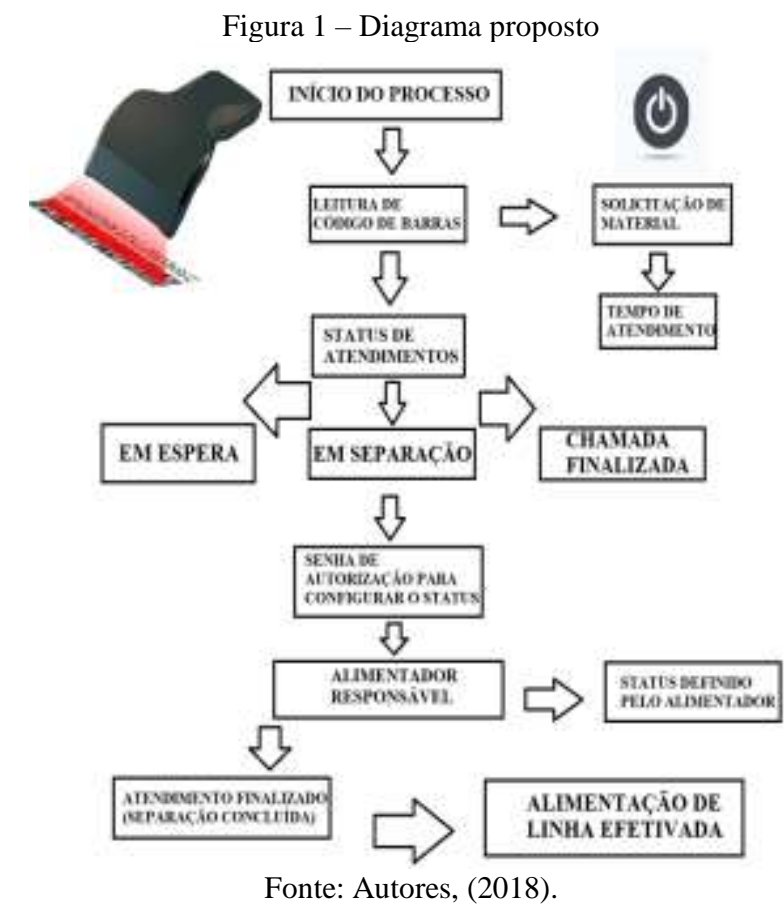

\section{RESULTADOS}

O sistema automatizado foi implementado em uma linha de produção de uma Empresa do PIM, objetivando um aperfeiçoamento no funcionamento da mesma. O sistema que inicia com a solicitação do material por meio do código de barras e, por conseguinte, a configuração do status do atendimento, indicando no painel, logo, em seguida, o alimentador responsável e o status de progresso, até o momento em que o material chegue até a linha para dar continuidade ao processo produtivo, como já foi exposto anteriormente, no diagrama de blocos do processo. Apresentou-se, portanto, as seguintes melhorias:

- Diminuição do tempo de atendimento - Antes da implementação, a comunicação e solicitação do material eram realizadas via rádio entre os setores, de modo que o tempo se encontrava aumentado, devido ao deslocamento e ineficiência no ato da solicitação;

- Maior controle sob o atendimento - Anteriormente não havia monitoramento desde o início, cronometrando o tempo até a finalização da solicitação, permitindo alterações de forma positiva em linhas de produção que estão obtendo níveis baixos de produtividade, devido aos atrasos, gerando gargalos.

A solicitação, em média, demorava aproximadamente 40 minutos para a finalização, e após a implementação do sistema proposto, obteve-se um tempo de execução de 20 a 25 minutos. Permitindo reduzir de 25 a $50 \%$ o tempo de execução da linha de produção em análise, conforme resultados apresentados na tabela 1 .

Tabela 1 - Resultados antes e depois da implementação

\begin{tabular}{ccc}
\hline $\begin{array}{c}\text { Status de } \\
\text { implementação }\end{array}$ & $\begin{array}{c}\text { Tempo de } \\
\text { duração }\end{array}$ & Resultados \\
\hline Não implementada & 40 min & Redução entre 25 \\
Implementada & 20 a 25 min & $\begin{array}{c}\% \text { a 50\% do } \\
\text { tempo de } \\
\end{array}$ \\
& & execução \\
\hline
\end{tabular}

Segundo a tabela 1, observa-se que a implementação do projeto otimizou o processo, devido à essa redução no tempo de espera e ainda, devido às algumas paradas na linha de produção causadas pela falta de alimentação, foi possível também, reduzir horas extras e consequentemente, diminuindo os gastos da empresa, com a mão-de-obra e ainda com o consumo de energia elétrica, refletindo diretamente no custo de produção, e ocasionando a redução do mesmo.

\section{CONCLUSÃO}

O presente trabalho apresentou a implementação e a implantação de um sistema automatizado em uma linha de produção de uma Empresa do Pólo Industrial de Manaus que otimizou o funcionamento da mesma, considerado um projeto de inovação de sistemas automatizados e integrados de manufatura. A integração das etapas de simulação e implementação permitiram uma maior confiabilidade na validação, otimização e realização da estrutura de controle. Foi constatado que os procedimentos desenvolvidos e efetuados se mostraram eficazes, obtendo redução do tempo de execução dos processos industriais, redução dos gastos da empresa quanto a mão-de-obra e energia elétrica, refletindo diretamente no custo de produção e nos gastos da empresa.

Essa forma de automação da fábrica com a troca de dados aumenta a produtividade do processo e isso está relacionado com a Indústria 4.0, que de forma geral, busca formar "fábricas inteligentes". É necessário interligar toda a empresa com essa troca de informações em tempo real, afim de que se tenha uma melhor visualização do funcionamento da empresa, com a oportunidade de agregar um maior valor aos clientes, entretanto, se não houver enfoque adequado, isso poderá não trazer os resultados esperados.

Assim sendo, este trabalho teve sua importância do ponto de vista científico, pois, retrata a interligação de um sistema de automação com a indústria 4.0, refletindo sua importância para o futuro de empresas que desejam se encaixar nessa nova forma de negócio que está crescendo nos últimos anos.

\section{REFERÊNCIAS}

AZEVEDO, M. T. de. Transformação digital na indústria: indústria 4.0 e a rede de água inteligente no Brasil. Tese de Doutorado em Engenharia Elétrica . Escola Politécnica da Universidade de São Paulo. 2017

BAHRIN, M. A. K. et al. Industry 4.0: A review on industrial automation and robotic. Jurnal Teknologi, v. 78, n. 6-13, p. 137-143, 2016.

JAIMES, C. I. R. et al. Modelo de integração para inspeção em malha fechada aderente a STEP-NC. Anais do IX Congresso Brasileiro de Engenharia de Fabricação. ABCM, 2017.

LI, X. et al. A review of industrial wireless networks in the context of industry 4.0. Wireless networks, v. 23, n. 1, p. 23-41, 2017. ISSN 1022-0038.

MATTA, V.; MOBERG, C. The development of a research agenda for RFID adoption and effectiveness in supply chains. Issues in Information Systems, v. 7, n. 2, p. 246-251, 2006. 
PEREIRA, A.; DE OLIVEIRA SIMONETTO, E. Indústria 4.0: conceitos e perspectivas para o brasil. Revista da Universidade Vale do Rio Verde, v. 16, n. 1, 2018. ISSN 2236-5362.

POSADA, J. et al. Visual computing as a key enabling technology for industrie 4.0 and industrial internet. IEEE computer graphics and applications, v. 35, n. 2, p. 26-40, 2015. ISSN 0272-1716.

ROBLEK, V.; MEŠKO, M.; KRAPEŽ, A. A complex view of industry 4.0. Sage Open, v. 6, n. 2, p. 2158244016653987, 2016. ISSN 2158-2440.

SCHMITT, P.; THIESSE, F.; FLEISCH, E. Adoption and diffusion of RFID technology in the automotive industry. Proceedings of the 15th European conference on information systems, 2007.

SOUZA, N. S. D. Uma visão geral sobre a internet das coisas e suas aplicações. 2016.

STOCK, T.; SELIGER, G. Opportunities of sustainable manufacturing in industry 4.0. Procedia Cirp, v. 40, p. 536541, 2016. ISSN 2212-8271.

TASSI, F. R. A influência do Iot na indústria: rumo à indústria 4.0. Monografia apresentada ao Curso de Ciências Econômicas da Universidade Federal do Paraná. 2017.

VENTURELLI, M. Automação Industrial. Indústria 4.0: Uma Visão da Automação Industrial. 2014. Disponível em: <http://www.automacaoindustrial.info/industria-4-0-umavisao-da-automacao-industrial/>. Acesso em: 11. set. 2018.

WOLLSCHLAEGER, M.; SAUTER, T.; JASPERNEITE, J. The future of industrial communication: Automation networks in the era of the internet of things and industry 4.0. IEEE Industrial Electronics Magazine, v. 11, n. 1, p. 1727, 2017. ISSN 1932-4529.

YOON, T. E.; GHOSH, B.; JEONG, B.-K. User acceptance of business intelligence (BI) application: Technology, individual difference, social influence, and situational constraints. System Sciences (HICSS), 2014 47th Hawaii International Conference on, 2014, IEEE. p.3758-3766.

\section{COPYRIGHT}

Direitos autorais: Os autores são os únicos responsáveis pelo material incluído no artigo. 
VIABILIDADE DE APLICAÇÃO DE ENERGIA SOLAR PARA GERAÇÃO DE ENERGIA E AQUECIMENTO DE ÁGUA

\author{
FEASIBILITY APPLICATION OF SOLAR ENERGY FOR POWER GENERATION \\ AND WATER HEATING
}

\author{
FERNANDO DA COSTA LIMA ${ }^{1}$; TEOFILO MIGUEL DE SOUZA ${ }^{1}$; STEPHANIE CAROLINE MACHADO \\ THOMAZ DA SILVA LIMA ${ }^{1}$; PEDRO MAGALHÃES SOBRINHO ${ }^{1}$ \\ 1 - UNESP - GUARATINGUETÁ \\ fcoslima@yahoo.com.br; teofilo@feg.unesp.br; stephaniethomaz@yahoo.com.br; sobrinho@feg.unesp.br
}

\begin{abstract}
Resumo - Este artigo avalia o estado da arte referente ao desenvolvimento da energia solar e aplicações recentes. Pode ser concluído que há um aumento na eficiência devido a pressões externas e organizações ambientais. Combustiveis fósseis precisam ser substituídos em breve para evitar uma falta destes recursos. Muitas questões desafiadoras estão em pauta para tornar viável baseado nos seguintes tópicos: como armazenar a energia dos paineis solares, a melhor arquitetura: isolada ou conectada a rede, como adequar o arranjo dos paineis de modo a conseguir a maior incidência, como fazer desenvolvimentos de pequena escala utilizados para prova de conceito se tornarem viáveis para aplicações de grande escala e onde são as áreas com maior incidência solar. Os resultados são promissores $e$ necessitarão de tempo de investimento e dinheiro com apoio do governo para estimular a multiplicação da tecnologia ao longo do mundo.
\end{abstract}

Keywords: Energia Solar. Energia de Aquecimento. Sustentabilidade.

Abstract - This paper aims to evaluate the state of art regarding solar energy development and recent applications. It can be evaluated that there is an increase on efficiency development due to the external pressure from governments and environmental organizations. Fossil fuels need to be replaced in a near future to avoid a complete lack of resources. Many challenged questions are in place to make it feasible based on the following topics: how to storage the energy that comes from the solar panels, what is the best architecture: isolated or connected to the network, how to arrange the solar panels to get the highest solar incidence, how to make small-scale developments to proof of concept become feasible for large-scale applications and where are the regions with high solar incidence. The results are promising, and it will be needed to invest time and money with a government support to encourage the technology's spread around the world.

Keywords: Solar energy. Heat. Power. Sustainability

\section{INTRODUCTION}

There is a concern regarding the world source of energy. Approximately, $80 \%$ of the world energy comes from fossil fuels and it tends to increase (ALMARSHOUD and ADAM 2018; BELLOS and TZIVANIDIS, 2018). The use of renewable energies will balance the effects on the relationship between economic development and environmental problems, once as much development is needed, more energy is used and more environmental problems will be faced (BAKIRCI 2017; CHEN et al. 2017; CHIRINO et al. 2018; ERRAISSI et al. 2018).

The proposals for a new policies will be necessary in order to make consumers aware of the benefits of renewable energy use instead of fossil fuels. The moral conscience should be necessary to change consumers mind and improve the renewable energy appeal based on sustainability. It is known that at the beginning it should be harder to be feasible due to the low demand, but the benefits will overcome with the use increase (ELMUSTAPHA, HOPPE, and BRESSERS, 2018). See below the Brazilian Energy Matrix since 1971 to 2013 (FERREIRA et al. 2018):

Figure 1 - Brazil's Energy Matrix

Consumption per source - $\%$

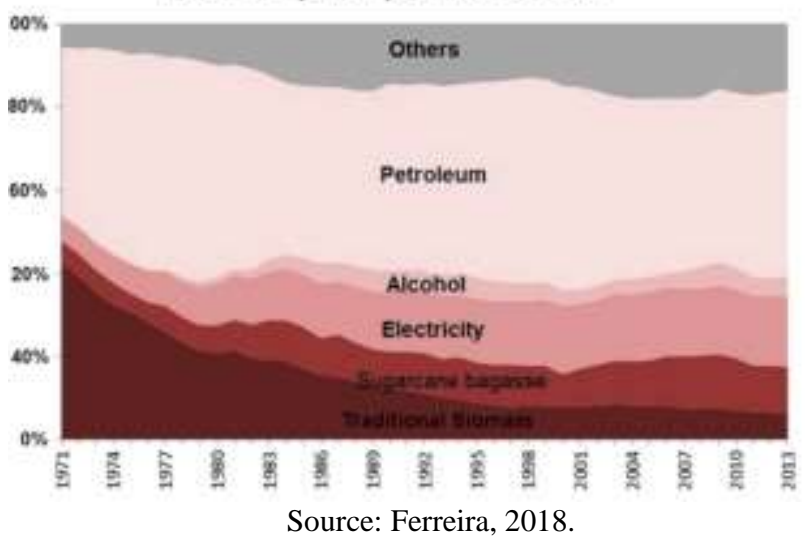

In Brazil, sugarcane is the raw material for sugarcane bagasse and Alcohol. Sugarcane is not used only for alcohol production, but also sugar. Depending on the seasonal prices, the alcohol/sugar plants can change from one product to the other. As alcohol remains in a linear base since 1983, and it was developed to supply the petroleum crisis that happened on 1970's decade, the sugarcane bagasse has an increase since 2000. That happened due to the necessity of alcohol mixture on regular gasoline according to Brazilian law and the sugar production. It is no possible to have a linear relation between sugarcane bagasse and alcohol.

That pursuit for a new sources of energy has proposed a new adaptation on existing grid power lines (CERINO ABDIN and NOUSSAN, 2018). Besides the adaptations, 
there are technical challenges to connect isolated stations to the grid line and the costs are high (ERRAISSI et al. 2018). Once there are no regular productions due to the weather conditions and the consumption behavior, it may be necessary to adapt multigeneration system to keep the output energy regular, like wind energy operating at the same place to supplement the required energy (ISLAM, DINCER, and YILBAS 2018). At the end, the existing grid lines need to be prepared to receive the exceeded production from a renewable source of energies and make it available to the complete grid network. It is particularly challenging on isolated areas that are far away from grid power lines (CERINO ABDIN and NOUSSAN 2018).

It is not only the issues related to environmental problems that drive the development for a new alternatives, it is relevant to notice that fossil fuels have limited sources and it will be more expanse and harder to find in the near future (BALALI et al. 2017; CERINO ABDIN and NOUSSAN 2018; CHENG et al. 2018). It is expected to increase the energy consumption in 44\% from 2006 to 2030 (GONZALEZ, GRÁGEDA, AND USHAK, 2017). There are some environmental friendly alternatives to fossil fuels that are abundant, like solar energy, wind energy and biomass (BELLOS and TZIVANIDIS, 2018; CIAMPI, ROSATO and SIBILIO, 2018; FERTAHI et al. 2018; ISLAM et al. 2018). In some cases it can be used as an alternative to reduce the fossil fuel consumption and in other cases those natural resources could be the only choice for rural areas, for example (WaNG, GUAN and WU 2017).

Solar energy is a clean and world available source of energy and it probably is one of the most abundant sources in the world (ALMARSHOUD and ADAM, 2018; BAKIRCI, 2017; EBRAHIMI, ARAMESH and KHANJARI, 2018). Before it goes to a large-scale production, it is necessary to mention that some proof of concepts are validated on small scales, like cooking activities (KYLILI et al. 2018). In some situations, it is used as an alternative to the regular fossil fuels and in other cases as the unique option for isolated communities (COCCIA et al. 2017).

There are two main technologies related to solar energy generation: Photovoltaic and Concentrated Solar Thermal Power. From 2016 to 2018, the last one is on the researchers' focus because it can still produce energy during the night, depending on the efficiency of the thermal energy storage (CHIRINO et al. 2018). Some advanced studies show that a combination of both technologies can also be efficient to produce either electricity and thermal energy (Ebrahimi et al. 2018).

Once solar energy is available only during the day, researches have been challenged to develop a feasible alternative to acquire and storage the thermal energy that comes from the sun in the last years (ABDULLA and REDDY 2017; CERINO ABDIN and NOUSSAN 2018; CHEN et al. 2017) and most of the technologies are based on reversible chemical reactions (CHEN et al. 2018). It will, for sure, spread the use of that kind of technology on energy generation (ABDULLA and REDDY 2017; AGALIT, ZARI and MAAROUFI, 2017). In Iran, for example, it has been a pressure from the government to guarantee the energy sustainability for the next generations and be less dependent from fossil sources of energy (AGHAHOSSEINI et al. 2017).
One of the most improved technology to solar energy storage is based on molten salts, that can include sulfates, nitrates and fluorides, due to their stability (CHEN et al. 2017), but there is a lack of techno-economic feasibility due to the restrictions on system operation temperatures and the cost of molten salts (AGALIT et al. 2017; CHEN et al. 2017). That is an evolution from Calcium-Looping process that was investigate by end of 70's for that purpose, but nowadays the molten salts are more efficient. In 2018, Calcium-Looping it is most used for $\mathrm{CO} 2$ fossil fuel capture (BENITEZ-GUERRERO et al. 2018).

The photovoltaic cell has been used for many years as solar energy capture is becoming more popular and feasible due to the high demand, especially due to public policies (CERINO ABDIN and NOUSSAN 2018; FERREIRA et al. 2018). Even for regions where the solar incidence is not so frequent during the year, that kind of technology has been shown as a viable alternative (ANDENÆS et al. 2018).

Another tricky question regarding solar energy is the location where it should be acquired. There is a divergence between the best locations for energy availability and final consumers. Almost $46 \%$ of total energy in 2012 was used for heating and cooling, it means that the energy may remain available for a long period of time including summer and winter (CIAMPI et al. 2018). That shows how significant is the demand for that kind of energy and how it affects the primary source of energy based on fossil fuels that contribute to the air pollution and global warming (EISAVI, KHALILARYA and CHITSAZ 2018).

The main objective of this paper is to identify the benefits of solar energy use on power generation and heating. A feasibility study to evaluate the technology forecast for the next 20 years and how sustainable the implementation can be done. The power generation still have some problems regarding energy storage and solar heating does not have efficient panels, but this scenario can change in the near future based on the investments promoted by governmental organizations.

\section{MODELING}

There are many success cases that were taken on developed and developing countries, such as Spain, Brazil, Marroc and Iran. Most of them showed how feasible a solar energy system can be. The use of that technology will depend on each case and a previous study should be in place in order to achieve the best results. The studies were performed in countries located on equatorial and tropical areas, where the solar incidence is higher and are more propitious for success cases.

Basically, the solar system as source of energy can be separated in five groups (FERREIRA et al. 2018):

- Connected to the network: the solar panels convert the energy and make it available on the network. No battery is needed;

- Isolated: that architecture is used when it is installed on isolated areas, like rural areas, and there is no other source of energy. A battery is needed to guarantee energy at night and when the environmental conditions are not propitious;

- Hybrid: Solar energy is combined with another source of energy, that could be renewable or not. Considering that, the energy 
should be available for more time. It can be or not connected to the network;

- Solar power plants: a huge concentration of energy source. It is connected to the network;

- Applied in consumers goods: the solar energy is embedded in the product, like calculators and watches.

Another solar energy application is related to hot water system, which can be based in two concepts (FERTAHI et al. 2018):

- Individual systems: most of the times used for single homes;

- Collective systems: defined to be used on buildings where a dynamic operation can be configured according to the family's particularities.

Figure 2 - Collective solar scheme

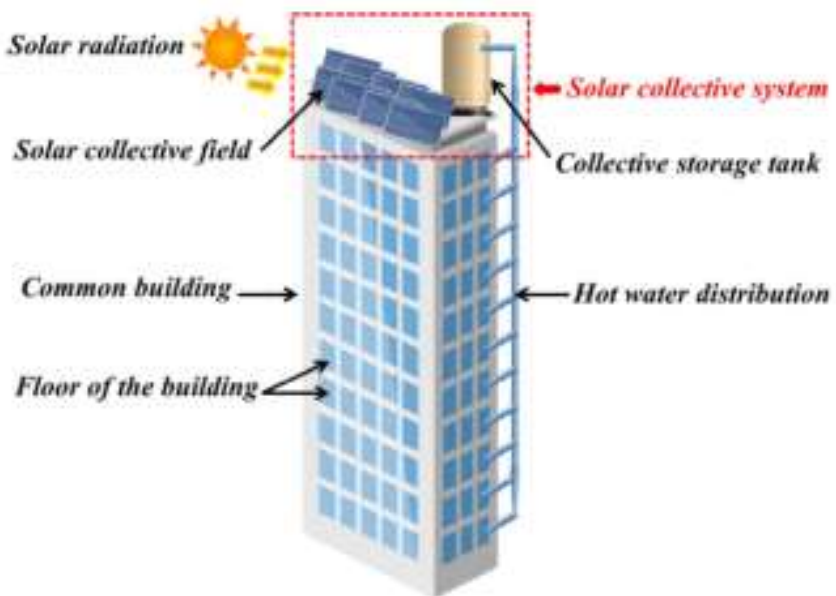

Source: Fertahi, 2017.

It is extremely important to accurate define the position of solar panels to acquire as most solar energy as possible. The angle of incidence should be evaluated to collect energy and avoid heat loses due to thermal effects. Furthermore, once there is no daily regular consumption of hot water, but a pattern can be defined to calculate the required area for panels installation and the system characteristics, like water storage. A special attention should be in place for countries far away from Equator Line due to the relevant variation on solar incidence during summer and winter times. On the graphic from Figure 3 it would be clear how a heat demand happens in UK during the day (MA, BAO, and ROSKILLY 2018).

Figure 3 - UK Daily water consumption Water consumption distribution during the day (\%)

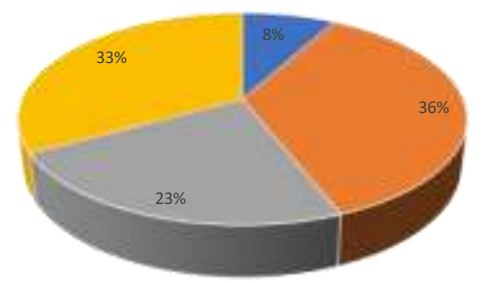

Source: Ma, 2017.
Automation systems can also be connected to the solar panels to improve the efficiency. In that case, the panels will track the sun during the day, from the sunshine to the sunset. Particularly recommended on cloudy days, where the energy acquirement can be improved with significant results due to the static systems limitations. Part of the energy generated is used for the tracking system consumption and it is still feasible on the final balance (ELDIN, ABD-ELHADY and KANDIL, 2016).

Figure 4 - Automation system to solar energy track

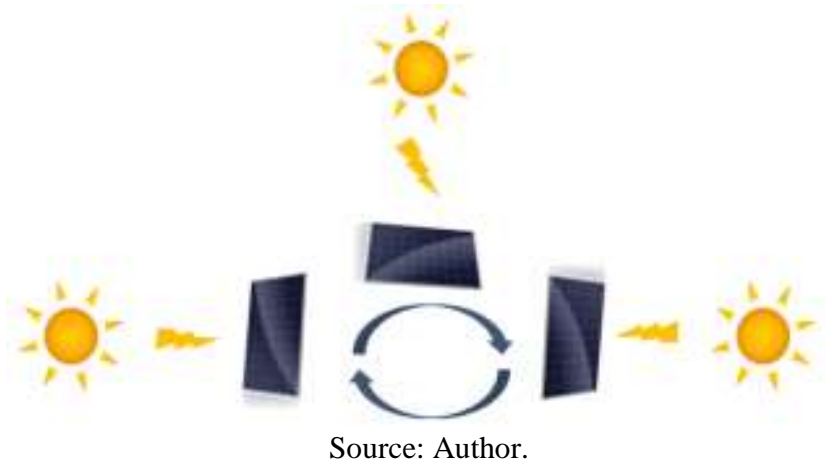

The use of that technologies and applications will drastically reduce the costs of development and raw material due to the large-scale applicability. As it was noticed in Europe, as much as new applications appear, more efficient it will be (FERREIRA et al. 2018):

Figure 5 - Europe learning curve for photovoltaic energy

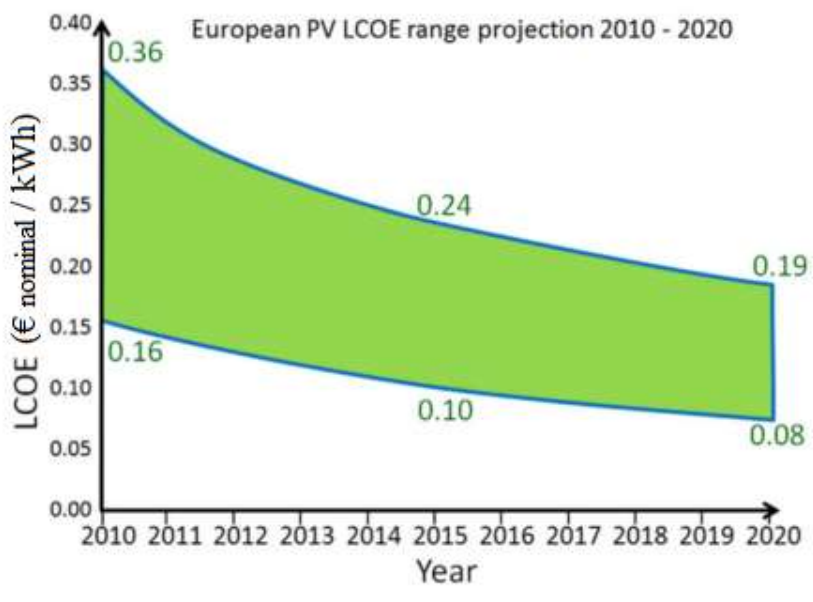

Source: Ferreira, 2018.

\section{RESULTS}

It was possible to evaluate that the most relevant success cases were developed on equatorial and tropical countries, where the solar incidence is higher than in the regions close to the poles. Those areas have a higher potential for solar technology improvements due to the propitious environmental conditions (FERREIRA et al. 2018). Even some areas have not a regular solar incidence during the year, it makes feasible during the period of the year that the related region receives regular solar incidence (MA et al. 2018).

The development and applications emerge from the small-scale studies, for example, home and small buildings. After the proof of concept, cases of feasibility are challenged to be applied on industrial cases, where the 
economic and environmental savings are even higher due to the large-scale.

There are incentives from many sources, but it has noticed that in developed countries the government has introduced many benefits that motivated the application of solar energy. In underdeveloped countries, the main initiatives are related to isolated regions, where the power network is not available and solar energy was studied as the unique option. Most of the projects are not connected to the power network. For isolated areas, the applications of solar energy are used for electric power and heating (FERREIRA et al. 2018).

Even in developed countries there is a concern regarding the energy consumption in order to reduce production costs and makes companies increase their competitiveness. That large-scale application helped to reduce the implementation costs and make it feasible for most varies situations (FERREIRA et al. 2018).

It is known that the solar panels have increased their efficiency since the first development and it has created an idea that a large space is required in order to get more power. A result from solar panels used to heat water showed that high concentration of solar panels may not increase the performance of the entire system in a linear way. It shall be studied before the solar incidence and the available area in avoid waste of investment (FERTAHI et al. 2018):

Figure 6 - Solar performance compared to different arranges

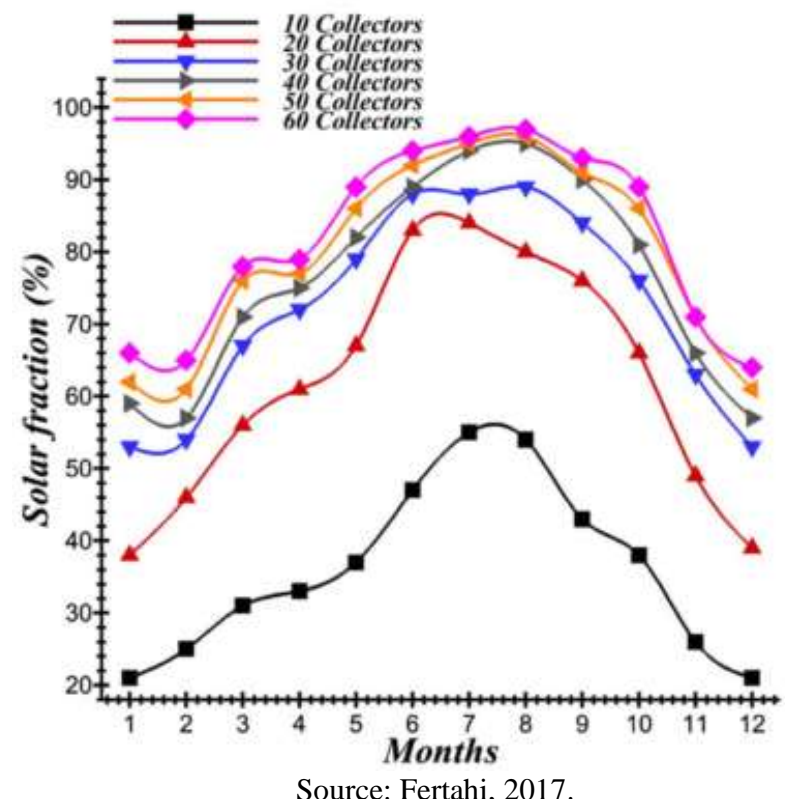

At the same time, in the desert areas where the solar incidence is high and water resources are low, it was proven that large scale photovoltaic center is feasible due to factors like (ALMARSHOUD and ADAM 2018):

- Avoid fossil fuels consumption;

- Technology is well developed and can be easily transferred to new centers;

- New job creations considering the entire work chain from the creation until the plant operation;

- Sustainable development. The solar energy on the desert provide enough electrical power for underground water pumping;

- As a desert region, water is a rare resource. During the fossil fuels extraction, it is necessary a large quantity of water. Using solar incidence, it will reduce that resource consumption.

The results demonstrate that solar energy is increasing the relevance on the energy matrix around the world and the forecast for the next 20 years are optimistic that renewable energies will receive a large investment to make it even more relevant. The grow is substantial compared to fossil fuels (INTERNATIONAL ENERGY AGENCY (IEA), 2017).

Figure 7 - International Energy Agency forecast for capacity additions

Global average aninual net capacity additions by type

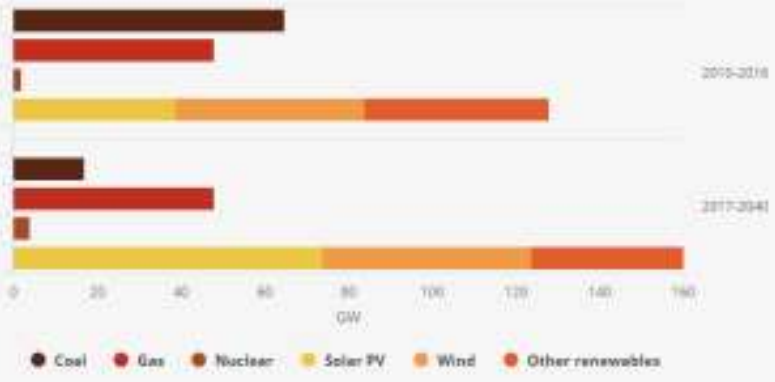

Source: IEA, 2017.

There is a great perspective for solar energy use based on the shown results. It is relevant to notice that it is still need some development on panels efficiency to reduce the installed area because a higher number of equipment does not mean more solar power absorption, it is not a linear relation between those factors. It is necessary to increase the solar power conversion to heat or power and the researches show that it may happen in the near future.

\section{CONCLUSIONS}

Based on the results collected, it was verified that solar energy has a great potential to the next 20 years, where it is expected an increase on the technology development and use. Even more the environmental organizations aim to encourage governments and private institutions to save emissions based on fossil fuels. That is an already know damage to the planet and it should be avoided before achieving irreversible levels in a near future.

The two more important outputs from solar energy are power generation and heating. In both cases the solutions have success cases that allow large-scale application after a careful study to evaluate the regions characteristics.

Regarding power generation, there are still some concerns related to the best alternative for operations conditions. Energy storage is still a challenge because there are some storage technologies that are not well developed, and it includes that they are not feasible yet. Considering that point, a network connection would help to make it feasible due to the case that the non-consumed power would be available to other regions through that connection. That's an alternative for solar photovoltaic stations that are close to the main centers and power lines, but it would be a challenge for isolated regions where the unique source of energy are the solar photovoltaic stations. Specially in those cases, the energy waste that is not storage, has a great potential of study.

The heating systems based on solar incidence are easier to manage once it depends on regular equipment acquisition to keep heating inside the consumption circuit. 
In that case the more important point is to observe the installation solar incidence and identify how to take advantage of the sun position during the day. Automation basic systems can be applied to improve the solar incidence acquisition. Another topic is related to solar panels concentration in an area once there is a non-linear relation between the number of panels and heating efficiency.

\section{REFERENCES}

ABDULLA, Ajas and REDDY, K. S. Effect of Operating Parameters on Thermal Performance of Molten Salt PackedBed Thermocline Thermal Energy Storage System for Concentrating Solar Power Plants. International Journal of Thermal Sciences, 121:30-44, 2017.

AGALIT, H.; ZARI, N. and MAAROUFI, M. Thermophysical and Chemical Characterization of Induction Furnace Slags for High Temperature Thermal Energy Storage in Solar Tower Plants. Solar Energy Materials and Solar Cells, 172(July):168-76, 2017.

AGHAHOSSEINI, A.; BOGDANOV, D.; GHORBANI, N. and BREYER, C. Analysis of $100 \%$ Renewable Energy for Iran in 2030: Integrating Solar PV, Wind Energy and Storage. International Journal of Environmental Science and Technology, 15(1):17-36, 2017.

ALMARSHOUD, A. F. and ADAM, Elfadil. Towards VLSPV Deployment in Saudi Arabia: Challenges, Opportunities and Recommendations. Energy Policy, 114 (September 2017):422-30, 2018.

ANDENÆS, Erlend et al. The Influence of Snow and Ice Coverage on the Energy Generation from Photovoltaic Solar Cells. Solar Energy, 159 (September 2017):318-28, 2018.

BAKIRCI, Kadir. Investigation of Solar Energy Potential on Inclined Surfaces. Environmental Progress \& Sustainable Energy, 37(1), 2017.

BALALI, Mohammad Hasan; NOURI, Narjes; RASHIDI, Mohammad, NASIRI, Adel and OTIENO, Wilkistar. A Multi-Predictor Model to Estimate Solar and Wind Energy Generations. International Journal of Energy Research, (July 2017):696-706, 2017.

BELLOS, Evangelos and TZIVANIDIS, Christos. Investigation of a Hybrid ORC Driven by Waste Heat and Solar Energy. Energy Conversion and Management, 156(July 2017):427-39, 2018.

BENITEZ-GUERRERO, Monica et al. Low-Cost Ca-Based Composites Synthesized by Biotemplate Method for Thermochemical Energy Storage of Concentrated Solar Power. Applied Energy, 210(August 2017):108-16, 2018.

CERINO ABDIN, Giulio and NOUSSAN Michel. Electricity Storage Compared to Net Metering in Residential PV Applications. Journal of Cleaner Production, 176:175-86, 2018.

CHEN, Chen; LOVEGROVE, Keith M.; SEPULVEDA Abdon and LAVINE, Adrienne S. Design and Optimization of an Ammonia Synthesis System for Ammonia-Based Solar Thermochemical Energy Storage. Solar Energy, 159 (November 2017):992-1002, 2018.

CHEN, Mengmeng; SHEN Yuesong; ZHU Shemin and LI Peiwen. Digital Phase Diagram and Thermophysical
Properties of KNO3-NaNO3-Ca(NO3)2ternary System for Solar Energy Storage. Vacuum, 145(3):225-33, 2017.

CHENG, Zhiqiang; ZHAO, Shengzhe; KANG, Lijuan; LI Mingtang and GAO, Zhiling. A Novel Preparation of Hollow TiO2nanotubes and Pine-Cone Shaped CdS Nanoparticles Coated for Enhanced Ultraviolet and Visible Light Photocatalytic Activity. Materials Letters, 214:80 83, 2018.

CHIRINO, Hermes; XU, Bem; XU, Xinhai and GUO, Penghua. Generalized Diagrams of Energy Storage Efficiency for Latent Heat Thermal Storage System in Concentrated Solar Power Plant. Applied Thermal Engineering, 129:1595-1603, 2018.

CIAMPI, Giovanni, ROSATO, Antonio and SIBILIO, Sergio. Thermo-Economic Sensitivity Analysis by Dynamic Simulations of a Small Italian Solar District Heating System with a Seasonal Borehole Thermal Energy Storage. Energy, 143:757-71, 2018.

COCCIA, G. et al. Experimental Characterization of a Solar Cooker with Thermal Energy Storage Based on Solar Salt. Journal of Physics: Conference Series, 923(1):0-10, 2017.

EBRAHIMI, M.; ARAMESH, M. and KHANJARI, Y. Innovative ANP Model to Prioritization of PV/T Systems Based on Cost and Efficiency Approaches: With a Case Study for Asia. Renewable Energy, 117:434-46, 2018.

EISAVI, Beneta, KHALILARYA, Shahram and CHITSAZ, Ata. Thermodynamic Analysis of a Novel Combined Cooling, Heating and Power System Driven by Solar Energy. Applied Thermal Engineering, 129:1219-29, 2018.

ELDIN, S. A. Shara.; ABD-ELHADY, M. S. and KANDIL, H. A.. Feasibility of Solar Tracking Systems for PV Panels in Hot and Cold Regions. Renewable Energy, 85:228-33, 2016.

ELMUSTAPHA, Houda; HOPPE Thomas and BRESSERS, Hans. Consumer Renewable Energy Technology Adoption Decision-Making; Comparing Models on Perceived Attributes and Attitudinal Constructs in the Case of Solar Water Heaters in Lebanon. Journal of Cleaner Production, 172:347-57, 2018.

ERRAISSI, Nouredine; RAOUFI, Mustapha; AARICH, Noura; AKHSASSI, Mohamed and AMIN BENNOUNA. Implementation of a Low-Cost Data Acquisition System for 'PROPRE.MA' Project. Measurement: Journal of the International Measurement Confederation, 117(September 2017):21-40, 2018.

FERREIRA, Agmar et al. Economic Overview of the Use and Production of Photovoltaic Solar Energy in Brazil. Renewable and Sustainable Energy Reviews, 81(July 2017):181-91, 2018.

FERTAHI, Saïf ed Dîn et al. Design and Thermal Performance Optimization of a Forced Collective Solar Hot Water Production System in Morocco for Energy Saving in Residential Buildings. Solar Energy, 160(July 2017):260 74, 2018.

GONZALEZ, Alonso; GRÁGEDA, Mario, and Svetlana USHAK. Assessment of Pilot-Scale Water Purification Module with Electrodialysis Technology and Solar Energy. 
Applied Energy, 206(September):1643-52, 2017.

International Energy Agency (IEA). World Energy Outlook 2017. International Energy Agency: Paris, France https://www.iea.org/weo2017/.

Retrieved (https://www.iea.org/weo2017/).

ISLAM, Shahid; DINCER, Ibrahim and YILBAS, Bekir Sami. Development, Analysis and Assessment of Solar Energy-Based Multigeneration System with Thermoelectric Generator. Energy Conversion and Management, 156(September 2017):746-56, 2018.

KYLILI, Angeliki, FOKAIDES, Paris A.; IOANNIDES, Andreas and KALOGIROU, Soteris. Environmental Assessment of Solar Thermal Systems for the Industrial Sector. Journal of Cleaner Production, 176:99-109, 2018.

MA, Zhiwei; BAO, Huashan and ROSKILLY, Anthony Paul. Feasibility Study of Seasonal Solar Thermal Energy Storage in Domestic Dwellings in the UK. Solar Energy, 162(July 2017):489-99, 2018.

WANG, Xingdong; GUAN, Zhengfei and WU, Feng. Solar Energy Adoption in Rural China: A Sequential Decision Approach. Journal of Cleaner Production, 168:1312-18, 2017.

\section{COPYRIGHT}

Copyright: the authors are solely responsible for the material included in the paper.

Submetido em: $12 / 08 / 2018$

Aprovado em: 13/12/2018 


\author{
Revista SODEBRAS - Volume 14 \\ $\mathrm{N}^{\circ} 157$ - JANEIRO/ 2019
}

\title{
DESENVOLVIMENTO DE UM PROGRAMA PARA ESTIMATIVA DE PARÂMETROS LONGITUDINAIS E TRANSVERSAIS DE LINHAS DE TRANSMISSÃO AÉREA EM CORRENTE ALTERNADA
}

\section{DEVELOPMENT OF A PROGRAM FOR ESTIMATION OF LONGITUDINAL AND TRANSVERSAL PARAMETERS OF ALTERNATE CURRENT OVERHEAD TRANSMISSION LINES}

\author{
KAIO CESAR MACIEL NASCIMENTO ${ }^{1}$; STEFANI CAROLLINE LEAL DE FREITAS ${ }^{1}$; PRISCILA DA \\ SILVA OLIVEIRA ${ }^{1}$; CLEINER DA SILVA ASSIS $^{2}$; ALCY MONTEIRO JUNIOR ${ }^{1}$; ADELICIO MAXMIANO \\ SOBRINHO $^{1}$; SÉRGIO MANUEL RIVERA SANHUEZA $^{1}$; MARILENE ANDREIA MANTOVANI ${ }^{1}$ \\ 1 - UNIVERSIDADE FEDERAL DO TOCANTINS; 2 - ELETROBRAS ELETRONORTE - DIV. DE \\ COORD. TÉCNICA - OTLTC \\ kcesar1905@gmail.com; stefaniclf@uft.edu.br;pri.s.o@uft.edu.br; cleiner.assis@eletronorte.gov.br, \\ alcy.monteiro@uft.edu.br,adelmax@uft.edu.br,sergiorivera@uft.edu.br; marilene.mantovani@uft.edu.br
}

\begin{abstract}
Resumo - Este trabalho apresenta o desenvolvimento de um aplicativo computacional que realiza os cálculos para estimativa de parâmetros de linhas de transmissão aérea em corrente alternada a circuito simples ou a circuito duplo. Tais parâmetros, notadamente, indutância, reatância indutiva, capacitância, susceptância capacitiva e reatância capacitiva, têm impacto direto no projeto de uma linha de transmissão, uma vez que são utilizados para dimensionar elementos de proteção do circuito $e$ prever, consequentemente, o rendimento da linha. $O$ desenvolvimento do aplicativo foi realizado com um programa gratuito, com base na teoria de modelagem de um circuito $\pi$ nominal, utilizado para estimativa de parâmetros longitudinais $e$ transversais de linhas de transmissão. Para validação, os resultados obtidos pelo programa foram comparados com os dados uma linha de transmissão real.
\end{abstract}

Palavras-chave: Capacitância. Indutância. Linha de Transmissão.

Abstract - This work presents the development of a computational application that performs calculations for the estimation of alternating current overhead transmission lines parameters, to single circuit or double circuit. Such parameters, in particular, inductance, inductive reactance, capacitance, capacitive susceptance and capacitive reactance, have a direct impact on a transmission line project, since they are used to dimension protection elements of the circuit and, consequently, to predict line efficiency. The application development was carried out with a free program, based on the modeling theory of a nominal $\pi$ circuit, used to estimate longitudinal and transverse parameters of transmission lines. For validation, the results obtained by the program were compared with the data of a real transmission line.

Keywords: Capacitance. Inductance. Transmission Line.

\section{INTRODUÇÃO}

Os estudos da transmissão de energia em corrente alternada (CA) demandam especial atenção devido à alta complexidade das análises e da operação dos sistemas interligados.

Em nível nacional, a complexidade mencionada se dá, especialmente, pelas características de nossa matriz energética, onde grande parte das mais volumosas bacias hidrográficas encontra-se distante dos grandes centros de consumo (ELETROBRAS, 2007). Essa distância resulta no extenso comprimento das linhas de transmissão (LTs), e aponta a necessidade de uma série de subestações, ao longo do percurso das linhas, para o seccionamento e a interligação de circuitos, como também para a compensação das perdas.

Nos sistemas de transmissão em CA, além das perdas por calor, há também perdas adicionais decorrentes da variação da tensão nos condutores (FUCHS, 1977). Essas perdas estão relacionadas a dois parâmetros que estão uniformemente distribuídos ao longo da linha de transmissão. São eles: os parâmetros longitudinais, ou série, e os parâmetros transversais, ou shunt.

A resistência e indutância são parâmetros série, que estão associados, respectivamente, à dissipação de potência ativa (lei de Joule) e aos campos magnéticos (FERRONI, 2014) devido à passagem de corrente elétrica.

Já os parâmetros shunt estão associados à condutância, que representa as correntes de fuga, e a capacitância, que se deve aos campos elétricos formados devido à diferença de potencial entre os condutores e também em relação ao solo. Vale destacar, que apenas as perdas por efeito joule são comuns aos sistemas de transmissão de energia em CA e em CC.

A determinação da resistência do condutor de uma LT está diretamente relacionada à capacidade de condução de corrente do cabo, considerando operações rotineiras e as possíveis interligações de circuitos para transferência de carga.

Já os valores dos parâmetros de indutância (L) e capacitância (C) estão atrelados às características construtivas e operacionais da linha, como: altura dos condutores em relação ao solo; espaçamento dos condutores de uma mesma fase; tipo e diâmetro dos condutores; distância entre o centro das fases; comprimento das linhas e frequência de operação do sistema.

Em projetos de LTs é importante ter precisão nas estimativas dos preconizados parâmetros, pois, além de 
serem valores determinantes para os cálculos das perdas, eles estão diretamente ligados à potência da linha, aos valores suportáveis de correntes de curto-circuito, à capacidade de condução de corrente em condições nominais e à queda de tensão na linha de transmissão.

Consequentemente, os parâmetros supracitados possuem influência direta na determinação de elementos de proteção, medição e nos compensadores de reativos da linha. Dado isso, os cálculos para uma modelagem adequada dos parâmetros da linha são fundamentais não apenas para assegurar a confiabilidade da operação nas condições previstas, mas também para garantir a suportabilidade da linha a fenômenos de transitórios eletromagnéticos.

Neste contexto, este trabalho apresenta o desenvolvimento de um aplicativo computacional que calcula os parâmetros de LTs aérea de circuito simples ou duplo.

O programa foi desenvolvido na linguagem Python e a plataforma de desenvolvimento e o compilador utilizado são softwares livres. Sendo assim, o código é de fácil acesso, podendo ser aberto tanto em sistemas operacionais livres e gratuitos como também em sistemas privados. Essa linguagem é bem simples, sendo, portanto, de fácil compreensão.

Os resultados analíticos obtidos, via aplicativo computacional desenvolvido, são comparados validados a partir de dados reais de uma LT de $500 \mathrm{kV}$ localizada no Estado do Tocantins. Trata-se de uma linha de transmissão importante, conectada ao Sistema Interligado Nacional (SIN).

\section{DIRETRIZES TEÓRICAS}

Uma vez que os dados do fabricante dos condutores utilizados na LT já fornecem os valores de resistência por unidade de comprimento, já prevendo o efeito pelicular e o acréscimo da resistência devido ao encordoamento, o desenvolvimento do programa direcionou cuidados aos cálculos de indutância, capacitância e suas respectivas reatâncias.

O modelo de linha de transmissão $\pi$ para parâmetros distribuídos (FUCHS, 1977), ilustrado na figura 1, foi adotado como base para a estimativa dos parâmetros longitudinais, resistência $(R)$ e indutância $(L)$, e transversais, capacitância $(C)$, como ilustra a figura 1 .

Figura 1 - Linha de transmissão $\pi$ com parâmetros distribuídos

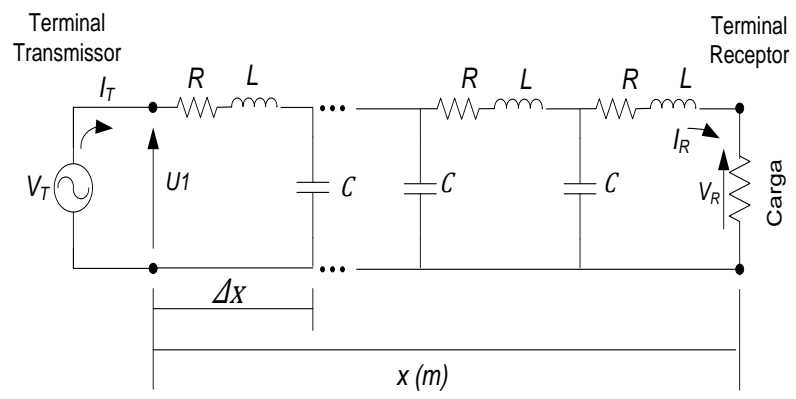

Fonte: Elaboração dos autores.

Observa-se pela figura 1 que, entre os terminais transmissor e receptor, o circuito $\pi$ se repete a cada unidade de comprimento $(x)$ da LT.

\footnotetext{
1 A presença dos cabos para-raios nas torres não apresenta significativa alteração nos valores finais dos parâmetros, e por isso seus efeitos podem ser desprezados.
}

Para referencial teórico das formulações e equações mostradas na seção seguinte deste trabalho, foi tomada como base a reconhecida e renomada referência de FUCHS, 1977. Essas equações são a base dos cálculos de parâmetros por fase de linhas de transmissão trifásicas em CA, abrangendo os vários modelos de torres de transmissão, com circuitos simples ou duplo, estaiadas ou autoportantes, com diferentes geometrias entre fases. Em (TAVARES, 2015) é possível ver o exemplo de seis modelos de estruturas de linhas comumente utilizadas.

É importante destacar que para os casos de linhas trifásicas com espaçamento assimétrico entre as fases, considera-se a transposição de fases a cada $1 / 3$ do comprimento total da linha. A finalidade dessa transposição é restaurar o equilíbrio das fases, do ponto de vista dos terminais receptores da linha.

\section{A. Indutância}

Para viabilizar a compreensão da análise das variáveis que interferem na indutância ${ }^{1}$ por fase de uma linha de transmissão, considera-se o sistema trifásico ilustrado na figura 2, salientando que, embora a geometria dessa linha seja triangular, as análises servem de igual modo para geometrias verticais e horizontais, seguindo o mesmo raciocínio.

Figura 2 - Linha de transmissão trifásica, geometria triangular

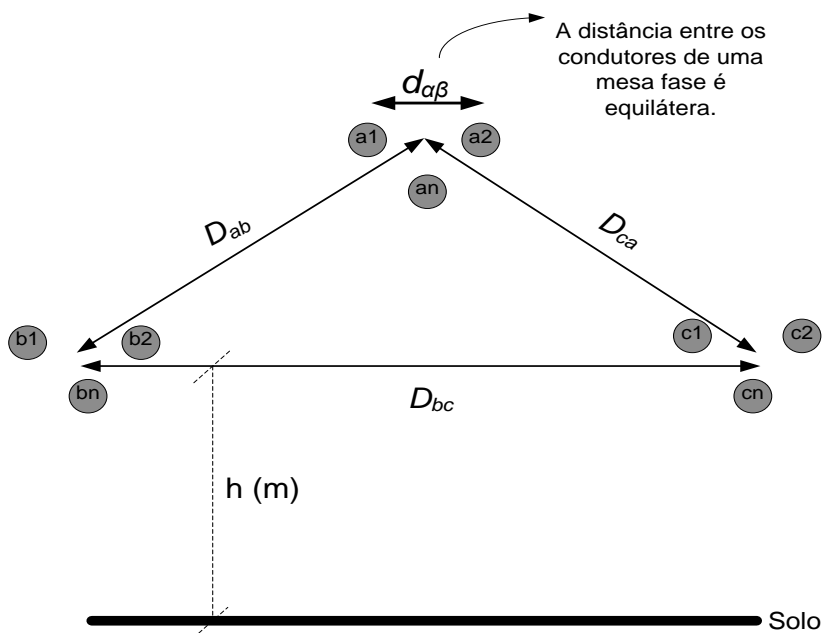

Fonte: Elaboração dos autores.

A indutância média por fase da linha é dada por:

$$
L=\frac{\mu}{2 \pi} \cdot \ln \frac{D m g}{R m g}(\mathrm{H} / \mathrm{m})
$$

Sendo:

$L$ a indutância média por fase e por unidade de comprimento. $\mu \quad$ a permeabilidade do meio (normalmente é usada apenas a permeabilidade do vácuo $\mu_{0}=4 \pi \cdot 10^{-7}\left(\frac{H}{m}\right)$, pois a permeabilidade relativa do ar $\mu_{r} \approx 1$ ).

$D m g$ é a distância média geométrica entre as fases. $R m g$ é o raio médio geométrico das fases.

A distância média geométrica é calculada pela a equação (2), que leva em consideração a distância entre os centros das fases. 


$$
D m g=\sqrt[3]{D_{a b} D_{\mathrm{bc}} D_{c a}}
$$

O cálculo do raio médio geométrico equivalente da fase, $R m g$, é dado pela equação (3), onde se considera que a fase é composta por 3 condutores.

$$
R m g=\sqrt[n^{2}]{\left(r_{a 1}^{\prime} \cdot d_{a 1 a 2} \cdot d_{a 1 a n}\right) \ldots\left(r_{a n}^{\prime} d_{a n a 1} \cdot d_{a n a 2}\right)}
$$

Sendo:

$n$ é o número de condutores por fase $r_{a n}^{\prime}$ é o raio médio geométrico do condutor analisado ${ }^{2}$. $d_{\alpha \beta}$ é a distância em metros do condutor $\alpha$ ao condutor $\beta$ de uma mesma fase.

Destaca-se que nos sistemas de transmissão trifásicos, cada fase pode ter de 1 até 4 condutores afim de dividir a corrente de transmitida por cada fase e assim reduzindo a seção dos cabos correspondentes ${ }^{3}$. Sendo assim, para o caso de condutores, na análise do raio médio geométrico, haveriam $16\left(4^{2}\right)$ termos se multiplicando dentro da raiz.

\section{B. Capacitância}

A figura 3 ilustra uma linha trifásica triangular, com n condutores por fase, a fim de elucidar a composição da equação (4).

Além das distâncias entre o centro das fases e entre os condutores de uma mesma fase, neste caso leva-se em consideração o efeito do solo sobre a capacitância determinado pelo método das imagens (FERRONI, 2014), como pode ser analisado a seguir.

$$
C_{a N}=\frac{2 \pi \varepsilon}{\ln \left(\frac{D m g}{R g e} \cdot \frac{\sqrt[3]{H a \cdot H b \cdot H c}}{\sqrt[3]{H a b^{\prime} . H b c^{\prime} \cdot H c a^{\prime}}}\right)}(\mathrm{F} / \mathrm{m})
$$

Sendo:

$H \alpha \quad$ a altura média da fase $\alpha$

$H \alpha \beta$ a distância da fase $\alpha$ à fase imagem $\beta$

$D m g$ a distância média geométrica entre as fases.

$R g e$ o raio geométrico equivalente.

O Rge o é calculado conforme com raciocínio semelhante ao $R m g$, porém, se considera o raio efetivo, $r$, do condutor, sendo que, para linhas com:

- 1 condutor por fase: $R g e=r$

- 2 condutores por fase: $R g e=\sqrt{r \cdot d}$

- 3 condutores por fase: $R g e=\sqrt[3]{r \cdot d^{2}}$

- 4 condutores por fase: $R g e=1,09 \sqrt[4]{r \cdot d^{3}}$
Figura 3 - Linha de transmissão considerando o efeito do solo sobre a capacitância

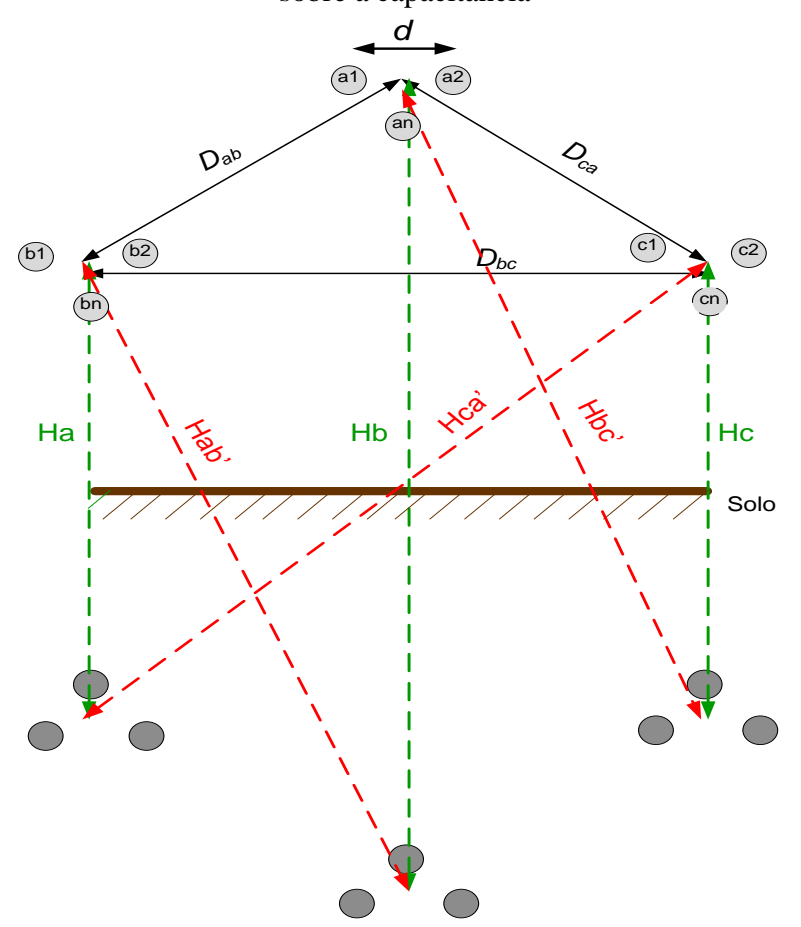

Fonte: Elaboração dos autores.

\section{Reatâncias}

Por fim, a partir desses dados pode-se determinar as reatâncias indutiva $\left(X_{L}\right)$ e capacitiva $\left(X_{C}\right)$, e também a susceptância capacitiva $\left(B_{C}\right)$ totais por fase da LT trifásica. Estes valores são obtidos por meio das equações (6) a (8), respectivamente.

$$
\begin{aligned}
X_{L} & =\omega \cdot L \cdot x \quad(\Omega) \\
X_{C} & =\frac{1}{\omega \cdot C} \cdot \frac{1}{x}(\Omega) \\
B_{C} & =\omega \cdot C \cdot x \quad(S)
\end{aligned}
$$

Sendo:

$\omega$ a frequência angular em rad/s, dada por $2 * \pi *$ frequência $x$ é o comprimento da LT.

\section{DESENVOLVIMENTO DO APLICATIVO COMPUTACIONAL}

O aplicativo em questão neste trabalho foi desenvolvido utilizando a linguagem Python 3.4.3, sendo o IDLE o ambiente de desenvolvimento integrado. Trata-se de um software de acesso livre e de fácil utilização, sendo leve, consome pouca memória do computador, podendo ser utilizado em computadores mais simples sem ocorrer erro ou travamentos. O IDLE foi utilizado na parte relacionada aos algoritmos que executam os cálculos dos parâmetros da LT. A figura 4 ilustra a tela de desenvolvimento.

Com relação ao desenvolvimento da interface gráfica, optou-se por utilizar o software Qt Creator, devido à sua simplicidade, comparado a outros softwares com fins semelhantes, bem como pelo fato de ser gratuito.

\footnotetext{
${ }^{2}$ Devido ao efeito pelicular, raio médio geométrico considerado para cálculo da indutância do condutor $\alpha$ em uma linha operando a $60 \mathrm{~Hz}$ é: $r_{\alpha}^{\prime}=$ raio do condutor $\alpha .0,7788$
}

${ }^{3} \mathrm{O}$ número de condutores por fase está relacionado com a classe de tensão e carregamento da linha. 
Os dados de entrada do programa são: número de fases, distâncias entre as fases, altura das fases, quantidade de cabos por fase, e o espaçamento entre eles, a flecha e o comprimento da LT e a frequência de operação.

Os testes do programa foram realizados em duas etapas. A primeira delas utilizou, como base, exercícios propostos na literatura. Deste modo os resultados fornecidos pela literatura foram comparados aos resultados obtidos por meio do aplicativo desenvolvido. A segunda etapa de teste se deu por meio da comparação entre os resultados fornecidos pelo aplicativo e os dados de LT real, que será descrita na seção seguinte.

Figura 4 - Ambiente de desenvolvimento IDLE

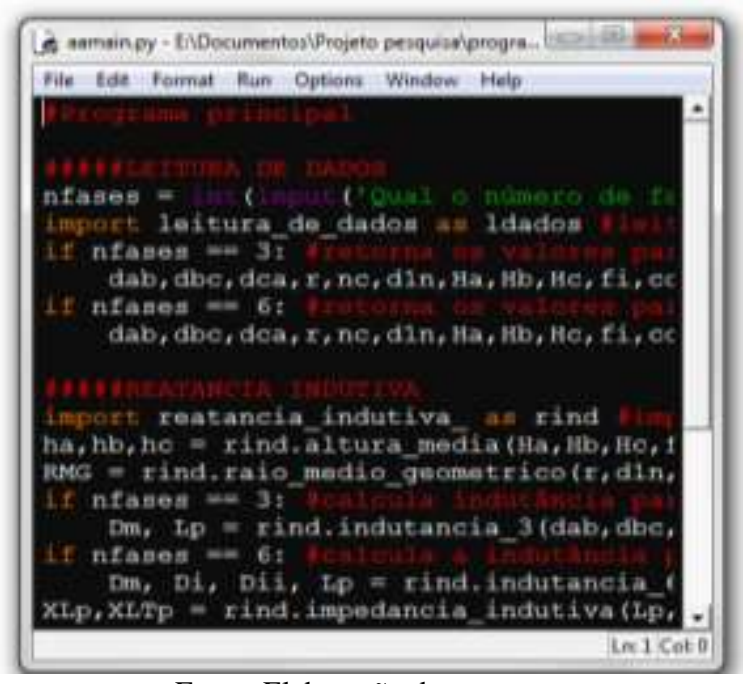

Fonte: Elaboração dos autores.

\section{CARACTERÍSTICAS DA LINHA DE TRANSMISSÃO ANALISADA}

Os dados da linha de transmissão utilizados para validar a pesquisa desenvolvida está situada no centro do Estado do Tocantins. É uma das linhas que faz a conexão norte-sul do SIN (Sistema Interligado Nacional).

Esta LT possui torres do tipo raquete compacta, autoportante, com apenas um circuito por torre, 4 condutores por fase, com diâmetros de 29,59 cm, e ângulo entre fases definidos conforme mostra a figura 5 .

As alturas das fases A e C são de 41,307 m e a altura da fase B é de 45,156 m. Possui uma extensão de 174,03 km, tensão nominal de $500 \mathrm{kV}$ e corrente de projeto de $3000 \mathrm{~A}$. Os valores dos parâmetros elétricos são mostrados na tabela 1 .

Tabela 1- Parâmetros elétricos da LT real

\begin{tabular}{c|c}
\hline Parâmetros & Valores \\
\hline Indutância média por fase $(\mathrm{H} / \mathrm{km})$ & 0,0007082281 \\
\hline Reatância indutiva $(\Omega / \mathrm{km})$ & 0,267002 \\
\hline Capacitância média por fase $(\mathrm{nF} / \mathrm{km})$ & 16,3779045 \\
\hline Susceptância capacitiva $(\mu \mathrm{S} / \mathrm{km})$ & 6,17447 \\
\hline Reatância capacidade $(\mathrm{M} \Omega . \mathrm{km})$ & 0,1619572206 \\
\hline \multicolumn{2}{c}{ Fonte: ELETROBRAS ELETRONORTE, 2017.}
\end{tabular}

A figura 6 mostra uma imagem real de uma estrutura autoportante tipo raquete.
Figura 5 - Desenho referencial da estrutura metálica da torre de suporte da LT

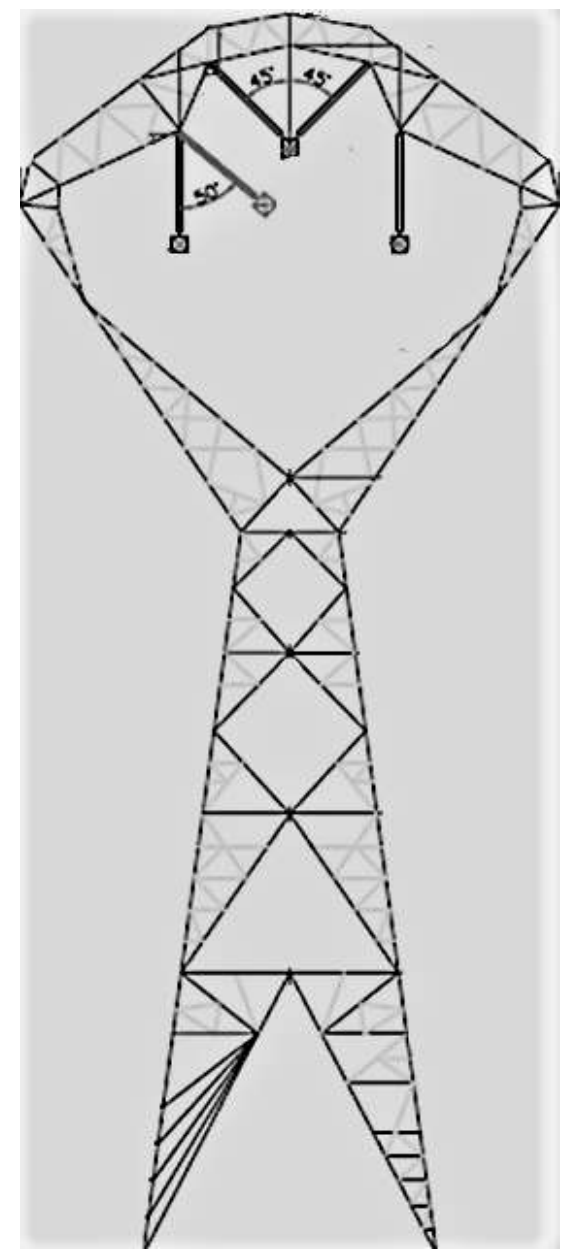

Fonte: Adaptado de ELETROBRAS ELETRONORTE, 2017.

Figura 6 - Torre com estrutura autoportante do tipo raquete

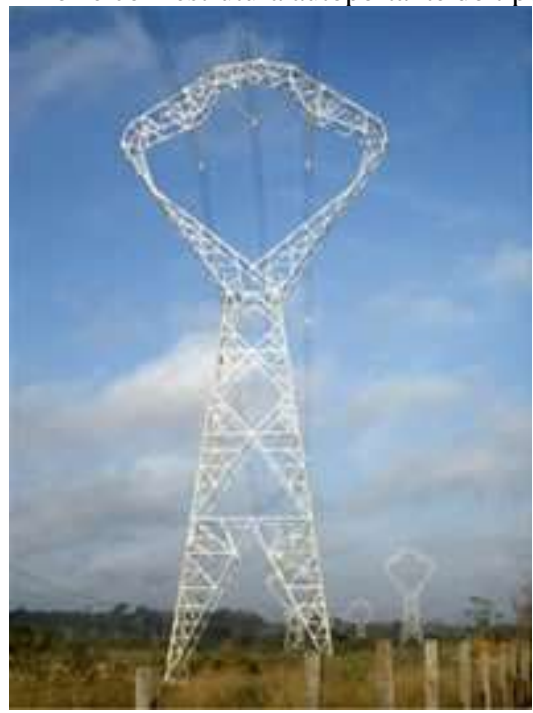

Fonte: Portal Metálica Construção Civil, 2018.

\section{RESULTADOS E VALIDAÇÃO}

Após o levantamento de dados sobre a LT citada, deuse início à validação do algoritmo montado. Inicialmente foram inseridos os valores de entrada (dimensões e espaçamentos entre condutores) de acordo com as informações coletadas da LT. Os resultados obtidos estão na tabela 2 . 
Tabela 2 - Resultados obtidos pelo programa

\begin{tabular}{c|c}
\hline Parâmetros & Valores \\
\hline Indutância média por fase $(\mathrm{H} / \mathrm{km})$ & 0.0006933836 \\
\hline Reatância indutiva $(\Omega / \mathrm{km})$ & 0.2613994889 \\
\hline Capacitância média por fase $(\mathrm{nF} / \mathrm{km})$ & 16.3335370 \\
\hline Susceptância capacitiva $(\mu \mathrm{S} / \mathrm{km})$ & 6.157598402 \\
\hline Reatância capacidade $(\mathrm{M} \Omega . \mathrm{km})$ & 0.1626009775 \\
\hline
\end{tabular}

Fonte: Elaboração dos autores.

Para validação dos resultados, uma importante análise feita foi destinada a levantar os erros percentuais, calculado com base comparativa entre o valor real dos parâmetros da linha analisada e dos valores obtidos por meio do programa desenvolvido neste trabalho.

Os erros percentuais calculados são mostrados na tabela 3. Os parâmetros apresentados referem-se apenas à indutância e à capacitância , uma vez que as respectivas reatâncias são oriundas desses valores e apresentariam erros percentuais idênticos.

Tabela 3 - Erros percentuais

\begin{tabular}{c|c} 
Parâmetro & Erro \\
\hline Indutância média por fase & $2,1 \%$ \\
\hline Capacitância média por fase & $0,27 \%$ \\
\hline \multicolumn{2}{c}{ Fonte: Elaboração dos autores. }
\end{tabular}

Pela análise dos erros percentuais percebe-se que os mesmos são bastante baixos, o que valida o programa e sinaliza a confiabilidade para continuidade desta pesquisa, no sentido de realizar estudos mais detalhados relacionados à outros modelos de torres, à variação de corrente, tensão e de perdas ao longo de linhas de transmissão aéreas.

\section{CONCLUSÃO}

Este trabalho apresentado destinou-se a elaboração de um programa para cálculo de parâmetros de linhas de transmissão aérea em corrente alternada.

Foram apresentadas as diretrizes teóricas que nortearam os cálculos realizados pelo programa, bem como o software utilizado em sua composição. Destaca-se o fato de que o software utilizado é livre.

Por meio da comparação dos resultados calculados pelo programa e dos valores dos parâmetros de uma linha de transmissão real, pôde-se avaliar e validar o programa, uma vez que os resultados calculados pelo programa tiveram erros percentuais pequenos. Sendo que o erro para a indutância média por fase foi de $2,1(\%)$ e para a capacitância média por fase de foi de $0,27(\%)$.

Sendo assim, o programa desenvolvido se estabelece como confiável e torna-se uma ferramenta de apoio tanto para estudantes quanto para profissionais que desejam pesquisar na área de projetos de LTs.

Neste sentido, como proposta de continuidade desta pesquisa, vislumbram-se estudos detalhados sobre a variação de tensão e corrente ao longo de linhas, bem como do seu rendimento associado a diferentes possibilidades de estruturas de LTs.

\section{AGRADECIMENTOS}

Os autores agradecem à Eletrobrás Eletronorte - Regional Tocantins, e ao Programa de Educação Tutorial (PET) do curso de engenharia elétrica da Universidade Federal do Tocantins.

\section{REFERÊNCIAS}

ELETROBRAS. Manual de Inventário Hidroelétricos de Bacias Hidrográficas. 3. ed, 2007.

ELETROBRAS ELETRONORTE. Uso de dados autorizados. (DEPT. DE GEST. INOVAÇÃO E EFIC. ENERGÉTICA - OEMI). 22 de maio de 2017. Não publicado.

FERRONI, Eduardo H., CÉSAR, Filipe., VIEIRA, Hugo. R., LUZ, Marcos C. Análise das metodologias para cálculo de campo magnético originado por linhas de transmissão. Revista SODEBRAS, v. 9. N. 107, 2014.

FUCHS, Rubens Dario. Transmissão de energia elétrica: linhas aéreas; teoria das linhas em regime permanente. Rio de Janeiro: LTC, 1977. 2v.

Portal Metálica Construção Civil. Figura 6. Disponível em: <http://wwwo.metalica.com.br/images/stories/Id1577/torremetalica-autoportante-8.jpg.> Acesso em 22 de fevereiro de 2018.

TAVARES, G. M., SANTIAGO, N. H.C., FILHO, J. A., RIGUEIRA, A. S., IZICKY, M. J, PEDRO, B. S., ALVARENGA, L. F., FORTES, M. Z. Ferramenta Computacional para avaliação ótima da coordenação ótima de isolamento de linhas de transmissão. Revista SODEBRAS, v. 10, n. 114, 2015.

\section{COPYRIGHT}

Direitos autorais: Os autores são os únicos responsáveis pelo material incluído no artigo.

Submetido em: 23/10/2018 Aprovado em: 19/11/2018 


\author{
Revista SODEBRAS - Volume 14 \\ $\mathrm{N}^{\circ} 157$ - JANEIRO/ 2019
}

\title{
MEDIDAS PARA REDUZIR O CONSUMO DE ENERGIA NO SETOR RESIDENCIAL - UMA REVISÃO
}

\author{
MEASURES FOR REDUCING ENERGY CONSUMPTION IN THE \\ RESIDENTIAL SECTOR - A REVIEW
}

\author{
THAMYRES MACHADO DAVID ${ }^{1}$; TEÓFILO MIGUEL DE SOUZA²; PALOMA MARIA SILVA ROCHA \\ RIZOL $^{2}$; MARCELA APARECIDA GUERREIRO MACHADO ${ }^{1}$, LUCIANO LIZARDO DE SOUZA GUIMARÃES ${ }^{3}$ \\ 1 - UNIVERSIDADE ESTADUAL PAULISTA (UNESP), DEPARTAMENTO DE ENGENHARIA DE \\ PRODUÇÃO; 2 - UNIVERSIDADE ESTADUAL PAULISTA (UNESP), DEPARTAMENTO DE ENGENHARIA \\ ELETRICA; 3 - UNIVERSIDADE ESTADUAL PAULISTA (UNESP), DEPARTAMENTO DE ENERGIA \\ md.thamyres@gmail.com, teofilo_miguel@yahoo.com.br,paloma.rizol@unesp.br, marcela@feg.unesp.br, \\ luciano_lizardo@hotmail.com
}

\begin{abstract}
Resumo - Devido às limitações atuais das fontes de energia para atender a demanda estarem cada vez mais desafiadoras, medidas $e$ atitudes para reduzir o consumo de energia tornaram-se de grande relevância. Apesar de significativas oportunidades de melhoria da eficiência energética estarem no setor residencial, alguns autores questionam a gestão governamental para o atual cenário energético. $O$ objetivo deste artigo é revisar os resultados mais recentes dos artigos publicados sobre medidas de economia de energia no setor residencial e destacar quais medidas estão sendo mais abordadas $e$ quais têm maior impacto na redução de energia.
\end{abstract}

Palavras-chave: Eficiência Energética. Medidas de Eficiência. Consumo de Energia. Residencial. Economia de Energia.

\begin{abstract}
Growing numbers of reports from international energy research agencies and institutions are alarming. Due the current limitations of energy sources to meet demand are increasingly challenging, measures and attitudes to reduce energy consumption have become of major relevance. Despite to significant energy efficiency improvement opportunities are in the residential sector, some authors question government management for the current energy scenario. The aim of this paper is to review the findings more recent of published papers on energy-saving measures in the residential sector and to highlight which measures are being addressed most and which have a greater impact of energy reduction.
\end{abstract}

Keywords: Energy Efficiency. Efficiency Measures. Energy Consumption. Residential. Energy Saving.

\section{INTRODUÇAO}

$\mathrm{O}$ número crescente de relatórios de agências internacionais e instituições de pesquisa de energia são alarmantes. Devido às limitações atuais das fontes de energia para atender à demanda estarem cada vez mais desafiadoras, medidas e atitudes para reduzir o consumo de energia tornaram-se de grande relevância. Em 2016, de acordo com a Agência Internacional de Energia (2018), a produção bruta de eletricidade foi de 2,9\% superior à de 2015. Ano após ano, a produção global de eletricidade tem crescido continuamente desde 1974.

Apesar de significativas oportunidades de melhoria de eficiência energética estarem no setor residencial (WADA et al, 2012), alguns autores questionam a gestão do governo para o cenário atual de energia, como Antonakakis et al (2017), que abordam a eficácia das políticas governamentais recentes em vários países para promover o consumo de energia renovável como um meio para o crescimento sustentável. Ou a publicação do Fossati et al (2016) que trata da aplicação do regulamento para a rotulagem da eficiência energética dos edifícios residenciais brasileiros.

A preocupação com o consumo de energia e eficiência energética no setor residencial não é um problema atual. No início dos anos 2000, artigos relacionados com o tema já haviam sido publicados (EDINGER; KAUL, 2000; HENS; VERBEECK; VERDONCK, 2001; MIRASGEDIS et al, 2002; BIRD; WÜSTENHAGEN; AABAKKEN, 2003; TANATVANIT; LIMMEECHOKCHAI; CHUNGPAIBULPATANA, 2003; PAPADOPOULOS; OXIZIDIS; KYRIAKIS, 2003; AYDINALP; UGURSAL; FUNG, 2004; HEPBASLI E OZGENER, 2004). Grande parte do crescimento no consumo de energia elétrica nos países desenvolvidos desde 1974 ocorreram nos setores residenciais, comerciais e de serviços públicos. Embora a quantidade de eletricidade consumida na indústria tenha aumentado entre 1974 e 2016, a participação das residências no consumo total de eletricidade foi maior (IEA, 2018). Assim, alguns fatores (ZHOU et al, 2016; GUO et $a l, 2016$; SUBRAMANYAM et al, 2017; JIA et al, 2018) provaram reduzir o consumo de energia no setor residencial. Com base em estudos recentes, os assuntos nas quais os artigos desta revisão foram subdivididos são baseados em: incentivos financeiros, energia renovável, isolamento térmico, políticas públicas e cogeração ou produção combinada de calor e eletricidade (CHP).

Portanto, o objetivo deste trabalho é revisar as descobertas mais recentes dos artigos publicados sobre as medidas de economia de energia no setor residencial e destacar quais medidas estão sendo mais abordadas e quais têm um maior impacto da redução de energia. O setor industrial não está incluído na revisão, uma vez que os dois setores são muito diferentes em vários aspectos. $\mathrm{O}$ documento não tem a pretensão de apresentar uma descrição exaustiva de todas as medidas possíveis, e sim se concentrar em medidas de eficiência energética específicas para o setor residencial. 
Este artigo está organizado em cinco seções. Na primeira seção é identificado o problema de pesquisa, o objetivo e o significado. A segunda seção descreve a metodologia da revisão da literatura. A terceira seção descreve as publicações relacionadas as medidas encontradas. A quarta seção apresenta a discussão dos resultados. E, finalmente, a quinta seção apresenta as conclusões do estudo.

\section{METODO}

O estudo nesta revisão pode ser dividido em duas partes: (1) Pesquisa Quantitativa e (2) pesquisa qualitativa. A primeira parte foi uma busca com uma ampla gama de cadeias de pesquisa baseado em palavras-chave relacionadas ao tema. Algumas das referências encontradas deram inspiração para novas sequências de pesquisa. $\mathrm{O}$ ponto de partida foi artigos que abordaram consumo de energia, em particular os documentos que tratavam do setor residencial. A Figura 1 mostra uma representação gráfica do processo de pesquisa, as buscas de pesquisa utilizadas e os seus resultados. Esses documentos apresentaram uma série de medidas de redução de consumo de energia e deram alguma compreensão do campo que foi útil para a revisão.

Nas buscas 1 e 2, as palavras foram pesquisadas nos títulos, palavras-chave e resumos na base de dados Scopus. Uma vez que um grande número de publicações relevantes foi obtido nestas pesquisas (1 e 2), as buscas 3, 4, 5 e 6 foram limitadas a pesquisar apenas nos títulos dos artigos. As buscas foram primeiramente limitadas aos últimos cinco anos (2015 2019). Para a identificação de que os artigos são exclusivamente relacionados com as medidas para reduzir o consumo de energia limitada a residências, os títulos e resumos de todos os artigos foram analisados. Aqueles que não estavam no escopo desta pesquisa foram eliminados depois de verificar o texto do próprio artigo. As palavras-chave utilizadas para a coleta de dados incluem "consumo de energia", "residencial", "residência", "demanda de energia", "eficiência energética" e "utilização de energia". Foram utilizadas seis combinações destas palavras-chave com operadores booleanos para combinar os termos de pesquisa. Finalmente, os artigos foram lidos completamente, e os que continham informações relevantes foram incluídos na revisão.

Figura 1 - Pesquisa quantitativa
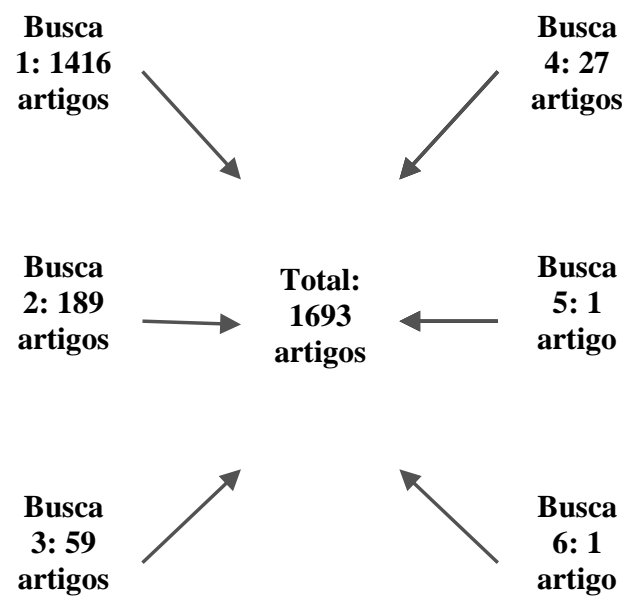

• Busca 1: "consumo de energia" e "residencial". [Título, resumo e palavras-chave]

• Busca 2: "consumo de energia" e "residência". [Título, resumo e palavras-chave]
- Busca 3: "demanda de energia" e "residencial". [Título]

- Busca 4: "eficiência energética" e "consumo de energia". [Título]

- Busca 5: "eficiência energética" e "utilização de energia".[Título]

• Busca 6: "demanda de energia" e "residência". [Título]

Fonte: Autores, 2018.

Em alguns casos, foram identificadas medidas relevantes para reduzir o consumo de energia através do processo de pesquisa acima. As publicações recolhidas na lista de pesquisa bibliográfica foram organizadas com base em seu assunto principal nas seguintes categorias: cogeração ou produção combinada de calor e eletricidade (CHP), políticas públicas, isolamento térmico, energia renovável e incentivos financeiros. No total, 60 referências científicas foram incluídas na revisão. As publicações foram divididas em tópicos mencionados anteriormente para destacar tanto o estado atual e os aspectos que precisam ser melhorados em diferentes níveis de desempenho energético.

\section{RESULTADOS}

\section{1 - Consumo energético}

O número crescente dos relatórios de agências internacionais e instituições de pesquisa de energia são alarmantes. Devido às limitações atuais de fontes de energia para atender à demanda estarem cada vez mais desafiadoras, medidas e atitudes para reduzir o consumo de energia se tornaram de grande relevância. Em 2016, de acordo com a Agência Internacional de Energia (2018), a produção bruta de eletricidade foi de 2,9\% superior à de 2015. Ano após ano, a produção global de eletricidade tem crescido continuamente desde 1974. Já o consumo, alcançou 20,863 TWh, 3,2\% acima do valor de 2015. A taxa média de crescimento no consumo final de eletricidade no mundo entre 1974 e 2016 foi de 3,3\%. No que diz respeito ao tipo de geração, a partir de combustíveis representavam $67,3 \%$ da produção total de eletricidade bruta (dos quais: 65,1\% a partir de combustíveis fósseis; 2,3\% de biocombustíveis e resíduos), centrais hidrelétricas (incluindo armazenamento e bombeado) proporcionaram 16,6\%; plantas nucleares $10,4 \%$; geotérmica, solar, eólica, marés e outras fontes de $5,6 \%$; e biocombustíveis e resíduos contemplavam o restante de 2,3\%. Note-se que a quota de energias renováveis ainda é muito menor em comparação com outras fontes, como as a partir de combustíveis fósseis, por exemplo, que além de impactar o meio ambiente, é apoiado por recursos escassos, contrariando o desenvolvimento sustentável.

Apesar de significativas oportunidades de melhoria de eficiência estar no setor residencial (WADA et al, 2012), alguns autores questionam a gestão do governo para o cenário atual do setor energético, como Antonakakis et al (2017), que abordam a eficácia das políticas governamentais recentes em vários países para promover o consumo de energia renovável como um meio para o crescimento sustentável. Ou a publicação do Fossati et al (2016) que trata da aplicação do regulamento de rotulagem de eficiência energética de edifícios residenciais brasileiros. Apesar de ser recente e voluntária, a implementação do regulamento residencial representa um marco regulatório. Ainda é necessária uma revisão para conseguir um processo mais flexível e economicamente viável que permita ao programa estabelecer uma natureza compulsória e ser mais amplamente aceito. 
Outro fator que impacta esse cenário é o comércio de energia elétrica. O comércio de eletricidade entre países vizinhos tornou-se muito mais comum. Ao relatar os fluxos de energia elétrica, os países usam o comércio de eletricidade como um "equilíbrio", levando a uma considerável variação nos dados de importação e exportação. Além disso, as perdas de transmissão e distribuição de linha entre os importadores e exportadores geralmente são grandes (IEA, 2018), mostrando ser uma estratégia ineficiente do ponto de vista socioeconômico.

Uma limitação que também corrobora com este cenário energético é o preço da energia, os preços da energia normalmente não introduzem as externalidades ambientais derivadas do uso de energia. Se o preço da energia não corresponder ao custo marginal real, a adoção de medidas de eficiência energética não é incentivada. É necessário levar os preços ao nível certo, incluindo os custos sociais. Outro estudo (REDDY, 1995) comenta que as elasticidades de preços que são difíceis de estimar, por causa do subsídio oculto nos preços da energia, não apresentam um quadro correto. $\mathrm{O}$ preço da eletricidade, particularmente para o setor residencial, está bem abaixo do custo marginal. Portanto, deve haver não apenas incentivos para conservar, mas também desincentivos para consumir maiores quantidades de energia elétrica.

\section{2 - Setor residencial}

A preocupação com o consumo de energia e eficiência energética no setor residencial não é um problema atual. No início dos anos 2000, artigos relacionados com o tema já haviam sido publicados (EDINGER; KAUL, 2000; HENS; VERBEECK; VERDONCK, 2001; MIRASGEDIS et al, 2002; BIRD; WÜSTENHAGEN; AABAKKEN, 2003; TANATVANIT; LIMMEECHOKCHAI; CHUNGPAIBULPATANA, 2003; PAPADOPOULOS; OXIZIDIS; KYRIAKIS, 2003; AYDINALP; UGURSAL; FUNG, 2004; HEPBASLI E OZGENER, 2004). Grande parte do crescimento do consumo de eletricidade dos países desenvolvidos desde 1974 ocorreram nos setores residencial, comercial e de serviços públicos. Embora a quantidade de eletricidade consumida na indústria aumentou entre 1974 e 2016, a participação da residência do consumo total de eletricidade foi maior (IEA, 2018). Assim, alguns fatores (ZHOU et al, 2016; GUO et al, 2016; SUBRAMANYAM et al, 2017; JIA et al, 2018) provaram reduzir o consumo de energia no setor residencial. Com base em estudos recentes, os assuntos nas quais os artigos desta revisão foram subdivididos são baseados em: incentivos financeiros, energia renovável, isolamento térmico, políticas públicas e cogeração ou produção combinada de calor e eletricidade (CHP). Todos esses tópicos serão contextualizados com base nos artigos selecionados para este artigo de revisão e os resultados serão apresentados resumidamente nos parágrafos a seguir.

\section{3 - Incentivos financeiros}

O fator que mais obteve medidas de economia de energia foi o de incentivo financeiro, no qual foram selecionados 18 estudos. Quando se tem uma política relativamente nova de avançar rumo a um curso mais sustentável, a aplicação disso é extremamente desafiadora e, como esperado, o fator mais importante seria o incentivo financeiro, já que é um aspecto que impacta diretamente todos os cidadãos.
Entre os assuntos mais comentados dos incentivos financeiros, a demanda de energia se destaca como o mais comentado. A demanda de energia residencial e seus determinantes são muito importantes para os economistas e formuladores de políticas, o uso e desenvolvimento de estudos agregadas para entender o consumo de energia doméstica tem aumentado desde a crise energética da década de 1970 (SALARI e JAVID, 2016). Na análise qualitativa, os dois primeiros artigos selecionados examinam a demanda de energia no setor residencial nos EUA em nível estadual. Os resultados demonstram como uma porcentagem maior de aumento no preço da eletricidade em cada estado está associada à maior redução residencial de eletricidade. Os modelos de estudo poderiam ser usados por formuladores de políticas estaduais ou regionais para otimizar seus investimentos em maiores reduções na demanda de energia residencial (VIANA; MANASSERO; UDAETA, 2018; SALARI e JAVID, 2016).

Ainda na análise da demanda, oito estudos (PON, 2017; JAYASHREE; VENKATESSH; THIRUMAL, 2016; TALENT e DU, 2018; ALBERINI E FILIPPINI, 2018; MARTINEZ-PABON; EVELEIGH; TANJU, 2018; ERYILMAZ e GAFFORD, 2018; SAJJAD et al, 2018; AHN; CHUNG; CHO, 2018) abordaram que os modelos de negócios atuais acomodam as concessionárias mais do que os clientes. A medição líquida é um fator fundamental para as redes inteligentes e é vital para as metas dos futuros, em contrapartida os sistemas de energia beneficiaria muito os clientes e a geração local.

O feedback de informação em tempo real combinado com vários esquemas de preços foi encontrado para reduzir o consumo de energia residencial mais do que apenas as políticas de informação e preços. Os programas relacionados à demanda baseados em preços provaram sua significância para atender à maior flexibilidade de demanda entre os clientes residenciais, mostrando que o impacto financeiro dessa eficiência pode ser bastante relevante.

O subsídio foi outro tópico abordado na classificação, sendo encontrados três artigos. Os subsídios aos preços diminuem o custo inicial de investimento de aparelhos eficientes em termos energéticos e também reduzem os riscos, facilitando assim a difusão de tecnologias energeticamente eficientes. Em um dos estudos, os autores comentam que, ao contrário das políticas que regulam os fornecedores, os subsídios aos preços direcionados aos consumidores poderiam aliviar ou eliminar as barreiras à promoção de aparelhos eficientes em termos energéticos. Consequentemente, uma política de subsídios que promova políticas eficientes em termos energéticos poderia ser direcionada. Verificou-se também que os subsídios para os sistemas de energia fotovoltaica têm um impacto significativo na rentabilidade (JIA et al, 2018; KRARTI e DUBEY, 2018; SIMOLA et al, 2018).

Para analisar projetos de economia de energia, a viabilidade econômica é importante. Com este tema, foram analisados três artigos (TADEU et al, 2018; CANALE et al, 2018; AKIZU et al, 2018. Para os autores, a correlação entre as taxas de descontos adotadas e a estimativa do preço da energia é crucial para a viabilidade do investimento em medidas de eficiência energética. Se as taxas de desconto fossem reduzidas, um retorno razoável do investimento seria mais aceitável. Isso confirma que as linhas de crédito com taxas de juros mais baixas podem incentivar o investimento 
em medidas de modernização e eficiência energética que tenham menor impacto no meio ambiente. E, finalmente, os dois artigos assumiram uma redução nas necessidades de energia com estudos de viabilidade.

Sistemas de baterias residenciais e comerciais estão cada vez mais sendo implantadas para armazenamento local do excesso de energia produzida (LITJENS; WORRELL; VAN SARK, 2018). O único artigo que abordou o assunto comenta que sistemas de baterias destinadas a aumentar o autoconsumo não são constantemente colocadas em uso. Este estudo avaliou os benefícios para sistemas de baterias fotovoltaicas residenciais e comerciais, combinando armazenamento de energia fotovoltaica para maior autoconsumo com provisão de reservas de restauração de frequência. Além disso, afirma que os preços das reservas de eletricidade e de restauração de frequência mostram uma alta influência na lucratividade dos sistemas de armazenamento, mas os modelos para prever os preços precisam de maior precisão.

\section{4 - Energia renovável}

A energia renovável foi o segundo tema mais abordado na pesquisa. A utilização de tecnologias de energia renovável é limpa porque se caracteriza na não produção de ruído ou poluição, classificando-se como um assunto não mais adicional, mas essencial para a busca do desenvolvimento sustentável. A utilização de recursos renováveis pode ajudar a equilibrar ou negar a crise que atualmente envolve o mundo, já que os recursos renováveis também oferecem riscos mínimos em relação ao bem-estar do meio ambiente. Existem diferentes fontes de energia renovável, como eólica, solar, biomassa, geotérmica, biocombustíveis e outras (AKIZU et al, 2018).

Dos 16 artigos sobre fonte de energia renovável, 9 lidam com sistemas fotovoltaicos. O consumo de energia no setor residencial oferece uma importante oportunidade para a implementação de propostas para aumentar a eficiência energética. Dado que os maiores benefícios são obtidos com a adoção da energia solar, conclui-se que é necessário um passo claramente significativo para promover verdadeiramente o uso destas fontes renováveis. O cálculo do desempenho energético baseia-se na abordagem de otimização, racionalização e economia de energia. Isso leva em consideração os perfis de energia de residências, dados reais e condições meteorológicas. Os resultados mostram claramente que o uso de energia economizada e o sistema fotovoltaico conectado à rede permite um balanço anual de eletricidade positivo. Uma observação interessante de alguns dos autores foi que dado que até recentemente este setor era em grande parte desregulamentado e descontrolado, estudos como esse ajudam a entender que mais ações são necessárias nesse setor, que já começa a se desdobrar nos últimos anos. No entanto, o governo deve fornecer subsídios e introduzir programas de incentivo para motivar o uso de energia solar em edifícios residenciais, por exemplo (ALVARADO; CAMPOS; TRONCOSO, 2016; LAIB et al, 2018; CALERO et al, 2018; FITRIATY E SHEN, 2018; PETIDIS et al, 2018; DUGAY et al, 2018; ENTERIA; AWBI; YOSHINO, 2015; ABD-UR-REHMAN et al, 2018; VIEIRA; MOURA; ALMEIDA, 2017).

O segundo assunto mais discutido dentro do tema energia renovável foi de aquecimento solar para residências (CIAMPI; ROSATO; SIBILIO, 2018; BIANCO; SCARPA; TAGLIAFICO, 2017; ŞERBAN et al, 2016; EL-
GHETANY e HUSSEIN, 2016; RAZAVI; AHMADI; ZAHEDI, 2018; MA et al, 2018). Sistemas de aquecimento solar de água pode fornecer uma parte significativa da energia térmica que é necessário no setor residencial. O uso de sistemas solares de aquecimento de água é motivado pelo desejo de reduzir o consumo de energia e, especialmente, para reduzir a principal fonte de emissões de gases do efeito de estufa. A opinião dos autores é que a utilização de bombas de calor e ar para aquecimento de edifícios é uma das opções mais simples e baratas de implementar a fim de promover a economia de energia. Em particular, a promoção da utilização de bombas de calor já instaladas em muitas habitações para o ar condicionado pode permitir obter resultados significativos em termos de poupança de energia primária. Eles também declaram que uma avaliação econômica e ambiental deve ser feita para descobrir a melhor economia e o menor impacto ambiental adverso.

E, finalmente, a biomassa foi o terceiro assunto abordado, mas com apenas um estudo (LAS-HERASCASAS et al, 2018). No setor residencial, a biomassa oferece grande potencial para atingir os objetivos da estratégia de clima e energia. Como a substituição de caldeiras por caldeiras mais eficientes e um maior uso de energia renovável. Além disso, as caldeiras de biomassa representam uma economia considerável ao longo da vida útil da instalação, apesar do grande investimento necessário.

\section{5 - Isolamento térmico}

O investimento na forma de isolamento térmico é importante para a sustentabilidade do setor da construção. Este investimento traz benefícios econômicos, ambientais e sociais tangíveis (ADAMCZYK e DYLEWSKI, 2017). Este assunto foi o terceiro mais abordado na análise e doze artigos foram obtidos para a classificação (RHODES et al, 2016; AMANI, 2018; BOJIĆ; CVETKOVIĆ; BOJIĆ, 2017; SOSA; CORREA; CANTÓN, 2018; JAIN; PATHAK, 2018; SGHIOURI et al, 2018; MOHAMMADI et al, 2018; HAMA, 2018; REN E CHEN, 2018; PETIDIS et al, 2018).

$\mathrm{O}$ isolamento térmico do edifício contribui diretamente para reduzir o consumo de recursos energéticos, reduzindo a demanda por energia térmica. $\mathrm{O}$ aspecto de melhorar a qualidade das condições na residência também é importante no contexto da construção sustentável. No estágio atual de desenvolvimento da economia, considera-se que deve ser prioritário buscar economia de energia ou calor para poder atender às necessidades da sociedade sem a necessidade de aumentar a produção desses tipos de energia (ADAMCZYK e DYLEWSKI, 2017).

Em um dos estudos (KIM e MOON, 2018) os autores desenvolveram um novo algoritmo de controle que integra e opera sistemas de ar-condicionado, ventilação e umidificação, considerando o ambiente externo e garantindo conforto térmico interno e economia de energia em cada status de ocupação. Em outro estudo com o tema, Pan et al (2018) verificaram que a taxa de reação térmica pode ser usada como um fator para avaliar a eficácia dos esforços de economia de energia de diferentes tipos de isolamento térmico.

\section{6 - Políticas públicas}

As características econômicas do setor elétrico exigem a adoção de políticas de incentivo para promover as inovações tecnológicas no domínio da evolução da 
eletricidade (DANTAS et al, 2018). As dinâmicas envolvidas são difíceis de prever e surgem novos desafios na concepção de medidas adequadas para fornecer informações as partes interessadas do sistema de energia elétrica, para orientar as prioridades de investimento, estabelecer os riscos e fornecer orientação na concepção de políticas e quadro regulamentar (SOARES et al, 2018). Simulações de política indicam que racionalizar o instrumento de preços de energia é uma garantia importante para o desenvolvimento sustentável e são eficazes na redução do consumo de eletricidade residencial.

As políticas públicas de energia são o quarto assunto classificado na pesquisa. A base dos dez estudos encontrados classifica-se em como as políticas e regulamentos podem interferir positivamente na redução do consumo de energia residencial (CHARLIER; RISCH; SALMON, 2018; ROJO; FISSORE; HERDE, 2018; KINDAICHI et al, 2016; MIAO, 2017; GUO et al, 2016; IVY-YAP e ALI BEKHET, 2016; SUN E OUYANG, 2016; OLONSCHECK et al, 2015; ESTIRI, 2015). Um dos artigos chamou a atenção pela política de limite de energia para desacelerar seu rápido crescimento no consumo de energia, liberar a crescente pressão sobre sua segurança energética e controlar as emissões de gases do efeito estufa. Os autores ainda comentam que a política de limite de energia não vai atrapalhar o desenvolvimento econômico ou prejudicar o consumo no setor residencial (WANG et al, 2018).

\section{7 - Cogeração e combinação de calor e energia}

O sistema de cogeração (CHP) é uma das maneiras de economizar energia e usar a energia de forma eficiente. Quando comparada com a geração de calor e eletricidade separados, alimentada por combustíveis fósseis, a cogeração pode resultar em uma conservação de energia consistente (normalmente variando de $10 \%$ a 30\%). Esta eficiência também resulta em economia de custos, reduz a poluição do ar e as emissões de gases de efeito estufa, aumenta a confiabilidade da energia e qualidade, reduz o congestionamento da rede e evita perdas na distribuição. Ao todo, sistemas de cogeração contribuem para o uso sustentável da energia direta ou indiretamente, de maneiras diferentes com vários métodos de aplicação (ÇAKIR; ÇOMAKLI; YÜKSEL, 2012; LIU; SHI; FANG, 2014).

Neste último tópico analisado, quatro estudos foram classificados para este artigo de revisão. Ozawa e Kudoh (2018) avaliaram os efeitos da aplicação de sistemas FCCHP movidos a gás de cidade a famílias japonesas com diferentes atributos. Custos totais e emissões de GEE para uso residencial de energia entre os sistemas FC-CHP e um sistema convencional foram comparados. Este estudo avaliou os desempenhos dos sistemas residenciais de FCCHP para famílias pequenas e famílias de idosos e descobriu que o desenvolvimento e a implantação de FCCHPs de baixo rendimento podem proporcionar tantas economias de custo quanto redução de emissões de GEE. Gugul et al (2018) analisaram a viabilidade técnicoeconômica da aplicação de uma ampla gama de medidas de eficiência energética e tecnologias de energia renovável para residências unifamiliares usando dados de consumo de energia monitorados e programa de simulação de energia predial. Com o estudo, obteve se uma redução na demanda de energia. Vishwanathan et al (2018) também aplicaram um estudo de análise econômica no setor residencial dos EUA e os autores concluíram que através de uma análise técnico-econômica sistemática (TEA) a alta eficiência (por exemplo, 30-40\% de combustível para eletricidade) de baixo custo (de preferência menos de US \$2.500 de preço instalado) e as baixas emissões são requisitos fundamentais para permitir a implantação generalizada de sistemas de cogeração no setor residencial dos EUA. E no último artigo classificado (MARRASSO et al, 2018), os autores analisam um sistema de micro cogeração usado para satisfazer as demandas de eletricidade, aquecimento de espaço e água quente doméstica de dois edifícios residenciais separados, localizados na Espanha, em uma abordagem de compartilhamento de carga. Os resultados deste estudo mostram que a introdução de um sistema de micro cogeração na abordagem de compartilhamento de carga leva a benefícios energéticos ambientais e econômicos.

\section{DISCUSSAO}

Nesta revisão, o maior número de medidas de economia de energia foi encontrado para incentivos financeiros. Uma razão para isso pode ser que, embora a resposta à demanda seja uma forma muito eficaz em termos de redução de demanda, gerenciamento de risco e confiabilidade, redução de emissão de carbono e redução de custos de energia o setor residencial não é capaz de adotar a resposta da demanda tão rapidamente quanto o setor industrial, porque o foco principal do setor residencial é aumentar o nível de conforto (YAN et al, 2018). A aplicação de energias renováveis e o isolamento térmico terminaram em, respectivamente, segundo e terceiro lugar no número de medidas encontradas. Isso pode ser explicado parcialmente por sua aplicabilidade relativamente ampla. Melhoria da eficiência energética através de energias renováveis e isolamento térmico são importantes no que diz respeito a vários aspectos, como preocupações ambientais e econômicas e fortalecimento da competitividade. Como as políticas públicas de energia e eficiência energética ficaram em quarto lugar no número de medidas encontradas. Uma explicação seria a dificuldade que os governantes têm na modificação de leis e regulamentos que são direcionados aos combustíveis fósseis ou até mesmo a questão econômica de não perder lucratividade. E, finalmente, as medições combinadas de calor e energia (CHP) e cogeração foram as menos encontradas. Como a política de redução de resíduos é uma preocupação relativamente nova, esses tipos de medidas ainda estão em desenvolvimento.

Além disso, os resultados deste artigo concluíram que a energia é um insumo essencial para o crescimento econômico mundial. No entanto, cada vez mais pesquisas sugerem que há efeito rebote entre eficiência e consumo de energia, o que indica que o aumento da eficiência energética também estimulará o crescimento do consumo de energia. $\mathrm{O}$ aumento da eficiência energética implica em maior nível de produção, o custo de produção e o preço do produto diminuirão, o que, por sua vez, facilitará o consumo e a produção de energia. Portanto, um modelo de crescimento econômico ideal é aumentar a produtividade e diminuir o consumo de energia simultaneamente (MARDANI et al, 2017).

\section{CONCLUSAO}

No total, foram identificadas 60 medidas de economia de energia, das quais a maioria eram de incentivos financeiros e a aplicação de energias renováveis. Isso pode ser explicado porque qualquer projeto de economia de 
energia considera o fator custo como um dos principais aspectos. Em muitos casos, as medidas apresentadas podem ser combinadas para se obter uma porcentagem maior de economia. No entanto, poucos artigos e estudos foram encontrados combinando tais medidas. As políticas recomendadas pela nossa pesquisa para a mitigação do consumo de energia residencial são as seguintes:

1. As medidas para economizar energia usando fontes de energia renováveis foram as mais econômicas em termos percentuais.

2. Os sistemas combinados de calor e energia (CHP) têm um alto potencial de desempenho para o setor.

3. O fator mais abordado foi o de incentivo financeiro, pois é um aspecto que impacta diretamente todos os cidadãos.

4. O isolamento térmico contribui diretamente para reduzir o consumo de recursos energéticos e reduzir a demanda por energia térmica.

Observou-se que a maioria dos estudos se concentra no setor industrial, em que também tem uma grande participação no consumo de energia. Isso pode explicar o baixo número de artigos encontrados na classificação focados no setor residencial. A implementação de estudos de economia de energia focados no setor residencial será uma das futuras sugestões de pesquisa desta revisão. Uma tendência identificada foi o crescimento na adoção de tais medidas de economia de energia, especialmente em 2018. No entanto, para alcançar uma mudança relevante e com aspectos socioeconômicos, espera-se políticas e regulamentações energéticas mais dominantes.

\section{REFERÊNCIAS}

ABD-UR-REHMAN, H.M.; AL-SULAIMAN, F.A.; MEHMOOD, A.; SHAKIR, S.; UMER, M. The potential of energy savings and the prospects of cleaner energy production by solar energy integration in the residential buildings of Saudi Arabia. J. Clean. Prod., v. 183, p. 11221130, 2018.

ADAMCZYK, J.; DYLEWSKI, R. The impact of thermal insulation investments on sustainability in the construction sector. Renew. Sustain. Energy Rev., v. 80, p. 421-429, 2017.

AHN, J.; CHUNG, D.H.; CHO, S. Energy cost analysis of an intelligent building network adopting heat trading concept in a district heating model. Energy, v. 151, p. 11$25,2018$.

AKIZU, O.; BUENO, G.; BARCENA, I.; KURT, E.; TOPALOĞLU, N.; LOPEZ-GUEDE, J.M. Contributions of bottom-up energy transitions in Germany: A case study analysis. Energies, v. 11, 2018.

ALBERINI, A.; FILIPPINI, M. Transient and persistent energy efficiency in the US residential sector: evidence from household-level data. Energy Effic., v. 11, p. 589-601, 2018.

ALVARADO, R.G.; CAMPOS, P.; TRONCOSO, L. Residential solar energy potential for public dissemination: A case study in concepción. Journal of Green Building, v. 11, p. 118-133, 2016.

AMANI, N. Building energy conservation in atrium spaces based on ECOTECT simulation software in hot summer and cold winter zone in Iran. Int. J. Energy Sect. Manag., v. 12, p. 298-313, 2018.

ANTONAKAKIS, N.; CHATZIANTONIOU, I.; FILIS, G. Energy consumption, CO2emissions, and economic growth: An ethical dilemma. Renew. Sustain. Energy Rev., v. 68, p. 808-824, 2017.

AYDINALP, M.; UGURSAL, V.I. Fung AS. Modeling of the space and domestic hotwater heating energyconsumption in the residential sector using neural networks. Appl. Energy, v. 79, p. 159-178, 2004.

BIANCO, V.; SCARPA, F.; TAGLIAFICO, L.A. Estimation of primary energy savings by using heat pumps for heating purposes in the residential sector. Appl. Therm. Eng., v. 114, p. 938-947, 2017.

BIRD, L.; WÜSTENHAGEN， R.; AABAKKEN，J. A review of international green power markets: recent experiences, trends, and market drivers. Fuel Energy Abstr., v. 44, 2003.

BOJIĆ, M.; CVETKOVIĆ, D.; BOJIĆ, L. Optimization of geometry of horizontal roof overhangs during a summer season. Energy Effic., v. 10, p. 41-54, 2017.

ÇAKIR, U.; ÇOMAKLI, K.; YÜKSEL, F. The role of cogeneration systems in sustainability of energy. Energy Convers. Manag., v. 63, p. 196-202, 2012.

CALERO, M.; ALAMEDA-HERNANDEZ, E.; FERNÁNDEZ-SERRANO, M.; RONDA, A.; MARTÍNLARA, M.A. Energy consumption reduction proposals for thermal systems in residential buildings. Energy Build., v. 175, p. 121-130, 2018.

CANALE, L.; DELL'ISOLA, M.; FICCO, G.; DI PIETRA, B.; FRATTOLILLO, A. Estimating the impact of heat accounting on Italian residential energy consumption in different scenarios. Energy Build., v. 168, p. 385-398, 2018.

CHARLIER, D.; RISCH, A.; SALMON, C. Energy Burden Alleviation and Greenhouse Gas Emissions Reduction: Can We Reach Two Objectives With One Policy? Ecol. Econ., v. 143, p. 294-313, 2018.

CIAMPI, G.; ROSATO, A.; SIBILIO, S. Thermo-economic sensitivity analysis by dynamic simulations of a small Italian solar district heating system with a seasonal borehole thermal energy storage. Energy, v. 143, p. 757-771, 2018.

DANTAS, G.A.; CASTRO, N.J.; DIAS, L.; ANTUNES, C.H.; VARDIERO, P.; BRANDÃO, R.; ROSENTAL, R.; ZAMBONI, L. Public policies for smart grids in Brazil. Renew. Sustain. Energy Rev., v. 92, p. 501-512, 2018.

DUGAY, K.D.; LUISAGA, A.Z.; ANGELO, J.; BANCUD, C.O. Microcontroller-based Control and Data Acquisition System for a Grid-connected Renewable Energy System. Telkomnika, v. 16, p. 1481-1489, 2018.

EDINGER, R.; KAUL, S. Humankind's detour toward sustainability: Past, present, and future of renewable energies and electric power generation. Renew. Sustain. Energy Rev., v. 4, p. 295-313, 2000.

EL-GHETANY, H.H.; HUSSEIN, H.M.S. Study of energy and water conservation in a residential compound in Egypt. 
International Journal of Applied Engineering Research, v. 11, p. 7846-7850, 2016.

ENTERIA, N.; AWBI, H.; YOSHINO, H. Application of renewable energy sources and new building technologies for the Philippine single family detached house. Int. J. Energy Environ. Eng., v. 6, p. 267-294, 2015.

ERYILMAZ, D.; GAFFORD, S. Can a daily electricity bill unlock energy efficiency? Evidence from Texas. Electr. J, v. 31, p. 7-11, 2018.

ESTIRI, H. A structural equation model of energy consumption in the United States: Untangling the complexity of per-capita residential energy use. Energy Res. Soc. Sci., v. 6, p. 109-120, 2015.

FITRIATY, P.; SHEN, Z. Predicting energy generation from residential building attached Photovoltaic Cells in a tropical area using 3D modeling analysis. J. Clean. Prod., v. 195 , p. $1422-1436,2018$.

FOSSATI, M.; SCALCO, V.A.; LINCZUK, V.C.C.; LAMBERTS, R. Building energy efficiency: An overview of the Brazilian residential labeling scheme. Renew. Sustain. Energy Rev., v. 65, p. 1216-1231, 2016.

GUGUL, G.N.; AYDINALP KOKSAL, M.; UGURSAL, V.I. Techno-economical analysis of building envelope and renewable energy technology retrofits to single family homes. Energy Sustain. Dev., v. 45, p. 159-170, 2018.

GUO, F.; KURDGELASHVILI, L.; BENGTSSON, M.; AKENJI, L. Analysis of achievable residential energysaving potential and its implications for effective policy interventions: A study of Xiamen city in southern China. Renew. Sustain. Energy Rev., v. 62, p. 507-520, 2016.

HAMA, R.C. Traditional houses energy optimization using passive strategies. Pollack Periodica, v. 13, 2018.

HENS, H.; VERBEECK, G.; VERDONCK, B. Impact of energy efficiency measures on the $\mathrm{CO} 2$ emissions in the residential sector, a large scale analysis. Energy Build., v. 33, p. 275-281, 2001.

HEPBASLI, A.; OZGENER, L. Development of geothermal energy utilization in Turkey: A review. Renew. Sustain. Energy Rev., v. 8, p. 433-460, 2004

INTERNATIONAL ENERGY AGENCY. Electricity Information: Overview (2018 Edition).

IVY-YAP, L.L.; ALI BEKHET, H. Modelling the causal linkages among residential electricity consumption, gross domestic product, price of electricity, price of electric appliances, population and foreign direct investment in Malaysia. Int. J. Energy Technol. Policy, v. 12, p. 41-59, 2016.

JAIN, M.; PATHAK, K.K. Thermal modelling of insulator for energy saving in existing residential building. J. Build. Eng., v.19, p. 62-68, 2018.

JAYASHREE, L.S.; VENKATESSH, A.; THIRUMAL, A. A Novel Smart Home Energy Management System for Residential Buildings. Asian Journal of Information Technology, v. 15, p. 3793-3800, 2017.

JIA, J.J.; XU, J.H.; FAN, Y.; JI, Q. Willingness to accept energy-saving measures and adoption barriers in the residential sector: An empirical analysis in Beijing, China. Renew. Sustain. Energy Rev., v. 95, p. 56-73, 2018.

KIM, S.H.; MOON, H.J. Case study of an advanced integrated comfort control algorithm with cooling, ventilation, and humidification systems based on occupancy status. Build. Environ., v. 133, p. 246-264, 2018.

KINDAICHI, S.; NISHINA, D.; MURAKAWA, S.; MURAKAMI, S. Factor analysis on electricity conservation rates in welfare facilities - Analysis based on the results of investigation for development of the DECC. AIJ J. Technol. Des., v. 22, p. 645-650, 2016.

KRARTI, M.; DUBEY, K. Benefits of energy efficiency programs for residential buildings in Bahrain. J. Build. Eng., v. 18, p. 40-50, 2018.

LAIB, I.; HAMIDAT, A.; HADDADI, M.; RAMZAN, N.; OLABI, A.G. Study and simulation of the energy performances of a grid-connected PV system supplying a residential house in north of Algeria. Energy, v. 152, p. 445-454, 2018.

LAS-HERAS-CASAS， J.; LÓPEZ-OCHOA， L.M.; PAREDES-SÁNCHEZ， J.P.; LÓPEZ-GONZÁLEZ， L.M. Implementation of biomass boilers for heating and domestic hot water in multifamily buildings in Spain: Energy, environmental, and economic assessment. J. Clean. Prod. v. 176 , p. $590-603,2018$.

LITJENS, G. B.M.A.; WORRELL, E.; VAN SARK, W.G.J.H.M. Economic benefits of combining selfconsumption enhancement with frequency restoration reserves provision by photovoltaic-battery systems. Appl. Energy, v. 223, p. 172-187, 2018.

LIU, M.; SHI, Y.; FANG, F. Combined cooling, heating and power systems: A survey. Renew. Sustain. Energy Rev., v. 35, 2014.

MA, W.; XUE, X.; LIU, G.; ZHOU, R. Techno-economic evaluation of a community based hybrid renewable energy system considering site- pecific nature. Energy Convers. Manag., v. 171, p. 1737-1748, 2018.

MARDANI, A.; ZAVADSKAS, E.K.; STREIMIKIENE, D.; JUSOH, A.; KHOSHNOUDI, M. A comprehensive review of data envelopment analysis (DEA) approach in energy efficiency. Renew. Sustain. Energy Rev., v. 70, p. 1298-1322, 2017

MARRASSO, E.; ROSELLI, C.; SASSO, M.; PICALLOPEREZ, A.; SALA LIZARRAGA, J.M. Dynamic simulation of a microcogeneration system in a Spanish cold climate. Energy Convers. Manag., v. 165, p. 206-218, 2018.

MARTINEZ-PABON, M.; EVELEIGH, T.; TANJU, B. Optimizing residential energy management using an autonomous scheduler system. Expert Syst. Appl., v. 96, p. $373-387,2018$

MIAO, L. Examining the impact factors of urban residential energy consumption and CO2emissions in China - Evidence from city-level data. Ecol. Indic., v. 73, p. 29-37, 2017.

MIRASGEDIS, S.; SARAFIDIS, Y.; GEORGOPOULOU, E.; LALAS, D. The role of renewable energy sources within 
the framework of the Kyoto Protocol: the case of Greece. Renew. Sustain. Energy Rev., v. 6, p. 247-269, 2002.

MOHAMMADI, A.; SAGHAFI, M.R.; TAHBAZ, M.; NASROLLAHI, F. The study of climate responsive solutions in traditional dwellings of Bushehr City in Southern Iran. J. Build. Eng., v. 16, p. 169-183, 2018.

NILSSON, A.; LAZAREVIC, D.; KORDAS, O.; BRANDT, N. Household responsiveness to residential demand response strategies: Results and policy implications from a Swedish field study. Energy Policy, v. 122, p. 273 286, 2018.

OLONSCHECK, M.; WALTHER, C.; LÜDEKE, M.; KROPP, J.P. Feasibility of energy reduction targets under climate change: The case of the residential heating energy sector of the Netherlands. Energy, v. 90, p. 560-569, 2015.

OZAWA, A.; KUDOH, Y. Performance of residential fuelcell-combined heat and power systems for various household types in Japan. Int. J. Hydrogen Energy, v. 43, p. $15412-15422,2018$

PAN, L.; XU, Q.; NIE, Y.; QIU, T. Analysis of climate adaptive energy-saving technology approaches to residential building envelope in Shanghai. J. Build. Eng., v. 19, p. 266-272, 2018.

PAPADOPOULOS, A.M.; OXIZIDIS, S.; KYRIAKIS, N. Perspectives of solar cooling in view of the developments in the air-conditioning sector. Renew. Sustain. Energy Rev., v. 7, p. 419-438, 2003.

PETIDIS, I.; ARYBLIA, M.; DARAS, T.; TSOUTSOS, T. Energy saving and thermal comfort interventions based on occupants' needs: A students' residence building case. Energy Build., v. 174, p. 347-364, 2018.

PON, S. The Effect of Information on TOU Electricity Use: an Irish residential study. The Energy Journal, v. 38, p. 5579, 2017.

RAZAVI, S.H.; AHMADI, R.; ZAHEDI, A. Modeling, simulation and dynamic control of solar assisted ground source heat pump to provide heating load and DHW. Appl. Therm. Eng. v. 29, p. 127-144, 2018.

REDDY, B.S. Appliance Electricity Consumption in the Residential Sector - an Economic-Approach. Energy Sources, v. 17, p. 179-193, 1995.

REN, Z.; CHEN, D. Modelling study of the impact of thermal comfort criteria on housing energy use in Australia. Appl. Energy, v. 210, p. 152-166, 2018.

RHODES, J.D.; EL IMANE BOUHOU, N.; UPSHAW, C.R.; BLACKHURST, M.F.; WEBBER M.E. Residential energy retrofits in a cooling climate. J. Build. Eng., v. 6, p. 112-118, 2016.

ROJO, C.; FISSORE, A.; De HERDE, A. The difference between theoretical and measured energy consumption in residential heating: Chilean case. Rev. la construcción, p. 149-157, 2018.

SAJJAD, I.A.; MANGANELLI, M.; MARTIRANO, L.; NAPOLI, R.; CHICCO, G.; PARISE, G. Net Metering Benefits for Residential Customers: The Economic Advantages of a Proposed User-Centric Model in Italy. IEEE Ind. Appl. Mag., v. 24, p. 39-49, 2018.
SALARI, M.; JAVID, R.J. Residential energy demand in the United States: Analysis using static and dynamic approaches. Energy Policy, v. 98, p. 637-649, 2016.

ŞERBAN，A.; BĂRBUŢĂ-MIŞU，N.; CIUCESCU， N.; PARASCHIV, S.; PARASCHIV, S. Economic and Environmental Analysis of Investing in Solar Water Heating Systems. Sustainability, v. 8, 2016.

SGHIOURI, H.; MEZRHAB, A.; KARKRI, M.; NAJI, H. Shading devices optimization to enhance thermal comfort and energy performance of a residential building in Morocco. J. Build. Eng., v. 18, p. 292-302, 2018.

SIMOLA, A.; KOSONEN, A.; AHONEN, T.; AHOLA, J.; KORHONEN, M.; HANNULA, T. Optimal dimensioning of a solar PV plant with measured electrical load curves in Finland. Sol. Energy, v. 170, p. 113-123, 2018.

SOARES, N.; MARTINS, A.G.; CARVALHO, A.L.; CALDEIRA， C.; DU， C.; CASTANHEIRA， C.; RODRIGUES, E.; OLIVEIRA, G.; PEREIRA, G.I.; BASTOS, J.; FERREIRA, J.P.; RIBEIRO, L.A.; FIGUEIREDO, N.C.; ŠAHOVIĆ, N.; MIGUEL, P.; GARCIA, R. The challenging paradigm of interrelated energy systems towards a more sustainable future. Renew. Sustain. Energy Rev., v. 95, p. 171- 93, 2018.

SOSA, M.B.; CORREA, E.N.; CANTÓN, M.A. Neighborhood designs for low-density social housing energy efficiency: Case study of an arid city in Argentina. Energy Build., v. 168, p. 137-146, 2018.

SUBRAMANYAM, V.; KUMAR, A.; TALAEI, A.; MONDAL, M.A.H. Energy efficiency improvement opportunities and associated greenhouse gas abatement costs for the residential sector. Energy, v. 118, p. 795-807, 2017.

SUN, C.; OUYANG, X. Price and expenditure elasticities of residential energy demand during urbanization: An empirical analysis based on the household-level survey data in China. Energy Policy, v. 88, p. 56-63, 2016.

TADEU, S.; TADEU, A.; SIMÕES, N.; GONÇALVES, M.; PRADO, R. A sensitivity analysis of a cost optimality study on the energy retrofit of a single-family reference building in Portugal. Energy Effic., p. 1-22, 2018.

TALENT, O.; DU, H. Optimal sizing and energy scheduling of photovoltaic-battery systems under different tariff structures. Renewable Energy, v. 129, p. 513-526, 2018.

TANATVANIT, S.; LIMMEECHOKCHAI, B.; CHUNGPAIBULPATANA, S. Sustainable energy development strategies: Implications of energy demand management and renewable energy in Thailand. Renew. Sustain. Energy Rev., v. 7, p. 367-395, 2003.

VIANA, M.S.; MANASSERO, G.; UDAETA, M.E.M. Analysis of demand response and photovoltaic distributed generation as resources for power utility planning. Appl. Energy, v. 217, p. 456-466, 2018.

VIEIRA, F.M.; MOURA, P.S.; ALMEIDA, A.T. Energy storage system for self-consumption of photovoltaic energy in residential zero energy buildings. Renew. Energy, v. 103, p. 308-320, 2017.

VISHWANATHAN, G.; SCULLEY, J.P.; FISCHER, A.; ZHAO, J.C. Techno-economic analysis of high-efficiency 
natural-gas generators for residential combined heat and power. Appl. Energy, v. 226, p. 1064-1075.

WADA, K.; AKIMOTO, K.; SANO, F.; ODA, J.; HOMMA, T. Energy efficiency opportunities in the residential sector and their feasibility. Energy, v. 48, p. 510, 2012.

WANG, F.; LIU, X.; NGUYEN, T.A. Evaluating the economic impacts and feasibility of China's energy cap: Based on an Analytic General Equilibrium Model. Econ. Model., v. 69, p. 114-126, 2018.

YAN, X.; OZTURK, Y.; HU, Z.; SONG, Y. A review on price-driven residential demand response. Renew. Sustain. Energy Rev., v. 96, p. 411-419, 2018.

ZHOU, B.; LIA, W.; CHAN, K.W.; CAO, Y.; KUANGA, Y.; LIU, X.; WANG, X. Smart home energy management systems: Concept, configurations, and scheduling strategies.

Renew. Sustain. Energy Rev., v. 61, p. 30-40, 2016.

\section{COPYRIGHT}

Direitos autorais: Os autores são os únicos responsáveis pelo material incluído no artigo.

Submetido em: 05/11/2018

Aprovado em: 07/12/2018 


\title{
Revista SODEBRAS - Volume 14 $\mathrm{N}^{\circ} 157$ - JANEIRO/ 2019
}

\section{PRODUÇÃO DE SYNGAS E SEU USO NA GERAÇÃO DE ENERGIA: UMA REVISÃO}

\author{
SYNGAS PRODUCTION AND ITS POWER GENERATION USE: \\ A REVIEW
}

\author{
DIOGO THEODORO LAGO ${ }^{1}$, TEÓFILO MIGUEL DE SOUZA ${ }^{1}$, LUIZ CARLOS BEVILAQUA DOS \\ SANTOS REIS ${ }^{2}$, JOÃO ANDRADE DE CARVALHO JÚNIOR ${ }^{1}$ \\ 1 - UNIVERSIDADE ESTADUAL PAULISTA JÚLIO DE MESQUITA FILHO; 2 - UNIVERSIDADE \\ ESTADUAL DO RIO DE JANEIRO \\ diogotlago@gmail.com;teofilo_miguel@yahoo.com.br;bevilaqua@gmail.com; joao@feg.unesp.br
}

\begin{abstract}
Resumo - As pesquisas e projetos de fontes de energia novas e limpas estão em contínuo crescimento. Os processos de produção, geração de energia e cogeração utilizando syngas vêm demonstrando maior eficiência energética e exergética. Neste artigo, a produção de gás de síntese e seu uso de geração de energia, como as Centrais Elétricas do Ciclo Combinado de Gaseificação Integrada (IGCC), são revisados e seus respectivos resultados são mostrados. O Syngas é uma importante fonte de energia para contribuir para o desenvolvimento sustentável do planeta. Assim, a produção e os usos da expansão do gás de síntese devem ser ampliados, mesmo que ainda existam questões técnicas e governamentais a serem resolvidas.
\end{abstract}

Palavras-chave: Syngas. Gaseificação. Energia. Eficiência.

\begin{abstract}
The research and projects regarding new and clean energy sources are in continuous growth. The processes of production, power generation and cogeneration using syngas has been demonstrating increased efficiency energy and exergy. In this article, syngas production and its power generation use, such as Integrated Gasification Combined Cycle (IGCC) Power Plants, are reviewed and their respective results are shown. Syngas is an important energy source to contribute for the planet sustainable development. Thus, syngas expansion production and uses should be expanded even if there still are technical and government questions to be solved.
\end{abstract}

Keywords: Syngas. Gasification. Energy. Efficiency.

\section{INTRODUÇÃO}

Existem várias pesquisas e projetos ligados a geração de energia limpa para reduzir a emissão de gases de efeito estufa e o syngas pode ser um combustível contribuinte, quando oriundo de uma fonte renovável como a biomassa. Mas o syngas pode ser também um combustível oriundo de uma fonte de combustível não renovável, como o carvão (o mais utilizado devido a suas grandes reservas disponíveis (OH et al., 2018)).

Suas formas mais comuns de produção são: a gaseificação e a fermentação.

A gaseificação pode ser a ar ou a vapor. Em ambas as formas, os indicadores operacionais, tais como a relação vapor / biomassa, deposição de carbono e temperatura são componentes que influenciam na eficiência do processo.
Em um modelo de gaseificação a vapor, o aumento da temperatura aumenta a concentração de $\mathrm{H}_{2}$ no syngas formado por exemplo. A partir de uma temperatura de $800^{\circ} \mathrm{C}$, considerando um processo de gaseificação a vapor, a composição química do syngas permanece estável, como pode ser ilustrado na Figura 1 (COZZOLINO et al. 2017).

Mas a concentração de hidrogênio pode aumentar com o aumento da razão vapor / biomassa de gaseificação (PALA et al., 2017).

$\mathrm{O}$ poder calorífico inferior do syngas formado a uma temperatura de $500^{\circ} \mathrm{C}$ é cerca de $2.250 \mathrm{kcal} / \mathrm{m}^{3}$, com massa específica de $0,79 \mathrm{~kg} / \mathrm{m}^{3}$ e uma relação ar / gás para combustão estequiométrica de 2,33. O syngas formado a uma temperatura de $900^{\circ} \mathrm{C}$ possui cerca de $2.530 \mathrm{kcal} / \mathrm{m}^{3}$, com massa específica de $0,59 \mathrm{~kg} / \mathrm{m}^{3}$ e uma relação ar / gás para combustão estequiométrica desta composição de 2,18 (valores nas condições normais de temperatura e pressão).

Figura 1 - Composição química do syngas (considerando taxa fixa de 0,6 da relação vapor / biomassa)

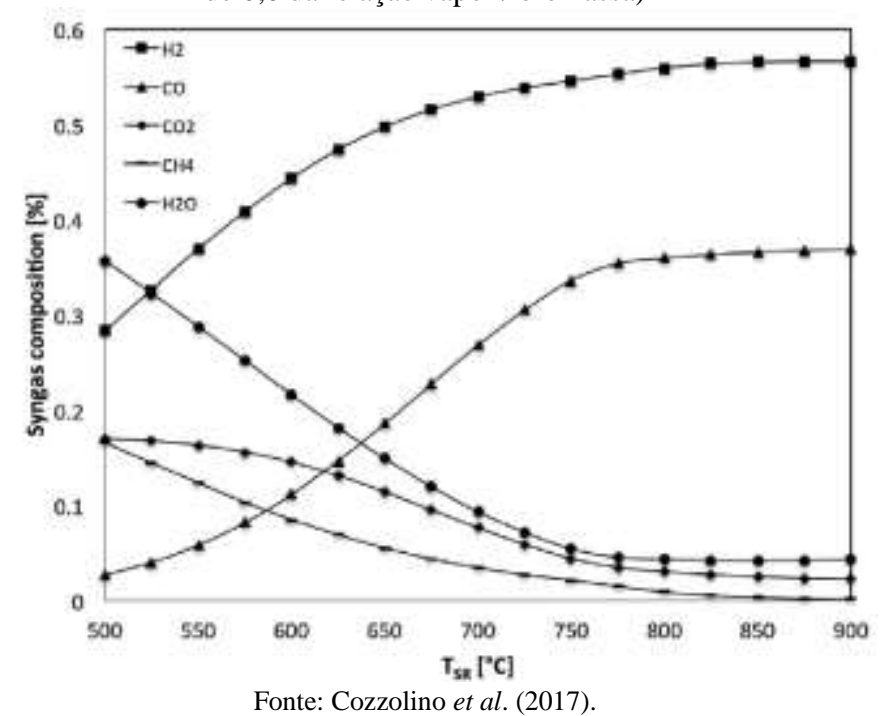

Para determinar a composição típica de syngas a ser produzido, deve-se analisar a origem da matéria-prima. No caso da biomassa, essa pode ser originada de: cascas de café, esterco de vaca, resíduos verdes, resíduos alimentares, 
resíduos sólidos urbanos, serragem de pinho, resíduos de madeira e lascas de madeira (PALA et al., 2017).

Pesquisas mostram que o melhor índice de desempenho entre as matérias-primas para produção do syngas são os resíduos da indústria de papel. Em relação a quantidade de água na biomassa, o esterco de vaca e os resíduos da produção de café são aqueles com menor percentual de umidade. Isso não significa dizer que a melhor eficiência em termos de calor e potência final são garantidas por uma boa quantidade de matéria-prima para a produção de syngas (PRAKASH et al., 2017).

A gaseificação a ar por leito fixo, pode trazer benefícios financeiros por cada $\mathrm{kg}$ de matéria-prima. Estes benefícios ao processo são máximos quando a taxa de ar por biomassa é de 0,25 (YAO et al., 2018).

A fermentação seria um processo alternativo para uma maior formação de syngas, sendo o bioetanol a matériaprima mais representativa para conversão através de sua biomassa residual. Contudo, o baixo rendimento de produção e a perda de componentes do syngas, como o $\mathrm{H}_{2}$ e o CO, gerou entraves para sua aplicação em plantas de escala industrial (ASIMAKOPOULOS et al., 2018).

Não somente as formas de obtenção do syngas têm sido pesquisadas, mas também as matérias-primas alternativas para o sistema de produção. A utilização de algas, por exemplo, pode alcançar alta eficiência de geração de energia como combustíveis e sugerem que estas podem substituir o uso atual de gás natural e carvão no processo de gaseificação (ZAINI et al., 2017).

As pesquisas realizadas mesmo em plantas existentes, como alternativa para economizar o consumo de combustível, como por exemplo o carvão, e mitigar as emissões de $\mathrm{CO}_{2}$ oriundas do processo de queima em combinação com plantas futuras também refletem resultados positivos tanto em disponibilidade como em economia, prevendo-se, em algumas configurações, possíveis perdas de eficiência da planta existente (FORMAN et al., 2017).

Sistemas híbridos também trazem avanços em eficiência energética e na produção de energia limpa, exemplo, uma planta híbrida com uma micro turbina a gás (MGT) e uma célula a combustível de óxido sólido (SOFC). Esta possui viabilidade a curto e médio prazo aplicando-se na operação com syngas como combustível, sendo este gerado por um gaseificador de corrente de biomassa (BG) (PERNA et al., 2017).

A captura de $\mathrm{CO}_{2}$ é um processo secundário que pode ser aplicado a geração de energia em plantas de ciclo combinado de gaseificação integrada que processam biomassa, onde o sistema de gaseificação é feito com ar. Essa captura pode ocorrer por absorção química, o que ambientalmente reflete em benefício mas podem vir a reduzir a eficiência global das plantas (DINCA et al., 2018).

Algumas simulações também mostram confiabilidade para aplicação do processo de gaseificação. As variáveis termodinâmicas dos processos (velocidade frontal da chama, taxa de consumo de biomassa, fluxo de gás volumétrico, valor de aquecimento a gás, razão de equivalência e eficiência de gás frio) possuem um erro relativo médio abaixo de 6\% (GONZÁLEZ et al., 2018).

Não somente as oportunidades de aplicação e geração de energia através do syngas são partes das pesquisas atuais. Outras pesquisas ainda ilustram que existem questões importantes a serem consideradas nas implantações e operações (SANSANIWAL et al., 2017), tais como: a caracterização da biomassa tem influência no comportamento e na forma de conversão. Ainda assim, devem ser verificados as formas para colheita, coleta, transporte e armazenamento do combustível, por exemplo a biomassa; o pré-tratamento da biomassa (secagem, densificação e moagem), pois necessita de energia e trabalho para processamento; a própria gaseificação é um processo complexo que depende dos indicadores operacionais (temperatura, razão ar / biomassa ou vapor / biomassa, teor de umidade, entre outros) e sua eficiência fica reduzida no caso de utilização de pirólise para redução da umidade, tornando-o ainda instável; o condicionamento do syngas algumas vezes requer um aperfeiçoamento do reator, um controle ótimo dos indicadores operacionais para redução da formação do alcatrão; e o sistema de limpeza também deve ser eficaz para que sejam removidas as cinzas e outras impurezas do syngas produzido. Além disso, questões como incentivos e políticas governamentais, como logística, integração social, mão de obra qualificada e modificações nos equipamentos existentes para adaptação ainda necessitam de mais interesse e desenvolvimento (SANSANIWAL et al., 2017).

A utilização eficiente de biomassa para produção de syngas oferece oportunidade em eficiência energética, contribui para o meio ambiente, para economia e para a sociedade (KAUSHAL; TYAGI, 2017).

A produtividade não somente das industrias, como também na aplicação do uso nas áreas rurais, podem vir a incentivar a criação de novas cadeias de fornecimento de matéria-prima de biomassa.

$\mathrm{O}$ aumento das atividades industriais e o crescimento populacional demandam a necessidade de descobertas para utilização de fontes alternativas de energia com menores impactos ambientais (ASLANI et al., 2018).

A Europa já possui mais de 17.000 plantas de geração de energia elétrica que utilizam biogás instaladas e tem uma capacidade total de mais de $10 \mathrm{GW}$, em comparação com uma capacidade global de geração de energia elétrica por esta matriz energética que é de $16 \mathrm{GW}$ (SCARLAT et al., 2018).

Em muitos casos, o crescimento dessa matriz energética reduz a dependência do uso de gás natural, que também tem seu uso para fins comerciais, domésticos e outros sistemas industriais (ALEMANY et al., 2010).

\section{PRODUÇÃO DE SYNGAS E AS PLANTAS DE CICLO COMBINADO COM GASEIFICAÇÃO INTEGRADA}

A produção de syngas é diretamente influenciada pela variação da temperatura. Uma geração maior da quantidade de energia poderá ser maior com o aumento da temperatura de formação, quando a relação $\mathrm{CH}_{4} / \mathrm{CO}_{2}$ ou $\mathrm{C} / \mathrm{CO}_{2}$ aumentam. Essas conversões são independentes da pressão. Recomenda-se temperaturas de reação superiores a $500^{\circ} \mathrm{C}$ para obter uma conversão menor de dióxido de carbono e maiores rendimentos de hidrogênio e monóxido de carbono (CHEIN; HSU, 2018).

O syngas produzido a partir do gaseificador de leito fixo sofre de elevados diluentes inertes $\left(\mathrm{N}_{2}+\mathrm{CO}_{2}\right)$ na faixa de 60 e $65 \%$ em volume. Assim, é necessária uma maior energia para a compressão externa do syngas (AL-ATTAB; ZAINAL, 2018).

O compressor de uma microturbina a gás foi usado para elevar a pressão da mistura syngas-ar, e assim, eliminar 
a necessidade de qualquer equipamento de resfriamento e compressão do syngas. Esse processo reduz consideravelmente o custo de operação e manutenção da produção do syngas.

$\mathrm{O}$ gaseificador tem eficiência máxima de cerca de $86 \%$. A temperatura de entrada da turbina deve estar abaixo de $700^{\circ} \mathrm{C}$, assim, a eficiência total do sistema é de $37,8 \%$.

A utilização de energia limpa na produção de eletricidade não é a única motivação para surgimento de projetos e pesquisas ligados a este tema. Os preços da energia no mercado e variação da demanda de energia elétrica também impulsionam estes trabalhos.

As plantas de ciclo combinado com gaseificação integrada (IGCC, termo em Inglês), podem operar com eficiência energética utilizando um combustível ou mesmo dois, queimando carvão com biomassa por exemplo, comumente produzindo o syngas como combustível (SHEIKH et al., 2018). Além disso, podem operar na forma de cogeração produzindo vapor, metano, amônia, entre outros produtos (SHEIKH et al., 2018; SOLARTE-TORO et al., 2018). A Figura 2 ilustra um esquemático resumido de uma planta de ciclo combinado com gaseificação integrada (IGCC).

Figura 2 - Fluxograma simplificado de uma planta de ciclo combinado com gaseificação integrada - IGCC

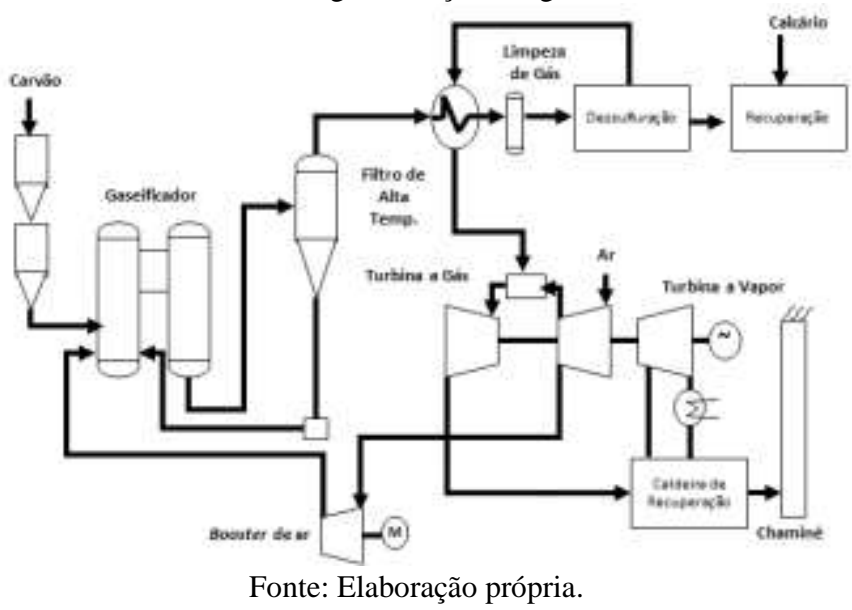

Os custos de produção do syngas são menores que os custos de produção do biogás o que o torna atrativo a investimentos. Contudo, o biogás pode ter um maior poder calorífico, podendo alcançar maiores produções e gerações de energia (SOLARTE-TORO et al., 2018).

Somente operando para produção de energia elétrica, pesquisas mostram que a eficiência global de planta de ciclo combinado com gaseificação integrada (IGCC) é de cerca de $33 \%$ (SHEIKH et al., 2018), podendo chegar a $43 \%$ (DESCAMPS et al., 2008). Mas aumentando a produção de coprodutos a eficiência energética diminui (DESCAMPS et al., 2008; SHEIKH et al., 2018).

No sistema de limpeza de gás, durante o resfriamento rápido do syngas e o não aproveitamento do calor exaurido por este processo, as perdas podem significar $7 \%$ na eficiência líquida, por exemplo. Um aumento de temperatura na ordem de $50{ }^{\circ} \mathrm{C}$ pode causar uma redução de 0,4\% na eficiência líquida do sistema (HAN et al., 2018).

A geração de energia em plantas de ciclo combinado com gaseificação integrada é o processo atual mais importante para reduzir as emissões de $\mathrm{CO}_{2}$ sem grande penalidade na eficiência térmica (KOBAYASHI; AKIHO,
2017), podendo fornecer dióxido de carbono comprimido $\left(\mathrm{CO}_{2}\right)$ com concentração de $93 \%$ em volume. Outra vantagem ligada ao IGCC é a geração de energia utilizando o processo oxicombustão que pode atingir uma eficiência térmica de cerca de $44 \%$.

A geração de energia utilizando biomassa oriunda do setor agrícola para conversão de energia possui alto desempenho quando o sistema de conversão utiliza de forma combinada a digestão anaeróbica (fermentação) e a gaseificação. O processo é de cogeração, resultando em energia elétrica e refrigeração. Os principais equipamentos nesse sistema são: pilha de combustível de óxido sólido, turbina a gás e turbina a vapor. O menor valor obtido para aquecimento do syngas é estimado em $23,47 \mathrm{MJ} / \mathrm{kg}$ e a eficiência energética e exergética de 63,62 e 58,46\% (OGORURE et al., 2018).

Em sistema de ciclo combinado de calor e potência (resfriamento combinado, aquecimento e potência) que permite queima de dois combustíveis simultaneamente, gás natural e syngas, consegue demonstrar as diferenças da queima isolada de syngas e a queima com adição de gás natural.

A queima isolada de syngas apresenta uma eficiência energética $70,0 \%$, e uma eficiência exergética $21,9 \%$. Quando a relação da mistura volumétrica de gás natural e syngas é de 1 para 1 , as eficiências energéticas e exergética aumentam para $79,5 \%$ e $35,6 \%$, respectivamente (WANG et al., 2015).

A utilização de misturas entre biomassa e o carvão como matéria-prima, podem trazer melhores desempenhos nos sistemas de produção de syngas, e as eficiências energética e exergética deste processo proposto são de $53,19 \%$ e $50,81 \%$, respectivamente, onde a biomassa é $40 \%$ em peso. Este processo favorece uma redução de aproximadamente $16,86 \%$ do consumo de energia e $98,74 \%$ das emissões de carbono (FAN et al., 2018).

O syngas, assim como outros gases com poder calorifico inferior pobre (dependendo de sua origem), são capazes de aumentar a potência das turbinas a gás, do ciclo combinado com gaseificação integrada (IGCC) por exemplo, em relação a turbina a gás que opera utilizando gás natural como combustível. Isso ocorre por causa do menor valor de índice de Wobbe e a quantidade de componentes inertes presentes no syngas, e dessa forma, ocorre um aumento no fluxo de gás que passa pela turbina a gás. As alternativas de aplicação de plantas que utilizam syngas em alguns casos sugerem que processo de gaseificação seja parcial, afim de obter maior eficiência energética na planta (PEDROSO et al., 2017).

Considerando um ciclo combinado gás-vapor, parcialmente alimentado por syngas (produzido em um gaseificador a ar como agente gaseificador e com bagaço como matéria-prima combustível) demonstra-se que o syngas oferece uma combustão mais eficiente no que diz respeito à combustão direta da biomassa sólida, tanto em termos de geração de calor quanto de energia, eficiência térmica de $40,1 \%$ e eficiência exergética de $35,7 \%$ (DAMBROSIO et al., 2017).

Essas eficiências mostram-se competitivas quando comparadas a eficiência dos sistemas de geração que utilizam o gás natural, $46 \%$, e óleo combustível, 36,7\% (SANTOS et al., 2016). 


\section{MELHORIA DE DESEMPENHO}

Para aumentar a eficiência energética na IGCC, recomenda-se um estudo de soluções tecnológicas que contribuam com aumento de temperatura e recuperação de calor, o que sugerem-se um incremento na eficiência de 1 a $1,5 \%$ (RYZHKOV et al., 2018).

A remoção de $\mathrm{CO}_{2}$ do syngas, além de revolver os problemas ambientais, pode contribuir para maior eficiência energética na planta, usando por exemplo, quando combinando uma mistura com vapor no syngas.

O aumento de ar e vapor, no sistema de gaseificação, aumenta o poder calorífico do syngas em $10 \%$, a eficiência de conversão alcança $84,3 \%$ e eficiência líquida aumenta 0,53\% (RYZHKOV et al., 2018).

\section{COMBUSTÃO E MEIO AMBIENTE}

O sistema de gaseificação que opera com oxigênio puro é mais eficiente e tem uma maior taxa conversão de carbono em comparação com a gaseificação a ar. Além disso, como quase nenhum $\mathrm{N}_{2}$ é injetado neste tipo de processo, pouco $\mathrm{NO}_{x}$ é gerado e a captura de $\mathrm{CO}_{2}$ do syngas produzido é mais fácil do que na gaseificação a ar $(\mathrm{OH}$ et al., 2018).

Verificando o desempenho da limpeza de gás (principalmente na retirada de cinzas) e a redução das emissões de poluentes, estudos mostraram que um filtro para operação em um ambiente industrial, em caldeiras a carvão por exemplo, a maior eficiência de coleta é 87,61\% e foi obtida com uma concentração de material particulado na entrada de 15.000 ppmw em que o diâmetro dos particulados de poeira estavam entre 0,1 e 0,5 micrometros. Com uma concentração de material particulado na entrada de 3.750 ppmw, a eficiência de coleta foi de $72,01 \%$ para particulados de poeira com diâmetro superior a 0,5 micrometros, o que reflete uma alta eficiência de remoção de partículas de poeira variando de 0,1 a 0,5 micrometros (CHEN et al., 2018).

A maioria das obras de gaseificação usam biomassa de alta densidade (por exemplo, aparas de madeira) para gerar syngas. Mesmo assim, existem oportunidades em utilizar recursos de biomassa de baixa densidade subutilizados para produzir energia e eletricidade com alta eficiência e configuração mínima. Utilizando uma câmara de combustão ciclônica integrada com um motor SI de $10 \mathrm{~kW}$ funcionando em $100 \%$, a eficiência global da geração de energia foi de $21,3 \%$ usando combustível syngas e $22,7 \%$ usando combustível gás natural a $5 \mathrm{~kW}$ (INDRAWAN et al., 2017).

A emissão de $\mathrm{CO}_{2}$ do syngas reduziu com o aumento da potência, até a potência máxima de $5 \mathrm{~kW}$.

Em todas as potências, as emissões de $\mathrm{CO}$ do syngas foram menores que a do gás natural.

As emissões de $\mathrm{NO}_{\mathrm{x}}$ geradas pelo syngas foram menores que as gás natural, com o menor valor em plena carga (5 $\mathrm{kW})$.

O efeito da adição de syngas na recirculação de gases de escape e condições de ar diluído é mais oportuna na recirculação do que a diluição do ar em termos de eficiência térmica, além do benefício da estabilidade de combustão.

As emissões de $\mathrm{NO}_{\mathrm{x}}$ são reduzidas com a diluição no sistema de recirculação, mas as emissões de monóxido de carbono são maiores no sistema de recirculação do que na diluição do ar (HAN et al., 2017).

As emissões de $\mathrm{HC}$ syngas foram menores do que aquelas que usam gás natural.

As emissões de $\mathrm{SO}_{2}$ do combustível syngas foram consistentemente inferiores às do gás natural.

A utilização de syngas no sistema de combustão pode alcançar alta eficiência térmica com base em propriedades termodinâmicas de mistura favoráveis. Pesquisas mostram que ao analisar a combustão do syngas este é aquele que tem o menor limite mínimo de falha de ignição entre gasolina, etanol e gás natural. Isto ocorre devido alta velocidade da chama laminar, difusividade e temperatura da chama adiabática, de acordo com a concentração de hidrogênio presente no syngas, apesar de os combustíveis gasosos não atingirem o mesmo nível de potência que os combustíveis líquidos (RAN et al., 2019).

$\mathrm{O}$ aumento da fração $\mathrm{H}_{2}$ no combustível syngas aumenta a permeação de oxigênio bem como a temperatura de combustão, melhorando significativamente a combustão (NEMITALLAH et al., 2017).

Além disso, ao aumentar a razão $\mathrm{H}_{2}$ no gás combustível syngas, o consumo específico de combustível pode ser reduzido. A faixa ótima de concentração de $\mathrm{H}_{2}$ no gás combustível syngas está entre $60 \%$ e $80 \%$, sendo que $75 \%$ é o valor ideal (XU et al., 2018)

$O$ hidrogênio ainda influencia significativamente na forma da chama, tempo de propagação e velocidade. Esta velocidade flutua à medida que a sobrepressão aumenta gradualmente. As ondas de pressão ainda desempenham um papel dominante na formação de chama. A interação entre a frente de chama e as ondas de pressão impactam na distorção da chama (YU et al., 2018).

A adição de hidrogênio a combustão de forma indireta, também melhora o desempenho da combustão e a emissão de poluentes. A temperatura das chamas do syngas aumenta com o incremento de hidrogênio na zona da chama. Em decorrência das baixas temperaturas de chama, o teor de $\mathrm{NO}_{\mathrm{X}}$ gerado na chama do syngas é menor que os da chama do gás natural. No entanto, os níveis de $\mathrm{NO}_{\mathrm{X}}$ aumentam rapidamente à medida que o hidrogênio é fornecido à chama e , também, a presença de $\mathrm{CO}_{2}$ nos combustíveis (até $8 \%$ em volume) eleva as emissões de $\mathrm{CO}_{2}$ (KARYEYEN; ILBAS, 2017).

A utilização de catalizadores básicos para captura de $\mathrm{CO}_{2}$ também aumentam a produção de syngas, uma vez que estes quando aplicados, eliminam os depósitos de carbono (VASCONCELOS et al., 2018).

Nas usinas tradicionais de carvão para syngas, a concentração de $\mathrm{CO}_{2}$ foi aumentada para aproximadamente 30 e $40 \%$ após os processos de gaseificação (FAN et al., 2018).

O consumo de cada tonelada de carvão gera $10,7 \mathrm{t}$ de $\mathrm{CO}_{2}$, este valor é de 3,3 vezes para o petróleo convencional. Além disso, o valor de água consumidos são de cerca de $33 \mathrm{t}$ por tonelada de carvão. Já o consumo de biomassa para produção de energia há redução nas emissões de $\mathrm{CO}_{2}$ em $98 \%$, apesar dos custos de investimentos serem desfavoráveis (YANG et al., 2018).

\section{CONCLUSÃO}

O crescimento da utilização de syngas tem demonstrado consonância com a necessidade de descobertas de novas fontes de energia. Ainda se utiliza uma grande quantidade de carvão para a produção do syngas tornando-o, em uma parcela de sua disponibilização para consumo, um combustível não renovável. A oportunidade de utilização, e que ainda acarreta em 
benefícios para o planeta, é a utilização de biomassa como matéria-prima, que são resíduos orgânicos dos vários processos produtivos no planeta. Além disso, os processos de cogeração de energia, captura de $\mathrm{CO}_{2}$ em valores acima de $98 \%$, produção de oxigênio, entre outros, fazem deste processo uma matriz energética importante na contribuição do desenvolvimento sustentável do planeta. Os resultados de eficiência energética e exergética suportam sua ampliação, mesmo que ainda hajam questões técnicas e governamentais a serem resolvidas.

\section{REFERÊNCIAS}

AL-ATTAB, K. A.; ZAINAL, Z. A. Micro gas turbine running on naturally aspirated syngas: An experimental investigation. Renewable Energy, v. 119, p. 210-216, 2018. Elsevier Ltd. Disponível

<https://doi.org/10.1016/j.renene.2017.12.008>. .

AlEMANY, J. M.; MOITRE, D.; MAGNAGO, F. Power System Reliability Considering Combined Cycle Plants. IEEE Latin America Transactions, v. 8, n. 5, p. 547-556, 2010. Disponível em: 〈https://doi.org/10.1109/TLA.2010.5623508>.

ASIMAKOPOULOS, K.; GAVALA, H. N.; SKIADAS, I. V. Reactor systems for syngas fermentation processes: A review. Chemical Engineering Journal, v. 348, n. March, p. 732-744, 2018. Elsevier. Disponível em: <https://doi.org/10.1016/j.cej.2018.05.003>. .

ASLANI, A.; MAZZUCA-SOBCZUK, T.; EIVAZI, S.; BEKHRAD, K. Analysis of bioenergy technologies development based on life cycle and adaptation trends. Renewable Energy, v. 127, p. 1076-1086, 2018. Elsevier Ltd. Disponível

<https://doi.org/10.1016/j.renene.2018.05.035>. .

CHEIN, R.-Y.; HSU, W.-H. Thermodynamic analysis of syngas production via tri-reforming of methane and carbon gasification using flue gas from coal-fired power plants. Journal of Cleaner Production, v. 200, p. 242-258, 2018. Elsevier Ltd. Disponível em: <https://doi.org/10.1016/j.jclepro.2018.07.228>. .

CHEN, Y. S.; HSIAU, S. S.; SHU, D. Y. System efficiency improvement of IGCC with syngas clean-up. Energy, v. 152, p. 75-83, 2018. Elsevier Ltd. Disponível em: <https://doi.org/10.1016/j.energy.2018.03.109>. .

COZZOLINO, R.; LOMBARDI, L.; TRIBIOLI, L. Use of biogas from biowaste in a solid oxide fuel cell stack: Application to an off-grid power plant. Renewable Energy, v. 111, p. 781-791, 2017. Elsevier Ltd. Disponível em: <http://dx.doi.org/10.1016/j.renene.2017.04.027>. .

DAMBROSIO, L.; FORTUNATO, B.; TORRESI, M.; MARIO CAMPOREALE, S.; FORNARELLI, F. Performance optimization of a gas-steam combined power plant partially fed with syngas derived from pomace. Energy Procedia, v. 126, p. 533-540, 2017. Elsevier B.V. Disponível em: <https://doi.org/10.1016/j.egypro.2017.08.265>. .

DESCAMPS, C.; BOUALlOU, C.; KANNICHE, M. Efficiency of an Integrated Gasification Combined Cycle (IGCC) power plant including CO2removal. Energy, v. 33, n. 6, p. 874-881, 2008. Disponível em: <https://doi.org/10.1016/j.energy.2007.07.013>. .

DINCA, C.; SLAVU, N.; CORMOŞ, C. C.; BADEA, A.
CO2capture from syngas generated by a biomass gasification power plant with chemical absorption process. Energy, v. 149, p. 925-936, 2018. Disponível em: <https://doi.org/10.1016/j.energy.2018.02.109>. .

FAN, J.; HONG, H.; JIN, H. Biomass and coal co-feed power and SNG polygeneration with chemical looping combustion to reduce carbon footprint for sustainable energy development: Process simulation and thermodynamic assessment. Renewable Energy, v. 125, p. 260-269, 2018. Elsevier Ltd. Disponível

<https://doi.org/10.1016/j.renene.2018.02.116>. .

FORMAN, C.; GOOTZ, M.; WOLFERSDORF, C.; MEYER, B. Coupling power generation with syngas-based chemical synthesis. Applied Energy, v. 198, p. 180-191, 2017. Elsevier Ltd. Disponível em: <http://dx.doi.org/10.1016/j.apenergy.2017.04.053>. .

GONZÁlEZ, W. A.; PÉREZ, J. F.; CHAPELA, S.; PORTEIRO, J. Numerical analysis of wood biomass packing factor in a fixed-bed gasification process. Renewable Energy, v. 121, n. $x, \quad$ p. 579-589, 2018. Disponível em: <https://doi.org/10.1016/j.renene.2018.01.057>. .

HAN, L.; DENG, G.; LI, Z.; LIU, P.; FAN, Y. Influences of syngas pretreatment on the performance and energy distribution in an IGCC power plant. Chemical Engineering Research and Design, v. 131, p. 117-126, 2018. Institution of Chemical Engineers. Disponível em: <https://doi.org/10.1016/j.cherd.2017.12.007>. .

HAN, T.; LAVOIE, G.; WOOLDRIDGE, M.; BOEHMAN, A. Effect of Syngas $\left(\mathrm{H}_{2} / \mathrm{CO}\right)$ on SI Engine Knock under Boosted EGR and Lean Conditions. SAE International Journal of Engines, v. 10, n. 3, p. 2017-01-0670, 2017. Disponível em: <http://doi.org/10.4271/2017-01-0670 >. .

INDRAWAN, N.; THAPA, S.; BHOI, P. R.; HUHNKE, R. L.; KUMAR, A. Engine power generation and emission performance of syngas generated from low-density biomass. Energy Conversion and Management, v. 148, p. 593-603, 2017. Elsevier Ltd. Disponível em: <http://dx.doi.org/10.1016/j.enconman.2017.05.066>. .

KARYEYEN, S.; ILBAS, M. Turbulent diffusion flames of coal derived-hydrogen supplied low calorific value syngas mixtures in a new type of burner: An experimentalï $\iota^{1 / 2}$ study. International Journal of Hydrogen Energy, v. 42, n. 4, p. 2411-2423, 2017. Elsevier Ltd. Disponível em: <http://dx.doi.org/10.1016/j.ijhydene.2016.09.063>.

KAUSHAL, P.; TYAGI, R. Advanced simulation of biomass gasification in a fluidized bed reactor using ASPEN PLUS. Renewable Energy, v. 101, p. 629-636, 2017. Elsevier Ltd. Disponível <http://dx.doi.org/10.1016/j.renene.2016.09.011>. .

KOBAYASHI, M.; AKIHO, H. Dry syngas purification process for coal gas produced in oxy-fuel type integrated gasification combined cycle power generation with carbon dioxide capturing feature. Journal of Environmental Management, v. 203, p. 925-936, 2017. Elsevier Ltd. Disponível <https://doi.org/10.1016/j.jenvman.2017.05.067>. .

NEMITALLAH, M. A.; HABIB, M. A.; SALAUDEEN, S. A.; MANSIR, I. Hydrogen production, oxygen separation and syngas oxy-combustion inside a water splitting membrane 
reactor. Renewable Energy, v. 113, p. 221-234, 2017. Elsevier Ltd. Disponível em: <http://dx.doi.org/10.1016/j.renene.2017.05.086>. .

OGORURE, O. J.; OKO, C. O. C.; DIEMUODEKE, E. O.; OWEBOR, K. Energy, exergy, environmental and economic analysis of an agricultural waste-to-energy integrated multigeneration thermal power plant. Energy Conversion and Management, v. 171, n. March, p. 222-240, 2018. Elsevier. Disponível

<https://doi.org/10.1016/j.enconman.2018.05.093>. .

OH, G.; RA, H. W.; YOON, S. M.; et al. Syngas production through gasification of coal water mixture and power generation on dual-fuel diesel engine. Journal of the Energy Institute, p. 1-10, 2018. Elsevier Ltd. Disponível em: <https://doi.org/10.1016/j.joei.2018.01.009>.

PALA, L. P. R.; WANG, Q.; KOLB, G.; HESSEL, V. Steam gasification of biomass with subsequent syngas adjustment using shift reaction for syngas production: An Aspen Plus model. Renewable Energy, v. 101, p. 484-492, 2017. Elsevier Ltd. Disponível <http://dx.doi.org/10.1016/j.renene.2016.08.069>.

PEDROSO, D. T.; MACHIN, E. B.; PROENZA PÉREZ, N.; BRAGA, L. B.; SILVEIRA, J. L. Technical assessment of the Biomass Integrated Gasification/Gas Turbine Combined Cycle (BIG/GTCC) incorporation in the sugarcane industry. Renewable Energy, v. 114, p. 464-479, 2017. Disponível em: <https://doi.org/10.1016/j.renene.2017.07.038>. .

PERNA, A.; MINUTILLO, M.; JANNELLI, E.; et al. Performance assessment of a hybrid SOFC/MGT cogeneration power plant fed by syngas from a biomass down-draft gasifier. Applied Energy, , n. January, p. 1-13, 2017. Elsevier. Disponível

<http://dx.doi.org/10.1016/j.apenergy.2017.08.077>. .

PRAKASH, M.; SARKAR, A.; SARKAR, J.; MONDAL, S. S.; CHAKRABORTY, J. P. Proposal and design of a new biomass based syngas production system integrated with combined heat and power generation. Energy, v. 133, p. 986997, 2017. Elsevier Ltd. Disponível em: <http://dx.doi.org/10.1016/j.energy.2017.05.161>.

RAN, Z; HARIHARAN, D.; LAWLER, B.; MAMALIS, S. Experimental study of lean spark ignition combustion using gasoline, ethanol, natural gas, and syngas. Fuel, v. 235, n. May 2018, p. 530-537, 2019. Elsevier. Disponível em: <https://doi.org/10.1016/j.fuel.2018.08.054>. .

RYZHKOV, A.; BOGATOVA, T.; GORDEEV, S. Technological solutions for an advanced IGCC plant. Fuel, v. 214, n. 14, p. 63-72, 2018. Elsevier. Disponível em: <https://doi.org/10.1016/j.fuel.2017.10.099>. .

SANSANIWAL, S. K.; ROSEN, M. A.; TYAGI, S. K. Global challenges in the sustainable development of biomass gasification: An overview. Renewable and Sustainable Energy Reviews, v. 80, n. March 2016, p. 23-43, 2017. Elsevier Ltd. Disponível em: <http://dx.doi.org/10.1016/j.rser.2017.05.215>. .

SANTOS, V. E. S.; REGO, E. E.; SANTOS, E. M.; RIBEIRO, C. O. Shale Gas and the Replacement of Coal-Fired Power Plants. IEEE Latin America Transactions, v. 14, n. 8, p. 3721-3730, 2016. Disponível em: <https://doi.org/10.1109/TLA.2016.7786356>. .
SCARLAT, N.; DALLEMAND, J. F.; FAHL, F. Biogas: Developments and perspectives in Europe. Renewable Energy, v. 129, p. 457-472, 2018. Elsevier Ltd. Disponível em: <https://doi.org/10.1016/j.renene.2018.03.006>. .

SHEIKH, H. M.; ULLAH, A.; HONG, K.; ZAMAN, M. Thermo-economic analysis of integrated gasification combined cycle (IGCC) power plant with carbon capture. Chemical Engineering and Processing - Process Intensification, v. 128, n. January, p. 53-62, 2018. Elsevier. Disponível em: <https://doi.org/10.1016/j.cep.2018.04.007>. .

SOLARTE-TORO, J. C.; CHACÓN-PÉREZ, Y.; CARDONA-ALZATE, C. A. Evaluation of biogas and syngas as energy vectors for heat and power generation using lignocellulosic biomass as raw material. Electronic Journal of Biotechnology, v. 33, p. 52-62, 2018. Elsevier España, S.L.U. Disponível em: <https://doi.org/10.1016/j.ejbt.2018.03.005>. .

VASCONCELOS, B. R. DE; PHAM MINH, D.; LYCZKO, $\mathrm{N}$.; et al. Upgrading greenhouse gases (methane and carbon dioxide) into syngas using nickel-based catalysts. Fuel, v. 226, n. March, p. 195-203, 2018. Elsevier. Disponível em: <https://doi.org/10.1016/j.fuel.2018.04.017>. .

WANG, J.; MAO, T.; SUI, J.; JIN, H. Modeling and performance analysis of CCHP (combined cooling, heating and power) system based on co-firing of natural gas and biomass gasification gas. Energy, v. 93, p. 801-815, 2015. Elsevier Ltd. Disponível em:

<http://dx.doi.org/10.1016/j.energy.2015.09.091>. .

XU, Z.; JIA, M.; LI, Y.; et al. Computational optimization of fuel supply, syngas composition, and intake conditions for a syngas/diesel RCCI engine. Fuel, v. 234, n. April, p. 120-134, 2018. Elsevier. Disponível em: <https://doi.org/10.1016/j.fuel.2018.07.003>. .

YANG, S.; YANG, Y.; KANKALA, R. K.; LI, B. Sustainability assessment of synfuels from biomass or coal: An insight on the economic and ecological burdens. Renewable Energy, v. 118, p. 870-878, 2018. Elsevier Ltd. Disponível em: <https://doi.org/10.1016/j.renene.2017.11.073>. .

YAO, Z.; YOU, S.; GE, T.; WANG, C. H. Biomass gasification for syngas and biochar co-production: Energy application and economic evaluation. Applied Energy, v. 209, n. October 2017, p. 43-55, 2018. Disponível em: <https://doi.org/10.1016/j.apenergy.2017.10.077>. .

YU, M.; YANG, X.; ZHENG, K.; ZHENG, L.; WEN, X. Experimental study of premixed syngas/air flame deflagration in a closed duct. International Journal of Hydrogen Energy, v. 43, n. 29, p. 13676-13686, 2018. Elsevier Ltd. Disponível em: <https://doi.org/10.1016/j.ijhydene.2018.05.103>.

ZAINI, I. N.; NURDIAWATI, A.; AZIZ, M. Cogeneration of power and H2by steam gasification and syngas chemical looping of macroalgae. Applied Energy, v. 207, p. 134-145, 2017. Elsevier Ltd. Disponível em: <https://doi.org/10.1016/j.apenergy.2017.06.071>. .

\section{COPYRIGHT}

Direitos autorais: Os autores são os únicos responsáveis pelo material incluído no artigo. 


\title{
Revista SODEBRAS - Volume 14 $\mathrm{N}^{\circ} 157$ - JANEIRO/ 2019
}

\section{INFLUÊNCIA DA RELAÇÃO DE PRESSÃO E FRAÇÃO DE AR EXTRAÍDA DO COMPRESSOR NO ARREFECIMENTO DAS PÁS DE TURBINAS A GÁS}

\author{
INFLUENCE OF THE PRESSURE RATIO AND AIR FRACTION EXTRACTED \\ FROM THE COMPRESSOR ON GAS TURBINE BLADES COOLING
}

\author{
CRYSTIARA PAULA SANTOS DA SILVA VENÂNCIO ${ }^{1}$, LARISSA RODRIGUES MARCONI²; \\ FILIPE ARTHUR FIRMINO MONHOL ${ }^{3}$ \\ 1; 2; 3 - INSTITUTO FEDERAL DO ESPÍRITO SANTO \\ crystiarapaula@gmail.com,larissa_rodrigues12@hotmail.com, filipe.monhol@ifes.edu.br
}

\begin{abstract}
Resumo - Turbinas a gás são muito utilizadas na propulsão de aeronaves e conversão de energia. O desempenho global de tal equipamento pode ser melhorado aumentando-se o limite térmico permissível nas pás de seus rotores, através de tecnologias de arrefecimento interno. Assim, esse estudo analisa a influência das características de tal arrefecimento no comportamento térmico das pás. Uma modelagem termodinâmica do processo, e a utilização do método das diferenças finitas, possibilitou avaliar como a relação de pressão e a fração de ar desviada do compressor afetam as temperaturas e o fluxo de calor removido das pás. Observou-se que um aumento da fração de ar desviada de 10 para $20 \%$ diminui a temperatura da pá da turbina em até 130K. Além disso, maiores valores de relação de pressão, embora aumentem o rendimento do equipamento, resultam em maiores solicitações térmicas da pá e consequente menor vida útil.
\end{abstract}

Palavras-chave: Turbina a Gás. Gradiente Térmico. Pá de Turbina.

\begin{abstract}
Gas turbines are used in aircraft propulsion and power generation. The overall performance of this equipment can be improved by increasing the allowable thermal limit on the rotor blades through internal cooling technologies. Thus, this study analyzes the influence of the cooling characteristics on the thermal behavior of the blades. A thermodynamic modeling of the process and the finite difference method, made it possible to evaluate how the pressure ratio and the air fraction deviated from the compressor affect the temperature and heat flow of the blades. It has been observed that an increase in air fraction of 10 to $20 \%$ decreases turbine blade temperature by up to $130 \mathrm{~K}$. In addition, higher pressure ratios, while increasing equipment efficiency, result in higher blade thermal loads and consequent shorter tool life.
\end{abstract}

Keywords: Gas Turbine. Thermal Gradient. Turbine Rotor Blades.

\section{INTRODUÇÃO}

Turbinas a gás são máquinas amplamente utilizadas em aplicações aeronáuticas e termelétricas, produzindo trabalho útil a partir de uma fonte térmica de energia. Os grandes desenvolvimentos na área das turbinas a gás foram, basicamente, na melhora de seus equipamentos e no aumento da temperatura máxima do ciclo a fim de se obter maiores eficiências (SALPINGIDOU et al., 2018). Tipicamente, as temperaturas do gás quente produzido na câmara de combustão e direcionado às pás da turbina de expansão, são da ordem de $2000 \mathrm{~K}$, sujeitando-as a condições que podem ultrapassar os limites térmicos dos materiais (SCIUBBA, 2015). Apesar das pás das turbinas a gás serem revestidas por uma barreira térmica (RBT), composta por materiais cerâmicos para resistirem a altas temperaturas, a elevação da carga térmica sobre os componentes faz com que a vida útil das pás da turbina a gás possa ser reduzida significantemente (SAHITH et al., 2018; ASL e RAMEZANLOU, 2019). Assim, há a necessidade de tecnologias de resfriamento adequadas para reduzir as solicitações termomecânicas nos materiais de seus componentes.

Entre os tipos de resfriamento existentes, o que será analisado neste artigo é o resfriamento convectivo interno. Neste modelo as pás são resfriadas por canais internos por onde flui o ar de arrefecimento em diferentes arranjos e configurações diminuindo a temperatura das paredes dos canais por convecção forçada (XU et al., 2015; SUNDBERG, 2006). O ar que escoa por esses canais é proveniente do desvio de uma parcela de ar na saída do compressor. Este ar extraído é injetado dentro e ao redor das palhetas, misturando-se com a corrente principal do gás (proveniente da câmara de combustão), mantendo-se, assim, a temperatura do material das palhetas na temperatura desejável (WANG, 2015).

Estudos na área de resfriamento interno das pás têm sido realizados, em sua maioria utilizando simulação computacional, visando maneiras de se ter uma maior dissipação do calor ao qual a pá está sujeita. Alguns destes se concentram em desenvolver novas geometrias e distribuições de escoamento para os canais, como é o caso dos trabalhos de Zhou et al. (2018) e Wang (2015). Já outros, buscam aperfeiçoar a transferência de calor nos canais de resfriamento já existentes, através de mudanças nas características e nos parâmetros do escoamento, como o trabalho de Li et al. (2018) e Fan et al. (2018).

Conforme será observado no presente trabalho, dentre tais parâmetros que influenciam o gradiente térmico e a intensidade de calor dissipado nas pás, está a fração do ar de resfriamento que é extraída do compressor para os canais internos. De acordo com Salpingidou et al. (2018), sabe-se que a medida em que a temperatura operacional da turbina cresce a fim de se obter maior potência, o fluxo de massa exigido para resfriamento da turbina também deve ser maior, o que geraria uma penalidade de eficiência devido ao ar extraído do compressor. Por isso, é necessário uma análise 
que indique se tal penalidade na eficiência do equipamento, por se aumentar a extração de ar em determinada quantidade, será vantajosa do ponto de vista do gradiente térmico no material. Caso a solicitação no material diminua e os fluxos térmicos sejam menores, mesmo o equipamento trabalhando em menor eficiência há a possibilidade de se aumentar a vida útil do equipamento como um todo, valendo então uma análise mais detalhada.

Outro parâmetro que influencia o comportamento térmico das pás de uma turbina é a razão de pressão do compressor, ou seja, o aumento de pressão imposto pelo mesmo. Segundo Meroni et al. (2018), em turbinas modernas de alta eficiência de ciclo e densidade de potência, frequentemente são adotados altos valores dessa razão (pelo menos acima de 6). No entanto, altos valores de pressão, e temperatura associada, tendem a aumentar a carga térmica nas pás da turbina (DU et. al, 2019). Assim, os valores utilizados de razão de pressão devem ser restringidos pelos limites térmicos do material das pás. Embora valores elevados se justifiquem devido a obtenção de alto desempenho energético, deve-se, contudo, analisar as solicitações internas no material para essas faixas de trabalho a fim de saber se o mesmo terá uma vida útil menor, dadas às elevadas cargas térmicas.

Desse modo, dada a demanda científica no Brasil em relação aos parâmetros que influenciam o resfriamento convectivo interno nas pás de turbinas a gás, uma análise que busque aumentar a eficiência do ciclo, contudo respeitando as barreiras térmicas do material, pode ser de grande importância para o sucesso no desempenho operacional das turbinas a gás. Portanto, neste artigo será analisada, a partir de modelagem computacional, a influência da razão de pressão e fração de ar de resfriamento desviada do compressor no comportamento térmico das pás de uma turbina a gás.

\section{METODOLOGIA}

A fim de obter os parâmetros de desempenho da turbina analisada, realizou-se, em primazia, a modelagem termodinâmica do problema envolvendo as reações químicas na câmara de combustão e balanços de energia nos equipamentos. Um código computacional na linguagem Visual Basic for Applications (VBA) do Microsoft Office Excel ${ }^{\circledR}$ foi utilizado para efetivação dos cálculos. A modelagem foi realizada com base nas seguintes hipóteses simplificadoras: Condições de estado estacionário em todos os elementos do ciclo (compressor de ar, câmara de combustão e turbina); Desempenho adiabático do compressor de ar, câmara de combustão e turbina a gás; Os efeitos cinéticos e potenciais no compressor, na câmara de combustão e na turbina são desprezíveis; Composição fixa de ar e dos produtos de combustão durante os processos de compressão e expansão, respectivamente, sendo ambos compostos de $\mathrm{O}_{2}, \mathrm{~N}_{2}, \mathrm{CO}_{2}$ e $\mathrm{H}_{2} \mathrm{O}$ em diferentes proporções para cada um; Gás natural modelado como metano $\left(\mathrm{CH}_{4}\right)$ puro (MEMOM, 2013); A pressão dos gases de combustão na entrada da turbina é igual à pressão de ar na saída do compressor; As temperaturas e estados em cada região interna do equipamento devem ser obtidos para calcular os parâmetros de transferência de calor nas pás, e também averiguar a potência e desempenho do mesmo.

As equações necessárias para tais cálculos são apresentadas a seguir. Da Eq. (1), para dados valores de temperatura de entrada $\left(T_{1}\right)$ e razão de pressão no compressor $\left(\mathbf{r}_{\mathbf{p}}\right)$, pode se obter a temperatura do ar na saída do compressor caso o mesmo fosse ideal, ou isentrópico $\left(\mathrm{T}_{2 \mathrm{~s}}\right)$, ou seja, sob uma variação entrópica $(\Delta \overline{\mathrm{s}})$ nula. Pode-se então, aplicando a Eq. (2), determinar a variação entálpica $(\Delta \overline{\mathrm{h}})$ para os casos real e isentrópico, e utilizando a eficiência isentrópica do compressor $\left(\eta_{C}^{I S O}\right)$ na Eq. (3), obter o valor da temperatura real de saída do compressor $\left(\mathrm{T}_{2}\right)$. É importante definir o estado do ar na saída do compressor, dado que uma fração desviada desse ar será utilizada no arrefecimento dos canais internos das pás da turbina. A composição utilizada para o ar (números de moles $n_{i}$ de cada substância), bem como os coeficientes $\overline{\mathrm{A}}_{i}, \overline{\mathrm{B}}_{\mathrm{i}}, \overline{\mathrm{C}}_{\mathrm{i}}, \overline{\mathrm{D}}_{\mathrm{i}}$ e $\overline{\mathrm{R}}_{\mathrm{i}}$ de cada componente do ar, são obtidos a partir de Moran e Shapiro (2013).

$$
\begin{aligned}
& \Delta \overline{\mathrm{s}}_{1-2 \mathrm{~s}}=\sum \mathrm{n}_{\mathrm{i}}\left[\int_{\mathrm{T}_{1}}^{\mathrm{T}_{2 \mathrm{~s}}}\left(\overline{\mathrm{A}}_{\mathrm{i}}+\overline{\mathrm{B}}_{\mathrm{i}} \mathrm{T}+\overline{\mathrm{C}}_{\mathrm{i}} \mathrm{T}^{2}+\overline{\mathrm{D}}_{\mathrm{i}} \mathrm{T}^{3}\right) \mathrm{dT}-\overline{\mathrm{R}}_{\mathrm{i}} \ln \left(\mathbf{r}_{\mathbf{p}}\right)\right] \\
& \Delta \overline{\mathrm{h}}_{1-2}=\sum \mathrm{n}_{\mathrm{i}}\left[\int_{\mathrm{T}_{1}}^{\mathrm{T}_{2}}\left(\overline{\mathrm{A}}_{\mathrm{i}}+\overline{\mathrm{B}}_{\mathrm{i}} \mathrm{T}+\overline{\mathrm{C}}_{\mathrm{i}} \mathrm{T}^{2}+\overline{\mathrm{D}}_{\mathrm{i}} \mathrm{T}^{3}\right) \mathrm{dT}\right] \\
& \Delta \overline{\mathrm{h}}_{1-2}=\frac{\Delta \overline{\mathrm{h}}_{1-2 \mathrm{~s}}}{\eta_{\mathrm{C}}^{\mathrm{ISO}}}
\end{aligned}
$$

A modelagem realizada considera reações químicas de combustão completa no interior do equipamento, onde as perdas de energia na câmara são contabilizadas com base em uma dada eficiência da câmara de combustão $\left(\eta_{\mathrm{CC}}\right)$, conforme se utiliza comumente nos modelos da literatura (TORRES, 2018; MEMON et al., 2013; AHMADI, et al., 2013; ERSAYIN e OZGENER, 2015).

Por meio da Eq. (4), onde o lado direito representa a energia total dos reagentes e o lado esquerdo a dos produtos, obtém-se a temperatura de entrada na turbina, que incide externamente em suas pás $\left(\mathrm{T}_{3}\right)$. Os valores de entalpia de formação padrão $\left(\overline{\mathrm{h}}_{\mathrm{f} \text { i }}^{0}\right)$ na temperatura de referencia $\left(\mathrm{T}_{0}\right)$ e os coeficientes $\overline{\mathrm{A}}_{\mathrm{i}}, \overline{\mathrm{B}}_{\mathrm{i}}, \overline{\mathrm{C}}_{\mathrm{i}}, \overline{\mathrm{D}}_{\mathrm{i}}$ de cada um dos produtos e reagentes também são obtidos de Moran e Shapiro (2013). Já os números de moles $\left(\mathrm{n}_{\mathrm{i}}\right)$ de cada substância envolvida são obtidos a partir do balanceamento da reação química de combustão completa do combustível, afim de encontrar a composição do gás que incidirá na superfície externa das pás da turbina.

$$
\begin{aligned}
& \eta_{\mathrm{CC}} \cdot \sum_{\text {Prod }} \mathrm{n}_{\mathrm{i}}\left(\overline{\mathrm{h}}_{\mathrm{f} \mathrm{i}}^{0}+\int_{\mathrm{T}_{0}}^{\mathrm{T}_{3}}\left(\overline{\mathrm{A}}_{\mathrm{i}}+\overline{\mathrm{B}}_{\mathrm{i}} \mathrm{T}+\overline{\mathrm{C}}_{\mathrm{i}} \mathrm{T}^{2}+\overline{\mathrm{D}}_{\mathrm{i}} \mathrm{T}^{3}\right) \mathrm{dT}\right)_{\text {Prod }} \\
& =\sum_{\text {Reag }} \mathrm{n}_{\mathrm{i}}\left(\overline{\mathrm{h}}_{\mathrm{f} i}^{0}+\int_{\mathrm{T}_{0}}^{\mathrm{T}_{2}}\left(\overline{\mathrm{A}}_{\mathrm{i}}+\overline{\mathrm{B}}_{\mathrm{i}} \mathrm{T}+\overline{\mathrm{C}}_{\mathrm{i}} \mathrm{T}^{2}+\overline{\mathrm{D}}_{\mathrm{i}} \mathrm{T}^{3}\right) \mathrm{dT}\right)_{\text {Reag }}
\end{aligned}
$$

O cálculo da temperatura na saída da turbina $\left(\mathrm{T}_{4}\right)$ é feito de forma análoga ao de $\mathrm{T}_{2}$, usando, porém, a eficiência isentrópica e a razão de pressão da turbina, bem como a composição do gás.

A fim de avaliar o desempenho global do equipamento, a potência líquida ( $\dot{\mathrm{W}}_{\text {líq }}$ ) pode ser obtida de acordo com a Eq. (5), onde os termos variacionais entálpicos são obtidos aplicando a Eq. (2) aos respectivos estados em cada região do equipamento. Além disso, uma vez conhecida a vazão de combustível $\left(\dot{\mathrm{m}}_{\mathrm{comb}}\right)$, pode-se obter a vazão de ar que passa pelo compressor, bem como a do gás que passa pelas pás da turbina, a partir da relação ar-combustível $(A / C)$ da reação de combustão completa. 


$$
\dot{\mathrm{W}}_{\text {liq }}=\dot{\mathrm{m}}_{\text {comb }}\left[(1+A / C) \Delta \overline{\mathrm{h}}_{3-4}-(A / C) \Delta \overline{\mathrm{h}}_{1-2}\right]
$$

Foram utilizados os dados operacionais da turbina NASA Energy Efficient Engine GE-E3 (WENTONG et al., 2018; SABOOHI et al. 2019; DAVIS e STEARNS, 1985; HALILA et al., 1982), conforme indicados na Tabela 1. Tal turbina há bastante tempo tem servido de base para cálculos termodinâmicos na área, dada a sua boa eficiência operacional.

Tabela 1- Parâmetros operacionais da turbina a gás GE-E3

\begin{tabular}{l|c|c}
\hline \multicolumn{1}{c|}{ Parâmetro } & Símbolo & Valor \\
\hline Consumo de combustível $\left(\mathrm{CH}_{4}\right)$ & $\dot{m}_{\text {comb }}$ & $3,11 \mathrm{~kg} / \mathrm{s}$ \\
\hline Pressão do ar ambiente & $P_{a r}$ & $0,6 \mathrm{bar}$ \\
\hline Excesso de ar na turbina & $\alpha$ & $100 \%$ \\
\hline $\begin{array}{l}\text { Eficiência isentrópica do } \\
\text { compressor }\end{array}$ & $\eta_{C}^{I S O}$ & $86,1 \%$ \\
\hline $\begin{array}{l}\text { Eficiência da câmara de } \\
\text { combustão }\end{array}$ & $\eta_{C C}$ & $99 \%$ \\
\hline Eficiência isentrópica da turbina & $\eta_{T G}^{I S O}$ & $92,6 \%$ \\
\hline $\begin{array}{l}\text { Relação de pressão do } \\
\text { compressor }\end{array}$ & $\mathbf{r}_{\mathbf{p}}$ & 22,4 \\
\hline Razão de expansão da turbina & $r_{t g}$ & 16,675 \\
\hline $\begin{array}{l}\text { Efetividade adiabática média do } \\
\text { filme de resfriamento externo }\end{array}$ & $\eta$ & 0,4 \\
\hline $\begin{array}{l}\text { Vazão mássica de ar desviado do } \\
\text { compressor }\end{array}$ & $\mathbf{m}$ & $18,87 \%$ \\
\hline $\begin{array}{l}\text { Vazão de ar desviada que vai } \\
\text { resfriar as pás do 1 }{ }^{\circ} \text { estágio da } \\
\text { turbina. }\end{array}$ & $\mathrm{m}_{1}$ & $3,3 \%$ \\
\hline
\end{tabular}

O modelo da pá da turbina analisado neste trabalho é o GE-E3 stage-1 HPT (DU et al., 2019; WENTONG et al., 2018), um modelo de alto padrão de tecnologia de arrefecimento, usado nas turbinas de alto rendimento. $\mathrm{O}$ rotor do $1^{\circ}$ estágio da turbina possui 76 dessas pás, cada uma delas possuindo 6 canais internos. A condutividade térmica do material da pá da turbina é de $\mathrm{k}_{\mathrm{b}}=17,296 \mathrm{~W} / \mathrm{m} . \mathrm{K}$ e da camada RBT (com espessura de 0,254 mm) de $k_{a}=1,73$ W/m.K.

Para obtenção dos gradientes térmicos e dados de transferência de calor nas pás da turbina foi utilizado o método numérico das diferenças finitas por balanços de energia em vários pontos da pá, conforme apresentado por Incropera et al. (2007). O meio de interesse foi subdividido em pequenas regiões de simetria, onde se construiu a malha de nós a serem analisados, conforme indicada na Fig. 1. Como a pá e os canais possuem geometria complexa, a modelagem foi realizada com base numa geometria retangular 2-D, não sendo consideradas assim as variações de angulação da geometria, conforme se observa em uma pá convencional de turbina (FRĄCKOWIAK et al. 2019; ASL e RAMEZANLOU, 2019). Modelos como este podem apresentar discordâncias em comparação com o caso real, gerando erros da ordem de $15 \%$, segundo Incropera et al. (2007). Entretanto, apesar dessas possíveis disparidades, o método é viável para os casos em que se realiza uma adaptação da geometria mantendo a mesma área superficial e as mesmas condições internas presentes no contorno da pá de geometria complexa, conforme se observa no trabalho de Zeng et al. (2018).

Obtidas as temperaturas em cada nó, pôde-se calcular o calor removido pelo fluido de resfriamento por unidade de comprimento da pá ( $\left.\boldsymbol{q}^{\prime}\right)$ aplicando a Lei do Resfriamento de Newton aos nós em contato com o fluido.

Figura 1- Esquema 2-D da pá da turbina e a rede nodal utilizada

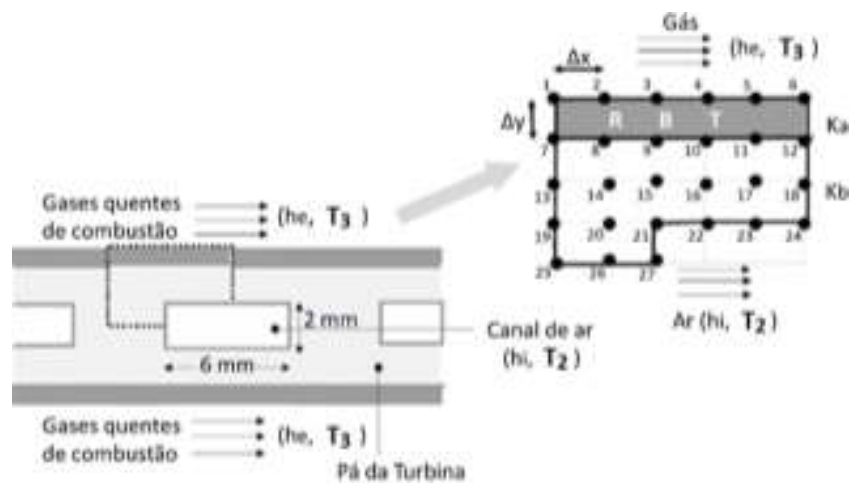

Fonte: Autores, 2018.

Para o coeficiente de transferência de calor por convecção do escoamento de ar do canal $\left(\mathrm{h}_{\mathrm{i}}\right)$, utilizou-se a equação de Sieder e Tate, considerando regime permanente e trocas por radiação desprezíveis (INCROPERA et al., 2007), conforme Eq. (6).

$$
\mathrm{h}_{\mathrm{i}}=\frac{\mathrm{k}}{\mathrm{D}} 0,027\left(\frac{4 \dot{\mathrm{m}}}{\pi \mathrm{D} \mu}\right)^{4 / 5} \mathrm{P}_{\mathrm{r}}^{1 / 3}\left(\frac{\mu}{\mu_{\mathrm{s}}}\right)^{0,14}
$$

Onde ṁ é a vazão de ar em cada um dos canais, D é o diâmetro do canal, $\mathrm{k}$ é a condutividade térmica do ar, Pr é o número de Prandt do ar, e $\mu / \mu_{\mathrm{s}}$ a razão de viscosidades do ar no centro do escoamento interno e na superfície da parede. As propriedades para esta equação são avaliadas na temperatura de filme, modeladas como sendo a média entre a temperatura da pá e a temperatura do ar de resfriamento desviado do compressor $\left(\mathrm{T}_{2}\right)$.

Para os escoamentos dos gases quentes provenientes da combustão utilizou-se o modelo de placa plana de comprimento L (BUNKER, 2006), conforme Eq. (7).

$$
\mathrm{h}_{\mathrm{e}}=0,0296 \mathrm{R}_{\mathrm{ex}}{ }^{4 / 5} \mathrm{P}_{\mathrm{r}}{ }^{1 / 3} \frac{\mathrm{k}}{\mathrm{L}}
$$

Sendo $R_{e x}$ o número de Reynolds do escoamento externo e as propriedades avaliadas na temperatura adiabática de filme $\left(\mathrm{T}_{\mathrm{adiab}}\right)$, que é a temperatura do gás que chega ao revestimento cerâmico RBT. Essa temperatura pode ser expressa como indicado na Eq. (8), onde a efetividade adiabática média do filme de resfriamento externo (n) adotada é de 0,4 (BUNKER 2006).

$$
\mathrm{T}_{\text {adiab }}=\mathrm{T}_{3}-\mathrm{\eta}\left(\mathrm{T}_{3}-\mathrm{T}_{2}\right)
$$

Dessa forma, no presente modelo, ao se alterar a vazão de ar desviada do compressor (m) para resfriamento das pás, a vazão interna nos canais é alterada, mudando também os parâmetros da convecção e de funcionamento do equipamento, influenciando assim o gradiente térmico da pá. Já se variando a relação de pressão do compressor $\left(\mathbf{r}_{\mathbf{p}}\right)$, alteram-se as temperaturas, pressões e características convectivas do ar de resfriamento que vem do compressor, bem como os parâmetros de funcionamento do equipamento, também influenciando o gradiente térmico da pá. O modelo termodinâmico foi ainda previamente validado utilizando 
diferentes dados operacionais disponíveis na literatura (MEMON et al., 2018; SANJAY, 2018; TORRES, 2018; AHMADI, 2013)) e comparando os resultados de temperatura obtidos.

Para as análises do presente trabalho, adotou-se uma faixa de variação da fração de ar desviada do compressor para resfriamento das pás da turbina, entre $10 \%$ a $20 \%$, conforme dados típicos de turbinas reais (SANJAY, 2018; COHEN et al., 1996), mantendo a relação de pressão do compressor em 22,4 , conforme Tab. 1. Para a razão de pressão foi avaliada uma faixa de 12 a 24, de acordo com dados típicos indicados por Torres (2018), mantendo a vazão de ar desviada do compressor indicada na Tab. 1.

\section{RESULTADOS}

A curva $m(\%)$ da Fig. 2 mostra a relação da temperatura média da pá para diferentes frações de vazão mássica desviada do compressor. Aumentando-se a vazão desviada de $10 \%$ para $20 \%$ obtem-se uma diminuição da temperatura média da pá, de cerca de $128 \mathrm{~K}$, o que é de grande valia, pois medidas para tal feito são almejadas e tornam-se de grande interesse na área de turbinas a gás.

É bem difundido ainda, que para se aumentar a eficiência do equipamento deve-se aumentar a temperatura de entrada da turbina (SALPINGIDOU et al., 2018; SCIUBBA, 2015). E quanto maior está temperatura maior será a potência útil fornecida pela turbina a gás. No entanto, seu limite é determinado pela temperatura máxima que o material da turbina pode suportar. Na curva $m(\%)$ da Fig.3, se pode ter uma indicação da maior temperatura em que a pá da turbina estará submetida. Observam-se em ambas as figuras que a temperatura máxima, assim como a temperatura média são diminuídas com uso da tecnologia de resfriamento, fazendo com o que a vida útil da pá seja prolongada.

De acordo com Bunker (2006), a tecnologia de resfriamento possui quatro elementos principais: resfriamento convectivo interno, filme de superfície de resfriamento externo, seleção de materiais e design termodinâmico. Utilizando o resfriamento convectivo interno, pôde-se obter o arrefecimento nas pás da turbina, possibilitando o aumento da eficiência do equipamento, por propiciar que a temperatura na entrada da turbina seja maior sem elevar de mais a temperatura do material da pá. Além disso, pode-se ainda optar pelo uso de materiais de menor custo. Segundo Sahith (2018), pode-se incluir ate mesmo, o uso de uma liga diferente, com maior condutividade térmica.

Nas curvas de $r_{p}$ da Fig. 2 e Fig. 3, observou-se que a temperatura máxima local da pá, bem como a sua temperatura média tendem a aumentar na medida em que se utilizam maiores valores de relação de pressão. Portanto, isso gera um ponto de cautela para os projetistas de turbinas a gás, pois já é bem difundido que para se obter uma boa eficiência termodinâmica do equipamento, em ciclo aberto, é essencial um alto valor para a razão de pressão do compressor (MERONI et al., 2018; COHEN et al., 1996). Contudo, os altos valores de temperatura para maiores relações de pressão podem gerar alguns problemas técnicos de escolha de matérias que suportem tais solicitações térmicas. Sciubba (2015) e Du et al. (2019) destacam que tanto as razões de pressão, quanto a temperatura na saída da câmara de combustão, são limitadas pelos limites do material. Estes limites são os limites metalúrgicos do material das lâminas das turbinas, especificamente a tensão da raiz da lâmina, o ponto de fusão do material e a máxima deformação por fluência que elas conseguem suportar. Além de distorcer as dimensões físicas e, assim reduzir, o desempenho da turbomáquina, as tensões de fluência induzidas acentuam as tensões de operação centrífuga e levam a falha prematura do material. Portanto o aumento da razão de pressão aumenta a eficiência termodinâmica do ciclo, mas o aumento exacerbado comprometerá a integridade metalúrgica das pás, fazendo-se necessário escolher com cautela a razão de pressão na qual o equipamento estará submetido.

Figura 2 - Efeito da fração de ar desviada do compressor (m) e da razão de pressão $\left(\mathbf{r}_{\mathbf{p}}\right)$ na temperatura média da pá

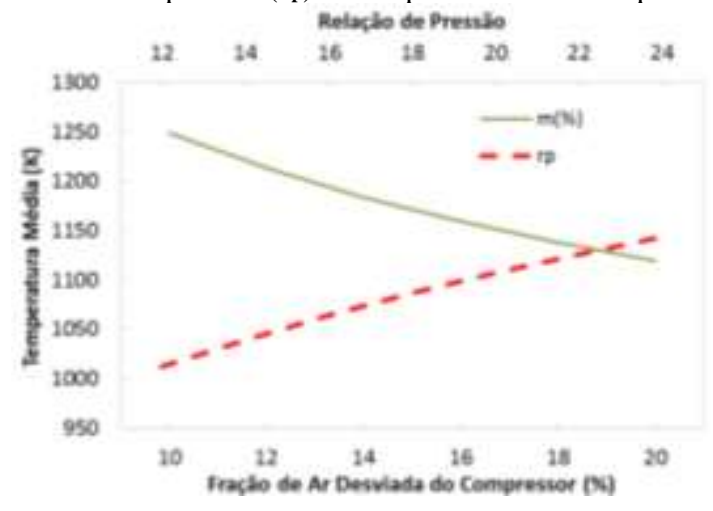

Fonte: Autores, 2018.

Figura 3 - Efeito da fração de ar desviada do compressor (m) e da razão de pressão $\left(\mathbf{r}_{\mathbf{p}}\right)$ na temperatura máxima da pá

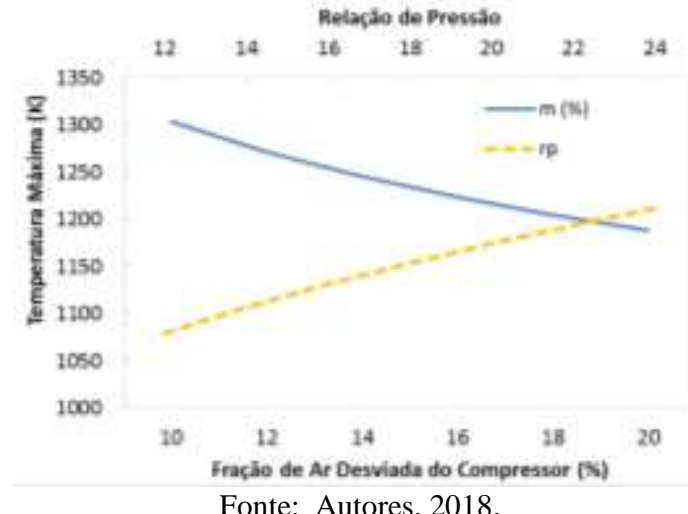

Figura 4 - Efeito da fração de ar desviada do compressor (m) e da razão de pressão $\left(\mathbf{r}_{\mathbf{p}}\right)$ no calor removido da pá $\left(\mathbf{q}^{\mathbf{9}}\right)$.

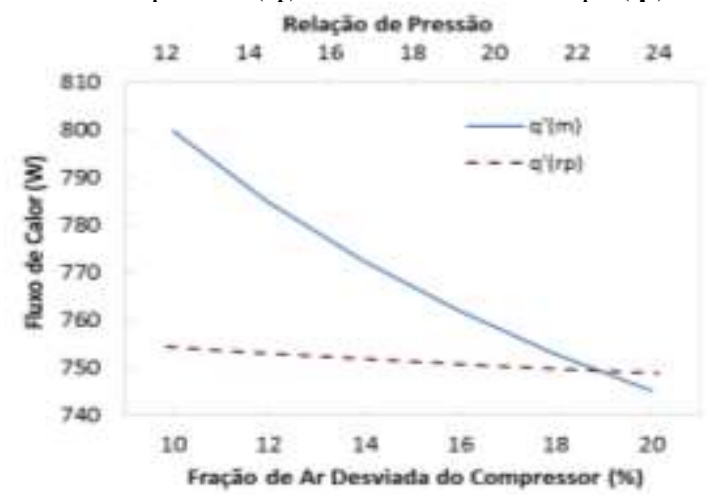

Fonte: Autores, 2018.

No que tange ao fluxo de calor removido da pá, tanto na análise da extração de ar do compressor como na razão de pressão, verificou-se um decréscimo no fluxo de calor. Analisando o calor removido da pá, em relação à variação da razão de pressão, observa-se que a temperatura do fluido de resfriamento $\mathrm{T}_{2}$ aumenta consoante ao aumento da razão de 
pressão, que por consequência eleva a temperatura da pá, submetendo-a a uma maior exigência térmica. Na análise da variação do calor removido em relação à fração de ar desviada do compressor, apesar da temperatura advinda da saída do compressor ser constante, a temperatura da pá é reduzida, devido ao aumento do ar desviado para resfriamento. Desse modo, a diferença entre eles torna-se cada vez menor, o que resulta no decréscimo da taxa de transferência de calor, conforme verificado na Fig. 4.

Figura 5 - Gradiente de temperatura na pá da turbina a gás em função da vazão de ar extraída: (a)-10\%; (b)-15\% e (c)-20\%

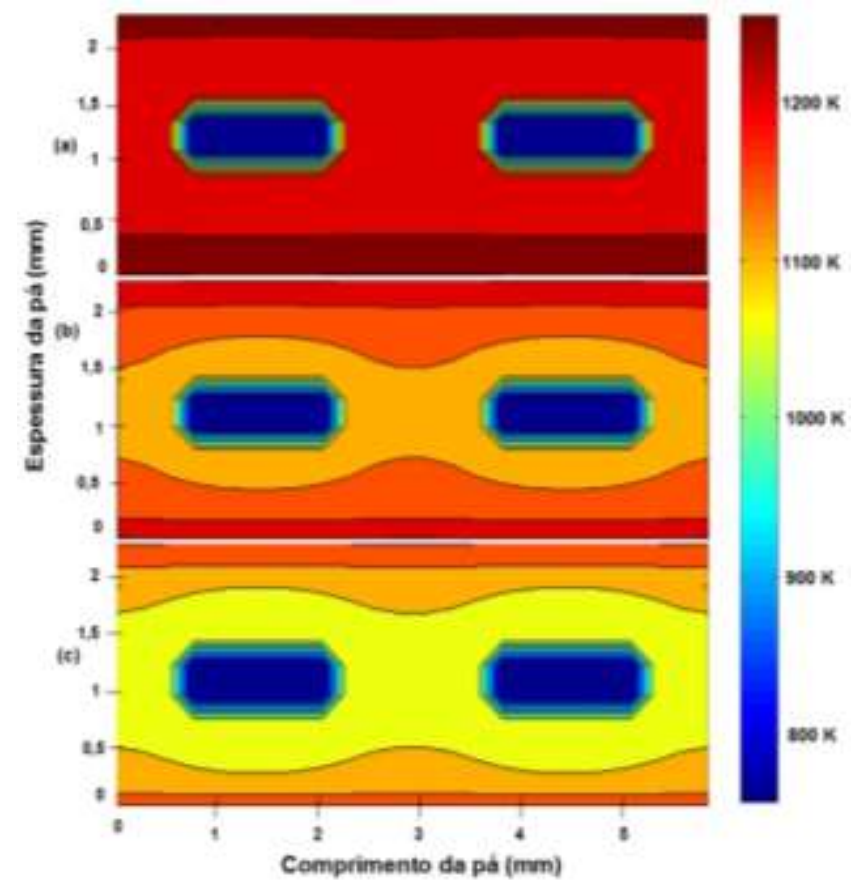

Fonte: Autores, 2018.

Figura 6 - Gradiente de temperatura da pá da turbina a gás em função da razão de pressão: (d)-12; (e)-18 e (f)-24

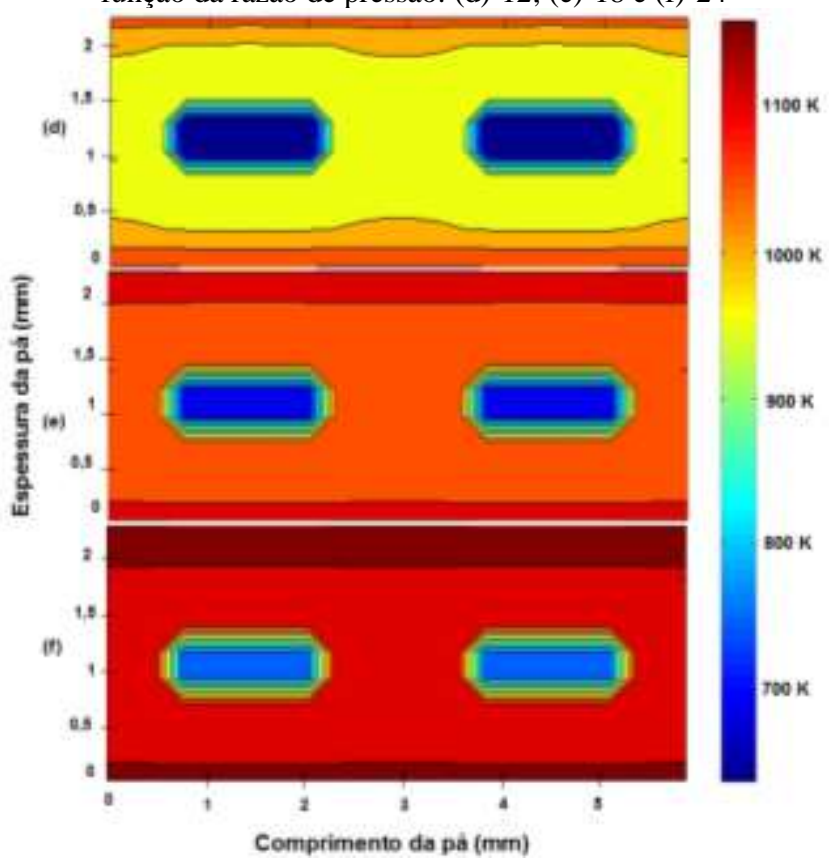

Fonte: Autores, 2018.

A Fig.5 representa o gradiente de temperatura na pá da turbina para uma relação de pressão de 22,4 e diferentes valores de fração de ar de resfriamento. Observa-se, no interior da pá, que para maiores valores de vazão de resfriamento as solicitações térmicas da pá serão menores. Menores gradientes de temperatura na pá geram menos variações de propriedades no interior do material e evita níveis de dilatação distintos em uma mesma região, evitando assim possíveis trincas, fadiga térmica, deformações localizadas, dentre outros problemas, conforme constatados por Sahith et al. (2018) e Ersayin e Ozgener (2015).

A Fig. 6 representa o gradiente de temperatura da pá para diferentes valores de razão de pressão, e com valor fixo de $18,87 \%$ de vazão de ar de resfriamento desviada do compressor. Os resultados evidenciam que maiores valores de razão de pressão geram maior solicitação do material da pá. Assim, deve ser analisado o custo benefício de se utilizar altos valores de $r p$ e obter maior eficiência operacional e potência desenvolvida, porém exigindo-se maiores custos de manutenção e troca de peças, devido o menor tempo de vida útil dos elementos da turbina. Vale ressaltar, conforme apresentado por Wan et al. (2018), que os custos de manutenção em turbinas a gás devem ser minimizados pois determinam se uma instalação será ou não eficiente energeticamente. Deve-se ainda salientar que caso não houvesse a vazão de resfriamento de $18,87 \%$ para tais gradientes, as temperaturas alcançadas no material seriam ainda maiores, conforme indicado nas Fig. 2 e Fig. 3 para as curvas de $r p$, o que evidencia a vantagem do resfriamento interno da pá como apresentado por Xu et al., 2015.

\section{CONCLUSÃO}

Como visto através da modelagem feita neste estudo, uma variação de $10 \%$ a $20 \%$ no desvio de ar da saída do compressor, embora possa diminuir a potência desenvolvida pela turbina, acarretará em uma variação de temperatura média da pá da turbina de até $130 \mathrm{~K}$, o que leva esse elemento a ter uma maior vida útil. Sendo esse fato um incentivo para que os fabricantes de turbina a gás fortaleçam as pesquisas em desenvolvimento e criação de tecnologias de resfriamento de pás de turbinas a gás, de modo a obter maiores taxas de resfriamento sem sacrificar o desempenho energético do equipamento. Observou-se ainda que para valores de razão de pressão maiores a eficiência termodinâmica da turbina aumenta, mas, em desvantagem, os gradientes térmicos da pá podem ser acentuados em mais de $110 \mathrm{~K}$, o que não é almejável do ponto de vista da manutenção e vida útil em operação. Em turbinas em operação é comum observar que o trabalho líquido do ciclo aumenta com a razão de pressão, atinge um máximo e em seguida começa a diminuir, o que pode ser explicado pelos resultados obtidos nesse trabalho.

A precisão da solução por diferenças finitas, utilizada neste estudo, pode ser melhorada pelo refinamento da rede utilizada, reduzindo os valores dos espaçamentos e aumentando o número de temperaturas nodais conhecidas. Em trabalhos futuros pode-se ainda analisar a influência das condições de entrada do ar e do tipo de combustível utilizado nas temperaturas atingidas na pá da turbina.

\section{REFERÊNCIAS}

AHMADI, P.; DINCER, I.; ROSEN, M. A. Thermodynamic modeling and multi-objective evolutionary-based optimization of a new multigeneration energy system. Energy Conversion and Management, vol. 76, p. 282-300, 2013. 
ASL, A. Z.; RAMEZANLOU, M. T. Thermo-mechanical behavior of gas turbine blade equipped with cooling ducts and protective coating with different thicknesses. International Journal of Mechanical Sciences, vol. 150, p. 656-664, 2019.

BUNKER, R. S. Cooling Design Analysis. The Gas Turbine Handbook, p. 295-309. 2006.

COHEN, H.; ROGERS, G. F. C., SARAVANAMUTTOO, H. I. H. Gás turbine theory. 4. ed. 1996.

DAVIS, D.Y.; STERANS E.M., Flight Propulsion System Final Design and Analysis, 1985, NASA CR-168219.

DU, K.; LI, Z.; LI, J.; SUNDEN, B. Influences of a multicavity tip on the blade tip and the over tip casing aerothermal performance in a high pressure turbine cascade. Applied Thermal Engineering, vol. 147, p. 347-360, 2019.

ERSAYIN, E.; OZGENER, L. Performance analysis of combined cycle power plants: A case study. Renewable and Sustainable Energy Reviews, vol. 43, p. 832-842, 2015.

FAN, X.; LI, L.; ZOU, J.; WANG, J.; WU, F. Local heat transfer of vortex cooling with multiple tangential nozzles in a gas turbine blade leading edge cooling passage. International Journal of Heat and Mass Transfer, vol. 126 (B), p. 377-389, 2018.

FRĄCKOWIAK, A.; WOLFERSDORF J., CIAŁKOWSKI, M. Optimization of cooling of gas turbine blades with channels filled with porous material. International Journal of Thermal Sciences, vol. 136, p. 370-378, 2019.

HALILA, E.E., LENAHAN, D.T., and THOMAS, T.T. Energy Efficient Engine High Pressure Turbine Test Hardware: Detailed Design Report, 1982, NASA CR167955 .

INCROPERA, F. P.; DE WITT, D. P.; BERGMAN, T. Fundamentos de transferência de calor e massa. 6. ed. Rio de Janeiro: LTC, 2007. 643 p.

LI, H; HAN, F; WANG, H; ZHOU, Z; TAO, Z. Film cooling characteristics on the leading edge of a rotating turbine blade with various mainstream Reynolds numbers and coolant densities. International Journal of Heat and Mass Transfer, vol. 127(B), p. 833-846, 2018.

MEMON, A. G.; HARIJAN, K.; UQAILI, M. A.; MEMON, R. A. Thermo-environmental and economic analysis of simple and regenerative gas turbine cycles with regression modeling and optimization. Energy Conversion and Management, vol.76, p. 852-864, 2013.

MERONI, A; ROBERTSON, M; MARTINEZ-BOTAS, R; HAGLIND, F. A methodology for the preliminary design and performance prediction of high-pressure ratio radial-inflow turbines. Energy, vol. 164, p. 1062-1078, 2018.

MORAN, M. J; SHAPIRO, H. N. Princípios de termodinâmica para engenharia. 7. ed. Rio de Janeiro: LTC, 2013.

SABOOHI, Z.; OMMI, F.; AKBARI, M. Multi-objective optimization approach toward conceptual design of gas turbine combustor. Applied Thermal Engineering, vol. 148, p. 1210-1223, 2019.
SAHITH, M. S.; GIRIDHARA, G; SURESH KUMAR, R. Development and analysis of thermal barrier coatings on gas turbine blades - A Review. Materials Today: Proceedings, vol. 5, Issue 1, Part 3, p. 2746-2751, 2018.

SALPINGIDOU, C. Analysis of turbine blade cooling effect on recuperative gas turbines cycles performance. Energy, vol. 164, p 1271-1285, 2018.

SANJAY, S. M. Energy and exergy analysis of air-film cooled gas turbine cycle: Effect of radiative heat transfer on blade coolant requirement. Applied Thermal Engineering, vol. 129, p. 1403-1413, 2018.

SCIUBBA, E. Air-cooled gas turbine cycles - Part 1: An analytical method for the preliminary assessment of blade cooling flow rates. Energy, vol. 83, p. 104-114, 2015.

SUNDBERG, J. Heat Transfer Correlations for Gas Turbine Cooling. 2006. 89 f. Dissertação (Mestrado) - Curso de Engenharia Mecânica, Linköping University, Linköping, 2006.

TORRES, A. M. D. Effect of ideal gas model with temperature-independent heat capacities on thermodynamic and performance analysis of open-cycle gas turbines. Energy Conversion and Management, vol. 176, p. 256-273, 2018.

WAN, A.; GU, F.; CHEN, J.; ZHENG, L.; HALL, P.; JI, Y.; GU, X. Prognostics of gas turbine: A condition-based maintenance approach based on multi-environmental time similarity. Mechanical Systems and Signal Processing, vol. 109, p. 150-165, 2018.

WANG, W. Efficiency study of a gas turbine guide vane with a newly designed combined cooling structure. International Journal of Heat and Mass Transfer, vol. 80, p. 217-226, 2015.

WENTONG, S.; WEILIN, Y.; LUCHENG J. Effect of inlet total pressure non-uniform distribution on aerodynamic performance and flow field turbine. International Journal of Mechanical Sciences, vol. 148, p. 714-729, 2018.

XU, L; BO, S; HONGDE, Y; LEI, W. Evolution of Rollsroyce Air-cooled Turbine Blades and Feature Analysis. Procedia Engineering, vol. 99, p. 1482-1491, 2015.

ZENG, L; CHEN, P; LI, X.; REN, J.; JIANG, H. Influence of simplifications of blade in gas turbine on film cooling performance. Applied Thermal Engineering, vol. 128, p. 877-886, 2018.

ZHOU, J; WANG, X; LI, J; LI, Y. Effects of film cooling hole locations on flow and heat transfer characteristics of impingement/effusion cooling at turbine blade leading edge. International Journal of Heat and Mass Transfer, vol. 126, (B), p. 192-205, 2018.

\section{COPYRIGHT}

Direitos autorais: Os autores são os únicos responsáveis pelo material incluído no artigo.

Submetido em: 10/11/2018 Aprovado em: 12/12/2018 


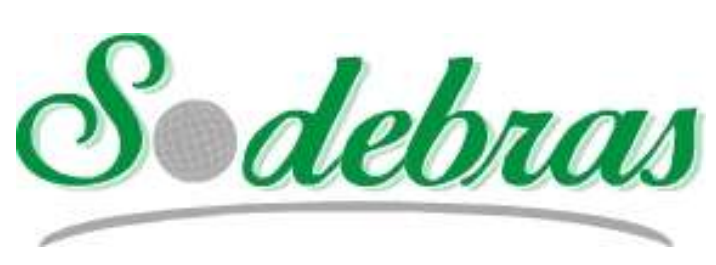

\author{
Revista SODEBRAS - Volume 14 \\ $\mathrm{N}^{\circ} 157$ - JANEIRO/ 2019
}

\title{
ANTROPOMETRIA E ERGONOMIA COMO FERRAMENTAS DE VANGUARDA PRODUTIVAS NAS INDÚSTRIAS DO FUTURO
}

\author{
ERGONOMICS AND ANTHROPOMETRY AS PRODUCTION \\ VANGUARD TOOLS IN THE INDUSTRIES OF THE FUTURE
}

\author{
NATASHA MARTINS RODRIGUES DE JESUS ${ }^{1}$; RAFAEL SOARES SOUZA ${ }^{1}$; \\ ROQUE ANTÔNIO MOURA ${ }^{1}$ \\ 1 - FACULDADE DE TECNOLOGIA DE SÃO JOSÉ DOS CAMPOS - PROFESSOR JESSEN VIDAL \\ natashamartinsj@outlook.com; rsoares1995@gmail.com; roque.moura@fatec.sp.gov.br
}

\begin{abstract}
Resumo - A ergonomia e a antropometria por desconhecimento, não são utilizadas preventivamente contra doenças profissionais como a lesão por esforço repetitivo e o distúrbio osteomuscular relativo ao trabalho. Nesse sentido, quantificar e apresentar uma solução com base na biomecânica e na força dos músculos tornase essencial, para preservação da saúde humana. Portanto o objetivo deste trabalho é durante as atividades laborais do dia a dia apresentarem uma solução que evite inflamação e avaria nos músculos do antebraço e das mãos. $O$ método utilizado é através da programação de movimentos respeitando a diferença de trabalho entre os gêneros masculino e feminino, com aplicação técnica na solução do problema, dentro do eixo tecnológico e científico. $O$ resultado indica haver diferença significativa entre os gêneros, concluindo pelo uso e adequações simultâneas da ergonômica e antropometria.
\end{abstract}

Palavras-chave: Antopometria. Ergonomia. Músculos. Doenças profissionais.

\begin{abstract}
Ergonomics and anthropometry due to lack of knowledge are not used preventively against occupational diseases such as repetitive effort injury and musculoskeletal disorders. Thus, quantifying and presenting a solution based on biomechanics and strength of the senses becomes essential for the preservation of human health. Therefore, this study aims work activities at day-to-day, presenting a solution that avoids inflammation and damage in the muscles of the forearm and hands. The method used programed movements at work, respecting differences between the male and female genders, with technical application in the solution of the problem, within the technological and scientific axis. The result indicates that there is a significant difference between the genders, concluding for the appropriate and simultaneous use of ergonomics and anthropometry.
\end{abstract}

Keywords: Anthropometry. Ergonomics. Muscles. Occupational diseases.

\section{INTRODUÇÃO}

Buscando aumentar o conhecimento e entendimento sobre os efeitos da técnica da ergonomia e antropometria, tornou-se oportuno a necessidade de um trabalho claro e com embasamento técnico e científico. Dentre os benefícios de se adotar um posto de trabalho antropometricamente e ergonomicamente correto, está à melhora na motivação e comprometimento dos empregados, normalização da função muscular e do esforço biomecânico durante a atividade de montagem (AMADIO e SERRÃO, 2011).

\section{1 - Ergonomia}

A palavra ergonomia deriva do grego Ergon (Trabalho) e Nomos (Normas, regras), consistindo de uma abordagem sistêmica de todos os aspectos da atividade humana. A ergonomia é um estudo que se trata principalmente do bem-estar do empregado, visando ambientes com maior segurança, ou seja, que evitem problemas graves aos mesmos por necessidade de repetição da tarefa, como LER (Lesão por Esforço Repetitivo), DORT (Distúrbio Osteomuscular Relacionado ao Trabalho), entre outros problemas encontrados. A ergonomia tem sua obrigatoriedade legal e parâmetros ditada pela norma regulamentadora número 17 (IIDA, 2005).

A ergonomia originou com estudos e pesquisas na área da fisiologia do trabalho, especificamente em estudar fatores que causavam a fadiga no trabalho e no consumo energético provocado pelo mesmo, visando buscar soluções para tais problemas, fisiologistas e psicólogos tinham o objetivo de colaborar no setor industrial, para que a produção fosse aumentada sem adoentar os empregados e a Figura 1, ilustra um exemplo da postura correta no desenvolvimento da atividade laboral (AMADIO e SERRÃO, 2011).

Figura 1 - Ergonomia correta na atividade laboral

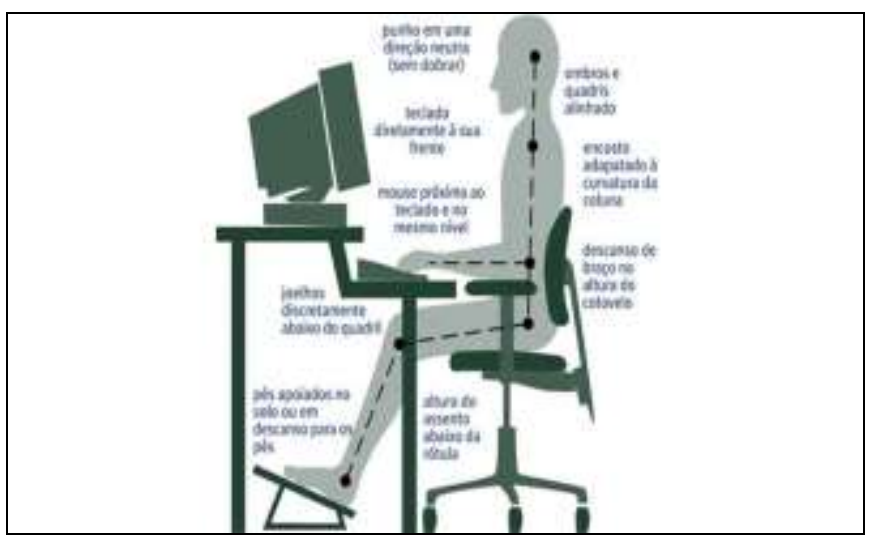

Fonte: Blog da Folha Universitária Online, 2014. 


\section{2 - Antopometria}

Segundo Quételet (2001), a antropometria teve origem na sociedade egípcia e grega e é compreendida como a ciência da qual a ergonomia utiliza as medidas corporais e as medidas dos instrumentos de trabalho para proporcionar conforto e saúde ao trabalhador, adequando às medidas do corpo humano conforme Figura 2.

Figura 2 - Antropometria e raios de alcance dos membros superiores

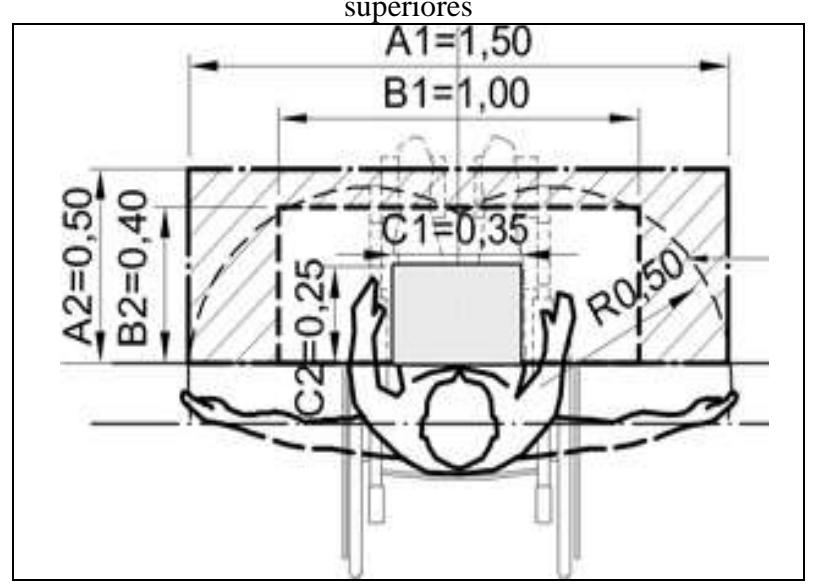

Fonte: Acessibilidade, 2014.

As medidas do corpo humano estão diretamente envolvidas ao alcance dos movimentos do corpo humano e as posturas adotadas no ambiente de trabalho, pois, a importância das medidas (Figura 2) ganhou especial interesse na década de 40 , quando iniciou a produção em massa e seriada para se observar a saúde e postura dos trabalhadores (KROEMER e GRANDJEAN, 2005; QUÉTELET, 2001).

Uma das mais importantes aplicabilidades das medidas antropométricas na ergonomia é no dimensionamento do posto de trabalho, local onde se realizará os movimentos laborais. Há dois estudos antropométricos, o estudo antropométrico estático e o dinâmico. Este trabalho prevê um estudo sobre a antropometria dinâmica (Figura 2), considerando as medidas dos segmentos corporais em movimento (TURCONI et al., 2006).

\section{3 - Posto de Trabalho}

Posto de trabalho é o espaço laboral onde se realiza uma atividade laboral. Entretanto, em alguns trabalhos, não há um lugar específico para efetuar as tarefas e, portanto, posto de trabalho se refere à própria atividade. Independente de atividades na administração ou chão de fábrica, em um recinto específico há a necessidade de lugares que estejam habilitados e em reais condições para exercer a profissão. A legislação trabalhista obriga que o posto de trabalho esteja em perfeitas condições de segurança e higiene. Em uma visão holística, esses aspectos são importantes tanto para o empregado como para o empregador (BRASIL, 2018).

$\mathrm{O}$ design do posto de trabalho precisa ser ergonômico na medida em que os conhecimentos científicos relativos ao homem são utilizados na concepção, com vistas a reduzir a fadiga física, facilitar a operação dos equipamentos e instrumentos, proporcionando segurança e conforto para os empregados atingindo uma produtividade eficaz, pois o trabalho é a finalidade primeira da ação ergonômica, e o que o ergonomistas deve prever, é uma concepção de situações de trabalho que não alterem a saúde dos trabalhadores
(Figura 3) e nas quais estes possam exercer suas competências, ao mesmo tempo num plano individual $\mathrm{e}$ coletivo, e encontrar possibilidade de valorização de suas capacidades, alcançando os objetivos econômicos determinados pela empresa, em função dos investimentos realizados ou futuros (KROEMER e GRANDJEAN, 2005).

A origem do posto de trabalho remonta na história moderna, com os resultados da Revolução Industrial e a criação de fábricas ou indústrias que precisavam de mão de obra diferentemente do que acontecia com as grandes oficinas ou inclusive com o trabalho rural (BOUYER, 2007).

Figura 3 - Atividade laboral no posto de trabalho

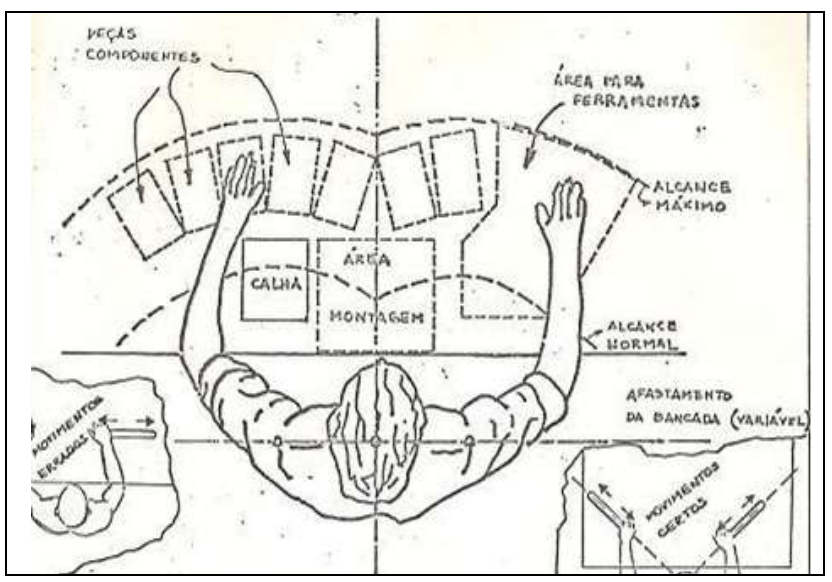

Fonte: As técnicas e atividades do sistema de gestão Lean, 2009.

Segundo Bouyer (2007), na concepção de quatro premissas que conceituam a maturidade de um discurso técnico-científico, como a positividade, epistemologização ou teoria do conhecimento, cientificidade e formalização, define a ergonomia e a situa entre o limiar da epistemologização e o da cientificidade, ou seja, a caracterização da ergonomia como ciência encontra-se confusa, porém os empregadores estão cientes da necessidade da interdisciplinaridade na construção da ergonomia científica e não reducionista, pois o conforto mínimo do empregado, no trabalho em pé ou sentado (Figura 4), resulta em um relativo aumento da produtividade.

Figura 4 - Atividade laboral em pé e sentado

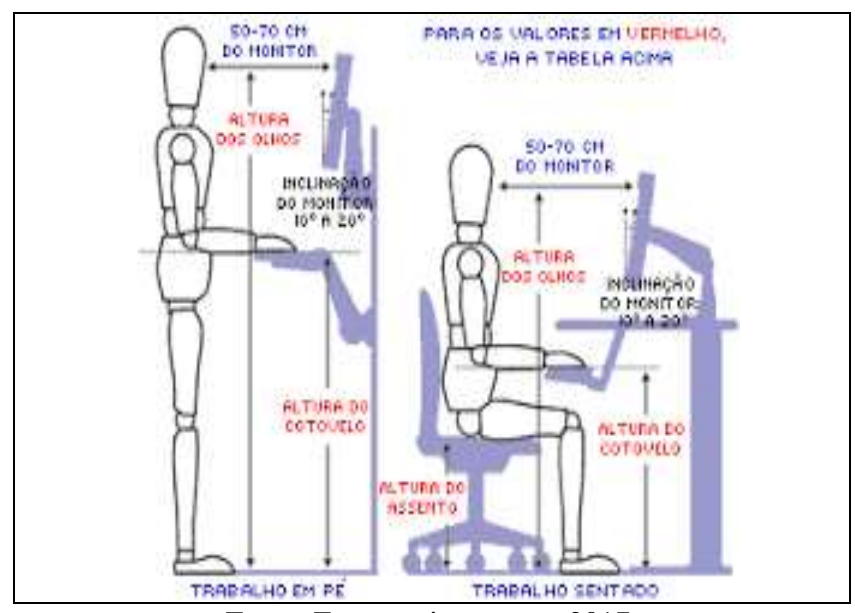

Fonte: Ergonomic posture, 2017.

A ergonomia não é só análise da atividade de pé ou sentado, mas sim, a análise de toda atividade onde pode ser utilizada mesmo em outros domínios que não o do trabalho. 
Os aspectos chave da ergonomia, como desenvolvimento da ação postural e comportamental, o papel socioeconômico do ergonomista e sua interação entre o aumento do conhecimento consciente executando a atividade corretamente, é o fator chave para a transformação da situação do trabalho no Brasil, sendo um método cíclico que se realimenta do conhecimento ou aumento da consciência gerado na realização do trabalho (MONTMOLLIN, 2007).

\section{METODOLOGIA}

O método deste trabalho traz uma visão sucinta da situação ergonômica e antropométrica em ação, cuja definição não é tão difundida, pois primeiro o que deveria ser um processo natural, assim não se apresenta, haja vista que muitos empregadores não conhecem como deveriam o conceito antropométrico-ergonômico e segundo, porque os empregados quando expostos em uma situação de desconforto, muitos se inibem por receio ou negligência em solicitar as devidas adequações antropométricas e ergonômicas em seus postos de trabalho.

A metodologia empregada neste trabalho foi uma revisão da origem histórica e bibliográfica do método da ergonômica e antropometria dinâmica, elencando sugestões para diversas situações e definições que podem ser desconhecidos ora pelo empregador por razões econômicas, ora pelo empregado por receio ou incerteza, mas nunca, simultaneamente ou cumulativamente por ambos.

Um posto de trabalho deve ser projetado de forma que permita aos trabalhadores, uma sensação de conforto e bemestar durante a execução de suas atividades operacionais e, portanto, criando uma percepção de usar menos força para executar um esforço, ou seja, disponibilizando toda facilidade com redução de movimentação e intensidade dos esforços, e dessa forma prevenindo doenças profissionais como a LER e a DORT.

Finalmente um posto de trabalho não deve ser um limitador para gêneros masculino e feminino, pois ambos executarão sua operação dentro do takt time previsto e com a qualidade requerida. A identificação dos movimentos desnecessários e lesivos ao empregado, precisa partir das pessoas com a finalidade de melhorá-la, reduzindo-a ou a eliminando. Porém isso gera uma abordagem operacional e investigativa, com a necessária fundamentação teórica, gerando entre teoria e prática a validade científica deste trabalho, apontando um posto de trabalho conceitual conforme demonstrado na Figura 5.

Figura 5 - Protótipo meramente ilustrativa de um posto de trabalho enxuto e sem desperdícios

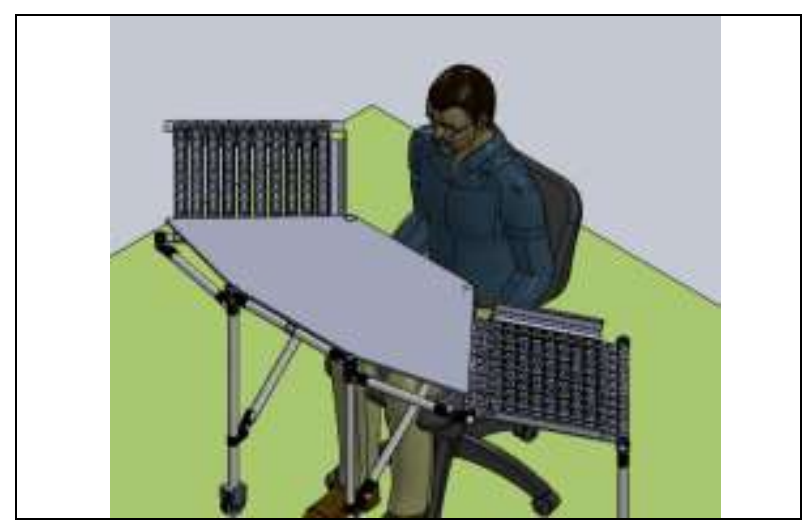

Fonte: Autores, 2016.
Conforme demonstrado na Figura 5, um posto de trabalho com formato de bancada "meia cana", lembra um cockpit de avião ou o cockpit de um carro das competições de fórmula um, com características de abraçar e dar conforto ao trabalhador, com ferramentas e peças ao alcance de suas mãos.

Em um posto de trabalho deve ser racional, lógico, leve e enxuto, mas confeccionado sobre uma base de material maciço, onde ficará à disposição dos materiais e apoio do trabalhador, revestido com uma manta de borracha ou Neoprene, que tem boa absorção aos impactos inerentes ao processo, protegendo de forma visual, funcional e durável o posto de trabalho.

As duas rampas, uma para receber os insumos e outra para escoar a produção conterão identificação do produto, gabarito de qualidade "go ou no go", para melhor organização e qualidade do trabalho.

Os roletes acoplados nas rampas, permitirão que o material ser deslocado de uma maneira mais eficiente com o deslizamento dos materiais a serem trabalhados evitando que o operador empregue esforços repetitivos de arrastar ou empurrar durante sua atividade laboral.

Um painel fixado e ergonomicamente adaptado fará o acondicionamento das ferramentas e materiais sobressalentes necessárias para a operação de montagem.

Finalmente uma cadeira com ajuste de assento e encosto, de material compósito, tornará flexível e ajustável o posto de trabalho para os diferentes empregados e turnos de produção.

\section{RESULTADOS}

O conceito do antropométrico-ergonômico de um posto de trabalho conforme o proposto será flexível para qualquer área produtiva inclusive nas atividades com interação homem-máquina.

A utilização da bancada como conceito metodológico, será abrangente pelo fato de sua simplicidade com a característica de ser ajustável dentro das especificações e particularidade da operação fabril, podendo realizar funções desde montagens simples até as mais complexas como, por exemplo, montagem de motores, computadores e celulares.

Quando o empregado realiza suas atividades com mais conforto, demonstra-se comprometido e sente-se estimulado e reconhecido, produzindo mais e melhor.

\section{CONCLUSÃO}

Conclui-se que para a execução de uma atividade laboral ergonomicamente e antropometricamente corretas e efetivas, os ergonomistas necessitam ter uma visão ampliada do setor de trabalho e de seus produtos, ou seja, devem avaliar os aspectos físicos, cognitivos e organizacionais.

É notório que a ergonomia e a antropometria estão diretamente relacionadas ao orçamento da empresa, pois empregados desenvolvendo suas atividades laborais em um posto de trabalho desconfortável e fora da filosofia de eliminar desperdícios, certamente aumenta o absenteísmo por falta de comprometimento e há uma probabilidade de ocorrer acidentes, e dessa forma gerará gastos adicionais e inesperados, onerando todo o controle financeiro empresarial. 


\section{REFERÊNCIAS}

AMADIO A. C.; SERRÃO JC. A Biomecânica em Educação Física e Esporte. São Paulo, Escola de Educação Física e Esporte - USP, 2011.

BOUYER, G. C. A ciência ergonômica entre a epistemologização e a cientificidade. In: Encontro Nacional de Engenharia de Produção, 27, 2007, Foz do Iguaçu. Anais. Foz do Iguaçu: PUC, 2007.

BRASIL. Ministério do Trabalho e Emprego. Disponível em> http://trabalho.gov.br/seguranca-e-saude-notrabalho/normatizacao/normas-regulamentadoras. Acesso em 11 set. 2018.

IIDA, I. Ergonomia: projeto e produção. 2.ed. rev. e ampl., São Paulo: Edgard Blucher, 2005.

KROEMER, K. H. E., GRANDJEAN, E. Manual de ergonomia: adaptando o trabalho ao homem. $5^{\text {a }}$ ed. Porto Alegre: Bookman, 2005.

MONTMOLLIN, M. Vocabulaire de l'Ergonomie. Tolouse, France: Octarès Editions, 2007.

QUÉTELET, A. Physique sociale. Antropométrie ou mesure des différentes facultés de l'homme. Bruxelles: C. Muquardt; 2001.

TURCONI G, GUARCELLO M, MACCARINI L, BAZZANO R, ZACCARDO A, ROGGI C. BMI values and other anthropometric and functional measurements as predictors of obesity in a selected group of adolescents. Eur J Nutr. 2006; 45(3):136-43.

\section{COPYRIGHT}

Direitos autorais: Os autores são os únicos responsáveis pelo material incluído no artigo. 